\title{
O INADIMPLEMENTO NA NOVA TEORIA CONTRATUAL: O INADIMPLEMENTO ANTECIPADO DO CONTRATO
}

Dissertação apresentada à Banca Examinadora do Programa de Pós-Graduação em Direito, da Faculdade de Direito da Universidade de São Paulo, como exigência parcial para obtenção do título de Mestre em Direito, na área de concentração de Direito Civil, sob orientação da Professora Titular Dra. Giselda Maria Fernandes Novaes Hironaka

\section{UNIVERSIDADE DE SÃO PAULO \\ FACULDADE DE DIREITO}

São Paulo - SP 
Autorizo a reprodução e divulgação parcial deste trabalho, por qualquer meio convencional ou eletrônico, para fins de estudo e pesquisa, desde que citada a fonte.

Catalogação da Publicação

Faculdade de Direito da Universidade de São Paulo

CUNHA, Raphael Augusto.

O Inadimplemento na Nova Teoria Contratual: O Inadimplemento Antecipado do Contrato / Raphael Augusto Cunha; orientadora Giselda Maria Fernandes Novaes Hironaka - São Paulo, 2015.

$295 \mathrm{f}$.

Dissertação (Mestrado) - Universidade de São Paulo, 2015.

I. Inadimplemento. II. Inadimplemento Antecipado do Contrato. III. O Inadimplemento na Nova Teoria Contratual 
CUNHA, Raphael Augusto

O Inadimplemento na Nova Teoria Contratual: O Inadimplemento Antecipado do Contrato

Dissertação apresentada à Faculdade de Direito da Universidade de São Paulo para obtenção do título de mestre

Aprovado em:

Banca examinadora:

\begin{tabular}{|l|l|}
\hline Prof. Dr. & Instituição \\
\hline Julgamento & Assinatura \\
\hline
\end{tabular}

\begin{tabular}{|l|l|}
\hline Prof. Dr. & Instituição \\
\hline Julgamento & Assinatura \\
\hline
\end{tabular}

\begin{tabular}{|l|l|}
\hline Prof. Dr. & Instituição \\
\hline Julgamento & Assinatura \\
\hline
\end{tabular}




\section{AGRADECIMENTOS}

À Faculdade de Direito da Universidade de São Paulo, que me propiciou oportunidade de crescimento profissional e pessoal;

À minha orientadora Giselda Maria Fernandes Novaes Hironaka, pelos aconselhamentos, sugestões e críticas, que muito auxiliaram no aperfeiçoamento deste trabalho;

Aos Professores Cláudio Luiz Bueno de Godoy e José Fernando Simão agradeço a minuciosa leitura crítica do texto e as valiosas sugestões formuladas durante a minha banca de qualificação;

Aos meus pais, por serem os alicerces de minha vida e a quem devo a minha eterna gratidão pela minha formação como ser humano e profissional e pelo constante incentivo de crescimento profissional e pessoal;

À Michelle Liang, pela compreensão pelas horas ausentes para a concretização desse estudo, pelo incentivo em meus projetos pessoais e profissionais e pelas leituras e sugestões realizadas;

À minha irmã, à minha avó e demais familiares e amigos pelo costumeiro apoio e carinho. 
"Se não fossem iguais, os homens não seriam capazes de compreender-se entre si e aos seus ancestrais, nem de prever as necessidades das gerações futuras. Se não fossem diferentes, os homens dispensariam o discurso ou a ação para se fazerem entender, pois com simples sinais e sons poderiam comunicar suas necessidades imediatas e idênticas. A pluralidade humana, afirma Hannah Arendt, tem esse duplo aspecto: o da igualdade e o da diferença." (Hannah Arendet, "A condição humana”, Ed. Forense Universitária, 1999, p. 188, inserido in "Danos à pessoa humana - Uma leitura civil-constitucional dos danos morais", Maria Celina Bodin de Moraes, Rio de Janeiro, Ed. Renovar, 2003, p. 76) 


\section{RESUMO}

CUNHA, Raphael Augusto. O Inadimplemento na Nova Teoria Contratual: $\mathrm{O}$ Inadimplemento Antecipado do Contrato. 2015, 295 f. Dissertação de Mestrado. Faculdade de Direito da Universidade de São Paulo. São Paulo, 2015.

Os institutos clássicos do direito das obrigações, notadamente os conceitos de obrigação, adimplemento e inadimplemento precisam ser relidos à luz dos valores da Constituição Federal de 1988 e dos princípios e das cláusulas gerais trazidos pelo Código Civil de 2002, em especial a boa-fé objetiva. A noção tradicional de obrigação, consubstanciada na ideia de uma submissão do devedor ao credor, vem sendo paulatinamente abandonada em favor de um novo conceito de relação obrigacional, composto por direitos e deveres recíprocos que convergem para a consecução de um objetivo comum: o adimplemento. Assim examinado, o adimplemento consiste em um processo dinâmico dentro do qual o devedor deve executar uma série de atos e observar inúmeros deveres (principais, secundários e laterais) necessários ao adimplemento. Foi diante dessa premissa que a doutrina moderna começou a sustentar que a infringência de deveres de conduta e de deveres anexos ao longo da relação obrigacional pode configurar um inadimplemento antecipado do contrato, que se refere às hipóteses em que o inadimplemento resta configurado a despeito de ainda não se ter atingido o termo contratual. Esse estudo visará analisar o conceito e demonstrar a necessidade da consolidação do inadimplemento antecipado como um mecanismo de proteção do credor, examinando a sua possibilidade de aplicação no direito brasileiro, os seus requisitos, a sua natureza jurídica, os seus limites e os seus efeitos.

Palavras-chave: Princípio da boa-fé objetiva. "Obrigação como processo". Adimplemento. Adimplemento Substancial. Inadimplemento. Inadimplemento Antecipado do Contrato. Efeitos do Inadimplemento Antecipado. Risco de descumprimento. 


\begin{abstract}
CUNHA, Raphael Augusto. Breach in the New Contractual Theory: The Anticipatory Breach of Contract. 2015, 295 f. Dissertação de Mestrado. Faculdade de Direito da Universidade de São Paulo. São Paulo, 2015.

The classic institutes of contract law, notably the concepts of obligation, performance and breach of contract need to be reread pursuant to the values of the Federal Constitution of 1988 and the principles and general clauses brought by the Civil Code of 2002, in special the good faith. The traditional notion of obligation, based on the idea of the debtor's submission to the creditor, has been gradually abandoned in favor of a new concept of obligatory relationship, composed of reciprocal rights and duties converging to achieve a common goal: performance. Thus, performance consists of a dynamic process in which the debtor must perform a series of acts and observe numerous duties (primary, secondary and lateral duties arising of good faith) necessary for performance. It was under this premise that modern legal scholars began to argue that any breach of duties along with the obligatory relationship can configure an anticipated breach of contract, which refers to cases in which the breach is affirmed before the contractual term. This essay aims to analyze the concept and demonstrate the need for consolidation of the anticipated breach as a creditor protection mechanism, examining its application possibility under Brazilian law, along with its requirements, legal status, limits and effects.
\end{abstract}

Keywords: Principle of Good Faith. "The obligation as a process". Performance. Substantial Performance. Breach of Contract. Anticipatory Breach of Contract. Effects of the Anticipatory Breach of Contract. Contract breach risk. 


\section{SUMÁRIO}

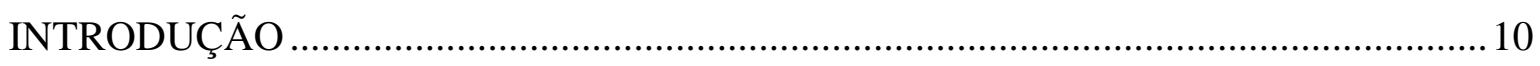

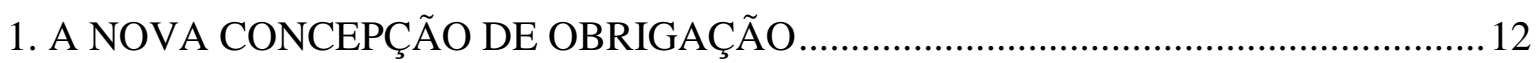

1.1. A necessária releitura do direito das obrigações....................................................... 12

1.2. A repercussão do princípio da boa-fé objetiva no âmbito do direito das obrigações 19

1.3. A alteração do conceito tradicional de obrigação: a obrigação como processo não apenas dirigido ao adimplemento da prestação principal ..................................................30

1.4. A funcionalização da relação obrigacional ................................................................36

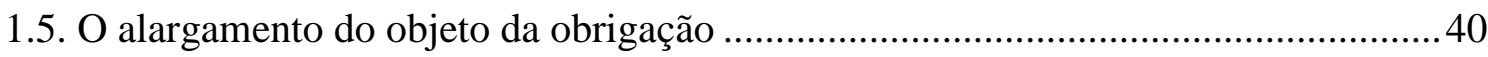

1.6. A alteração do conceito de adimplemento ................................................................. 46

1.7. O papel do credor na relação obrigacional e a sua importância para o adimplemento - os efeitos do inadimplemento do credor ………………….........................................5

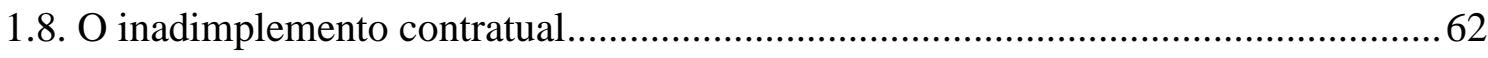

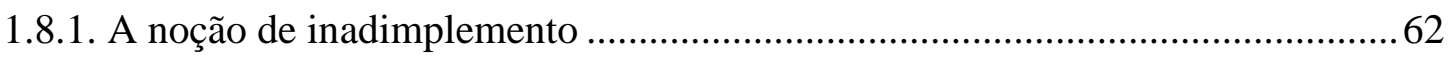

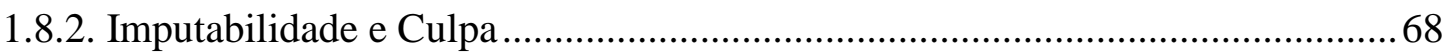

1.8.3. Modalidades de inadimplemento (classificação conforme os efeitos) ................76

1.8.4. Da desnecessidade da "violação positiva do contrato" como uma terceira modalidade de inadimplemento no direito brasileiro .................................................92

1.9. Os efeitos do inadimplemento, pelo credor, do dever de colaboração ..................... 108

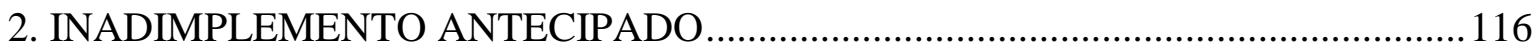

2.1. Considerações gerais sobre o inadimplemento antecipado.......................................116

2.2. $\mathrm{O}$ inadimplemento antecipado no direito estrangeiro e internacional ..................... 125

2.3. Inadimplemento antecipado: o conceito, a estrutura lógico-sistemática e os requisitos para a sua aplicação no direito brasileiro ………………………………...... 138

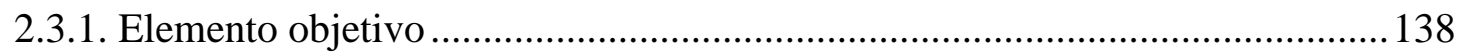

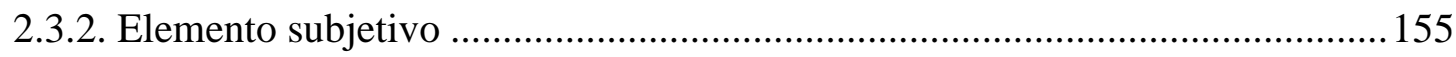

2.4. Distinção entre inadimplemento antecipado e risco de descumprimento da prestação

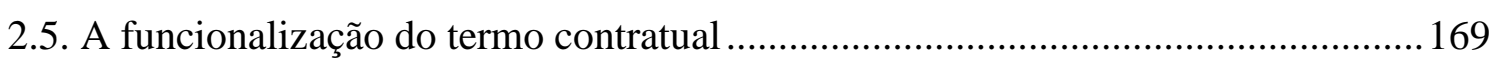

2.6. Natureza jurídica do inadimplemento antecipado ................................................. 176

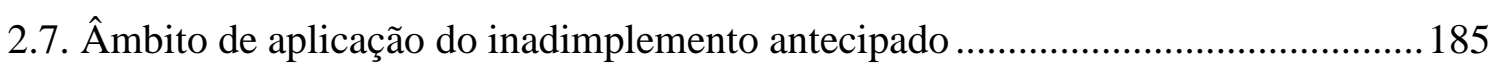

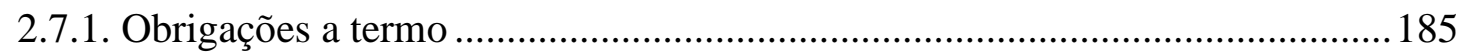


2.7.2. Contrato Preliminar

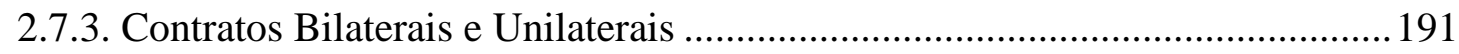

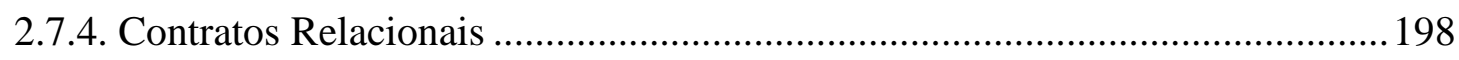

2.8. Limites para a aplicação do inadimplemento antecipado ....................................203

2.9. Inadimplemento antecipado do contrato imputável ao credor ..............................2 212

2.10. Há obrigatoriedade de se invocar o inadimplemento antecipado? ......................2216

3. EFEITOS DO INADIMPLEMENTO ANTECIPADO DO CONTRATO ..................226

3.1. Generalidades sobre os efeitos do inadimplemento antecipado do contrato ...........226

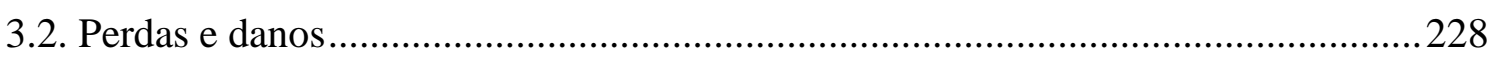

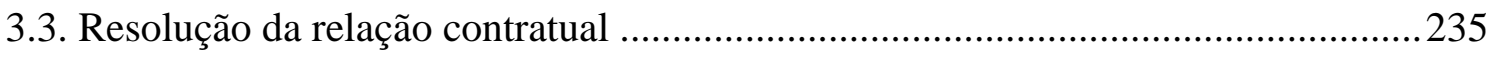

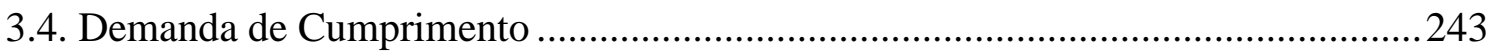

3.5. Efeitos do risco de descumprimento ("exceção de inseguridade")..........................248

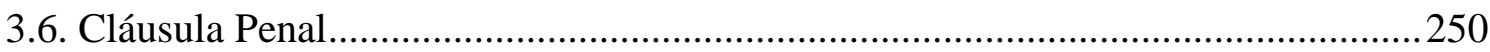

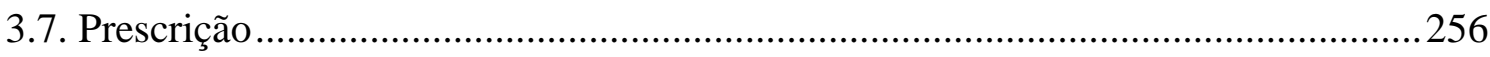

3.8. O inadimplemento antecipado na jurisprudência brasileira.................................2 264

3.8.1. Atraso na entrega de unidade de apartamento ...............................................2. 264

3.8.2. Prestação de serviços educacionais - curso de mestrado no exterior ...............266

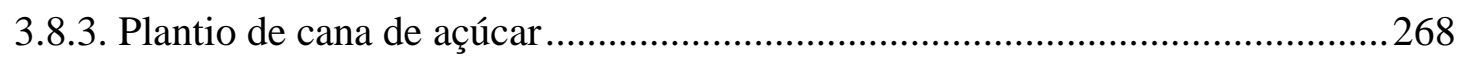

3.8.4. Contrato de compra e venda de quotas e fundo de comércio ...........................269

3.8.5. Contrato de compra e venda de mercadorias e licença gratuita de marca .......2270

3.8.6. Síntese conclusiva..................................................................................... 271

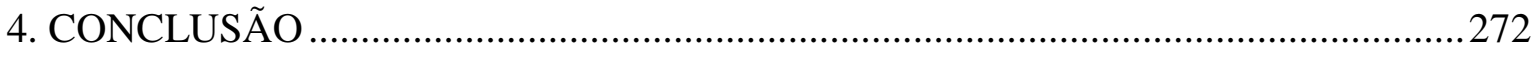

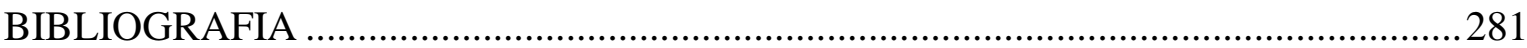




\section{INTRODUÇÃO}

Um dos ramos mais tradicionais do direito civil, com forte influência do direito romano, de onde herdou seus principais institutos, o direito das obrigações poderia parecer um verdadeiro âmbito de estagnação doutrinária, não oferecendo novos desafios e questionamentos ao jurista. Apenas à primeira vista, porém. Diante da Constituição Federal de 1988, que impregnou o direito civil de novos valores, e dos novos princípios que nortearam o Código Civil de 2002, tornou-se indispensável um novo exame e uma releitura funcional e axiológica de todos os institutos clássicos do direito das obrigações, notadamente dos conceitos de obrigação, adimplemento e inadimplemento.

À luz dessa premissa, esse estudo se destina a examinar a concepção atual de inadimplemento e, especialmente, a realizar uma análise crítica do chamado inadimplemento antecipado, que se refere a hipóteses em que o inadimplemento da prestação devida resta configurado, a despeito de ainda não se ter verificado o termo contratual. $\mathrm{O}$ instituto se apresenta como um importante mecanismo de proteção do credor diante de uma relação contratual incapaz de produzir os efeitos para a qual foi constituída, em virtude do já configurado inadimplemento do devedor.

Exigir que o credor se mantenha inerte diante de tal situação, aguardando o decurso do termo, revela apego a um formalismo e a uma visão estática do direito das obrigações que há muito tempo se abandonou. A atual concepção de obrigação, que foi profundamente modificada pelo princípio da boa-fé objetiva, permite ao credor agir imediatamente e requerer a tutela do ordenamento jurídico diante de uma hipótese de quebra antecipada do contrato.

Considerando o seu escopo, a presente investigação foi estruturada em torno de três eixos fundamentais, refletidos nos capítulos que seguem. No primeiro capítulo será realizado um exame de alguns institutos clássicos do direito das obrigações, a fim de relêlos a partir da atual concepção de obrigação, dinâmica, cooperativa e finalística; apenas a partir desta nova perspectiva da relação obrigacional é possível conceber a figura do inadimplemento antecipado no direito brasileiro. 
Em seguida, abre-se o segundo capítulo, que abordará os aspectos essenciais do inadimplemento antecipado. Serão examinados o conceito, a origem do instituto, o seu tratamento no direito estrangeiro e internacional e a sua recepção pelo direito brasileiro. Passa-se também ao exame dos elementos essenciais à caracterização do inadimplemento antecipado, dos pontos que o diferenciam de outros institutos jurídicos, da sua natureza jurídica e dos limites da sua aplicação.

O terceiro e último capítulo explorará quais os efeitos do inadimplemento antecipado do contrato, as possíveis consequências jurídicas dele decorrentes, bem como qual é a consequência mais adequada na hipótese de inadimplemento antecipado do contrato, se a resolução, a exigência de uma caução ou a propositura de uma demanda de cumprimento. Também serão estudadas as possíveis defesas substanciais a serem arguidas pelo devedor, a aplicabilidade da cláusula penal diante da quebra antecipada do contrato e se é possível falar em prazo prescricional para o credor ajuizar alguma medida judicial diante de uma situação de inadimplemento anterior ao termo. Por fim, será dedicado um item para examinar o posicionamento dos Tribunais brasileiros em relação ao instituto do inadimplemento antecipado.

Ao final, a presente dissertação se encerra com uma breve conclusão, que sintetiza o que foi analisado nas páginas que se seguem. 


\section{A NOVA CONCEPÇÃO DE OBRIGAÇÃO}

\subsection{A necessária releitura do direito das obrigações}

De maneira geral, costuma-se afirmar que o direito das obrigações ${ }^{1}$ é de "mais lenta evolução no tempo"2 e tende a se tornar menos mutável por estar fortemente atrelado a uma sólida tradição romanista $^{3}$, que se revelou hábil na formulação de categorias, definições e preceitos abstratos que são invocados pela doutrina até os dias de hoje $\mathrm{e}^{4}$. Assim, o direito das obrigações poderia sugerir, à primeira vista, um "verdadeiro âmbito de estagnação doutrinária", não oferecendo novos problemas e indagações aos seus estudiosos, o que não é verdade.

Apesar de o direito das obrigações ser menos "sensível às mutações sociais", ele não é imutável, "pois o Direito não deixa de ser a própria vida social normatizada, regulamentada por normas" e o "Direito não pode estatizar-se"6. Com efeito, o Direito é um produto cultural e modificável historicamente em decorrência das circunstâncias

${ }^{1}$ De acordo com Paulo Lôbo, "O direito das obrigações, na atualidade do sistema jurídico brasileiro, compreende as relações jurídicas de direito privado, de caráter pessoal, nas quais o titular do direito (credor) possa exigir o cumprimento do dever correlato de prestar, respondendo o sujeito do dever (devedor) com seu patrimônio. $\mathrm{O}$ direito das obrigações é o ramo do direito que regula a relação jurídica de dívida de prestação ou dever geral de conduta negocial entre pessoas determinadas ou determináveis, sendo este o núcleo que o identifica". LÔBO, Paulo. Direito civil: obrigações. 3. ed. São Paulo: Saraiva. 2013. p. 25.

${ }^{2}$ VARELA, João de Mattos Antunes. Das obrigações em geral. Coimbra: Almedina. 1970. p. 16.

${ }^{3}$ Nesse sentido, Giselda Hironaka pondera que: "A teoria geral das obrigações permanece estática, inerte, quase imutável, apesar do aumento do comércio jurídico (crescente pulverização das relações obrigacionais, segundo Venosa - p. 29 - e intensificação da atividade econômica, na expressão de Maria Helena Diniz - p. 4), dos impulsos de consumo estimulados pela propaganda e pela publicidade, e apesar, ainda, das novas tecnologias, como a internet, que cria formas novas de obrigação, mas que continuam a se reger pelas regras de antanho. Por quê?

Certamente o espírito prático dos juristas romanos contribuiu, em grande parte, para essa 'imutabilidade' posterior. Uma imutabilidade que não se impôs pela força, nem pela hierarquia, ou seja, uma imutabilidade que não teve de ser defendida pelo uso do poder, nem pela previsibilidade de rigidez do ordenamento jurídico obrigacional." HIRONAKA, Giselda Maria Fernandes Novaes. Direito das obrigações: o caráter de permanência dos seus institutos, as alterações produzidas pela lei civil brasileira de 2002 e a tutela das futuras gerações. In: DELGADO, Mário Luiz; Alves, Jones Figueirêdo (Coord.). Questões controvertidas no direito das obrigações e dos contratos. Série Grandes Temas de Direito Privado. v. 4. São Paulo: Método. 2005. p. 20.

${ }^{4}$ SCHREIBER, Anderson. A boa-fé objetiva e o adimplemento substancial. In: HIRONAKA, Giselda Maria Fernandes Novaes; TARTUCE, Flávio (Coord.). Direito contratual. Temas Atuais. São Paulo: Método. 2007. p. 125.

${ }^{5}$ FURTADO, Gabriel Rocha. Mora e inadimplemento substancial. São Paulo: Atlas, 2014. p. 1.

${ }^{6}$ AZEVEDO, Álvaro Villaça. Teoria geral das obrigações: responsabilidade civil. 10. ed. São Paulo: Atlas. 2004. p. 26. 
sociais, econômicas e temporais existentes em uma dada sociedade. Assim, o Direito - e não poderia ser diferente com o direito das obrigações - sofre os influxos e conforma a sociedade em cada período histórico, fazendo com que o jurista tenha que criar e reler os seus instrumentos e institutos para conferir conteúdo normativo a tal realidade e promover as modificações que se fizerem necessárias ${ }^{7}$. É sobre essa perspectiva que se analisará a mudança de paradigma pela qual o direito das obrigações passou.

O direito obrigacional do século XIX, tipificado no Código Francês de 1804, refletia com perfeição os quadros econômicos e sociais da época ${ }^{8}$, marcado pela ascensão da burguesia, revolução industrial, liberalismo econômico, livre concorrência e busca desenfreada pelo lucro. Para atender aos anseios da ideologia liberal dos séculos XVIII e XIX, o contrato foi idealizado como um instrumento jurídico capaz de promover a circulação de riquezas sem qualquer limite à vontade negocial e que servia a todos os tipos de relações e a qualquer pessoa, independentemente de sua posição.

Consoante observa Claudio Luiz Bueno de Godoy,

\begin{abstract}
À classe burguesa que ascendia, cuja atividade de produção alterava a índole agrária da economia da Idade Média, convinha a instrumentalização jurídica ou a ideologia mesmo da liberdade contratual, a absolutização, quase completa, da autonomia da vontade, quando revelada pela tríplice e intocável prerrogativa de escolher contratar, o que contratar e com quem contratar, de resto tanto quanto sucedia com o instituto da propriedade, longe de ser admitida como uma relação jurídica complexa, que impusesse também deveres ao proprietário e criasse direitos a centros de interesses opostos, não-proprietários. ${ }^{9}$
\end{abstract}

\footnotetext{
${ }^{7}$ Pietro Perlingieri destaca que "uma visão moderna, que queira analisar a realidade sem enclausurá-la em esquemas jurídicos formais, requer uma funcionalização dos institutos do direito civil que responda às escolhas de fundo operadas pelos Estados contemporâneos e, em particular, pelas suas Constituições. Dever do jurista, e especialmente do civilista, é 'reler' todo o sistema do código e das leis especiais à luz dos princípios constitucionais e comunitários, de forma a individuar uma nova ordem científica que não freie a aplicação do direito e seja mais aderente às escolhas de fundo da sociedade contemporânea. É necessário desancorar-se dos antigos dogmas, verificando sua relatividade e sua historicidade" PERLINGIERI, PIETRO. O direito civil na legalidade constitucional. Tradução de Maria Cristina De Cicco. Rio de Janeiro: Renovar. 2008. p. 137-138.

${ }^{8}$ Claudio Luiz Bueno de Godoy afirma que "a bem da verdade, e tal como sucede com qualquer instituto jurídico, que se coloca sempre em um contexto mais amplo, dos interesses e valores dele contemporâneos, numa dada sociedade, o contrato, na sua visão clássica, representava, no século XIX, exatamente o instrumento de afirmação econômica do estamento social então ascendente”. GODOY, Claudio Luiz Bueno de. Função social do contrato: os novos paradigmas contratuais. São Paulo: Saraiva. 2004. p. 4.

${ }^{9}$ GODOY, Claudio Luiz Bueno de. Função social do contrato: os novos paradigmas contratuais. São Paulo: Saraiva. 2004. p. 4.
} 
A concepção contratual clássica tinha como pressuposto que a justiça da relação contratual estava automaticamente garantida pelo fato das partes serem tidas como iguais, sob o aspecto formal ("todos são iguais perante a lei”), e que os direitos e deveres estabelecidos no contrato correspondiam à liberdade contratual e à vontade livre dos contratantes. $^{10}$

Nesse cenário, o direito das obrigações utilizou os princípios da autonomia da vontade $^{11}$, da força obrigatória dos contratos ${ }^{12}$ e da relatividade dos efeitos contratuais ${ }^{13}$, para legitimar - sob o ponto de vista jurídico - a celebração de contratos com quaisquer conteúdo e tipos de condições e obrigações, ainda que perversas e abusivas em relação às partes economicamente desfavorecidas ou com algum grau de dependência econômica ${ }^{14}$.

\footnotetext{
${ }^{10}$ Vale trazer as considerações de Judith Martins-Costa: "Ora, essa `vontade livre` e a igualdade eram a tradução jurídica da concepção econômica do liberalismo. A liberdade de iniciativa econômica que está na base do capitalismo, era a liberdade efetivamente perspectivada pelos autores do Código para derrubar, de uma vez por todas, os entraves ainda decorrentes do Ancien Régime à liberdade de circulação de mercadorias, impostos e privilégios feudais, pelas corporações, grêmios e monopólios fiscais. Vontade autônoma quer dizer autonomia como imunidade e como poder incidir sobre a realidade exterior quer dizer o asseguramento de um espaço contra o poder estatal, contra o que é heteronomia, frente ao Poder Público". COSTA, Judith Martins. A boa-fé no direito privado. São Paulo: Editora Revista dos Tribunais. 1999, p. 203.

${ }^{11}$ Segundo Orlando Gomes, o princípio da autonomia da vontade pode ser conceituado como o poder dos indivíduos de suscitar, mediante declaração de vontade, efeitos reconhecidos e tutelados pela ordem jurídica. Orlando Gomes entende que a liberdade de contratar manifesta-se de uma forma tríplice, abrangendo: (i) a liberdade de contratar propriamente dita, isto é, o poder atribuído às partes de suscitar os efeitos que pretendem, sem que a lei os imponha categoricamente; (ii) a liberdade de estipular o contrato, significando esta a faculdade de se vincular ou não a uma obrigação; e, por fim, (iii) a liberdade de determinar o conteúdo do contrato, estando as partes livres para manifestarem as suas vontades ao celebrarem o ajuste. No direito contratual clássico, o princípio da autonomia da vontade encontrava apenas um obstáculo, representado pelas regras imperativas que a lei formula e pela vedação da ofensa à ordem pública. Todavia, tais regras não eram comuns; ao contrário, eram bem poucas e se prestavam a proteger a vontade dos indivíduos. GOMES, Orlando. Contratos. Rio de Janeiro: Forense. 2008. p. 25 et seq.

${ }^{12}$ O princípio da força obrigatória dos contratos - "pacta sunt servanda" - estabelece que, uma vez que um contrato tenha sido celebrado com observância de todos os pressupostos e requisitos necessários à sua validade, deve ser executado pelas partes como se as suas disposições fossem preceitos legais imperativos. GOMES, Orlando. Contratos. Rio de Janeiro: Forense. 1995. p. 36.

${ }^{13}$ Segundo o princípio da relatividade dos efeitos dos contratos, os efeitos do contrato só atingem as partes que dele fazem parte, não aproveitando e nem prejudicando terceiros, em princípio. Portanto, somente as pessoas ligadas ao vínculo contratual são afetadas pelo conteúdo do contrato, de modo que a eficácia do contrato restringe-se aos contratantes, não atingindo aqueles alheios ao vínculo obrigacional.

${ }^{14}$ Aline Terra afirma que "tutelava-se o indivíduo, egoisticamente considerado, não como um fim em si mesmo, mas como meio de proteger a atividade por ele desenvolvida; instrumentalizava-se a tutela da pessoa à tutela do seu patrimônio, protegendo-se o indivíduo, tão-somente, enquanto sujeito de direito, sobretudo quando assumisse a posição de contratante ou proprietário. Identificava-se o sujeito quantitativamente. $\mathrm{O}$ direito civil se mostrava excludente, e deixava à sua margem um sem-número de indivíduos não-proprietários e não-contratantes, cuja existência ignorava-se". TERRA, Aline de Miranda Valverde. Inadimplemento anterior ao termo. Rio de Janeiro: Renovar. 2009. p. 11-12.
} 
Esse panorama, entretanto, começou a se modificar no final do século XIX, quando o acentuado desnivelamento social, resultante de um capitalismo unicamente pautado por critérios econômicos; as novas relações jurídicas massificadas ou coletivas decorrentes do aumento demográfico; as crises sociais decorrentes da $1^{\text {a }}$ Guerra Mundial, e as ideias socialistas expostas por Karl Marx fizeram com que parcela da doutrina começasse a defender uma releitura do direito das obrigações ${ }^{15}$.

Foi nesse contexto que os juristas se empenharam na criação de normas protetivas em novos ramos do direito público e privado (direito do trabalho, direito do consumidor etc.) e, no direito obrigacional, passaram a apoiar a invasão na autonomia da vontade para garantir o equilíbrio contratual e uma igualdade real entre as partes contratantes, bem como se preocuparam em incutir, no direito obrigacional, preocupações valorativas que, irradiadas dos textos constitucionais e legais, vieram impor solidarismo e eticidade nas relações privadas ${ }^{16}$.

Se no apogeu do liberalismo, como expressão da autonomia da vontade e da igualdade formal das partes, o contrato viabilizava as trocas comerciais e o capitalismo que consolidava, na sociedade contemporânea, passou-se a entender que o contrato também deve servir para cumprir os valores constitucionais e ser instrumento de promoção de igualdade substancial entre os contratantes, traduzida nas noções de justiça, equilíbrio e solidariedade, o que representa uma verdadeira mudança de paradigma no direito obrigacional. ${ }^{17}$ Com isso, surge a necessidade de se introduzir no direito civil conceitos

\footnotetext{
15 SCHLABENDORFF, Adriana. A reconstrução do direito contratual: o valor social do contrato. Tese de Mestrado. Junho de 2004.

${ }^{16}$ SCHREIBER, Anderson. A Boa-fé objetiva e o Adimplemento Substancial. In: HIRONAKA, Giselda Maria Fernandes Novaes; TARTUCE, Flávio (Coord.), Direito contratual. Temas Atuais. São Paulo: Método, 2007. p. 127.

${ }^{17}$ SALLES, Raquel Bellini de Oliveira. O desequilíbrio da relação obrigacional e a revisão dos contratos no Código de Defesa do Consumidor: para um cotejo com o Código Civil. In: Tepedino, Gustavo. Obrigações: estudos na perspectiva civil-constitucional. Rio de Janeiro: Renovar, 2005, p. 307. No mesmo sentido: “[...] o contrato deixa de ser somente a auto-regulamentação dos interesses das partes, a que subjacente determinada operação econômica que tencionam encetar, fazendo-as dotadas de uma liberdade intocável, porque exercida em pé de igualdade formal de iniciativa. Sobressaem, em novo paradigma, valores impostos pela concepção do Estado Social, de privilégio à igualdade real, ao equilíbrio das partes, tidas em verdadeira posição de cooperação, corolário do solidarismo, em que sua autonomia da vontade se vê, na afirmação de Roppo, relançada em novas bases e para desempenho de um novo papel". GODOY, Claudio Luiz Bueno de. Função social do contrato: os novos paradigmas contratuais. São Paulo: Saraiva. 2004. p. 7. Giselda Hironaka e Flávio Tartuce destacam que "[...] o princípio da autonomia privada pode ser conceituado como sendo um
} 
éticos, valorativos e humanísticos ${ }^{18}$.

Na esteira desse movimento, promulga-se no Brasil a Constituição Federal de 1988, qualificada como Constituição Cidadã, que consagra como valores e princípios fundamentais do "pacto de convivência coletiva" a cidadania (art. $1^{\circ}$, inciso II, da CF), a dignidade da pessoa humana (art. $1^{\circ}$, inciso III, da CF), a solidariedade social, a igualdade (art. $5^{\circ}$, caput, CF), a função social da propriedade (art. 5, inciso XXIII, e art. 170, inciso III, da CF), dentre outros, sobre os quais passa a se fundar e se interpretar todo o ordenamento jurídico brasileiro, inclusive o direito privado.

Ocorre uma "constitucionalização"19 do direito civil, na medida em que os direitos previstos na legislação infraconstitucional passam a sofrer a irradiação direta da Constituição, devendo a sua interpretação e aplicação atender aos valores fundamentais ${ }^{20}$.

regramento básico, de ordem particular - mas influenciado por normas de ordem pública -, pelo qual, na formação dos contratos, além da vontade das partes, entram em cena outros fatores: psicológicos, políticos, econômicos e sociais. Trata-se do direito indeclinável da parte de auto-regulamentar os seus interesses, decorrente da sua própria dignidade humana, mas que encontra limitações em normas de ordem pública, particularmente nos princípios sociais contratuais". HIRONAKA, Giselda Maria Fernandes Novaes; TARTUCE, Flávio. O princípio da autonomia privada e o direito contratual brasileiro. In: HIRONAKA, Giselda Maria Fernandes Novaes; TARTUCE, Flávio (Coord.). Direito contratual. Temas Atuais. São Paulo: Método, 2007. p. 49.

${ }^{18}$ Pietro Perlingieri observa que "o negócio jurídico, por exemplo, nasceu como poder da vontade do sujeito, como máxima expressão do individualismo. Nos mesmos termos exclusivamente individualistas e subjetivistas, a doutrina mais antiga concebia também o direito subjetivo. Com a passagem do individualismo à solidariedade constitucional, aquele particular negócio, que é o contrato, não diz respeito exclusivamente aos sujeitos estipuladores, mas, enquanto socialmente relevante, não se subtrai a um juízo de valor e, portanto, à positiva valoração do ordenamento" (PERLINGIERI, PIETRO. O direito civil na legalidade constitucional. Tradução de Maria Cristina De Cicco. Rio de Janeiro: Renovar. 2008. p. 142).

19 Sobre a constitucionalização do direito civil, confira-se: PERLINGIERI, PIETRO. O direito civil na legalidade constitucional. Tradução de Maria Cristina De Cicco. Rio de Janeiro: Renovar. 2008. Sobre o tema, Teresa Negreiros afirma que "a leitura do direito civil sob a ótica constitucional atribui novos fundamentos e, consequentemente, novos contornos à liberdade contratual. Em meio ao processo de despatrimonialização ou de funcionalização do direito civil, a noção de autonomia da vontade sofre profundas modificações no âmbito do contrato, sintetizadas na afirmação de que a autonomia negocial, diferentemente das liberdades essenciais, não constitui em si mesma um valor. Ao contrário, a livre determinação do conteúdo do regulamento contratual encontra-se condicionada à observância das regras e dos princípios constitucionais, o que significa, no quadro de valores apresentado pela Constituição brasileira, conceder o contrato como um instrumento a serviço da pessoa, sua dignidade e desenvolvimento. Assim, pela via da constitucionalização, passam a fazer parte do horizonte contratual noções e ideais como justiça social, solidariedade, erradicação da pobreza, proteção ao consumidor, a indicar, enfim, que o direito dos contratos não está à parte do projeto social articulado pela ordem jurídica em vigor no país" NEGREIROS, Teresa. Teoria do contrato: novos paradigmas. 2.ed. Rio de Janeiro: Renovar. 2006. p.106.

${ }^{20}$ LUNARDI, Fabrício Castagna. A teoria do abuso de direito e as novas formas de inadimplemento das obrigações: perspectivas atuais à luz da constitucionalização do direito civil. In: ANDRIGHI, Fátima Nancy (Coord.). Responsabilidade civil e inadimplemento no direito brasileiro. São Paulo: Atlas. 2014, p. 36. 
O Código Civil agora deve se adaptar e ser interpretado e aplicado à luz da Constituição. As relações privadas, que antes eram disciplinadas apenas pelo Código Civil, também passam a ser regidas diretamente pela Constituição e pelos seus princípios. Desta maneira, os conceitos e institutos tradicionais do direito civil passam a ser relidos e reinterpretados à luz dos princípios previstos na Constituição Federal de 1988, havendo uma "revisão axiológica" do direito privado ${ }^{21}$.

Nas precisas palavras de Eugênio Facchini Neto:

Realmente, constata-se que a migração de institutos e princípios do direito privado para o texto constitucional acarreta uma mudança de perspectiva, pois "de modo contrário ao Código Civil, que conserva os valores da sociedade liberal do Século XIX, a Constituição projeta e estimula a fundação de uma nova sociedade". Isso significa que o valor da segurança, ligada à estabilidade das relações jurídicas, que caracterizava as codificações liberais, deve saber transigir com o valor da esperança, ligada à transformação do existente, em prol de uma nação comprometida com o horizonte traçado na Carta Maior - a criação de uma sociedade, mais justa, livre e solidária, com vida digna para todos, em ambiente caracterizado por intenso pluralismo. ${ }^{22}$

Seguindo essas diretrizes constitucionais, o Código Civil de 2002 foi construído sob a égide de três bases principiológicas: a socialidade, a eticidade e a operabilidade. A socialidade consiste na exigência de que as relações privadas se desenvolvam de maneira alinhada com os objetivos da coletividade. A eticidade representa uma aposta do ordenamento jurídico na importância da postura ética do indivíduo no âmbito de suas relações jurídicas, obrigando-o a comportar-se conforme a boa-fé e os bons costumes. Por fim, a operabilidade refere-se à busca por um ordenamento jurídico voltado à efetivação, e não apenas ao reconhecimento e proclamação de direitos e regras em abstrato ${ }^{23}$.

\footnotetext{
${ }^{21}$ No mesmo sentido: “[...] conforme a constitucionalização do direito privado firmou-se como orientação indispensável à interpretação e aplicação do direito brasileiro - exigindo a releitura, em chave funcional, de todos os institutos e sua consequente funcionalização aos valores do ordenamento -, nenhuma figura civilística pôde manter-se alheia à incidência da axiologia constitucional - nem mesmo os milenares conceitos do direito obrigacional" (FURTADO, Gabriel Rocha. Mora e inadimplemento substancial. São Paulo: Atlas. 2014. p. 1-2).

${ }^{22}$ NETO, Eugênio Facchini. A revitalização do direito privado brasileiro a partir do Código de Defesa do Consumidor. In: 20 anos do Código de Defesa do Consumidor: conquistas, desafios e perspectivas. LOTUFO, Renan; MARTINS, Fernando Rodrigues (Coord.). São Paulo: Saraiva. 2011. p. 37.

${ }^{23}$ LEAL, Adisson. Violação Positiva dos Contratos. In: Responsabilidade civil e inadimplemento no direito brasileiro. Fátima Nancy Andrighi (coord,). São Paulo: Atlas. 2014, p. 2.
} 
Os mencionados princípios ganham contornos vívidos principalmente por intermédio das cláusulas gerais ${ }^{24}$ e dos conceitos jurídicos indeterminados utilizados pelo legislador ao longo de todo o Código Civil de 2002, que garantem um "sistema aberto" que permite que o intérprete tenha um papel ativo na determinação do sentido das normas jurídicas, de acordo com os padrões culturais e éticos da sociedade e com o momento histórico e com a comunidade em que é aplicado ${ }^{25}$.

A "revisão axiológica" do direito obrigacional também foi impulsionada pela recepção de novos princípios contratuais ${ }^{26}$ - boa-fé objetiva, equilíbrio econômico do contrato (ou equivalência material) e função social do contrato -, que passam a coexistir e ser aplicados conjuntamente com os princípios tradicionais ou liberais, realçando a exigência moderna de que as relações privadas também devem se preocupar com as noções de eticidade e solidariedade, conforme o perfil traçado pela Constituição Federal de $1988^{27}$.

\footnotetext{
${ }^{24}$ Utiliza-se o conceito de "cláusula geral” de Judith Martins-Costa: “norma jurídica cujo enunciado, ao invés de traçar punctualmente a hipótese e as suas consequências, é intencionalmente desenhado como uma vaga moldura, permitindo, pela abrangência de sua formulação, a incorporação de princípios, diretrizes, máximas de conduta originalmente estrangeiros ao corpus codificado, bem como a constante formulação de novas normas". (COSTA, Judith Martins. Sistema e cláusula Geral: a boa-fé objetiva no processo obrigacional. Tese (doutorado). Faculdade de Direito. São Paulo: USP, 1996).

${ }^{25}$ LUNARDI, Fabrício Castagna. A teoria do abuso de direito e as novas formas de inadimplemento das obrigações: perspectivas atuais à luz da constitucionalização do direito civil. In: Responsabilidade civil $e$ inadimplemento no direito brasileiro. ANDRIGHI, Fátima Nancy (Coord.). São Paulo: Atlas, 2014, p. 38. Vale conferir as lições de José Fernando Simão a respeito da questão: "como o legislador tem consciência de que não pode prever todos os acontecimentos, ele acaba se valendo do recurso aos conceitos de conteúdo variável ou de cláusulas gerais, como a boa-fé, equidade, ordem pública etc. Neste sentido, o objetivo é deixar o juiz avaliar cada caso segundo as circunstâncias correspondentes e adaptar as consequências legais às características do caso concreto. [...] O Código Civil de 2002 adotou em vários dispositivos esse modelo aberto para que, mesmo com o passar do tempo, não seja necessária a mudança da lei. Basta o juiz, quando da análise do caso concreto, aplicar os valores daquele momento, e não do momento em que a regra foi concebida" (SIMÃO, José Fernando. Prescrição e decadência: início dos prazos. São Paulo: Atlas, 2013. p. 71).

${ }^{26}$ HIRONAKA, Giselda Maria Fernandes Novaes. Direito das Obrigações no novo Código Civil brasileiro e regime jurídico da inadimplência contratual. 2008. p. 2. Disponível em: http://www.migalhas.com.br/arquivo_artigo/art20101116-01.pdf. Acesso em: 15 fev. 2013.

27 A esse respeito, Cláudia Lima Marques comenta que: "Essa renovação teórica do contrato à procura de equiidade, da boa-fé e da segurança nas relações contratuais vai aqui ser chamada de sociabilização da teoria contratual. É importante notar que esta sociabilização, na pratica, se fará sentirem poderoso intervencionismo do Estado na vida dos contratos e na mudança de paradigmas, impondo-se o princípio da boa-fé objetiva na formação e da execução das obrigações. A reação do direito virá através de ingerências legislativas cada vez maiores nos campos antes reservados para a autonomia da vontade, tudo de modo a assegurar a justiça e o equilíbrio contratual na nova sociedade de consumo". MARQUES, Cláudia Lima. Contratos no Código de Defesa do Consumidor: o novo regime das relações contratuais. p. 154-155.. Para uma análise destes novos princípios contratuais, ver TEPEDINO, Gustavo. Novos Princípios contratuais e teoria da confiança: a exegese da cláusula to the best knowledge of the sellers. Temas de direito civil. Rio de Janeiro: Renovar. 2006 , t. II.
} 
Assim, embora o "tecido normativo das obrigações [se tenha] mantido imune a qualquer projeto de reforma, não merecendo mais que alterações tímidas da parte do legislador" 28 , inclusive no Código Civil brasileiro de $2002^{29}$, o seu intérprete poderá e deverá realizar uma releitura do regramento, dos conceitos e institutos do direito das obrigações, valendo-se das normas constitucionais e das cláusulas gerais previstas no Código Civil de 2002, especialmente a boa-fé objetiva, para permitir que esse campo do direito civil esteja apto a solucionar os conflitos atualmente existentes na sociedade ${ }^{30}$.

É por essa razão que no tópico a seguir será feita uma breve análise do princípio da boa-fé objetiva, que provocou profundas alterações no ramo do direito das obrigações e servirá de base para o estudo do tema do inadimplemento antecipado dos contratos. Destaque-se que, como não poderia deixar de ser, o objetivo do presente trabalho não é esgotar a análise de tal princípio, já que isso fugiria do objeto desse estudo, mas apenas conceituá-lo e ilustrar algumas das suas peculiaridades e formas de aplicação, para lançar as bases teóricas para o exame do inadimplemento antecipado dos contratos.

\subsection{A repercussão do princípio da boa-fé objetiva no âmbito do direito das obrigações}

\footnotetext{
${ }^{28}$ SCHREIBER, Anderson. A boa-fé objetiva e o adimplemento substancial. In: HIRONAKA, Giselda Maria Fernandes Novaes; TARTUCE, Flávio (Coord.). Direito contratual. Temas Atuais. São Paulo: Método. 2007. p. 128.

${ }^{29}$ Neste sentido: "Chegando ao fim deste percurso de anotações gerais sobre o direito obrigacional no novo Código Civil, cabe-me verificar se cumpri aquilo a que me dispus a fazer: procurar demonstrar que a maioria das parcas alterações sofridas pelo Código Civil no que concerne à Parte Geral do Direito das Obrigações são, na verdade, simples alterações lógicas a que se chegava pela aplicação dos princípios gerais do direito relativos à matéria em apreço; outras são transcrições do gênio dos autores que escreveram sobre a matéria, idéias agora positivadas. E se atentarmos melhor, poderemos verificar que as principais alterações, aquelas mais interessantes e revolucionárias que se encontram neste último Título relativo ao inadimplemento das obrigações, são regras de responsabilidade civil e não de teoria geral das obrigações”. HIRONAKA, Giselda Maria Fernandes Novaes. Direito das obrigações: o caráter de permanência dos seus institutos, as alterações produzidas pela lei civil brasileira de 2002 e a tutela das futuras gerações. In: DELGADO, Mário Luiz; ALVES, Jones Figueirêdo (Coord.). Questões controvertidas no direito das obrigações e dos contratos. Série Grandes Temas de Direito Privado. v. 4. Editora Método: São Paulo. 2005. p. 29.

${ }^{30}$ SCHREIBER, Anderson. A boa-fé objetiva e o adimplemento substancial. In: HIRONAKA, Giselda Maria Fernandes Novaes; TARTUCE, Flávio (Coord.). Direito contratual. Temas Atuais, São Paulo: Método. 2007. p. 128.
} 
O Código Civil de 2002 adotou expressamente o princípio da boa-fé (em sua acepção objetiva) no campo das relações civis paritárias, o que acarretou profunda alteração no direito obrigacional clássico, notadamente nos deveres impostos para as partes durante a relação obrigacional e nos conceitos de adimplemento e de inadimplemento.

A boa-fé objetiva consiste, em linhas gerais, em um padrão de comportamento exigido das partes contratantes, uma conduta leal, escorreita, caracterizando um standard jurídico em que as atitudes das pessoas são valoradas de acordo com os padrões de lealdade, probidade e honestidade, como se vê na obra de Cláudia Lima Marques:

\begin{abstract}
A boa-fé objetiva significa uma atuação refletida, uma atuação refletindo, pensando no outro, no parceiro contratual, respeitando-o, respeitando seus interesses legítimos, suas expectativas razoáveis, seus direitos, agindo com lealdade, sem abuso, sem causar lesão ou vantagens excessivas, cooperando para atingir o bom fim das obrigações: o cumprimento do objetivo contratual e a realização dos interesses das partes. ${ }^{31}$
\end{abstract}

Diferentemente da boa-fé subjetiva, que se refere a um estado anímico ou psicológico do indivíduo, a boa-fé objetiva corresponde a uma regra de conduta, um modelo de comportamento social que se espera dos indivíduos. Na doutrina brasileira, exemplificativamente, vale conferir as observações de Fernando Noronha:

\begin{abstract}
Mais do que duas concepções de boa-fé, existem duas boas-fés, ambas jurídicas, uma subjetiva, a outra objetiva. A primeira diz respeito a dados internos, fundamentalmente psicológicos, atinentes diretamente ao sujeito, a segunda a elementos externos, a normas de conduta, que determinam como ele deve agir. Num caso, está de boa-fé quem ignora a real situação jurídica; no outro, está de boa-fé quem tem motivos para confiar na contraparte. Uma é boa-fé é estado, a outra, boa-fé princípio. ${ }^{32}$
\end{abstract}

A boa-fé que constitui inovação no Código Civil de 2002 e que acarretou profunda alteração no direito obrigacional é a objetiva, que consiste em uma regra de conduta segundo a qual todos devem comportar-se de maneira correta, leal e proba durante

\footnotetext{
${ }^{31}$ MARQUES, Cláudia Lima. Contratos no Código de Defesa do Consumidor. São Paulo: Ed. Revista dos Tribunais. 3. ed., $2^{\mathrm{a}}$ tiragem. p. 106.

${ }^{32}$ NORONHA, Fernando. O direito dos contratos e os princípios fundamentais: autonomia privada, boa-fé, justiça contratual. São Paulo: Saraiva. 1994. p. 132.
} 
as tratativas, a formação, o cumprimento e a extinção do contrato ${ }^{33}$. É, portanto, a boa-fé como fonte de direitos e obrigações ${ }^{34}$.

A boa-fé objetiva mereceu três importantes referências no Código Civil de 2002, quais sejam: (a) "Os negócios jurídicos devem ser interpretados conforme a boa-fé e os usos do lugar de sua celebração" (artigo 113); (b) "Comete ato ilícito o titular de um direito que, ao exercê-lo, excede manifestamente os limites impostos pelo seu fim econômico ou social, pela boa-fé ou pelos bons costumes" (artigo 187); e (c) "Os contratantes são obrigados a guardar, assim na conclusão do contrato, como em sua execução, os princípios de probidade e boa-fê" (artigo 422).

Apesar de o Código Civil de 2002 ter feito referência à boa-fé objetiva em três diferentes artigos, o diploma legal não estabeleceu parâmetros ou standards de conduta que determinassem o seu conteúdo. Nas palavras de Judith Martins-Costa, "não é possível, efetivamente, tabular ou arrolar, a priori, o significado da valoração a ser procedida mediante a boa-fé objetiva, porque se trata de uma norma cujo conteúdo não pode ser rigidamente fixado, dependendo das concretas circunstâncias do caso"35.

Trata-se de uma nova técnica adotada pelo legislador, da qual o novo Código Civil é repleto (cláusulas gerais), em oposição à técnica tradicional da casuística, cujo propósito é permitir o preenchimento do conteúdo da norma e a sua concretização pelo intérprete $^{36}$. Assim, caberá ao julgador, à luz dos valores estabelecidos pela Constituição

\footnotetext{
${ }^{33}$ Ruy Rosado Aguiar Júnior assevera que "não é essa [subjetiva] a boa-fé que aqui mais nos interessa, e sim a boa-fé objetiva, que se constitui em uma norma jurídica, ou melhor, em um princípio geral do direito, segundo o qual todos devem comportar-se de boa-fé nas suas relações recíprocas. A inter-relação humana deve pautar-se por um padrão ético de confiança e lealdade, indispensável para o próprio desenvolvimento normal da convivência social. A expectativa de um comportamento adequado por parte do outro é um componente indissociável da vida de relação, sem o qual ela mesma seria inviável" (AGUIAR JR., Ruy Rosado. Extinção dos contratos por incumprimento do devedor (resolução). Rio de Janeiro: Aide, 1991. p. 239).

${ }^{34}$ GONÇALVES, Carlos Roberto. Direito civil brasileiro. v. 3: contratos e atos unilaterais. São Paulo: Saraiva. 2012, 9. ed. p. 56.

${ }^{35}$ COSTA, Judith Martins. A boa-fé no direito privado. São Paulo: Ed. Revista dos Tribunais, p. 412.

${ }^{36}$ A esse respeito, Ruy Rosado afirma que "a regra da boa-fé é uma cláusula geral, como tantas outras do nosso ordenamento (art. $5^{\circ}$ da Lei de Introdução ao Código Civil, art. 159 do Código Civil), que serve ao aperfeiçoamento e à integração do sistema e à garantia de vigência e eficácia do princípio de justiça. É um fato operacional de importância considerável para a flexibilização do direito normado. O conteúdo da norma de dever, derivada do princípio da boa-fé, não está na lei, devendo ser composto caso a caso pelo juiz; exige
} 
Federal, dos princípios norteadores do Código Civil de 2002 e dos padrões éticos vigentes, analisar se em um dado caso concreto o comportamento das partes foi pautado pela honestidade, lealdade e probidade.

A despeito da indeterminação do conceito de boa-fé objetiva no Código Civil, a doutrina assevera que esta não pode servir a qualquer fim. ${ }^{37}$ Neste sentido, sustenta-se que a boa-fé objetiva possui tríplice função ${ }^{38}$, assim composta: (i) função interpretativa dos contratos (artigo 113); (ii) função restritiva do exercício abusivo de direitos contratuais (artigo 187); e (iii) função criadora de deveres anexos ou acessórios à prestação principal $^{39}$ (artigo 422).

Confiram-se os ensinamentos de Karl Larenz acerca da tríplice função desempenhada pela boa-fé objetiva:

\begin{abstract}
El principio de la buena fe desarrolla su fuerza en una triple dirección.
En primer lugar, se dirige al deudor, con el mandato de cumplir su obligación, ateniéndose no solo a la letra, sino también al espíritu de la relación obligatoria correspondiente - en especial conforme al sentido y la idea fundamental del contrato $(\S 157)$ - y en la forma que el acreedor puede razonablemente esperar de él.

En segundo lugar, se dirige al acreedor, con el mandato de ejercitar el derecho que le corresponde, actuando según la confianza depositada por la otra parte y la consideración altruista que esta parte pueda pretender según la clase de vinculación especial existente.
\end{abstract}

atividade judicante que, sem mediações normativas, deixa face a face o sistema global e o caso a se resolver. [...] A norma principal da boa-fé, expressa ou implícita na lei, é uma norma em branco, cujo preceito ordenador da conduta deve ser fixado na espécie. Somente depois dessa determinação, com o preenchimento do vazio normativo, será possível precisar o conteúdo e o limite dos direitos e deveres das partes". AGUIAR JR., Ruy Rosado. Extinção dos contratos por incumprimento do devedor (resolução). Rio de Janeiro: Aide, 1991. p. 242.

${ }^{37}$ TEPEDINO, Gustavo; SCHREIBER, Anderson. A Boa-fé Objetiva no Código de Defesa do Consumidor e no Novo Código Civil. In: TEPEDINO, Gustavo. Obrigações: estudos na perspectiva civil-constitucional. Rio de Janeiro: Renovar. 2005. p. 35.

${ }^{38}$ GOMES, Orlando. Contratos. Rio de Janeiro: Forense. 2008. p.44.

39 Podemos, então, definir boa-fé como um "princípio geral de Direito, segundo o qual todos devem comportar-se de acordo com um padrão ético de confiança e lealdade. Gera deveres secundários de conduta, que impõem às partes comportamentos necessários, ainda que não previstos expressamente nos contratos, que devem ser obedecidos a fim de permitir a realização das justas expectativas surgidas em razão da celebração e da execução da avença." AGUIAR JÚNIOR, Ruy Rosado de. Cláusulas abusivas no Código do Consumidor. In: MARQUES, Cláudia Lima (Coord.). Estudos sobre a proteção do consumidor no Brasil e no Mercosul. Livraria Editora do Advogado. 1994. 
En tercer lugar, se dirige a todos los participantes en la relación jurídica en cuestión, con el mandato de conducirse como corresponda en general al sentido y finalidad de esta especial vinculación y a una conciencia honrada. ${ }^{40}$

No tocante à função interpretativa, considera-se a boa-fé como um critério hermenêutico que exige que a interpretação das cláusulas contratuais privilegie o sentido mais conforme à lealdade e honestidade das partes. Dessa forma, com base na boa-fé objetiva, se proíbe que a interpretação confira a uma cláusula contratual um sentido que possa prejudicar ou iludir uma parte em benefício de outra. Entende-se, assim, que as manifestações de vontade devem ser interpretadas em consonância com a legítima expetativa criada no contratante ${ }^{41}$.

A função restritiva da boa-fé objetiva vem servir de limite para o exercício de direitos no âmbito de uma relação contratual, evitando-se o abuso no exercício de um direito. Nesse caso, a boa-fé objetiva é utilizada como um critério para a diferenciação entre o exercício regular e o exercício irregular ou abusivo - e, portanto, vedado - de direitos frente à outra parte na relação contratual $^{42}$. Nessa função, a boa-fé atua como "parâmetro de valoração do comportamento dos contratantes: o exercício de um direito será irregular, abusivo, se consubstanciar quebra de confiança"43 e, portanto, contrário à boa-fé.

\footnotetext{
${ }^{40}$ LARENZ, Karl. Derecho de obligaciones. tomo I. Trad. de Jaime Santos Briz, Madrid: Editora Revista de Derecho Privado. 1958. p. 148. Em tradução livre: “o princípio da boa-fé desenvolve a sua força em três direções. Em primeiro lugar, se dirige ao devedor, com a missão de cumprir a sua obrigação, de acordo não só com a letra, mas também com o espírito da relação obrigacional - especialmente dentro do sentido e da ideia fundamental do contrato $(\$ 157)$ - e do que o credor pode razoavelmente esperar dele. Em segundo lugar, ele se dirige ao credor, com uma determinação para exercer o direito que lhe corresponde agindo de acordo com a confiança que lhe depositou a outra parte e a mente altruísta de que esta parte pode reclamar de acordo com o tipo relação existente. Em terceiro lugar, se dirige a todos os participantes da relação jurídica em questão, com a determinação de se conduzirem de acordo com o sentido e a finalidade da relação especial e uma consciência honesta."

${ }^{41}$ TEPEDINO, Gustavo; SCHREIBER, Anderson. A Boa-fé Objetiva no Código de Defesa do Consumidor e no Novo Código Civil. In: TEPEDINO, Gustavo. Obrigações: estudos na perspectiva civil-constitucional. Rio de Janeiro: Renovar. 2005, p. 36. No mesmo sentido: GODOY, Claudio Luiz Bueno de. Função social do contrato: os novos paradigmas contratuais. São Paulo: Saraiva, 2004. p. 77.

42 TEPEDINO, Gustavo e SCHREIBER, Anderson. A Boa-fé Objetiva no Código de Defesa do Consumidor e no Novo Código Civil. In: TEPEDINO, Gustavo. Obrigações: estudos na perspectiva civil-constitucional. Rio de Janeiro: Renovar. 2005. p. 36.

${ }^{43}$ NEGREIROS, Teresa. Teoria do contrato: novos paradigmas. Rio de Janeiro: Renovar, 2, ed., 2006. p.141.
} 
A função restritiva da boa-fé objetiva é vista por parcela da doutrina brasileira como um dos fundamentos da proibição de venire contra factum proprium, que veda que as partes adotem comportamentos contraditórios ao longo de uma relação contratual ${ }^{44}$. A boa-fé protege uma parte contra aquela que pretende exercer uma posição jurídica em contradição com o comportamento assumido anteriormente. Depois de criar certa expectativa, a parte viola o princípio da boa-fé se praticar ato contrário ao comportamento que seria previsível, com surpresa e prejuízo à contraparte ${ }^{45}$. Nesse sentido se posiciona Judith Martins-Costa:

\begin{abstract}
A proibição de toda e qualquer conduta contraditória seria, mais do que uma abstração, um castigo. Estar-se-ia a enrijecer todas as potencialidades da surpresa, do inesperado e do imprevisto na vida humana. Portanto, o princípio que o proíbe como contrário ao interesse digno da tutela jurídica é o comportamento contraditório que mine a relação de confiança recíproca minimamente necessária para o bom desenvolvimento do tráfego negocial. ${ }^{46}$
\end{abstract}

Ainda decorrente dessa limitação aos direitos subjetivos aparecem duas figuras que são verso e reverso uma da outra. Trata-se da suppressio e da surrectio. Em linhas gerais, a supressio consiste na ineficácia de um direito subjetivo em virtude da prolongada inércia do seu titular, enquanto a surrectio é justamente o oposto, a aquisição da eficácia de um direito decorrente da inércia alheia ${ }^{47}$. Exemplo da suppressio e da surrectio é a duradoura distribuição de lucros de sociedade comercial em desacordo com os estatutos sociais, que pode gerar o direito de recebê-los do mesmo modo para o futuro. ${ }^{48}$

\footnotetext{
${ }^{44}$ Na IV Jornada de Direito Civil promovida pelo Conselho da Justiça Federal foi aprovado o Enunciado 362, que dispõe que: "A vedação do comportamento contraditório (venire contra factum proprium) funda-se na proteção da confiança, tal como se extrai dos artigos 187 e 422 do Código Civil."

${ }^{45}$ AGUIAR JÚNIOR, Ruy Rosado de. Extinção dos contratos por incumprimento do devedor. Rio de Janeiro: AIDE, 2. ed. 1991. p. 248.

${ }^{46}$ COSTA, Judith Martins. A boa-fé no direito privado. Ed. Revista dos Tribunais. p. 470.

${ }^{47}$ NICOLAU, Gustavo Rene. Implicações Práticas da boa-fé objetiva. In: HIRONAKA, Giselda Maria Fernandes Novaes; TARTUCE, Flávio (Coord.). Direito contratual. Temas Atuais. São Paulo: Método. 2007. p. 120. José Fernando Simão afirma que "a supressio pode ser definida como a impossibilidade de exercício de uma posição jurídica em razão da sua não utilização por um período de tempo. Se pudesse ser exercida esta posição, a boa-fé seria contrariada. Já a surrectio é a oura face da moeda, ou seja, a posição jurídica que passa a ser exercida em decorrência da supressio. O art. 330 do Código Civil traz um ótimo exemplo dos institutos: 'O pagamento reiteradamente feito em outro local faz presumir renúncia do credor relativamente ao previsto no contrato'”. SIMÃO, José Fernando. Prescrição e decadência: início dos prazos. São Paulo: Atlas. 2013. p. 194.

${ }^{48}$ AGUIAR JÚNIOR, Ruy Rosado de. Extinção dos contratos por incumprimento do devedor. 2. ed. Rio de Janeiro: AIDE. 1991. p.249.
} 
A função restritiva da boa-fé objetiva também atua no sistema de direito privado brasileiro (tanto no âmbito do Código Civil como no do Código de Defesa do Consumidor) como cláusula geral para controle das cláusulas abusivas ou leoninas -, que acarretam desequilíbrio contratual e desproporção entre os direitos e deveres (principais, secundários e acessórios) das partes, com efeitos que beneficiam uma parte e oneram excessivamente a outra. Conforme leciona Cláudia Lima Marques,

\begin{abstract}
A própria idéia de abuso do direito, agora positivada no novo Código Civil de 2002, está relacionada com a boa-fé (Art. 187 do CC/2002). Seguindo-se esta idéia (e retirando-a do campo extracontratual para utilizá-la analogicamente no campo contratual),e unindo-a a do art. 4,III e art. 51, IV e § do CDC, poderíamos afirmar, sucintamente, que cláusula abusiva é aquela que viola a boa-fé obrigatória das relações entre iguais (ex vi novo Código Civil) e entre desiguais (ex vi Código de Defesa do Consumidor, que possui este mesmo princípio da boa-fé e quando a relação civil ou empresarial é desequilibrada pelo contrato de adesão, ex vi art. 424 do CC/2002).

Portanto, podemos dizer que uma cláusula desequilibra um contrato porque ela viola um dever principal, inerente àquele sistema, àquele tipo de contrato (essa idéia está no artigo 51 do Código de Defesa do Consumidor), mas podemos também dizer que determinada cláusula é abusiva, porque viola os deveres que a própria boa-fé introduziu naquela relação. ${ }^{49}$
\end{abstract}

Por fim, a boa-fé também tem a função integrativa ${ }^{50}$, exercendo o papel de fonte criadora de deveres anexos à prestação principal (também chamados laterais, secundários ou instrumentais), que são deveres não estipulados expressamente pelas partes ou previstos em lei que tem por fim assegurar o cumprimento perfeito da prestação e a satisfação integral dos interesses envolvidos no contrato ${ }^{51}$.

${ }^{49}$ MARQUES, Cláudia Lima. Das Cláusulas Abusivas e o Código Civil. Anais do "EMERJ Debate o Novo Código Civil". p. 257. Disponível em:

<http://www.emerj.tjrj.jus.br/revistaemerj_online/edicoes/anais_onovocodigocivil/anais_especial_1/Anais_P arte_I_revistaemerj_249.pdf>. Acesso em: 11 jul. 2013.

${ }^{50}$ Destaque-se que a boa-fé enquanto fonte geradora de deveres anexos encontra-se presente no artigo 422 do Código Civil ("Os contratantes são obrigados a guardar, assim na conclusão do contrato, como em sua execução, os princípios de probidade e boa-fé"). A redação do artigo 422 do Código Civil, todavia, tem sido bastante criticada pela doutrina. Antônio Junqueira de Azevedo, por exemplo, a considera insuficiente, "pois só dispõe sobre dois momentos: conclusão do contrato - isto é, o momento em que o contrato se faz - e execução. Nada preceitua sobre o que está depois, nem sobre o que está antes" (AZEVEDO, Antonio Junqueira de. Insuficiências, deficiências e desatualização do projeto de Código Civil na questão da boa-fé objetiva nos contratos, $R T, 775 / 11)$. A doutrina brasileira majoritária entende que a cláusula geral de boa-fé atua nos contratos em três fases: na fase pré-contratual, na fase de execução do contrato e na fase póscontratual. Nesse sentido, o Enunciado $\mathrm{n}^{\circ}$ 170, da III Jornada de Direito Civil do Centro de Estudos Judiciários do Conselho da Justiça Federal, que estabelece que: "Art. 422: A boa-fé objetiva deve ser observada pelas partes na fase de negociações preliminares e após a execução do contrato, quando tal exigência decorrer da exigência do contrato."

${ }^{51}$ Ruy Rosado assevera que "na formação e na execução do contrato, o real conteúdo das obrigações e o modo pelo qual devem as partes se comportar são determinações a serem feitas com o auxílio do princípio da 
Judith Martins-Costa conceitua os deveres laterais como

[...] deveres de adoção de determinados comportamentos, impostos pela boa-fé em vista do fim do contrato [...] dada a relação de confiança em que o contrato fundamenta, comportamentos variáveis com as circunstâncias concretas da situação. Ao ensejar a criação desses deveres, a boa-fé atua como fonte de integração de conteúdo contratual, determinando a sua otimização, independentemente da regulação voluntaristicamente estabelecida. ${ }^{52}$

Com efeito, em todo contrato existem as chamadas cláusulas centrais ou nucleares, que são as principais obrigações das partes dentro do contrato e geralmente definem o tipo contratual. Acontece que a boa-fé objetiva impõe às partes deveres que não são os centrais ou nucleares, mas que estão anexos, marginais, laterais ao contrato e que, muitas vezes, nem sequer foram previstos pelas partes ou em lei. São deveres decorrentes da justa expectativa que existe nas relações sociais de sempre lidar com pessoas íntegras e probas, que visam garantir a segurança da contraparte e do seu patrimônio, o fim do contrato, a plena informação das partes, etc. ${ }^{53}$.

Segundo as lições de Motta Pinto, em toda relação contratual existem deveres principais, secundários e laterais. Os deveres principais seriam os que definem o tipo do contrato (obrigações de pagar o preço e entregar a coisa no contrato de compra e venda). Os deveres secundários, por sua vez, se dividem em deveres secundários com prestação autônoma, que substituem o dever principal na falta ou impossibilidade de cumprimento deste (por exemplo, a indenização por perdas e danos no caso de inadimplemento), e deveres secundários acessórios da prestação principal, que são voltados para a efetiva realização da prestação principal (por exemplo, o dever do vendedor de transportar ou embalar a coisa vendida). Há, ainda, os deveres laterais, instrumentais ou anexos, que têm

boa-fé, que servirá não apenas para a interpretação integradora das cláusulas do contrato, mas ainda para o reconhecimento de deveres secundários, derivados diretamente do princípio, independentemente da vontade manifestada pelas partes, a serem observados durante a fase de formação e cumprimento da obrigação. São deveres que excedem o dever de prestação". AGUIAR JR., Ruy Rosado. Extinção dos contratos por incumprimento do devedor (resolução). Rio de Janeiro: Aide, 1991. p. 246.

${ }_{52}$ COSTA, Judith Martins. A boa-fé no direito privado. Ed. Revista dos Tribunais. p. 440.

53 NICOLAU, Gustavo Rene. Implicações Práticas da boa-fé objetiva. In: HIRONAKA, Giselda Maria Fernandes Novaes; TARTUCE, Flávio (Coord.). Direito contratual. Temas Atuais. São Paulo: Método. 2007. p. 117. 
por fim assegurar o cumprimento perfeito da prestação e a satisfação integral dos interesses envolvidos no contrato ${ }^{54}$.

Entre os deveres laterais, instrumentais ou anexos a doutrina costuma apontar: (i) os deveres de cuidado, previdência e segurança; (ii) os deveres de aviso e de esclarecimento; (iii) os deveres de informação; (iv) os deveres de colaboração e cooperação; (iv) os deveres de proteção e cuidado com a pessoa e o patrimônio da contraparte; e (v) os deveres de omissão e de segredo ${ }^{55}$.

Apesar da multiplicidade de deveres laterais, António Menezes Cordeiro entende que é possível reconduzir esses deveres anexos a três categorias gerais: dever de proteção, de esclarecimento e de lealdade ${ }^{56}$. O dever de proteção impõe que os contratantes não gerem danos ao patrimônio ou à pessoa um do outro. Os deveres de esclarecimento impõem que haja entre as partes informações contínuas e suficientes sobre qualquer situação que possa influir na sorte do contrato. O dever de lealdade ${ }^{57}$ impõe que o resultado obtido pelas partes com o contrato não tenha sua utilidade frustrada (por exemplo, não concorrência, vigência de outro contrato; de não celebração de contratos incompatíveis com o primeiro, etc $)^{58}$.

\footnotetext{
${ }^{54}$ MOTTA PINTO, Carlos Alberto da. Cessão de contrato. São Paulo: Saraiva. 1985. p. 278-279.

${ }^{55}$ COSTA, Judith Martins, A boa-fé no direito privado; Ed. Revista dos Tribunais. p. 439.

${ }^{56}$ MENEZES CORDEIRO, António. Da boa fé no direito civil. Coimbra: Almedina. 2011. p. 605.

${ }^{57}$ Menezes Cordeiro afirma que "os deveres acessórios de lealdade obrigam as partes a, na pendência contratual, absterem-se de comportamentos que possam falsear o objectivo do negócio ou desequilibrar o jogo das prestações por elas consignado. Com esse mesmo sentido, podem ainda surgir deveres de actuação positiva. A casuística permite apontar, como concretização desta regra, a existência, enquanto um contrato se encontre em vigor, de deveres de não concorrência, e não celebração de contratos incompatíveis com o primeiro, de sigílio, face a elementos obtidos por via da pendência contratual e cuja divulgação possa prejudicar a outra parte e de actuação com vista a preservar o objectivo da mera interpretação contratual, mas antes das exigências do sistema, face ao contrato considerado”. MENEZES Cordeiro, António Manuel da Rocha. Da boa-fé no direito civil. Coimbra: Almedina, 2011, p. 607.

${ }^{58}$ Clóvis do Couto e Silva classifica os deveres anexos em deveres dependentes e independentes, de acordo com a possibilidade de ultrapassarem o término da obrigação principal e, por consequência, terem vida própria. Os deveres anexos independentes assumem uma certa autonomia em relação à prestação principal embora dependam da obrigação principal para o seu nascimento -, o que faz com que possam ser acionados autonomamente, "sem acarretar o desfazimento da relação principal". Segundo o referido autor, isso acontece porque os deveres anexos independentes têm "fím próprio, diverso da obrigação principal". Dentre tais deveres, o autor menciona o dever do empregado que, nessa qualidade, tomou conhecimento de alguma circunstância relevante (segredo industrial, estratégia de mercado, etc.), de não levá-lo a conhecimento de empresa concorrente, mesmo após o término do seu contrato de trabalho. Os deveres anexos dependentes, por sua vez, são considerados "pertenças das obrigações principais", estão tão ligados à prestação principal que o seu descumprimento acarretará necessariamente o da prestação principal, razão plena qual não tem
} 
Vale destacar que os deveres anexos impostos pela boa-fé objetiva ora se impõem às partes de maneira positiva, exigindo dos contratantes determinado comportamento para permitir o adimplemento do contrato (deveres de lealdade, proteção, esclarecimento de informação, sigilo, colaboração), ora de maneira negativa, restringindo ou condicionando o exercício de um direito previsto em lei ou no contrato, atuando como um limite para o exercício abusivo de direitos (adimplemento substancial das obrigações $)^{59}$.

De uma certa maneira, os deveres laterais contêm uma notável proximidade com a confiança despertada em outrem ${ }^{60}$, isto é, com a legítima expectativa criada de que determinado comportamento será praticado para que seja atingido todo o programa obrigacional e os interesses das partes restem satisfeitos. Fernando Noronha acentua o papel preponderante dos deveres laterais quanto à legítima expectativa despertada nas partes contratantes, in verbis:

\begin{abstract}
Os deveres fiduciários, anexos, laterais, ou simplesmente meros deveres de conduta (às vezes chamados também de deveres correlatos, ou colaterais) são aqueles que somente apontam procedimentos que é legítimo esperar por parte de quem, no âmbito de um específico relacionamento obrigacional (em especial quando seja contratual ou ainda pré-contratual ou pós-contratual, e até supracontratual, isto é, neste caso, sendo concomitante a um contrato, mas indo além dele), age de acordo com os padrões socialmente recomendados de correção, lisura e lealdade, que caracterizam o chamado princípio da boa-fé contratual. ${ }^{61}$
\end{abstract}

A boa-fé objetiva constitui, assim, uma cláusula geral de limite da autonomia privada e de valoração da conduta das partes que resguarda a legítima expectativa das

acionabilidade própria. SILVA, Clóvis do Couto e. A obrigação como processo. Rio de Janeiro: Editora FGV, 2006. p. 96-97. Entendemos, todavia, que o critério mais adequado para diferenciar os diversos deveres anexos está na identificação dos efeitos que cada um deles produz na concreta relação obrigacional. Em outras palavras, mais importante do que apurar se certo dever de conduta se mantém depois da extinção da obrigação principal, é verificar sua relevância para a realização do resultado útil que o adimplemento da prestação objetiva alcançar.

${ }^{59}$ TEPEDINO, Gustavo; SCHREIBER, Anderson. A Boa-fé Objetiva no Código de Defesa do Consumidor e no Novo Código Civil. In: TEPEDINO, Gustavo. Obrigações: estudos na perspectiva civil-constitucional. Rio de Janeiro: Renovar. 2005. p. 37.

${ }^{60}$ LARENZ, Karl. Derecho de obligaciones. tomo I. Trad. de Jaime Santos Briz. Madrid: Editora Revista de Derecho Privado. 1958. p. 21.

${ }^{61}$ NORONHA, Fernando. Direito das obrigações. v. I. São Paulo: Saraiva. 2013. p. 100-101. 
partes, impregna a relação obrigacional de um caráter ético, leal e cooperativo e, principalmente, visa assegurar o adimplemento contratual e a plena satisfação dos interesses dos contratantes. Nas palavras de Cláudio Luiz Bueno de Godoy, “deixa de ser a vontade das partes, como dito, a fonte única da relação contratual, a fim de que a seu lado concorram valores e princípios que, mesmo não dispostos pelos contratantes, são impostos pelo ordenamento, antes de tudo pela própria Constituição do país" ${ }^{\prime 62}$.

Por se tratar de um princípio geral das relações contratuais, tem-se que a boa-fé objetiva é irrenunciável, e se dirige a todos os participantes da relação contratual, não apenas aos credores e devedores. Além disso, a sua aplicação independe de orientação expressa da legislação, por tratar-se de princípio fundamental ${ }^{63}$, o que reforça a sua aplicação nas fases pré e pós-contratual.

Como será analisado nos próximos itens, a boa-fé enquanto criadora de deveres anexos, laterais ou instrumentais desempenhou um papel fundamental na alteração dos conceitos tradicionais de obrigação, adimplemento e inadimplemento e modificou diversos paradigmas do Direito das Obrigações. Tanto isso é verdade, que, segundo parcela da doutrina brasileira, quando uma das partes contratantes deixa de cumprir deveres anexos, positivos ou negativos, esse comportamento ofende a boa-fé objetiva e caracteriza o inadimplemento do contrato $^{64}$. É o que se tem denominado de violação positiva da obrigação ou do contrato ${ }^{65}$.

Feitas essas breves considerações acerca do conceito de boa-fé objetiva, em especial sobre a sua função como fonte geradora de deveres anexos, instrumentais ou

\footnotetext{
${ }^{62}$ GODOY, Claudio Luiz Bueno de. Função social do contrato: os novos paradigmas contratuais. São Paulo: Saraiva. 2004. p. 7.

${ }^{63}$ Nesse sentido, SILVA, AGUIAR JR, LOZ MOZOS e VARELA apud SAMPAIO, Laerte Marrone de Castro. A boa-fé objetiva na relação contratual. São Paulo: Manole. 2004. p. 40.

${ }^{64}$ Nesse sentido a Conclusão n. 24 da I Jornada de Direito Civil (STJ-CJF): "Em virtude do princípio da boafé, positivado no art. 422 do novo Código Civil, a violação dos deveres anexos constitui espécie de inadimplemento, independentemente de culpa."

${ }^{65}$ NERY JUNIOR, Nelson. Contratos no Código Civil - Apontamentos gerais. In: FRANCIULLI NETO, Domingos; MENDES, Gilmar Ferreira; MARTINS FILHO, Ives Gandra da Silva (Coord.). O novo Código Civil: estudos em homenagem ao Professor Miguel Reale. São Paulo: LTr, 2003. p. 435.
} 
laterais, passaremos a analisar as alterações que a boa-fé objetiva introduziu no conceito de obrigação.

\subsection{A alteração do conceito tradicional de obrigação: a obrigação como processo não apenas dirigido ao adimplemento da prestação principal}

Com relação à origem do termo obrigação, Álvaro Villaça Azevedo aponta que o velho direito romano não conheceu o termo obligatio, que não se encontra no texto da Lei das XII Tábuas, mas apenas a expressão nexum (espécie de empréstimo), do verbo latino nectere, que significa ligar, prender, unir, atar. $\mathrm{O}$ nexum conferia ao credor o poder de exigir o cumprimento de determinada prestação. Em caso de inadimplemento, o devedor respondia com seu próprio corpo, podendo ser reduzido à condição de escravo, o que se dava por meio da chamada actio per manus iniectionem ${ }^{66}$.

A obrigação surgiu bem definida no período do Baixo Império de Roma (período compreendido entre os séculos III e V), quando não mais se admitia a execução pessoal após o advento da Lei Petélia Papíria (Lex Poetelia Papiria) no século IV a.C. Antes dessa lei, a obrigação era um vínculo meramente pessoal, sem qualquer sujeição ao patrimônio do devedor, o qual estava vinculado com seu próprio corpo. Com o progresso do conceito de obrigação, passou a sua execução, em caso do seu não cumprimento, da pessoa do devedor para o patrimônio deste ${ }^{67}$.

Moreira Alves afirma que, nas fontes romanas, existem dois textos que visam à conceituação de obrigação (obligatio) ${ }^{68}$. Um deles define a obrigação como "o vínculo

\footnotetext{
${ }^{66}$ AZEVEDO, Álvaro Villaça. Teoria geral das obrigações: responsabilidade civil. São Paulo: Atlas. 10. ed. 2004. p. 30.

${ }^{67}$ AZEVEDO, Álvaro Villaça. Teoria geral das obrigações: responsabilidade civil. São Paulo: Atlas. 10. ed. 2004. p. 31. Com a mesma orientação: “[...] os romanistas divergem sobre se a obrigação nasceu do delito (essa, a opinião da maioria) ou do contrato, mas concordam em que ela estabelecia, a princípio, não um vínculo jurídico (isto é, imaterial), mas um vínculo material, em virtude do qual o devedor respondia pela dívida com seu próprio corpo; somente depois da lei Poetelia Papiria (326 a.C.) é que o patrimônio do devedor passou a responder pelo débito, como sucede no direito moderno.” ALVES, José Carlos Moreira. Direito romano. Rio de Janeiro: Editora Forense. 14. ed., 2007. p. 378.

${ }^{68}$ Nesse sentido, Moreira Alves assevera que "nas fontes, há dois textos que visam à conceituação da obligatio. Um deles - I. III, 13, pr. - a define com relação à pessoa do devedor:
} 
jurídico ao qual nos submetemos coercitivamente, sujeitando-nos a uma prestação, segundo o direito de nossa cidade" ${ }^{, 69}$. Outra definição oriunda do direito romano, atribuída ao jurisconsulto Paulo, menciona que "a essência da obrigação não consiste em nos tornar proprietários ou em nos fazer adquirir uma servidão, mas em obrigar alguém a nos dar, fazer ou prestar alguma coisa" ${ }^{\text {70 }}$.

De acordo com Moreira Alves, os romanistas, baseando-se nas fontes acima referidas, definiram a obrigação como "um vínculo jurídico em virtude do qual o devedor é compelido a realizar uma prestação de conteúdo econômico em favor de outrem. Ao devedor, portanto, incumbiria um dever jurídico - a obligatio" ${ }^{, 1}$.

Diante da influência do direito romano, a obrigação ainda é entendida como "um vínculo jurídico em virtude do qual uma pessoa fica adstrita a satisfazer uma prestação em proveito de outra"72 ou como "o vínculo de direito pelo qual um sujeito passivo fica adstrito a dar, fazer ou não fazer alguma coisa em favor de um sujeito ativo, sob pena de, se não o fizer, espontaneamente, seu patrimônio responder pelo equivalente" 73 .

Com relação à influência do direito romano na concepção atual da obrigação, Álvaro Villaça Azevedo afirma que “as características conceituais da obrigação

Obligatio est iuris uinculum, quo necessitate adstrigimur alicuius soluendae rei secundum nostrae ciuitatis iura (A obrigação é um vínculo pelo qual estamos obrigados a pagar alguma coisa, segundo o direito de nossa cidade).

O outro - um fragmento atribuído a Paulo, e que se encontra no Digesto, XLIV, 7, 3, pr. - a focaliza quanto ao seu objeto (isto é, como veremos adiante, quanto à prestação):

Obligationum substantia non in eo consistit, ut aliquod corpus nostrum aut seruitutem nostram faciat, sed ut alium nobis obstringat ad dandum aliquid uel faciendum uel praestandum (A essência da obrigação não consiste em nos tornar proprietários ou em nos fazer adquirir uma servidão, mas em obrigar alguém a nos dar, fazer, ou prestar alguma coisa)". ALVES, José Carlos Moreira Alves. Direito romano. Rio de Janeiro: Editora Forense. 14. ed. 2007. p. 375.

${ }^{69}$ Institutas, Livro III, Título 14 apud CALIXTO, Marcelo Junqueira. Reflexões em torno do conceito de obrigação, seus elementos e suas fontes. In: TEPEDINO, Gustavo (Coord.). Obrigações: estudos na perspectiva civil-constitucional. Rio de Janeiro: Renovar. 2005. p.1.

${ }^{70}$ Digesto, Livro XLIV, Título 7, Fragmento 3. apud CALIXTO, Marcelo Junqueira. Reflexões em torno do conceito de obrigação, seus elementos e suas fontes. In: TEPEDINO, Gustavo (Coord.). Obrigações: estudos na perspectiva civil-constitucional. Rio de Janeiro: Renovar. 2005. p. 2.

${ }^{71}$ ALVES, José Carlos Moreira. Direito romano. Rio de Janeiro: Editora Forense. 14. ed. 2007. p. 375.

${ }^{72}$ GOMES, Orlando. Obrigações. 12. ed., Rio de Janeiro: Ed. Forense. 2002, p. 9.

${ }^{73}$ RODRIGUES, Sílvio. Direito civil. v. 2, 30. ed. São Paulo: Saraiva. 2002, p. 6. 
continuaram, praticamente, as mesmas, diferenciando-se a obrigação do Direito moderno pelo conteúdo econômico da prestação" ${ }^{, 74}$. Assim, o referido autor conceitua a obrigação como uma "relação jurídica transitória, de natureza econômica, pela qual o devedor fica vinculado ao credor, devendo cumprir determinada prestação pessoal, positiva ou negativa, cujo inadimplemento enseja a este executar o patrimônio daquele para satisfação de seu interesse" $" 75$.

A doutrina tradicional via no vínculo obrigacional praticamente um estado de sujeição ou subordinação do devedor, que seria o único responsável pelo adimplemento da obrigação, garantindo-o com o seu patrimônio ${ }^{76}$. No conceito clássico de obrigação, “o pólo credor tem o poder de, pelo vínculo, adstringir - verbo dicionarizado como sinônimo de submeter, subjugar, dominar ou apertar - o outro pólo, devedor, a solver a obrigação segundo a lei civil". 77

No entanto, a doutrina moderna chegou à conclusão de que essa noção de obrigação estava ultrapassada. A concepção tradicional de obrigação, consubstanciada na ideia de uma submissão do devedor ao credor, vem sendo paulatinamente abandonada em favor de um novo conceito de relação obrigacional, composto por direitos e deveres recíprocos das partes, que convergem para a consecução de um escopo comum e para atingir a finalidade contratual ${ }^{78}$.

A doutrina mais recente tem realçado o fato de que a obrigação deve ser vista sob um aspecto dinâmico ${ }^{79}$ e não estático, salientando existir uma relação jurídica

${ }^{74}$ AZEVEDO, Álvaro Villaça. Teoria geral das obrigações: responsabilidade civil. 10. ed. São Paulo: Atlas. 2004. p. 32.

${ }_{75}$ AZEVEDO, Álvaro Villaça. Teoria geral das obrigações: responsabilidade civil. 10. ed. São Paulo: Atlas. 2004. p. 33.

${ }^{76}$ CALIXTO, Marcelo Junqueira. Reflexões em torno do conceito de obrigação, seus elementos e suas fontes. In: Obrigações: estudos na perspectiva civil-constitucional. TEPEDINO, Gustavo (Coord.). Rio de Janeiro: Renovar. 2005. p.3.

${ }_{78}^{77}$ COSTA, Judith Martins, “A boa-fé no direito privado”. Ed. Revista dos Tribunais. p. 385.

78 SCHREIBER, Anderson. A tríplice transformação do adimplemento. Adimplemento substancial, inadimplemento antecipado e outras figuras. Revista Trimestral de Direito Civil. Rio de Janeiro, v. 32, out./dez 2007, p. 8-9.

${ }^{79}$ Gustavo Tepedino afirma que "modernamente, no entanto, verifica-se a insuficiência do aspecto estrutural para a compreensão da relação obrigacional, sendo indispensável examiná-la em seu aspecto dinâmico, de acordo com a função desempenhada em determinado regulamento de interesses. Entende-se assim que o 
obrigacional, que tem por conteúdo uma série de direitos e deveres de ambas as partes contratantes $^{80}$. A obrigação passa a ser vista como um processo, no qual ambas as partes e não apenas o devedor ${ }^{81}$ - devem cooperar para atingir uma finalidade, que é o adimplemento contratual e a satisfação dos interesses das partes contratantes ${ }^{82}$.

Nas palavras de Clovis V. do Couto e Silva, a expressão "obrigação como processo" objetiva destacar "o aspecto dinâmico da obrigação, as várias fases que surgem no desenvolvimento da relação obrigacional e que entre si se ligam com interdependência" 83 . A obrigação passa a ser vista como uma série de atos que se ligam entre si com interpendência, orientados a um certo fim: o adimplemento contratual ${ }^{84}$.

Nessa mesma direção, João Calvão da Silva afirma que a relação obrigacional é um processo tendente ao cumprimento (adimplemento contratual), "expressando o termo

vínculo obrigacional é complexo, pois dele defluem deveres para ambas as partes - credor(es) e devedor(es) - em direção ao adimplemento que é o seu fim, formando uma cadeia teleologicamente interligada". TEPEDINO, Gustavo; BARBOZA, Heloisa Helena; MORAES, Maria Celina Bodin de. Código Civil interpretado conforme a Constituição da República. v. I. 2. ed. rev. e atual. Rio de Janeiro: Renovar. 2007. p. 596.

${ }^{80}$ LARENZ, Karl. Derecho de obligaciones. tomo I. Trad. de Jaime Santos Briz, Madrid: Editora Revista de Derecho Privado. 1958. p. 21-22. No mesmo sentido, Pietro Perlingieri observa que "as situações subjetivas não se podem distinguir - a não ser em termos quantitativos - em ativas e passivas, já que as chamadas situações ativas compreendem também deveres gerais e específicos (obblighi) e as chamadas situações passivas contêm frequentemente alguns direitos e poderes. A relação jurídica não está na ligação entre direito subjetivo de um lado e dever, ou dever específico (obbligo), do outro. É difícil imaginar direitos subjetivos que não encontrem justificativa em situações mais complexas, das quais fazem parte também deveres, ônus, deveres específicos (obblighi), isto é, posições que, analiticamente consideradas, podem ser definidas como passivas. A relação jurídica sob o perfil estrutural é ralação entre situações complexas, que pode ser ora de simples coligação (como entre poder jurídico e interesse legítimo), ora, e são as hipóteses mais frequentes no campo do direito civil, de contraposição de conflito (como nas obrigações onde a situação de débito se contrapõe àquela de crédito)". PERLINGIERI, Pietro. O direito civil na legalidade constitucional. Trad. de Maria Cristina De Cicco. Rio de Janeiro: Renovar. 2008. p. 735.

${ }^{81}$ Marcelo Junqueira Calixto faz uma observação relevante a esse respeito: "Não se quer com isso negar que a relação jurídica obrigacional está destinada à satisfação do interesse do credor, mas enfatizar a necessidade de que este também deve cooperar na consecução deste fim”. CALIXTO, Marcelo Junqueira. Reflexões em torno do conceito de obrigação, seus elementos e suas fontes. In: TEPEDINO, Gustavo (Coord.). Obrigações: estudos na perspectiva civil-constitucional. Rio de Janeiro: Renovar. 2005. p.6.

${ }^{82}$ AGUIAR JR., Ruy Rosado. Extinção dos contratos por incumprimento do devedor (resolução). Rio de Janeiro: Aide. 1991. p. 18.

${ }^{83}$ SILVA, Clóvis do Couto e. A obrigação como processo. Rio de Janeiro: Editora FGV, 2006. p. 20.

${ }^{84} \mathrm{O}$ referido autor ainda complementa que "os atos praticados pelo devedor, assim como os realizados pelo credor, repercutem no mundo jurídico, nele ingressam e são dispostos e classificados segundo uma ordem, atendendo-se aos conceitos elaborados pela teoria do direito. Esses atos, evidentemente, tendem a um fim. E é precisamente a finalidade [satisfação do interesse do credor e adimplemento contratual] que determina a concepção da obrigação como processo". SILVA, Clóvis do Couto e. A obrigação como processo. Rio de Janeiro: Editora FGV. 2006. p. 20-21. 
processo um encadeamento de actos destinados a um certo fim - no nosso caso o cumprimento". 85

A obrigação não é mais vista como "a estéril junção de dois momentos estáticos - o nascimento e o adimplemento da obrigação" ${ }^{86}$, mas sim como um processo contínuo e dinâmico no qual as partes devem se comportar de modo leal, probo e cooperativo, para que a obrigação seja adimplida com o máximo proveito aos contratantes.

A obrigação como processo exige como substrato a cooperação do alter (outro), seja ele credor, seja devedor ou terceiro, e faz com que seja superado o paradigma tradicional do direito das obrigações, fundado na valorização jurídica da vontade humana (princípio da autonomia da vontade), e inaugurado um novo paradigma para o direito obrigacional, baseado na boa-fé objetiva ${ }^{87}$.

O conteúdo da relação obrigacional deixa de ser resultado apenas da vontade das partes e passa a ser determinado também pela boa-fé objetiva, que impõe às partes deveres anexos de conduta dirigidos à exata satisfação dos interesses envolvidos na relação obrigacional $^{88}$.

O princípio da boa-fé opera, aqui, como um "mandamento de consideração", para que as partes cooperem para atingir a finalidade que ensejou o surgimento daquela relação contratual concreta ${ }^{89}$. Nesse novo paradigma, "a boa-fé atua como fonte de integração do conteúdo contratual, determinando a sua otimização independentemente da

85 SILVA, João Calvão da. Cumprimento e sanção pecuniária compulsória. Coimbra: Livraria dos Advogados Editora. 1987. p. 70.

${ }^{86}$ FURTADO, Gabriel Rocha. Mora e inadimplemento substancial. São Paulo: Atlas. 2014. p. 9.

${ }^{87}$ COSTA, Judith Martins. A boa-fé no direito privado. Ed. Revista dos Tribunais. p. 394-395. Claudio Luiz Bueno de Godoy observa que "[...] cede lugar o dogma da vontade - até então fonte motriz do estabelecimento das relações contratuais, base do conceito absoluto, ou quase, da autonomia negocial - à admissão de que o contrato encerra também uma dimensão social, que vai além da esfera jurídica das partes contratantes e, mais, que resulta de fontes que, a rigor, não se circunscrevem ao quanto declarado no ajuste". GODOY, Claudio Luiz Bueno de. Função social do contrato: os novos paradigmas contratuais. São Paulo: Saraiva. 2004. p. 4.

${ }^{88}$ TERRA, Aline de Miranda Valverde. Inadimplemento anterior ao termo. Rio de Janeiro: Renovar. 2009. p. 38.

${ }^{89}$ SILVA, Clóvis do Couto e. A obrigação como processo. Rio de Janeiro: Editora FGV. 2006. p. 34. 
regulação voluntaristicamente estabelecida"90. Há, assim, uma nítida expansão das fontes dos deveres obrigacionais, colocando-se a boa-fé objetiva ao lado da vontade na criação de tais deveres.

Nas palavras de Clóvis do Couto e Silva:

a dogmática do século passado tinha por centro a vontade, de forma que para os juristas daquela época, todos os deveres dela resultavam. Em movimento dialético e polêmico poder-se-ia chegar à conclusão oposta, isto é, a de que todos os deveres resultassem da boa-fé. Mas a verdade está no centro: há deveres que promanam da vontade e outros que decorrem da incidência do princípio da boafé e da proteção jurídica de interesses. ${ }^{91}$

Assim, o vínculo jurídico que liga o credor e o devedor (aspecto externo da obrigação) passa a coexistir com um complexo de direitos e deveres decorrentes do princípio da boa-fé objetiva (aspecto interno), o que permite que a relação obrigacional seja integrada não apenas pelos "fatores e circunstâncias que decorrem do modelo tipificado na lei ou os que nascem da declaração de vontade, mas, por igual, fatores extravoluntarísticos, atinentes à concreção de princípios e standards de cunho social e constitucional" $" 92$.

A obrigação passa a ser uma "totalidade" 93 , entendida não apenas como uma prestação isolada, mas como uma relação jurídica total, que compreende os deveres de prestação e de conduta, bem como deveres instrumentais, laterais ou anexos, os quais visam ao perfeito adimplemento contratual e à satisfação do interesse das partes. A esse respeito, Judith Martins-Costa pondera que:

[...] no vínculo obrigacional considerado como uma totalidade, como um complexo de direitos (direitos de crédito, direitos formativos), deveres (principais e secundários, laterais e instrumentais), sujeições, pretensões, obrigações, exceções, ônus jurídicos, legítimas expectativas etc., visualiza-se, como já referi, além do aspecto externo, o aspecto interno, vale dizer, aquele conjunto inseparável de elementos que coexiste, material e complessivamente,

\footnotetext{
${ }^{90}$ COSTA, Judith Martins. A boa-fé no direito privado. Ed. Revista dos Tribunais. p. 440.

${ }^{91}$ SILVA, Clóvis do Couto e. A obrigação como processo. Rio de Janeiro: Editora FGV. 2006. p. 38.

${ }^{92}$ COSTA, Judith Martins. A boa-fé no direito privado. Ed. Revista dos Tribunais. p. 395.

${ }^{93}$ LARENZ, Karl. Derecho de obligaciones. Trad. de Jaime Santos Briz. t. 1. Madrid: Editorial Revista de Derecho Privado. 1958. p. 37.
} 
no vínculo que liga credor e devedor, aí inclusos os elementos consistentes às suas fontes e aos seus limites ${ }^{94}$.

No mesmo sentido se posiciona Menezes Cordeiro:

A complexidade intra-obrigacional traduz a ideia de que o vínculo obrigacional abriga, no seu seio, não um simples dever de prestar, simétrico a uma prestação creditícia, mas antes vários elementos jurídicos dotados de autonomia bastante para, de um conteúdo unitário, fazerem uma realidade composta. ${ }^{95}$

É sob esse prisma que o objeto da obrigação e os conceitos de adimplemento e inadimplemento serão analisados.

\subsection{A funcionalização da relação obrigacional}

O conceito clássico de obrigação, que a visualiza apenas como um vínculo jurídico em virtude do qual o credor deverá prestar algo ao devedor, dá ênfase somente ao aspecto externo e estrutural da relação obrigacional, qual seja, o definido pelos seus elementos, os sujeitos, o objeto e o vínculo de sujeição que liga o devedor ao credor, o crédito e a dívida.

Na acepção clássica de obrigação, a análise da função jurídica tem uma importância secundária, surgindo excepcional e pontualmente naquelas hipóteses em que a lei expressamente determinar que o interesse do credor deve ser considerado, como acontece no parágrafo único do artigo 395 do Código Civil, segundo o qual o critério para

\footnotetext{
${ }^{94}$ COSTA, Judith Martins. A boa-fé no direito privado. Ed. Revista dos Tribunais. p. 394-395.

${ }^{95}$ MENEZES Cordeiro, António Manuel da Rocha. Da boa-fé no direito civil. Coimbra: Almedina. 2011. Giovanni Ettore Nanni também afirma que "se na perspectiva clássica a obrigação se esgota no dever de prestar e no correlato direito de exigir ou pretender a prestação, na doutrina moderna ela é compreendida numa acepção globalizante da situação jurídica creditícia, apontando, ao lado dos deveres de prestação tanto deveres principais de prestação, como deveres secundários - , os deveres laterais, além de direitos potestativos, sujeições, ônus jurídicos, expectativas jurídicas, etc." NANNI, Giovanni Ettore. O dever de cooperação nas relações obrigacionais à luz do princípio constitucional da solidariedade. In: NANNI, Giovanni Ettore (Coord.). Temas relevantes do direito civil contemporâneo: reflexões sobre os cinco anos do Código Civil. São Paulo: Atlas. 2008. p. 300.
} 
aferir a possibilidade de purgação da mora por parte do devedor reside na manutenção da utilidade da prestação para o credor $^{96}$.

Contudo, a doutrina mais moderna tem reconhecido a insuficiência de uma análise meramente estrutural da obrigação, destacando que a relação obrigacional também deve levar em consideração as finalidades que as partes perseguem com o adimplemento da obrigação ${ }^{97}$.

Com efeito, a própria razão para o ordenamento tutelar uma determinada relação obrigacional deve passar pela apreciação da legitimidade das suas finalidades, exigindo-se que o interesse do credor no adimplemento daquela obrigação seja digno de tutela. Não se pode admitir que o devedor concorde em se obrigar a algo se não for para atender a um interesse considerado legítimo e merecedor de tutela à luz do direito ${ }^{98}$.

\section{Nessa direção Pietro Perlingieri:}

L'interesse del creditore è, innanzitutto, indispensabile per la stessa nascita del rapporto. Altrimenti non si giustificherebbe neppure l'imposizione al debitore di un vinculo che ne limiti e ne comprima la libertà; il nostro sistema, infatti, non ne ammette restrizioni, se non in ragione ed in funzione della realizzazione di interessi altrui considerati preminenti. ${ }^{99}$

Sob essa perspectiva funcional, a relação obrigacional passou a ser vista como um conjunto de deveres - não só os deveres principais, mas também os deveres laterais decorrentes da boa-fé objetiva - impostos às partes para o atingimento da finalidade

\footnotetext{
${ }^{96}$ KONDER, Carlos Nelson; RENTERÍA, Pablo. A funcionalização das Relações Obrigacionais: interesse do credor e patrimonialidade da prestação. In: TEPEDINO, Gustavo; FACHIN, Luiz Edson (Org.). Diálogos sobre Direito Civil. vol II, Rio de Janeiro: Renovar. 2007. p. 267.

${ }^{97}$ KONDER, Carlos Nelson; RENTERÍA, Pablo. A funcionalização das Relações Obrigacionais: interesse do credor e patrimonialidade da prestação. In: TEPEDINO, Gustavo; FACHIN, Luiz Edson (Org.). Diálogos sobre Direito Civil. v. II, Rio de Janeiro: Renovar. 2007. p. 267.

${ }^{98}$ KONDER, Carlos Nelson; RENTERÍA, Pablo. A funcionalização das Relações Obrigacionais: interesse do credor e patrimonialidade da prestação. In: TEPEDINO, Gustavo; FACHIN, Luiz Edson (Org.). Diálogos sobre direito civil. v. II. Rio de Janeiro: Renovar. 2007. p. 267.

99 PERLINGIERI. Manuale di diritto civile. Napoli: ESI, 1997, p. 348. Em tradução livre: “O interesse do credor é antes de tudo fundamental para o nascimento da relação obrigacional. Caso contrário, não se justifica nem mesmo a imposição ao devedor de um vínculo que limite ou comprima a liberdade; nosso sistema, na verdade, não admite restrições, se não em razão e em função da realização de interesses outros considerados primordiais."
} 
buscada por meio da relação obrigacional, consistente na satisfação do interesse do credor. É essa finalidade comum buscada pelas partes que confere unidade a todos os direitos, deveres e situações jurídicas que compõem a relação obrigacional.

A esse respeito, Fernando Noronha afirma que "os elementos constitutivos da relação obrigacional não são suficientes para termos uma ideia perfeita desta. Para cabal compreensão do conceito de obrigação, é preciso ter em conta para que esta serve. Todo direito tem uma função, ou finalidade, que justifica a sua existência e tutela jurídica”, concluindo que "a finalidade da obrigação é a satisfação de um interesse do credor, mas que tem de ser legítimo, isto é, sério e útil"100.

Nessa linha, é possível afirmar que a relação obrigacional compreende variados poderes e deveres de ambas as partes, que se vão constituindo ao longo da relação obrigacional como algo que se "encadeia e se desdobra em relação ao adimplemento, à satisfação dos interesses do credor" ${ }^{\prime 101}$.

Nas palavras de Karl Larenz:

[...] por el hecho mismo de que en toda relación de obligación late el fin de la satisfacción del interés en la prestación del acreedor, puede y debe considerarse la relación de obligación como un proceso. Está desde un principio encaminada a alcanzar un fin determinado y a extinguirse con la obtención de este fin. ${ }^{102}$

À luz dessa visão funcionalizada da relação obrigacional, a obrigação deixa de ser concebida com um fim em si mesmo e passa a ser vista como "um meio, um instrumento técnico-jurídico criado por lei ou predisposto pelas partes para a satisfação de

\footnotetext{
${ }^{100}$ NORONHA, Fernando. Direito das obrigações. v. I. São Paulo: Saraiva. 2013. p. 36.

${ }^{101}$ SILVA, Clóvis do Couto e. A obrigação como processo. Rio de Janeiro: Editora FGV. 2006. p. 17.

102 LARENZ, Karl. Derecho de obligaciones. tomo I. Trad. de Jaime Santos Briz, Madrid: Editora Revista de Derecho Privado. 1958. p. 39. Em tradução livre: “[...] pelo fato de que toda a relação obrigacional tem como fim a satisfação do interesse do credor, a relação obrigacional pode e deve ser considerada como processo. Está desde o início encaminhada a alcançar um fim determinado e a extinguir-se com a obtenção desse fim."
} 
certo interesse" um instrumento de cooperação social para a satisfação de certo interesse do credor"104.

A doutrina moderna entende, assim, que a "relação obrigacional está colimada à satisfação do interesse do credor, nela encontrando o seu sentido final e existencial" e que a obrigação "nasce para satisfazer o mais completa e adequadamente o interesse do credor na prestação" ${ }^{\prime 105}$. Todavia, a afirmação de que a obrigação nasce para satisfazer o interesse do credor não quer dizer que a funcionalização da relação obrigacional importa em desconsideração absoluta do interesse do devedor, conforme observa Pietro Perlingieri:

L'attuazione del rapporto obbligatorio, oltre all'interesse del creditore, "può" realizzare anche interessi giuridicamente rilevanti del debitore. Ovviamente una considerazione prioritaria e prevalente deve essere riservata all'interesse creditore $[\ldots] .{ }^{106}$

Entendemos que deve ser interpretada com reservas a orientação clássica segundo a qual a obrigação teria na satisfação do interesse do credor o seu escopo e a sua única razão de ser. É mais apropriado afirmar que a funcionalização da relação obrigacional impõe o seu reconhecimento como mecanismo de satisfação do interesse das partes, embora o interesse do credor assuma posição mais relevante na maioria dos casos. A concepção moderna de obrigação amplia o espectro de interesses que devem ser satisfeitos com a relação obrigacional, de modo a abarcar os interesses legítimos perquiridos por ambas as partes ${ }^{107}$.

Fernando Noronha realiza preciosa síntese sobre a questão:

\footnotetext{
${ }^{103}$ VARELA, João de Mattos Antunes. Das obrigações em geral. Coimbra: Almedina. 1970. p. 20.

${ }^{104}$ KONDER, Carlos Nelson; RENTERÍA, Pablo. A funcionalização das relações obrigacionais: interesse do credor e patrimonialidade da prestação. Diálogos sobre Direito Civil. In: TEPEDINO, Gustavo; FACHIN, Luiz Edson (Org.). Diálogos sobre direito civil. V. II, Rio de Janeiro: Renovar. 2007. p. 267.

105 SILVA, João Calvão da. Cumprimento e Sanção Pecuniária Compulsória. Coimbra: Livraria dos Advogados Editora. 1987. p. 67.

106 PERLINGIERI. Manuale di diritto civile. Napoli: ESI. 1997. p. 220. Em tradução livre: “A relação obrigacional, além do interesse do credor, 'pode' realizar também interesses do devedor juridicamente relevante. Obviamente, deve-se ter em consideração prioritária e prevalente o interesse do credor [...]”.

${ }^{107}$ TERRA, Aline de Miranda Valverde. Inadimplemento anterior ao termo. Rio de Janeiro: Renovar. 2009. p. 23.
} 
Toda ação humana visa uma finalidade. A obrigação também tem uma: a satisfação de um interesse legítimo do credor. [...]

As obrigações, porém, não têm por finalidade realizar unicamente uma finalidade individual, egoística, do credor; ao lado desta, qualquer obrigação, na medida em que é objeto de tutela jurídica, tem também uma finalidade social, porque toda norma jurídica visa 'fins sociais' e atende 'exigências do bem comum', como ficou expresso no art. $5^{\circ}$ da Lei de Introdução às Normas do Direito Brasileiro (até 2010 designada de Lei de Introdução ao Código Civil Brasileiro). Ora, se conjugarmos esses dois objetivos, individual e social, poderíamos dizer que toda obrigação tem de satisfazer um interesse legítimo do credor.

[...] é preciso ter presente que na maioria das relações obrigacionais (e em especial nas nascidas dos contratos chamados de bilaterais: cf. art. 476) existem duas partes, que são, uma em relação à outra, simultaneamente parte credora e parte devedora. Nestes casos, haverá que considerar os interesses legítimos de ambas as partes. ${ }^{108}$

É essa análise funcional e finalística que deverá orientar todo o desenvolvimento da relação obrigacional, desde a sua formação até a sua extinção, servindo de parâmetro para a valoração do comportamento das partes - que, pela cláusula geral da boa-fé objetiva, são chamadas a colaborarem mutuamente para a plena realização dos seus interesses - e para uma releitura dos conceitos e institutos do direito obrigacional.

\subsection{O alargamento do objeto da obrigação}

Prevalece na doutrina a concepção personalista da obrigação, de acordo com a qual o objeto da obrigação consiste sempre em um ato humano, em uma prestaçãocomportamento $^{109}$. Na doutrina tradicional, o objeto da obrigação consiste no comportamento do devedor que executa a prestação principal e, por via de consequência, o credor tem direito a exigir o comportamento do devedor relacionado ao dever de prestação principal. No entanto, essa definição tradicional de prestação não está alinhada com a atual concepção de obrigação porque restringe o comportamento do devedor exclusivamente à realização da prestação principal $^{110}$.

\footnotetext{
${ }^{108}$ NORONHA, Fernando. Direito das obrigações. v. I. São Paulo: Saraiva. 2013. p. 40.

${ }^{109}$ Fernando Noronha afirma que "a prestação debitória é a conduta ou comportamento do devedor, a atividade ou abstenção de atividade que é essencial para a realização do interesse do credor. Antunes Varela [VARELA, João de Matos Antunes. Direito das obrigações. 2v. São Paulo: Forense. 1977-1979.] caracteriza-a muito bem como 'a ação ou omissão a que o devedor fica adstrito e que o devedor tem o direito de exigir"”. NORONHA, Fernando. Direito das obrigações. v. I. São Paulo: Saraiva. 2013. p. 55.

${ }^{110}$ TERRA, Aline de Miranda Valverde. Inadimplemento anterior ao termo. Rio de Janeiro: Renovar. 2009. p. 51-52.
} 
Como analisado no item anterior, a relação obrigacional não constitui um fim em si mesmo, a sua razão de ser consiste na satisfação dos interesses das partes, mais concretamente no interesse do credor ${ }^{111}$. Desta maneira, sob o ponto de vista do credor, o comportamento do devedor (a prestação) não é desejado em si mesmo, mas apenas como instrumento de realização do seu interesse. Destaca-se, assim, o caráter instrumental que é atribuído à obrigação do devedor.

\section{Conforme observa Rosario Nicoló:}

[...] si sottolinea, d'altra parte, la funzione essenzialmente strumentale che è assegnata all'obbligo del debitore rispetto alla realizzazione dell' interesse del creditore, dal punto di vista strettamente giuridico, e non soltanto da quello economico-sociale. $^{112}$

Prevalece na doutrina atual que "toda obrigação se volta a proporcionar, com o adimplemento, o resultado útil que consubstancia a satisfação do interesse do credor"113. Daí entender-se que o objeto da obrigação passa a ser visto como o comportamento do devedor dirigido à realização do interesse do credor, que se alcança por meio do atingimento do resultado útil esperado de uma determinada relação obrigacional. Assim, ao credor impõe-se "a realização do plano obrigacional concretamente traçado pelas partes", para proporcionar ao credor "o resultado útil programado"114.

O interesse que a prestação deve satisfazer é o interesse típico e concreto ${ }^{115}$, isto é, aquele interesse que as partes negociaram, regularam e pretenderam alcançar por

${ }^{111}$ NORONHA, Fernando, Direito das obrigações. v. I. São Paulo: Saraiva. 2013. p. 39.

112 NICOLÒ, Rosario. Adempimento (diritto civile). Enciclopedia del diritto. v. I, Varese: Giuffrè. p. 555. Em tradução livre: "sublinha-se, por outro lado, a função essencialmente instrumental que é atribuída à obrigação do devedor para com a realização do interesse do credor, do ponto de vista estritamente jurídico, e não somente econômico-social."

${ }^{113}$ KONDER, Carlos Nelson; RENTERÍA, Pablo. A funcionalização das relações obrigacionais: interesse do credor e patrimonialidade da prestação. In: TEPEDINO, Gustavo; FACHIN, Luiz Edson (Org.). Diálogos sobre direito civil. v. II, Rio de Janeiro: Renovar. 2007. p. 273.

${ }^{114}$ TERRA, Aline de Miranda Valverde. Inadimplemento anterior ao termo. Rio de Janeiro: Renovar. 2009. p. 53.

${ }^{115}$ Sobre o tema, Judith Martins-Costa assim se pronuncia: "Trata-se de um interesse objetivado, e de uma utilidade objetiva, que devem ser recortados à vista da operação econômica em causa, é dizer: do que as partes dispuseram no comum regulamento de interesses, cabendo ao juiz apreender o interesse e a utilidade com base na natureza da prestação e das regras comuns da experiência (CPC, art. 335)". COSTA, Judith Martins. O fenômeno da supracontratualidade e o princípio do equilíbrio: inadimplemento de deveres de 
meio de uma relação obrigacional específica. A prestação deve ser objetivamente idônea a satisfazer o interesse típico e concreto do credor naquele vínculo contratual específico.

Afirma-se que o interesse que deve ser satisfeito se relaciona intimamente com o fim do negócio jurídico, concebido a partir da teoria da causa concreta ${ }^{116}$ e do fim objetivamente perseguido pelo credor no negócio jurídico em concreto, que deve ser perceptível à outra parte. A análise da satisfação do interesse do credor impõe o exame do fim que o credor buscou com aquele tipo contratual específico e com aquela relação obrigacional em concreto. A desatenção a esse fim poderá tornar o "adimplemento insatisfatório e imperfeito" $" 117$.

A título de exemplo, mencione-se o caso do comerciante que contrata a fabricação e colocação de letreiro luminoso para efeitos de publicidade (divulgação do seu produto), cujo interesse claramente abrange a instalação de anúncio em local adequado à sua finalidade, ou seja, em local de intenso tráfego. Na hipótese da contraparte fabricar o anúncio conforme contratado, mas instalá-lo em local pouco frequentado, o anúncio terá reduzido ou nenhum reflexo na venda do produto. Nesse caso, a empresa contratada não poderá considerar o adimplemento como satisfatório, apesar da convenção não determinar

proteção (violação positiva do contrato) e deslealdade contratual em operação de descruzamento acionário. Revista Trimestral de Direito Civil. Rio de Janeiro, n. 26, abr./jun. 2006, p. 224.

116 Segundo Antônio Junqueira de Azevedo, o termo "causa" possuí mais de um significado. Causa, no campo dos negócios jurídicos, pode significar causa-fato jurídico (causa efficiens); o motivo, quer psicológico (causa impulsiva), quer objetivo (causa-justa-causa); a causa da juridicidade dos atos jurídicos (civilis ou naturalis); a causa de atribuição patrimonial (ou de atribuição de direitos); e a causa do negócio jurídico (causa finalis). Com relação ao significado de causa final, o autor complementa que há uma duplicidade de sentidos: "No significado de causa final, há, porém, ainda, uma duplicidade. Se se adota a concepção de Capitant, ou outra próxima, em que causa é o fim que resulta objetivamente do negócio, a causa do negócio é a 'causa concreta', o fim de cada negócio individualizado. Se se adota a concepção de causa-função, trata-se da 'causa abstrata', causa típica. Ora, por uma questão de clareza, é preferível deixar a expressão causa final reservada a somente um desses significados, de preferência o último, em que a palavra 'causa' está mais generalizada e onde é de mais difícil substituição. No outro significado, a causa concreta é, na verdade, o 'fim do negócio jurídico'. Esta é a melhor expressão”. Para um estudo mais detalhado acerca da questão, vide: AZEVEDO, Antonio Junqueira. Negócio jurídico e declaração negocial: noções gerais e formação de declaração negocial. Tese apresentada para obtenção de título de professor titular da Universidade de Direito do Largo São Francisco. São Paulo. 1986. p. 121-129.

${ }^{117}$ SILVA, Clóvis do Couto e. A obrigação como processo. Rio de Janeiro: Editora FGV. 2006. p. 41. 
especificamente onde o anúncio deveria ser colocado, porque não foi satisfeito o interesse do credor com aquela relação obrigacional. ${ }^{118}$

Acrescente-se que a doutrina atribui relevância à finalidade perseguida pelo credor do ponto de vista objetivo, afastando do conceito de interesse os motivos íntimos e arbitrários que levaram o credor a estabelecer uma determinada relação jurídica, uma vez que esses normalmente não se manifestam de uma forma socialmente visível ${ }^{119}$. Clóvis do Couto e Silva menciona, inclusive, que o interesse que deve ser satisfeito não é "algo psicológico, mas [...] um plus que integra o fim da atribuição e que está com ele intimamente relacionado" ${ }^{120}$, ou seja, que está vinculado com o fim do negócio jurídico.

Diante desse cenário, conclui-se que o objeto da obrigação não é mais algo em si, mas algo que passa a ter uma função, consistente na satisfação do interesse típico e concreto do credor naquele vínculo contratual específico, do resultado útil programado ${ }^{121}$. A prestação passa, assim, a ser vista sob uma perspectiva funcionalizada e finalística.

A esse respeito, é importante destacar que o fato da prestação passar a ser entendida como o comportamento do devedor dirigido à realização do interesse típico e concreto do credor - visão funcionalizada - conduz à necessária reavaliação do comportamento do devedor e, consequentemente, à alteração e ao alargamento da estrutura do objeto obrigacional.

A execução da prestação principal, por si só, passa a não ser considerada capaz de atender ao interesse objetivo e concreto do credor. A sua satisfação pressupõe, igualmente, uma "colaboração intersubjetiva" e a observância dos deveres de conduta impostos pela boa-fé objetiva, que exige do devedor "todos os comportamentos razoáveis

\footnotetext{
${ }^{118}$ O exemplo é de SILVA, Clóvis do Couto e. A obrigação como processo. Rio de Janeiro: Editora FGV. 2006. p. 41.

${ }^{119}$ No mesmo sentido, concluiu-se na III Jornada de Direito Civil, realizada pela Câmara de Constituição e Justiça, em novembro de 2004, em seu enunciado 162: “A inutilidade da prestação que autoriza a recusa da prestação por parte do credor deverá ser aferida objetivamente, consoante o princípio da boa-fé e a manutenção do sinalagma, e não de acordo com o mero interesse subjetivo do credor."

${ }^{120}$ SILVA, Clóvis do Couto e. A obrigação como processo. Rio de Janeiro: Editora FGV. 2006. p. 41.

${ }^{121}$ FACHIN, Luiz Edson. Teoria crítica do direito civil à luz do novo Código Civil brasileiro. 2. ed. rev. e atual. Rio de Janeiro: Renovar. 2003. p. 94.
} 
para a efectiva satisfação do interesse do credor, não se contentando, simplesmente, com um cumprimento meramente formal" ${ }^{\prime 22}$.

Somente o comportamento do devedor dirigido concomitantemente à execução da prestação principal, bem como dos deveres de conduta anexos impostos pela boa-fé objetiva, permitirá a plena satisfação do interesse objetivo e concreto do credor e o atingimento do resultado útil programado. Nesse sentido, passa-se a entender a prestação como uma prestação satisfativa ${ }^{123}$.

A funcionalização do objeto da prestação acaba por alterar a sua estrutura. Como a prestação deve ser capaz de realizar perfeitamente o interesse do credor e esse interesse não se satisfaz somente com a realização do dever principal de prestação, os deveres de conduta impostos pela boa-fé devem ser incluídos na estrutura do objeto da relação obrigacional. Assim, o objeto da obrigação passa a ser determinado pela vontade das partes, pela sistemática obrigacional e pelo princípio da boa-fé objetiva.

Destaque-se que a ampliação do objeto da obrigação não importa em multiplicidade de prestações. Apesar das diversas condutas que integram a prestação (decorrentes do dever primário de prestação e dos deveres de conduta anexos impostos pela boa-fé), ela se apresenta como uma unidade, haja vista que apenas o comportamento formado pelo conjunto de condutas devidas é capaz de produzir o resultado útil programado $^{124}$.

A funcionalização do objeto da prestação (busca pelo resultado útil programado) assegura, assim, a unidade da prestação. Por exemplo, em um contrato de distribuição, além do dever principal de distribuir as mercadorias em uma determinada área por um determinado período, o distribuidor também terá os deveres acessórios de divulgar a sua marca, ampliar o market share do produto naquela área, armazenar os produtos até a

\footnotetext{
122 MENEZES CORDEIRO, António. Direito das obrigações. v. I, reimp. 1980. Lisboa: Associação Acadêmica da Faculdade de Direito de Lisboa. 2001. p. 148-149.

${ }^{123}$ TERRA, Aline de Miranda Valverde. Inadimplemento anterior ao termo. Rio de Janeiro: Renovar. 2009. p. 64.

${ }^{124}$ TERRA, Aline de Miranda Valverde. Inadimplemento anterior ao termo. Rio de Janeiro: Renovar. 2009. p. 64.
} 
sua efetiva revenda, transportá-los até os seus clientes e revendedores, etc. No entanto, apesar de serem exigidas do devedor uma série de condutas, tem-se que é única a prestação devida pelo devedor, consistente na distribuição das mercadorias.

Acrescente-se que a prestação é una ainda que a execução do dever de prestação abranja várias operações materiais. É possível que, no iter do desenvolvimento da relação obrigacional, exija-se do devedor a execução de uma série de atos que devem ser executados (ou omitidos) para que a prestação seja adimplida e o interesse do credor seja satisfeito. Existe, nesses casos, um conjunto de deveres instrumentais que objetivam viabilizar o adimplemento.

A satisfação dos interesses do credor "exige não apenas a conduta final de execução do vínculo, mas antes, e com a mesma veemência, exige as condutas adequadas ao preparo e viabilização da fase conclusiva da prestação satisfativa" ${ }^{, 25}$. Por exemplo, o empreiteiro que se obriga a construir um edifício se obriga também a construir a rede de esgotos, preparar a instalação elétrica, atestar a qualidade dos materiais que serão utilizados na construção, etc.

Em suma, a incidência de deveres de conduta na relação obrigacional acarretou o alargamento do objeto da obrigação, que não pode mais ser concebido apenas como o comportamento do devedor que executa a prestação principal. Em seu lugar, consolida-se a ideia de que o objeto da prestação abarca tanto os deveres de prestação (principal e secundários) como os deveres laterais decorrentes da boa-fé objetiva.

Nesse sentido, somente o comportamento do devedor que observa e cumpre todos esses deveres é capaz de realizar a função do objeto da obrigação: a satisfação do interesse objetivo e concreto do devedor. Outrossim, apesar de diversos os deveres impostos ao devedor, a prestação continua a ser uma unidade, e apenas o comportamento que execute todos os deveres será capaz de produzir o resultado útil programado.

${ }^{125}$ TERRA, Aline de Miranda Valverde. Inadimplemento anterior ao termo. Rio de Janeiro: Renovar. 2009. p. 65-66. 
Feita essa análise sobre a moderna concepção de obrigação como um processo, passaremos a examinar quais alterações foram promovidas nos tradicionais conceitos de adimplemento e inadimplemento.

\subsection{A alteração do conceito de adimplemento}

$$
\text { O adimplemento }{ }^{126} \text { encerra o "efeito cabedal"" das obrigações, o "mais }
$$

natural" dentre os meios de extinção das obrigações. No direito romano, o adimplemento (ou pagamento) era considerado a prestação daquilo que está na obrigação (solutio est

\footnotetext{
${ }^{126}$ Sobre o termo adimplemento, confiram-se os ensinamentos de Álvaro Villaça Azevedo: "É bom fixar o sentido técnico-jurídico do vocábulo pagamento, pois o primeiro pensamento que vem à mente, no significado popular, é o que seja ele a prestação de uma importância em dinheiro. Essa a significação mais estrita da palavra, popular, vulgar. Na acepção mais ampla, entende-se pagamento como toda e qualquer maneira de extinção obrigacional. Até a prescrição estaria enquadrada nesta última hipótese. Já, em sentido técnico, na ciência jurídica, pagamento é implemento, o adimplemento, o cumprimento, a execução normal da obrigação." AZEVEDO, Álvaro Villaça. Teoria geral das obrigações: responsabilidade civil. 10. ed. São Paulo: Atlas, 2004. p. 128. No mesmo sentido: “[...] embora seja empregado, na linguagem corrente, para designar apenas a entrega de prestação em dinheiro, a doutrina reserva ao conceito de pagamento sentido técnico preciso, definindo-o como a execução voluntária da prestação devida ao credor, no tempo, no lugar e na forma previstos no título constitutivo da obrigação. O pagamento pode ser assim considerado como o fim normal da obrigação, sua vocação natural, qualquer que seja a res debita" TEPEDINO, Gustavo; BARBOZA, Heloisa Helena; MORAES, Maria Celina Bodin de. Código Civil interpretado conforme a Constituição da República. v. I. 2. ed. rev. e atual. Rio de Janeiro: Renovar, 2007. p. 596.

${ }^{127}$ NONATO, Orosimbo. Curso de obrigações. v. I. Rio de Janeiro: Forense. 1959. p. 9.
} 
praestatio eius quod in obligatione est $)^{128}$. Na perspectiva tradicional, o adimplemento vem definido como "o efetivo cumprimento da prestação" 129 , ou ato pelo qual "recebe o credor o que lhe é devido" $" 130$.

O foco dessa concepção tradicional se volta para o aspecto estrutural do adimplemento, correspondente ao cumprimento da prestação principal. No entanto, a estreiteza e a simplicidade dessa concepção comprometem a compreensão da relação obrigacional como uma realidade complexa, na qual também incidem os deveres anexos de conduta impostos pela boa-fé objetiva, e cujo escopo reside na satisfação dos interesses típicos e concretos das partes contratantes.

O alargamento do objeto da obrigação impõe a superação da tradicional concepção de adimplemento, segundo a qual este se perfaz com o simples cumprimento da prestação principal. Atualmente, o adimplemento deve ser entendido como "o cumprimento da prestação concretamente devida, presente a realização dos deveres derivados da boa-fé que se fizeram instrumentalmente necessários para o atendimento satisfatório do escopo da relação, em acordo ao seu fim e às circunstâncias concretas"131. O devedor terá que cumprir não só a prestação principal, mas uma série de outros deveres anexos para que haja um adimplemento perfeito.

Conforme destaca Anderson Schreiber, "reconhece-se que a obrigação transcende, em muito, o dever consubstanciado na prestação principal" e "avultam, neste sentido, em importância os chamados deveres anexos ou tutelares, que se embutem na regulamentação contratual, na ausência ou mesmo em contrariedade à vontade das partes, impondo comportamentos que vão muito além da literal execução da prestação principal" ${ }^{, 132}$.

\footnotetext{
${ }^{128}$ AZEVEDO, Álvaro Villaça. Teoria geral das obrigações: responsabilidade civil. 10. ed. São Paulo: Atlas. 2004. p. 128.

${ }^{129}$ GOMES, Orlando. Obrigações. Rio de Janeiro: Forense. 2000. p. 88.

${ }^{130}$ CHAVES, Antonio. Tratado de direito civil. v. 2. tomo 1. São Paulo: Revista dos Tribunais. 1982. p. 157.

${ }^{131}$ MARTINS-COSTA, Judith. Comentários ao novo Código Civil: do inadimplemento das obrigações. v. V. tomo 2. Rio de Janeiro: Forense. 2003. p. 67.

132 SCHREIBER, Anderson. A tríplice transformação do adimplemento. Adimplemento substancial, inadimplemento antecipado e outras figuras. Revista Trimestral de Direito Civil. Rio de Janeiro, v. 32, out./dez 2007, p. 8-9.
} 
Judith Martins Costa também destaca que o adimplemento não se resume apenas aos interesses envolvidos direta e indiretamente na prestação principal, pois o adimplemento constitui "o cumprimento da prestação concretamente devida, presente a realização dos deveres derivados da boa-fé que se fizerem instrumentalmente necessários para o atendimento satisfatório do escopo da relação, em acordo ao seu fim e às suas circunstâncias concretas" $" 133$. O adimplemento compreende, assim, a atividade retratada na prestação principal e todos os deveres anexos necessários à entrega da prestação devida ${ }^{134}$.

O adimplemento não se subordina apenas à execução da prestação principal, mas depende, também, da efetiva produção do resultado útil programado e da satisfação do interesse do credor $^{135}$. Em outras palavras, o credor não deseja o cumprimento da prestação do devedor em abstrato, mas sim daquela prestação - que nós chamamos aqui de "prestação devida" - que lhe assegura o resultado programado e que satisfaça o interesse concreto do credor.

\title{
Conforme observa João Calvão da Silva:
}

\begin{abstract}
Na medida em que a relação obrigacional está colimada à satisfação do interesse do credor e se dirige justamente à realização de tal interesse, só há cumprimento, em sentido estrito e tecnicamente rigoroso, quando o próprio devedor realiza efetivamente a prestação a que se encontra adstrito e proporciona certo resultado útil ao credor, em conformidade com o programa obrigacional. ${ }^{136}$
\end{abstract}

No mesmo sentido entendem Ramón Daniel Pizarro e Carlos Gustavo Vallespinos:

\footnotetext{
${ }^{133}$ MARTINS-COSTA, Judith. Comentários ao novo Código Civil: do inadimplemento das obrigações. v. V. tomo 2. Rio de Janeiro: Forense. 2003. p. 67.

${ }^{134}$ Por estar a atual noção de adimplemento tão intimamente ligada à perfeição com que se dá o cumprimento de uma obrigação, Antunes Varela afirma que "a regra mais importante a observar no cumprimento da obrigação é a da pontualidade", fazendo a ressalva de que a noção de pontualidade é utilizada por ele "não no sentido restrito de cumprido a tempo e horas, mas no sentido amplo de que o cumprimento deve coincidir, ponto por ponto, em toda a linha, com a prestação a que o devedor se encontra adstrito". VARELA, João de Mattos Antunes. Das obrigações em geral. Coimbra: Almedina. 1970. p. 691.

${ }^{135}$ TERRA, Aline de Miranda Valverde. Inadimplemento anterior ao termo. Rio de Janeiro: Renovar. 2009. p. 83.

136 SILVA, João Calvão da. Cumprimento e sanção pecuniária compulsória. Coimbra: Livraria dos Advogados Editora. 1987. p. 78.
} 
[...] Por eso, junto a una calificada doctrina, entendemos que sólo puede hablarse de cumplimiento en sentido estricto cuando 'el programa obligacional haya tenido realización de idéntica manera, en las rigurosas condiciones y por los mismos sujetos que se tomaron en cuenta a la hora de conformar aquél. ${ }^{137}$

Saliente-se que o cumprimento ou descumprimento da prestação deve ser analisado à luz do fim concreto do contrato, ou seja, do propósito efetivamente perseguido pelas partes com a constituição daquela relação obrigacional específica. Impõe-se, na lição de Pietro Perlingieri, "uma investigação em chave funcional, isto é, que tenha em conta a valoração dos interesses considerados não genericamente", mas que os examine "singularmente e concretamente". ${ }^{138}$ Desta feita, o conceito de adimplemento deverá abarcar a satisfação do fim concreto de cada relação obrigacional.

Examinado o adimplemento sob essa noção complexa e funcional, a doutrina moderna ressalta que houve uma profunda transformação de diversos aspectos do adimplemento, entre os quais o temporal (momento de verificação do adimplemento), o conceitual (condições para verificação do adimplemento) e consequencial (efeitos que decorrem do adimplemento). Em cada um destes aspectos, é possível constatar a presença de novas figuras criadas pela doutrina e jurisprudência, todas vinculadas, direta ou indiretamente, à boa-fé objetiva, como o inadimplemento antecipado, a violação positiva do contrato, o adimplemento substancial e a responsabilidade pós-contratual ${ }^{139}$.

Com relação ao aspecto temporal do adimplemento, vale recordar que a doutrina tradicional entendia que o adimplemento se resumia a um ato pontual do devedor: a entrega da coisa, a restituição do objeto, o pagamento do preço, a realização do ato devido. $\mathrm{O}$ que se passava antes ou depois desse ato pontual era indiferente e irrelevante

137 PIZARRO, Ramón Daniel; VALLESPINOS, Carlos Gustavo. Instituciones de derecho privado. Obligaciones 2. Editorial Hammurabi SRL: Buenos Aires. 1999. p. 74. Em tradução livre: "Por isso, junto à doutrina qualificada, entendemos que somente pode se falar em adimplemento em sentido estrito quando o programa obrigacional tiver se realizado de maneira idêntica, nas rigorosas condições e pelos mesmos sujeitos que levaram em consideração na formação do contrato."

${ }^{138}$ PERLINGIERI, Pietro. Il fenomeno dell'estinzione nelle obbligazioni, Camerino-Napoli. E.S.I. 1980. p. 21.

139 SCHREIBER, Anderson. A tríplice transformação do adimplemento. Adimplemento substancial, inadimplemento antecipado e outras figuras. Revista Trimestral de Direito Civil. Rio de Janeiro, v. 32, out./dez 2007, p. 10. 
para o direito obrigacional ${ }^{140}$. A doutrina ainda hoje afirma que "o sujeito passivo da obrigação só tem de cumpri-la na época do vencimento, de tal modo que "ao credor não é lícito antecipar-se, pedindo a satisfação da dívida antes do vencimento". ${ }^{141}$

Todavia, a doutrina moderna afirma que a releitura funcional e dinâmica da relação obrigacional impõe reconhecer "o encadeamento, em forma processual, dos atos que tendem ao adimplemento do dever" ${ }^{\prime 142}$. Entende-se, assim, que as partes contratantes devem, ao longo da relação contratual, observar todos os atos preparatórios e atos de execução para que a prestação principal possa ser entregue no momento, no local e na forma pactuada no contrato.

A título de exemplo, pode-se mencionar um contrato visando à construção de um edifício. No termo ajustado entre as partes, o empreiteiro deve adimplir a sua prestação entregando ao credor a obra pronta e acabada. Todavia, para que isso seja possível, o empreiteiro deverá observar os atos preparatórios e atos de execução necessários para que a prestação principal possa ser entregue no termo definido pelas partes. Ou seja, meses ou anos antes do termo, a depender do tipo e do porte da edificação, o empreiteiro deverá cumprir a sua obrigação para que a edificação esteja concluída conforme o pactuado. Desta feita, o adimplemento não se perfaz somente com o advento do termo, mas é perpetrado durante toda a relação contratual.

Outrossim, a doutrina moderna ressalta que existem deveres anexos decorrentes da boa-fé - que incidem durante toda a relação contratual, estabelecendo padrões de comportamento às partes desde as negociações até mesmo após a extinção do vínculo, não se restringindo ao momento estático em que a prestação principal deve ser entregue ao credor.

\footnotetext{
140 SCHREIBER, Anderson. A tríplice transformação do adimplemento. Adimplemento substancial, inadimplemento antecipado e outras figuras. Revista Trimestral de Direito Civil. Rio de Janeiro, v. 32, out./dez 2007, p. 10-11.

${ }^{141}$ BEVILAQUA, Clovis. Direito das obrigações. Campinas: Red Livros. 2000. p. 149-151.

${ }^{142}$ SILVA, Clóvis do Couto e. A obrigação como processo. Rio de Janeiro: Editora FGV. 2006. p. 13.
} 
Diante da crescente importância do princípio da boa-fé objetiva, afirma-se que o comportamento das partes antes, durante e depois do cumprimento da prestação principal passa a produzir efeitos jurídicos diferenciados, que podem até ultrapassar, em importância, aqueles que resultam do cumprimento da obrigação em si. ${ }^{143}$ Conforme se abordará no próximo item, parcela da doutrina sustenta que a violação de deveres laterais durante a relação contratual, a depender dos seus efeitos no caso concreto, poderá levar ao inadimplemento contratual.

Observa-se que o adimplemento assume uma perspectiva temporal, consistindo em um processo dinâmico dentro do qual o devedor deve executar uma série de atos e observar inúmeros deveres (principais, secundários e anexos) necessários ao adimplemento no tempo, lugar e forma acordados. O adimplemento não se restringe ao momento em que a prestação deve estar cumprida, mas se desdobra ao longo de toda a vigência da relação obrigacional, de maneira que as partes adotem a conduta para tanto desde a celebração do contrato até após a sua extinção ${ }^{144}$.

Confira-se, abaixo, o posicionamento de Anderson Schreiber acerca do tema:

\begin{abstract}
Com efeito, seja nas obrigações negativas, seja nas positivas, o adimplemento não se limita ao instante singular do seu cumprimento, mas se espraia pela continuidade da relação obrigacional, para atrair em seu favor a conduta das partes antes e depois do vencimento da obrigação. Assim, à luz da boa-fé objetiva, o adimplemento passa a ser compreendido como um processo que se estende temporalmente, abrangendo o comportamento das partes antes e após o momento pontual do vencimento. ${ }^{145}$
\end{abstract}

É por isso que se afirma que deve ser superada a visão estática do direito obrigacional, que posterga para o advento do termo a análise a respeito da possibilidade e da utilidade do adimplemento. Esse exame deverá ser realizado ao longo de todo o desenvolvimento da relação obrigacional, em concomitância com a execução dos atos

\footnotetext{
143 SCHREIBER, Anderson. A tríplice transformação do adimplemento. Adimplemento substancial, inadimplemento antecipado e outras figuras. Revista Trimestral de Direito Civil. Rio de Janeiro, v. 32, out./dez 2007, p. 11.

${ }^{144}$ TERRA, Aline de Miranda Valverde. Inadimplemento anterior ao termo. Rio de Janeiro: Renovar. 2009. p. 85-86.

145 SCHREIBER, Anderson. A tríplice transformação do adimplemento. Adimplemento substancial, inadimplemento antecipado e outras figuras. Revista Trimestral de Direito Civil. Rio de Janeiro, v. 32, out./dez 2007, p. 14.
} 
preparatórios, dos atos propriamente de execução, e dos deveres anexos impostos pela boafé. A todo o momento deve ser verificada a manutenção do interesse típico e concreto do credor na prestação devida e a real possibilidade de adimplemento ${ }^{146}$.

Foi diante da percepção de que direito obrigacional assumiu aspecto dinâmico e de que o adimplemento não se restringe ao momento em que a prestação deve estar cumprida, mas se desdobra ao longo de toda a vigência da relação obrigacional, que a doutrina moderna começou a sustentar que a infringência de deveres de conduta e de deveres anexos ao longo da relação contratual pode configurar - desde que preenchidos certos requisitos - um inadimplemento antecipado do contrato ${ }^{147}$, que autoriza que o credor tome medidas como a resolução do contrato. É a esse tema que se dedicarão os próximos dois capítulos da presente dissertação.

Por fim, acrescente-se que, se a incidência de deveres de conduta na relação obrigacional importa, por um lado, a ampliação do conceito de adimplemento, por outro conduz à limitação do exercício do direito do credor à resolução do contrato por descumprimento meramente formal da prestação devida. Vale dizer:

Da mesma forma que o cumprimento meramente estrutural da prestação principal não configura adimplemento, exigindo a análise mais atenta à função concreta da relação obrigacional, a inadequação formal do comportamento do devedor ao débito, tal como estruturalmente definido pelas partes, não ensejará inadimplemento, desde que atendido o escopo especificamente perseguido pelas partes com a constituição do vínculo obrigacional. ${ }^{148}$

\footnotetext{
146 Nesse sentido se posiciona Pietro Perlingieri: "l'interesse creditorio deve permanere per tutto l'arco temporale di durata del rapporto obbligatorio, sino alla sua estionzione (che, fisiologicamente, consegue all'esatto adempimento, quale vicenda estintiva satisfattoria per eccellenza).” PERLINGIERI. Manuale di diritto civile. Napoli: ESI, 1997, p. 218. Em tradução livre: "o interesse do credor deve permanecer durante todo o tempo de duração da relação obrigacional, até sua extinção (que, fisiologicamente, é consequência do exato cumprimento, como fato que por si próprio extingue satisfazendo)."

${ }^{147}$ De acordo com Jorge Cesa Ferreira da Silva, o inadimplemento antecipado do contrato pode decorrer tanto da infringência de deveres principais como secundários de prestação, como ainda dos deveres laterais, anexos ou instrumentais de conduta, configurando, nesta última hipótese, a violação positiva do contrato. SILVA, Jorge Cesa Ferreira da. A boa-fé e a violação positiva do contrato. Rio de Janeiro: Renovar. 2002. p. 261.

148 SCHREIBER, Anderson. A tríplice transformação do adimplemento. Adimplemento substancial, inadimplemento antecipado e outras figuras. Revista Trimestral de Direito Civil. Rio de Janeiro, v. 32, out./dez 2007, p. 17-18.
} 
Trata-se da figura do adimplemento substancial. O adimplemento substancial examina se, no caso concreto, a obrigação foi cumprida em seus pontos relevantes, importantes, essenciais ${ }^{149}$. O adimplemento substancial não permite, por exemplo, a resolução do vínculo contratual se houver cumprimento significativo, expressivo das obrigações assumidas ${ }^{150}$. Nas palavras de Clóvis do Couto e Silva é "um adimplemento tão próximo do resultado final, que, tendo-se em vista a conduta das partes, exclui-se o direito de resolução, permitindo tão somente o pedido de indenização."

Inspirada na substantial performance do direito anglo-saxônico, a construção do adimplemento substancial surge com o objetivo de autorizar "a avaliação de gravidade do inadimplemento antes de deflagrar a consequência drástica consubstanciada na resolução da relação obrigacional". ${ }^{152}$ Nesse sentido, a teoria avalia a gravidade do descumprimento, de modo a limitar o exercício da resolução contratual sempre que, de um lado, houver um incumprimento insignificante das obrigações assumidas e, de outro lado, o descumprimento de uma prestação não alterar o sinalagma do contrato, a sua finalidade econômico-social, o interesse do credor e o resultado útil programado ${ }^{153}$.

149 BUSSATA, Eduardo Luiz. Resolução dos contratos e teoria do adimplemento substancial. São Paulo: Saraiva. 2007. p. 37.

${ }^{150}$ Vale mencionar que o Código Civil italiano estabelece que o inadimplemento deva ter efetiva importância para possibilitar que o contrato seja resolvido. Se a importância do inadimplemento for pequena (scarsa, na letra daquela lei), o contrato não poderá ser resolvido. Confira-se a redação do mencionado dispositivo legal: “Art. 1.455. Importanza dell'inadempimento. Il contratatto non si può risolvere se l'inadempimento di una delle parti ha scarsa importanza, avuto riguardo all'interesse dell'atra." Em tradução livre: "Importância do inadimplemento. $\mathrm{O}$ contrato não pode ser resolvido se o inadimplemento de uma das partes é de menor importância, resguardado o interesse da outra."

151 BECKER, Anelise. A doutrina do adimplemento substancial no direito brasileiro e em perspectiva comparativista. Revista da Faculdade de Direito UFRGS, v. 9, Porto Alegre, Universidade Federal do Rio Grande do Sul, nov. 1993, p. 60.

${ }^{152}$ SCHREIBER, Anderson. A boa-fé objetiva e o adimplemento substancial. In: HIRONAKA, Giselda Maria Fernandes Novaes; TARTUCE, Flávio (Coord.). Direito Contratual. Temas Atuais. São Paulo: Método. 2007. p. 138.

${ }^{153}$ A esse respeito, é importante conferir as considerações de Jones Figueirêdo Alves: “Com efeito, o suporte fático que orienta a doutrina do adimplemento substancial, como fator desconstrutivo do direito da resolução do contrato por inexecução contratual, é o incumprimento insignificante. Isso quer dizer que a hipótese da resolução contratual por inadimplemento haverá de ceder diante do pressuposto do atendimento quase integral das obrigações pactuadas, em posição contratual na qual se coloca o devedor, não se afigurando razoável a extinção do contrato. Não haverá inadimplemento imputável para resolver o contrato, quando o adimplemento parcial reflita, com seu alcance, a pauta da avença, na proporção veemente das obrigações concretizadas." ALVES, Jones Figueirêdo. A teoria do adimplemento substancial ("substancial performance") do negócio jurídico como elemento impediente ao direito de resolução do contrato. In: DELGADO, Mário Luiz; ALVES, Jones Figueirêdo (Coord.). Questões controvertidas no direito das obrigações e dos contratos. Série Grandes Temas de Direito Privado. v. 4. Editora Método: São Paulo. 2005. p. 406. 
Entende-se que, quando um incumprimento insignificante não abalar o sinalagma contratual, o desfazimento da relação contratual importará em sacrifício injusto e desproporcional para o devedor, em comparação com a manutenção do contrato. A boafé objetiva funciona como limite ao exercício abusivo de posição jurídica e impõe a adoção de outros meios de tutela diante do cumprimento imperfeito, mas significativo, das obrigações. O adimplemento substancial surgiu, assim, para "frear o rigor do direito à extinção contratual e despertar a comunidade jurídica para o exercício quase malicioso de um direito de resolução em situação que só formalmente não se qualificava como adimplemento integral" $" 154$.

Atualmente, conforma destaca Anderson Schreiber, a importância do adimplemento substancial está não apenas em impedir a resolução do contrato diante de cumprimento apenas formalmente imperfeito, mas em permitir o controle judicial da legitimidade dos diversos mecanismos de tutela do credor, inclusive, e, sobretudo, diante de outras hipóteses de inadimplemento do devedor ${ }^{155}$. O adimplemento substancial é, como será discutido adiante, um dos limites de aplicação da teoria do inadimplemento antecipado dos contratos.

Nota-se, portanto, a partir de uma perspectiva funcional e dinâmica, que o adimplemento sofreu uma dúplice transformação. No que diz respeito ao seu conceito, o adimplemento passou a ser entendido como o cumprimento da prestação devida, observados os deveres anexos impostos pela boa-fé objetiva e o fim concreto do contrato. No que tange ao aspecto temporal, se contata a insuficiência de uma análise estática de adimplemento, eis que ele se projeta no tempo, e impõe a observância de deveres de conduta e deveres anexos desde a celebração do contrato até mesmo após a sua extinção. É sob essa perspectiva que o conceito de inadimplemento deverá ser analisado.

${ }^{154}$ SCHREIBER, Anderson. A boa-fé objetiva e o adimplemento substancial. In: HIRONAKA, Giselda Maria Fernandes Novaes; TARTUCE, Flávio (Coord.). Direito contratual. Temas Atuais. São Paulo: Método. 2007. p. 141.

155 SCHREIBER, Anderson. A tríplice transformação do adimplemento. Adimplemento substancial, inadimplemento antecipado e outras figuras. Revista Trimestral de Direito Civil. Rio de Janeiro, v. 32, out./dez 2007, p. 21-23. 


\title{
1.7. O papel do credor na relação obrigacional e a sua importância para o adimplemento - os efeitos do inadimplemento do credor
}

É importante destacar que todas as transformações que a boa-fé objetiva promoveu no campo do direito das obrigações também alteraram profundamente o papel (e o que se espera) do credor na relação obrigacional. À luz dos deveres anexos decorrentes da boa-fé objetiva, não é mais possível se cogitar de um credor que seja mero "espectador" e que simplesmente aguarde o termo contratual para demandar o cumprimento forçado da prestação em caso de inadimplemento.

Atualmente, cada vez mais se exige uma postura colaborativa e cooperativa do credor ao longo do iter obrigacional. A noção da obrigação como processo exige a cooperação do alter (outro), seja ele credor, seja devedor ou terceiro, para viabilizar o cumprimento do programa obrigacional ${ }^{156}$, consoante observa Pietro Perlingieri:

\begin{abstract}
A obrigação não se identifica com o direito ou com os direitos do credor; ela se configura cada vez mais como uma relação de cooperação. Isto implica uma mudança radical da perspectiva a partir da qual enfocar a disciplina das obrigações: esta não deve ser considerada o estatuto do credor; a cooperação substitui a subordinação e o credor se torna titular de deveres genéricos ou específicos de cooperação para o adimplemento pelo devedor. Também o terceiro se encontra envolvido neste novo clima de colaboração e de responsabilidade, em que o crédito assume cada vez mais a fisionomia de um 'bem' autônomo, sobre o qual manifestamente incidem direitos de terceiros qualificados [...] e que os terceiros devem respeitar. ${ }^{157}$
\end{abstract}

\footnotetext{
156 Paulo Lôbo destaca que "tradicionalmente, a obrigação, especialmente o contrato, foi considerada composição de interesses antagônicos, do credor de um lado, do devedor de outro. Por exemplo, o interesse do comprador seria antagônico ao do vendedor. Tal esquema era adequado ao individualismo liberal, mas é inteiramente inapropriado à realização do princípio constitucional da solidariedade, sob o qual a obrigação é tomada como um todo dinâmico, processual, e não apenas como estrutura relacional de interesses individuais. $\mathrm{O}$ antagonismo foi substituído pela cooperação, tido como dever de ambos os participantes e que se impõe aos terceiros. Revela-se a importância não apenas da abstenção de condutas impeditivas ou inibitórias, mas das condutas positivas que facilitem a prestação do devedor". LÔBO, Paulo. Direito civil: obrigações. 3. ed. São Paulo: Saraiva, 2013. p. 95.

${ }^{157}$ PERLINGIERI, PIETRO. O direito civil na legalidade constitucional. Trad. de Maria Cristina De Cicco. Rio de Janeiro: Renovar. 2008. p. 912-913. No mesmo sentido, Thiago Luís Santos Sombra afirma que "uma das marcas mais claras da associação do comportamento cooperativo aos deveres laterais ou de conduta decorre dos atributos de alteridade e confiança, ou seja, da imposição indistinta de posturas ao credor e ao devedor, a partir da legítima expectativa despertada”. SOMBRA, Thiago Luís Santos. Adimplemento contratual e colaboração do credor. São Paulo: Saraiva. 2011. p. 143-144.
} 
Conforme observa Giovanni Ettore Nanni, “a simples imposição do dever de prestação ao devedor em decorrência do vínculo obrigacional não se demonstrava suficiente para possibilitar o efetivo cumprimento do negócio", sendo necessária uma postura cooperativa do credor, para que não fossem "criados obstáculos para o adimplemento da obrigação" 158 .

Com efeito, não há plena satisfação de interesses ou perfeito adimplemento que possa ser alcançado sem a respectiva cooperação das partes contratantes ${ }^{159}$. Daí porque o credor - e não somente o devedor - também deverá observar o dever de colaboração decorrente da boa-fé objetiva para que o devedor possa cumprir a prestação devida, e por consequência, a obrigação reste adimplida e sejam satisfeitos os interesses das partes naquela relação específica ${ }^{160}$.

Nas precisas palavras de Clóvis V. do Couto e Silva:

A concepção atual da relação jurídica, em virtude da incidência do princípio da boa-fé, é a de uma ordem de cooperação, em que se aluem as posições tradicionais do devedor e credor. Com isso, não se pense que o credor deixará de estar nitidamente desenhado como aquele partícipe da relação jurídica que é

\footnotetext{
158 NANNI, Giovanni Ettore. O dever de cooperação nas relações obrigacionais à luz do princípio constitucional da solidariedade. In: NANNI, Giovanni Ettore (Coord.) Temas relevantes do direito civil contemporâneo: reflexões sobre os cinco anos do Código Civil. São Paulo: Atlas. 2008. p. 308.

159 Não obstante o caráter colaborativo da relação obrigacional, em que ambas as partes devem conjugar esforços rumo ao adimplemento contratual, não se pode negar o pressuposto de que a relação obrigacional visa principalmente satisfazer os interesses do credor. Com efeito, os interesses do credor representam o pilar do vínculo obrigacional e definem a função da obrigação, o que denota a sua prevalência sobre os interesses do devedor. No entanto, embora tenham um peso menor, os interesses do devedor também devem ser prestigiados, notadamente no que tange à necessária colaboração do credor para permitir o adimplemento contratual e à sua liberação da relação. Neste sentido: “[...] impede asseverar que, embora subalternizados, os interesses do devedor recebem o influxo, ou melhor, a contribuição dos deveres de conduta também impostos ao credor, notadamente no que se refere à sua liberação da relação jurídica, sem encargos despropositados". SOMBRA, Thiago Luís Santos. Adimplemento contratual e colaboração do credor. São Paulo: Saraiva. 2011. p. 27-28.

${ }^{160}$ Antonio Menezes Cordeiro afirma que: "numa leitura atomística, o devedor estaria adstrito à prestação tendo o credor, apenas, um direito à mesma. Na prática, verifica-se que, em regra, as obrigações são sinalagmáticas: ambas as partes surgem, em simultâneo, como credoras e devedoras uma da outra. [...] Vamos, porém, mais longe: mesmo o credor 'puro' tem alguns deveres a seu cargo. Desde logo, ele poderá ter de colaborar para que a prestação principal seja possível: o cliente do barbeiro tem de comparecer no local próprio e, aí, terá de assumir a postura física que permita a realização da prestação a que tem direito. $\mathrm{O}$ credor que não faculte a execução da prestação entra em mora $\left(813^{\circ}\right.$ e ss.) e sujeita-se a determinadas consequências. Adiante veremos se se trata de (meros) encargos ou de deveres: há, de todo o modo e aqui, um elemento passivo que integra a posição". CORDEIRO, Menezes António. Tratado de direito civil português II. Direito das obrigações. tomo I. Coimbra: Almedina. 2009. p. 301.
} 
titular de direitos e pretensões. Amenizou-se, é certo, a posição deste último, cometendo-se-lhe, também, deveres, em virtude da ordem de cooperação. Com isso, ele não deixou de ser o credor, sujeito ativo da relação, mas reconheceu-se que a ele cabiam certos deveres. Não caberá, a toda evidência, a efetivação da obrigação principal, porque isso é pensão precípua do devedor. Caber-lhe-ão, contudo, certos deveres como os de indicação e de impedir que a sua conduta venha dificultar a prestação do devedor. ${ }^{161}$

Ressalte-se, todavia, que essa questão é controversa na doutrina. João Calvão, por exemplo, entende que o ato de cooperação do credor no cumprimento "não é normalmente um dever jurídico, mas apenas um ônus jurídico a que não se contrapõe um direito subjetivo do devedor". Segundo o referido doutrinador, o credor não tem o dever de cooperar, "já que o escopo típico da obrigação é o de proporcionar um resultado útil ao credor através da prestação do devedor" ${ }^{\prime 162}$.

No entanto, se analisada a relação obrigacional em seu aspecto dinâmico e finalístico, concordar que a cooperação é um mero ônus do credor e que a sua ausência implica apenas consequências ao credor no que toca os riscos da mora, parece-nos um pouco simplista demais. À luz do princípio da boa-fé objetiva, entendemos que é mais adequado falar em dever de cooperação do credor do que em um simples ônus jurídico.

Com efeito, o padrão de comportamento leal e probo imposto pela boa-fé impõe ao credor o dever de evitar que a prestação (ou a indenização, em caso de inadimplemento) se torne excessivamente mais onerosa, assim como o dever de proporcionar ao devedor a cooperação de que ele razoavelmente necessite para realizar a prestação devida ${ }^{163}$. Há um dever de cooperação do credor que, se descumprido, acarretará consequências, conforme se analisará adiante.

${ }^{161}$ SILVA, Clóvis do Couto e. A obrigação como processo. Rio de Janeiro: Editora FGV. 2006. p. 97.

162 SILVA, João Calvão da. Cumprimento e sanção pecuniária compulsória. Coimbra: Livraria dos Advogados Editora. 1987. p. 117-118. Jorge Cesa Ferreira da Silva, ao comentar a regra do artigo 400 do Código Civil, sustenta que o dever de colaborar em algumas situações "se traduz em ônus jurídico", de modo que "o fato de a colaboração do credor não se concretizar em um dever em sentido estrito justifica o regime da mora creditoris". SILVA, Jorge Cesa Ferreira da. Inadimplemento das obrigações. São Paulo: Revista dos Tribunais. 2007. p. 118-119.

${ }^{163}$ A esse respeito, Antunes Varela exemplifica como deveres anexos do credor "os deveres destinados a evitar que a prestação se torne desnecessariamente mais onerosa ou a proporcionar ao dever as condições de que ele razoavelmente necessita para realizar a prestação devida". VARELA, João de Mattos Antunes. Das obrigações em geral. Coimbra: Almedina. 1970, p. 86 
Esclareça-se que esse dever de cooperação do credor não se resume aos deveres laterais, devendo estar presente também no cumprimento dos deveres principais e secundários da prestação ${ }^{164}$, bem como que o dever de colaboração abrange não somente a abstenção da prática de atos que impeçam o adimplemento, mas também uma postura ativa que contribua efetivamente para o adimplemento pelo devedor ${ }^{165}$.

São exemplos de deveres de colaboração: o contratante permitir que o pintor contratado ingresse em sua residência para que ele consiga prestar o serviço; o segurado informar rapidamente para a seguradora sobre o sinistro e tentar minorar as suas consequências; o contratante obter as licenças e autorizações necessárias para que o empreiteiro possa iniciar as obras; o locatário impedir danos na coisa locada, etc.

Segundo Giovanni Ettore Nanni "é imperioso que as partes busquem, na proporção dos esforços que lhes cabem, em cooperação, o adimplemento da obrigação assumida" e "é este o espírito que norteia a relação obrigacional no atual cenário constitucional-civilístico: a atuação das partes em cooperação para atingir a satisfação da obrigação"166.

Este também é o posicionamento de Fernando Noronha:

[...] Numa relação obrigacional complexa considera-se o conjunto de direitos e deveres que unem as partes intervenientes, em razão das quais elas são adstritas a cooperarem, para a realização dos interesses de que sejam credoras, mas com o

\footnotetext{
164 NANNI, Giovanni Ettore. O dever de cooperação nas relações obrigacionais à luz do princípio constitucional da solidariedade. In: NANNI, Giovanni Ettore (Coord.). Temas relevantes do direito civil contemporâneo: reflexões sobre os cinco anos do Código Civil. São Paulo: Atlas. 2008. p. 316.

${ }^{165}$ Consoante esclarece Cláudia Lima Marques: "Este dever de cooperar deve também ser cumprido de forma ativa pelo fornecedor; assim, se o fornecedor está obrigado a cumprir com suas obrigações (por exemplo: reembolsar ou fornecer determinados exames e consultas médicas, entregar determinado bem, executar determinado serviço) não deve dificultar o acesso do consumidor aos seus direitos ou inviabilizar que a prestação seja devida. Deve o fornecedor, igualmente, abster-se de usar ou impor expedientes desnecessários ou maliciosos, como exigir uma grande série de autorizações, documentos, solicitações só retiráveis em determinados locais, em determinada hora e por decisão arbitrária do próprio fornecedor, exigir comunicações imediatas ou em curto espaço de tempo em matérias que envolvem a integridade física, psíquica da pessoa e seus familiares, e ainda mais, exigindo esta atuação contratual sob pena de perda dos direitos contratuais." MARQUES, Cláudia Lima. Contratos no Código de Defesa do Consumidor: o novo regime das relações contratuais. São Paulo: Ed. Revista dos Tribunais. 3. ed., $2^{a}$ tiragem. p. 197.

166 NANNI, Giovanni Ettore. O dever de cooperação nas relações obrigacionais à luz do princípio constitucional da solidariedade. In: NANNI, Giovanni Ettore (Coord.). Temas relevantes do direito civil contemporâneo: reflexões sobre os cinco anos do Código Civil. São Paulo: Atlas. 2008. p. 318.
} 
devido respeito pelos recíprocos interesses do devedor, ou devedores, e tendo em conta também a função social desempenhada, que é a razão última de sua tutela."167

A relação obrigacional abrange, assim, uma "totalidade" de direitos e deveres, incluindo os deveres anexos e especialmente o dever de cooperação, em que não há uma oposição entre os interesses das partes ou mesmo uma hierarquia entre o credor e o devedor. Ao invés da predominância da ideia de confronto, a boa-fé e os deveres anexos impõem que o contrato deve passar a ser visualizado como um "projeto comum" entre credor e devedor com o propósito de satisfazer os seus interesses, em que, para atingir tal fim, as partes devem colaborar ${ }^{168}$. Ambas as partes devem atuar de maneira colaborativa com o objetivo de alcançar o adimplemento e satisfazer o programa obrigacional ${ }^{169}$.

Nesse sentido, sustenta Judith Martins-Costa que:

\begin{abstract}
A colaboração possibilita o adimplemento porque, para que seja eficazmente atingido, é necessário que as partes atuem, ambas, em vista do interesse legítimo do alter. As partes de uma relação obrigacional não são entidades isoladas e estranhas, atomisticamente consideradas; pelo contrário, tendo se aproximado em virtude de contrato social juridicamente qualificado por graus de proximidade ou distância (e o grau que aproxima dois contratantes é de extrema proximidade), as partes estão entre si relacionadas, razão pela qual a necessidade de colaboração intersubjetiva constitui, como afirmou Menezes Cordeiro, "princípio geral da disciplina obrigacional". 170
\end{abstract}

Em que pese não existir previsão expressa do dever de colaboração das partes no Código Civil de 2002, entendemos que ele pode ser perfeitamente invocado no direito brasileiro com base na função integrativa da boa-fé objetiva, que impõe um novo standard

\footnotetext{
${ }^{167}$ NORONHA, Fernando, Direito das obrigações. v. I. São Paulo: Saraiva, 2013. p. 92. No mesmo sentido, Claudio Luiz Bueno de Godoy afirma que "[...] a boa-fé faz do ajuste, hoje, muito mais uma relação de cooperação, de consideração com o outro, destarte garantindo a promoção do solidarismo que, como visto, é valor constitucional e, nesta senda, imbricando-se com a função social do contrato". GODOY, Claudio Luiz Bueno de. Função social do contrato: os novos paradigmas contratuais. São Paulo: Saraiva. 2004. p. 75.

168 NANNI, Giovanni Ettore. O dever de cooperação nas relações obrigacionais à luz do princípio constitucional da solidariedade. In: NANNI, Giovanni Ettore (Coord.). Temas relevantes do direito civil contemporâneo: reflexões sobre os cinco anos do Código Civil. São Paulo: Atlas. 2008. p. 318.

${ }^{169}$ Paulo Lôbo salienta que "o dever de colaboração resulta em questionamento da estrutura da obrigação, uma vez que, sem alterar a relação de crédito e débito, impõe prestações ao credor enquanto tal. Assim, há dever de cooperação tanto do credor quanto do devedor, para o fim comum". LÔBO, Paulo. Direito civil: obrigações. 3. ed. São Paulo: Saraiva. 2013. p. 99.

${ }^{170}$ MARTINS-COSTA, Judith. Comentários ao novo Código Civil. Rio de Janeiro: Forense. 2004. p. 26.
} 
de comportamento leal e probo para as partes contratantes, que abrange uma postura cooperativa rumo ao adimplemento contratual ${ }^{171}$.

A jurisprudência brasileira já começou a reconhecer que a boa-fé objetiva impõe a ambas as partes deveres anexos dotados de "imperatividade", dentre os quais, o dever de colaboração, que se traduz "em obrigação das partes contratantes, que devem agir sempre no sentido de não impedir o efetivo cumprimento das obrigações contratuais" ${ }^{172}$.

Acrescente-se que o dever de cooperação é previsto dentre os Princípios Unidroit aplicáveis aos Contratos Comerciais Internacionais de 2004, em que se estabelece no artigo 5.1.3: "Cada parte deve cooperar com a outra quando tal cooperação pode ser razoavelmente esperada para o cumprimento das próprias obrigações". Os Princípios Fundamentais do Direito Europeu dos Contratos, publicados pela European Contract Law Commission, também dispõem no artigo 1:202: "Obrigação de cooperação. As partes são obrigadas reciprocamente a cooperar com a finalidade de dar plena execução ao contrato.” Tais previsões evidenciam que a tendência no direito internacional é conferir cada vez mais importância ao dever de cooperação.

Por fim, destacamos que o dever de colaboração é dotado de exigibilidade jurídica, haja vista que ele serve para que a relação obrigacional "tenha um limite no tempo, com a satisfação do interesse do credor, outorgando-se ao devedor os meios [...] para obter a sua liberação". ${ }^{173}$ Em outras palavras, o dever de colaboração é exigível na medida em que a cooperação do credor é essencial para que o devedor possa cumprir a

\footnotetext{
${ }^{171}$ A esse respeito, Thiago Luís Santos Sombra afirma que "a perspectiva da evolução axiológica do dever de cooperação se consumou a partir do momento em que se abalaram as posições tradicionalmente ocupadas por credor e devedor. Como dito, à boa-fé objetiva se deve sobremaneira essa mudança de paradigma. Com ela agregam-se novos padrões de conduta à relação obrigacional, notadamente porque o comportamento de ambos os sujeitos mereceu relevo, a par da primazia inevitavelmente conferida ao credor. Isso demonstra claramente um redirecionamento das relações obrigacionais, a evidenciar que também ao credor são impostas certas condutas [...]" SOMBRA, Thiago Luís Santos. Adimplemento contratual e colaboração do credor. São Paulo: Saraiva. 2011. p. 142.

${ }^{172}$ Neste sentido: STJ, REsp 595631, Rel. Ministra Nancy Andrighi, j. 08.06.2004.

173 NANNI, Giovanni Ettore. O dever de cooperação nas relações obrigacionais à luz do princípio constitucional da solidariedade. In: NANNI, Giovanni Ettore (Coord.). Temas relevantes do direito civil contemporâneo: reflexões sobre os cinco anos do Código Civil. São Paulo: Atlas. 2008. p. 302.
} 
prestação devida e se liberar do vínculo obrigacional, tendo a sua liberdade restituída ${ }^{174}$.

Nas palavras de Anteo E. Ramella:

[...] si bien es cierto que el deudor tiene el deber de cumplir, también tiene el derecho a liberación. No es posible admitir que el deudor deba quedar necesariamente atado a sus obligaciones por la sola voluntad del acreedor. Así como el retardo en el cumplimiento de la prestación puede traer aparejados perjuicios para el acreedor, también los puede traer para el propio deudor, quien en el desarrollo de sus negocios o actividad profesional habrá hecho sus cálculos y programado el cumplimiento de sus diversas obligaciones en tiempo oportuno. ${ }^{175}$

Vale salientar que o dever de cooperação não "pode ser tão largamente reclamando a ponto de deixar de ser um racional ato de colaboração solidária obrigacional entre as partes para se transformar em um ato de altruísmo, além das raias cujo comportamento o direito impõe" ${ }^{, 176}$. Esse parece ser, sem sombra de dúvidas, o grande problema que se apresenta: o limite da cooperação demandada do credor e a caracterização da mora accipiendi ${ }^{177}$.

Lilian C. San Martín Neira entende que o credor se exonera de sua obrigação de cooperar quando esta obrigação lhe impuser um "apreciable sacrificio", em casos em que a

\footnotetext{
${ }^{174}$ Conforme o pensamento de Renan Lotufo, "No estudo das obrigações não se vê exclusivamente a figura proeminente do credor, posto que se está diante de uma relação jurídica entre dois sujeitos de igual valor. Assim, não se pode admitir a visão de prisão pelo vínculo, mas a idéia de que a liberdade do devedor é que é o fundamento, como já antevisto por Carnelutti, pois a liberdade é que ficou afetada pela relação obrigacional nascida, relação que, com o adimplemento pelo devedor, vai ser dissolvida, e a plenitude da liberdade juridicamente garantida restabelecida para que a conquistou por sua própria atividade". LOTUFO, Renan. Código civil comentado: obrigações: parte geral (arts. 233 a 420). São Paulo: Saraiva. 2003. v. 2. p. 9.

175 RAMELLA, Anteo E. La Resolución por Incumplimiento. Buenos Aires: Editoral Astrea. 1975. p. 67. Em tradução livre: "Embora seja verdade que o devedor tem o dever de cumprir, também tem o direito de se liberar. Não é possível admitir que o devedor deve ficar vinculado às suas obrigações somente pela vontade do credor. Assim como o atraso no cumprimento da prestação pode trazer prejuízos para o credor, também pode trazê-los para o próprio devedor, que no desenvolvimento de seu negócio ou atividade profissional terá feito seus cálculos e programado o cumprimento das suas obrigações no tempo oportuno."

176 NANNI, Giovanni Ettore. O dever de cooperação nas relações obrigacionais à luz do princípio constitucional da solidariedade. In: NANNI, Giovanni Ettore (Coord.). Temas relevantes do direito civil contemporâneo: reflexões sobre os cinco anos do Código Civil. São Paulo: Atlas. 2008. p. 311.

${ }^{177}$ Segundo observa Thiago Luís Santos Sombra, “ainda hoje vige significativa controvérsia doutrinária em torno da profundidade da cooperação imposta ao credor. Conquanto delicado, é possível adiantar, no entanto, que prepondera perante os italianos a perspectiva da cooperação como ônus, sem o surgimento de um contraposto direito a adimplir; ao passo que para os portugueses, os quais trabalharam com maior acuidade o tema a boa-fé objetiva ao longo dos anos, vigora a ideia de cooperação como dever lateral ou de conduta. Infelizmente, a doutrina e a jurisprudência brasileiras são incipientes sobre o tema, embora existam ensaios e trabalhos altamente técnicos, profundos e específicos" SOMBRA, Thiago Luís Santos. Adimplemento contratual e colaboração do credor. São Paulo: Saraiva. 2011. p. 120-121.
} 
cooperação teria um resultado muito oneroso para o credor $^{178}$. Concordamos com tal limitação, que é inclusive a que melhor se encaixa nas próprias constrições do dever lateral derivado da boa-fé objetiva. A boa-fé objetiva, que cria à parte um dever de conduta, jamais poderia se compatibilizar com deveres que fogem à razoabilidade ou impõem ao credor do dever uma conduta incompatível com a posição que dele normalmente se espera, com base naquele contrato específico e nos usos e costumes. Evidente, portanto, que os deveres anexos não podem significar ao devedor a realização de providências muito onerosas ou desproporcionais.

A nosso ver, a exigibilidade do dever de colaboração pelo credor deverá ser constatada à luz das características concretas de uma determinada relação obrigacional, na qual se deverá avaliar, objetivamente, conforme a boa-fé, qual é a conduta cooperativa legitimamente esperada da parte naquele caso. Somente após fazer essa análise é que se poderá verificar se houve e quais foram os efeitos da violação ao dever de cooperação pelo credor.

Nos próximos itens será feita uma breve análise dos efeitos da violação desse dever de cooperação pelo credor, tema ainda pouco discutido na doutrina brasileira.

\section{8. $O$ inadimplemento contratual}

\subsubsection{A noção de inadimplemento}

O artigo 389 do Código Civil ${ }^{179}$ (assim como o artigo 1.056 do Código Civil de $1916^{180}$ ) trata do inadimplemento por seus efeitos, não cuidando de descrevê-lo ou conceituá-lo. A doutrina tradicionalmente conceituou inadimplemento como "o oposto de

\footnotetext{
178 NEIRA, Lilian C. San Martín. Sobre la naturaleza jurídica de la 'cooperación' del acreedor al cumplimiento de la obligación. La posición dinámica del acreedor en la relación obligatoria, como sujeto no sólo de derechos, sino también de cargas y deberes. Revista de Derecho Privado, ${ }^{\circ}$ 21, p. 208-282, JulioDiciembre, 2011. Disponível em: 〈http://ssrn.com/abstract=1964700. p. 289.L〉. Acesso em: 10 nov. 2014. 179 “Art. 389. Não cumprida a obrigação, responde o devedor por perdas e danos, mais juros e correção monetária segundo índices oficiais regularmente estabelecidos, e honorários de advogado.”

180 “Art. 1.056. Não cumprindo a obrigação, ou deixando de cumpri-la pelo modo e no tempo devidos, responde o devedor por perdas e danos."
} 
adimplemento", para "significar o não cumprimento daquilo a que se está obrigado, dentro do prazo convencionado". ${ }^{181}$ O gênero inadimplemento foi definido como "o não cumprimento da obrigação, nos devidos tempo, lugar e forma" ${ }^{\prime 182}$.

Nesse sentido, Almeida Costa afirma que "verifica-se o não cumprimento, incumprimento ou inadimplemento de uma obrigação sempre que a respectiva prestação debitória deixar de ser efectuada nos termos adequados". No entanto, o próprio autor adverte que "este conceito representa, todavia, um simples ponto de partida, visto que na sua moldura genérica se incluem várias situações com efeitos jurídicos muito diversos" ${ }^{\text {"183 }}$.

Em linhas gerais, inadimplemento indica o não cumprimento, (a) pelo devedor, das normas que impõem a obrigação de prestar ao credor no tempo, lugar e forma que a lei ou contrato estabelecer; e (b) pelo credor, das normas que impõem o recebimento da prestação, também no tempo, lugar e forma que a lei ou o contrato estabelecer. ${ }^{184} \mathrm{O}$ conceito de inadimplemento está, portanto, sempre associado ao não cumprimento de obrigações.

Neste ponto, cumpre observar que a noção de inadimplemento não poderia permanecer inalterada diante das alterações sofridas no direito das obrigações. Se adimplemento e inadimplemento se conectam logicamente e funcionalmente, é inevitável, diante das ponderações anteriores, reler a disciplina do inadimplemento à luz da nova concepção total, dinâmica e funcional do direito das obrigações.

Como discutido nos itens anteriores, o foco da concepção tradicional de adimplemento se volta para o cumprimento da prestação principal. A contrario sensu, o inadimplemento é normalmente conceituado como a inexecução da obrigação principal, a "significar pura e simplesmente que a prestação não é realizada tal como era devida" "185. As noções de adimplemento e de inadimplemento tradicionalmente estão associadas à análise

\footnotetext{
${ }^{181}$ SILVA, De Plácido e. Vocabulário Jurídico. 26. ed. Rio de Janeiro: Editora Forense. 2005. p. 719. ${ }^{182}$ LÔBO, Paulo. Direito civil: obrigações. 3. ed. São Paulo: Saraiva. 2013. p. 231.

${ }^{183}$ ALMEIDA COSTA, Mário Júlio de. Noções de direito civil. Coimbra: Livraria Almedina. 1980. p. 219. ${ }^{184}$ MARTINS-COSTA, Judith. Comentários ao novo Código Civil. Rio de Janeiro: Forense. 2004. p. 82. 185 TELLES, Inocêncio Galvão. Direito das obrigações. Coimbra: Coimbra Editora. 1983. p. 260.
} 
do cumprimento ou descumprimento da prestação principal nos termos em que foi pactuada entre as partes ${ }^{186}$.

Todavia, a ampliação do conceito de adimplemento, diante dos deveres de conduta impostos ao devedor, implica, na mesma medida, no alargamento da noção de inadimplemento. Assim, se para o devedor ser considerado adimplente se impõe a observância não apenas do dever principal de prestação, mas também dos deveres anexos decorrentes da boa-fé, isso significa dizer que se considera inadimplente o devedor que não cumpre o dever principal de prestação, os deveres secundários ou os deveres de conduta impostos pela sistemática obrigacional.

Confiram-se, abaixo, os comentários de Jorge Cesa Ferreira da Silva acerca do tema:

\begin{abstract}
A obrigação abrange, pois, deveres de prestação e de conduta - os chamados deveres laterais - e interesses do credor e do devedor (cf. Jorge Cesa Ferreira da Silva, op. Cit., p. 75 ss.). E se é verdadeiro que se tem por adimplida a obrigação que concretiza os interesses legítimos (ativos e passivos) nela envolvidos e dela decorrentes, não menos certo é que por inadimplemento se deve entender o nãocumprimento ou inobservância por uma das partes de qualquer dever emanado do vínculo obrigacional. $\mathrm{O}$ inadimplemento, assim, não se limita à prestação $\mathrm{e}$ nem aos deveres exclusivamente a ela relacionados. ${ }^{187}$
\end{abstract}

Com efeito, ao se considerarem os deveres laterais decorrentes do princípio da boa-fé objetiva como integrantes da relação jurídica e do objeto da obrigação, ampliou-se o próprio conceito de inadimplemento, que poderá ser ocasionado não só pela quebra dos deveres de prestação, mas também pela violação dos deveres laterais antes, durante e depois da celebração do negócio jurídico. Em sentido amplo, portanto, inadimplemento significa a não realização da prestação devida, com a consequente insatisfação do credor, e não o mero descumprimento da prestação principal ${ }^{188}$.

\footnotetext{
186 SCHREIBER, Anderson. A tríplice transformação do adimplemento. Adimplemento substancial, inadimplemento antecipado e outras figuras. Revista Trimestral de Direito Civil. Rio de Janeiro, v. 32, out./dez 2007, p. 8.

187 SILVA, Jorge Cesa Ferreira da. Inadimplemento das obrigações. São Paulo: Editora Revista dos Tribunais. 2007. p. 31.

${ }^{188}$ MARTINS-COSTA, Judith. Comentários ao novo Código Civil. Rio de Janeiro: Forense. 2004. p. 82.
} 
A doutrina atualmente conceitua inadimplemento (em sentido amplo) como "a situação objectiva de não realização da prestação debitória, independentemente da causa de onde ela procede" ${ }^{\prime 189}$. Observe-se, todavia, que nem sempre que a prestação deixa de ser efetuada há inadimplemento. Pode suceder, por exemplo, de o direito do credor prescrever ou dele remitir (perdoar) a dívida, ou haver confusão das figuras do devedor e do credor.

Desta feita, somente estará caracterizado o inadimplemento quando, não tendo sido extinta a obrigação por outra causa, a prestação não é efetuada, nem pelo devedor, nem por terceiro. A esse respeito, Antunes Varela assevera que o inadimplemento "pode assim definir-se, com maior propriedade, como a não realização da prestação debitória, sem que entretanto se tenha satisfeito (por outra via) o direito do credor ou cumprido o dever de prestar a cargo do obrigado"190.

É importante observar que essa concepção ampla de inadimplemento abrange todos os casos em que a prestação devida não é realizada pela outra parte contratante (exemplo: o livro que A deveria entregar para B não existe mais), independentemente da causa do descumprimento da obrigação, isto é, sendo ela imputável ao devedor (exemplo: A, que brigou com B, queima o livro, exemplar único) ou não imputável (exemplo: a biblioteca de A, onde guardado o livro na espera da chegada do tempo em que, pelo contrato, deveria prestar, sofre uma inundação, consequente à excepcional enchente que atingiu o local onde localizada, destruindo todos os livros ali guardados) ${ }^{191}$.

Conforme observa Antunes Varela ${ }^{192}$, em determinadas situações, o inadimplemento decorre de fato imputável ao devedor (exemplo: A vende para $\mathrm{C}$ o automóvel que havia se comprometido a vender para B). Outras vezes, o inadimplemento procede de fato de terceiro (exemplo: $\mathrm{C}$ bate e causa a destruição total do automóvel que $\mathrm{A}$ havia se comprometido a vender para B), de caso fortuito ou força maior (exemplo: caí um raio sobre o veículo que A havia se comprometido a vender para B), da própria lei (que proíbe, por hipótese, a realização do negócio jurídico prometido) ou até do credor (que se

\footnotetext{
${ }^{189}$ VARELA, João de Mattos Antunes. Das obrigações em geral. Coimbra: Almedina, 1970. p. 734. ${ }^{190}$ VARELA, João de Mattos Antunes. Das obrigações em geral. Coimbra: Almedina, 1970. p. 735.

${ }^{191}$ MARTINS-COSTA, Judith. Comentários ao novo Código Civil. Rio de Janeiro: Forense. 2004. p. 82-83.

${ }^{192}$ VARELA, João de Mattos Antunes. Das obrigações em geral. Coimbra: Almedina. 1970. p. 735.
} 
recusou a cooperação indispensável à realização da prestação). No entanto, como os efeitos de uma ou outra situação são totalmente diversos, é preciso buscar uma definição estrita de inadimplemento.

É por essa razão que a doutrina costuma diferenciar as modalidades de inadimplemento quanto à sua causa: inadimplemento imputável ao devedor e inadimplemento inimputável (não imputável) ao devedor ${ }^{193}$. No primeiro caso, a inexecução da obrigação decorre de ato ou fato atribuível ao devedor; no segundo caso, a inexecução decorre "de fato necessário, que o devedor não pode evitar ou impedir" "194. São exemplos de causas de inadimplemento não imputáveis ao devedor aquelas situações em que a impossibilidade superveniente da prestação "derive, quer de facto do credor, quer de caso fortuito ou de força maior" ${ }^{\prime 195}$.

A esse respeito, Luis Diez-Picazo e Antonio Gullon comentam que:

En principio, lo normal es que la imputabilidad y la responsabilidad de la infracción del derecho de crédito se examinen respecto del deudor. Sin embargo, cabe también la posibilidad de que el impedimento o el obstáculo puesto a la prestación o al logro de una plena satisfacción a través de la misma haya serle imputado al acreedor o incluso a un tercero ajeno a la obligación o, en fin, que no le pueda ser imputado a nadie, por obedecer a un hecho fortuito, inevitable e imprevisible. $^{196}$

Judith Martins-Costa também sistematiza de maneira precisa a questão:

A summa divisio em matéria de inadimplemento é a que discerne entre a sua causa, isto é, se a prestação devida não se realizou por fato imputável ao devedor ou por fato não imputável do devedor. Como o exame da imputabilidade resta melhor situado no comentário ao art. 396, basta, por ora, fixar que só no caso do incumprimento imputável existe um verdadeiro e característico não-

\footnotetext{
${ }^{193}$ VARELA, João de Mattos Antunes. Das obrigações em geral. Coimbra: Almedina. 1970. p. 735.

${ }^{194}$ GOMES, Orlando. Obrigações. Revista, atualizada e aumentada, de acordo com o Código Civil de 2002, por Edvaldo Brito. Rio de Janeiro: Forense. 2005. p. 170.

${ }^{195}$ ALMEIDA COSTA, Mário Júlio de. Noções de direito civil. Coimbra: Livraria Almedina. 1980. p. 228. 196 DIEZ-PICAZO, Luis e GULLON, Antonio. Sistema de derecho civil. v. II. Madrid: Editorial Tecnos. 1978. p. 166. Em tradução livre: "Em princípio, o normal é que a imputabilidade e a responsabilidade pela infração ao direito de crédito sejam examinadas em relação ao devedor. No entanto, também é possível que o impedimento ou obstáculo à prestação ou à plena satisfação seja imputado ao credor ou mesmo a um terceiro estranho à obrigação ou, por fim, que não possa ser atribuído a ninguém, por decorrer de um caso fortuito, inevitável e imprevisível."
} 
cumprimento. Quando não-imputável, teremos uma hipótese de impossibilidade e o efeito será extintivo da relação obrigacional. ${ }^{197}$

Assim, quando há o inadimplemento de uma obrigação, duas hipóteses podem ocorrer: ou o inadimplemento é inimputável ao devedor, e resulta simplesmente a extinção da obrigação e o retorno das partes ao status quo, sem outras consequências, nos termos do artigo 393 do Código Civil ${ }^{198}$, salvo se a parte tiver assumido contratualmente a responsabilidade por atos ou fatos que não lhe sejam imputáveis; ou o devedor é responsável pelo não cumprimento da obrigação ${ }^{199}$, e então cabe ao credor invocar a aplicação dos efeitos previstos no artigo 389 do Código Civil ${ }^{200}$.

Diante dessa diferenciação entre as modalidades de inadimplemento quanto à sua causa, afirma-se que inadimplemento não é a simples ausência de cumprimento da prestação devida. Inadimplemento em sentido estrito constitui a não realização da prestação devida, enquanto devida, na medida em que essa falta de cumprimento corresponde à violação de norma legal, convencional ou imposta pelos usos e costumes, que era especificamente dirigida ao devedor, cominando o dever de prestar ou, ao credor, cominando o dever de receber e o dever de colaborar para o adimplemento ${ }^{201}$.

Portanto, o inadimplemento que acarreta os efeitos previstos no artigo 389 do Código Civil (pagamento de perdas e danos, juros, correção monetária e honorários de

\footnotetext{
${ }^{197}$ MARTINS-COSTA, Judith. Comentários ao novo Código Civil. Rio de Janeiro: Forense. 2004. p. 147. No mesmo sentido, Almeida Costa assevera que "[...] as várias causas do não cumprimento produzem diferentes consequências jurídicas: enquanto que umas determinam a pura extinção do vínculo obrigacional, outras constituem o devedor em responsabilidade indemnizatória e conduzem à realização coactiva da prestação; e outras, ainda, deixam basicamente inalterado o vínculo obrigacional, sem agravarem a responsabilidade do devedor, podendo até verificar-se um direito de indemnização deste contra o credor. Daí porque a nossa lei discipline, em separado, a impossibilidade do cumprimento e mora não imputáveis ao devedor (arts. 790 a 797), a falta de cumprimento e mora imputáveis ao devedor (arts. 798 a 812), e a mora do credor (arts. 813 a 816)". ALMEIDA COSTA, Mário Júlio de. Noções de direito civil. Coimbra: Livraria Almedina. p. $220-221$. 198 “Art. 393. O devedor não responde pelos prejuízos resultantes de caso fortuito ou força maior, se expressamente não se houver por eles responsabilizado."

${ }^{199}$ PEREIRA, Caio Mário da Silva. Instituições de direito civil. v. II. 20. ed. Rio de Janeiro: Forense. 2005. p. 323.

${ }^{200}$ Conforme observa Pontes de Miranda, "o ônus da prova da não-imputabilidade toca ao devedor". PONTES DE MIRANDA, Francisco Cavalcanti. Tratado de direito privado. tomo XXIII. São Paulo: Editora Revista dos Tribunais. p. 256.

${ }^{201}$ MARTINS-COSTA, Judith. Comentários ao novo Código Civil. Rio de Janeiro: Forense. 2004. p. 83-84.
} 
advogado) - que será doravante denominado inadimplemento em sentido estrito - é o inadimplemento da prestação devida, enquanto devida a prestação.

\subsubsection{Imputabilidade e Culpa}

Como visto, inadimplemento em sentido estrito significa o não cumprimento imputável da prestação devida, enquanto devida. Quando se exige a imputabilidade para configuração do inadimplemento e para a atribuição da responsabilidade ao inadimplente, fica a dúvida a respeito do que configuraria a responsabilidade. Em outras palavras, fica a dúvida sobre se a culpa é ou não elemento essencial da imputabilidade ${ }^{202}$.

Segundo Luis Diez-Picazo e Antonio Gullon, o inadimplemento contratual pressupõe a culpa ou o dolo do devedor e "la falta de cumplimiento ha de ser voluntaria", sendo que "la culpa del deudor se presume iuris tantum" (ou seja, é uma presunção relativa $)^{203}$.

$\mathrm{Na}$ doutrina tradicional do direito brasileiro, que ainda parece ser a majoritária $^{204}$, o inadimplemento está intrinsecamente relacionado à ideia de culpa (em sentido amplo) no descumprimento da obrigação. Para essa corrente doutrinária ${ }^{205}$, o

\footnotetext{
${ }^{202}$ Fernando Noronha afirma que "nexo de imputação é o fundamento, ou a razão de ser da atribuição da responsabilidade a uma determinada pessoa, pelos danos ocasionados ao patrimônio ou à pessoa de outra, em consequência de um determinado fato antijurídico. É o elemento que aponta o responsável, estabelecendo a ligação do fato danoso com este". NORONHA, Fernando. Direito das obrigações. v. I. São Paulo: Saraiva. 2013. p. 495-496.

${ }^{203}$ DIEZ-PICAZO, Luis; GULLON, Antonio. Sistema de derecho civil. v. II. Editorial Tecnos. p. 156.

${ }^{204}$ A questão de se o adimplemento pressupõe a culpa de uma das partes contratantes é tema bastante discutido na doutrina. Os doutrinadores costumam apontar o inadimplemento como acontecimento imputável ao devedor. Todavia, a doutrina discute se esta imputabilidade será sempre culposa ou não. O entendimento que parece predominar é o de que a culpa é pressuposto do inadimplemento. A esse respeito, confiram-se os ensinamentos de Judith Martins-Costa: "A doutrina (e não só a brasileira) está separada em dois grupos no que diz respeito à questão acima arguida. No primeiro, estão juristas de porte de Clóvis do Couto e Silva, Ruy Rosado de Aguiar Jr., Agostinho Alvim, Sílvio Rodrigues, Serpa Lopes e Clóvis Beviláqua para quem a imputabilidade é sempre culposa. No outro grupo estão juristas de não menor porte, como Pontes de Miranda, Araken de Assis, Mário Júlio de Almeida Costa, que discernem entre imputabilidade e culpa." MARTINS-COSTA, Judith. Comentários ao novo Código Civil. Rio de Janeiro: Forense. 2004. p. 84-85.

${ }^{205}$ É essa a posição de Orlando Gomes a respeito da questão:

"O inadimplemento da obrigação por fato imputável ao devedor deve ser apreciado à luz da teoria da culpa contratual.

Consiste a culpa na infração de dever jurídico oriundo de contrato, praticada intencional ou negligentemente. Não deve ser confundida com a culpa aquiliana, na qual se funda a responsabilidade delictual. A culpa a ser
} 
inadimplemento sempre decorreria da violação de um dever contratual ou legal correspondente a uma conduta faltosa de uma das partes contratantes.

Ao examinar o artigo 963 do Código Civil de 1916 - "não havendo fato ou omissão imputável ao devedor, não incorre este em mora" - à qual corresponde, ipsis litteris, a regra do artigo 396 do atual Código Civil, Clóvis V. do Couto e Silva afirmou que:

\begin{abstract}
Conforme este artigo, somente poderá haver mora quando houver fato ou omissão imputável ao devedor. Cuida-se aí da mora debitoris. Esse artigo expressa uma regra geral da qual se pode tirar consequência semelhante à da alínea II do $\$ 275$ do BGB. Se somente existe mora com fato imputável ao devedor, não se pode chegar a uma solução jurídica na qual se manifesta uma forma de mora sem culpa. ${ }^{206}$
\end{abstract}

Agostinho Alvim também asseverou que o inadimplemento - mais especificamente, a mora do devedor - pressupõe a culpa do devedor ao comentar o mesmo dispositivo legal:

A culpa é elementar na mora do devedor, como seu elemento subjetivo.

É da associação dos arts. 955 e 963 que resulta, em nosso direito, o conceito da mora solvendi.

Este ponto é pacífico na doutrina e na jurisprudência, registrando esta os mais variados casos de devedores absolvidos por ausência de culpa, não obstante a existência de qualquer das circunstâncias objetivas da mora. [...]

Pondere-se, ademais, que a doutrina, segundo a qual não há mora sem culpa, sobre ser a melhor, é tradicional em nosso direito. ${ }^{207}$

Outra corrente doutrinária considera não ser a culpa elemento essencial da imputabilidade $^{208}$. Conforme aponta J. W. Hedemann, a culpa é um importante ponto de

considerada no capítulo da inexecução é restrita a infrações que determinam inadimplemento da obrigação contratual." GOMES, Orlando. Obrigações. Revista, atualizada e aumentada, de acordo com o Código Civil de 2002, por Edvaldo Brito. Rio de Janeiro: Forense. 2005. p. 170.

No mesmo sentido, Carlos Roberto Gonçalves: “A redação do art. 389, supratranscrito, pressupõe o não cumprimento voluntário da obrigação, ou seja, culpa. Em princípio, pois, todo inadimplemento presume-se culposo [...].” GONÇALVES, Carlos Roberto. Direito civil brasileiro. v. 2: Teoria geral das obrigações. 8. ed. São Paulo: Saraiva. 2011. p. 371.

${ }^{206}$ SILVA, Clóvis do Couto e. A obrigação como processo. Rio de Janeiro: Editora FGV. 2006. p. 100.

${ }^{207}$ ALVIM, Agostinho. Da inexecução das obrigações e suas consequências. 3. ed. atual. Rio de Janeiro: Editora Jurídica e Universitária Ltda., 1949. p. 19.

${ }^{208}$ Nesse sentido: ALMEIDA COSTA, Mário Júlio. Direito das obrigações. 9, ed. Coimbra: Almedina, 2001. p. 969 et seq.; PONTES DE MIRANDA, Francisco Cavalcanti. Tratado de direito privado. tomo XXIII. São Paulo: Editora Revista dos Tribunais. p. 253; ASSIS, Araken de. Resolução do contrato por inadimplemento. 
partida para o estudo do inadimplemento, mas não é o único, haja vista que em alguns casos de inadimplemento "este concepto de la culpa es sobrepasado, imponiendo al deudor una responsabilidad excepcional por simple ‘caso fortuito' (cfr. supra $\S 13$ IV al final) o imputándole la culpa de las personas auxiliares de que se sirve para el cumplimiento (V. seguidamente IV). Para incluir todos estos casos en una expresión sintética el legislador ha formulado el concepto de 'responsabilidad obligatoria' ('Vertretenmüssen'),209.

Partindo dessa mesma observação, Pontes de Miranda discerne entre o princípio da imputabilidade e o princípio da culpa, afirmando que "o Código Civil brasileiro afastou-se da teoria da culpa no inadimplemento" e que "certamente, a culpa não é elemento necessário do suporte fático do art. 963 [correspondente ao artigo 396 do atual Código Civil], que diz: 'não havendo fato ou omissão imputável ao devedor, não incorre êsse em mora"; portanto, salvo se há regra especial que exija a culpa, ou a culpa grave, ou o dolo, basta a imputabilidade" 210 .

Almeida Costa também faz essa distinção entre culpabilidade e imputabilidade. A par de situar a regra geral segundo a qual "o devedor que falta culposamente ao cumprimento da obrigação se torna responsável pelos prejuízos que causa ao credor" ${ }^{211}$, o jurista português alude à possibilidade de descumprimento não culposo e mesmo assim imputável ao devedor, na hipótese desse prometer o cumprimento da obrigação "haja o que houver", como ocorre em certas obrigações de resultado e nas obrigações de garantia, nas quais assume o risco da não verificação do efeito pretendido ${ }^{212}$.

4. ed., São Paulo: Revista dos Tribunais. 2004. p. 118. MARTINS-COSTA, Judith. Comentários ao novo Código Civil. Rio de Janeiro: Forense. 2004. p. 85 et seq.; e SAVI, Sérgio. Inadimplemento das Obrigações, Mora e Perdas e Danos. In: TEPEDINO, Gustavo. Obrigações: estudos na perspectiva civil-constitucional. Rio de Janeiro: Renovar. 2005. p. 465 et seq.

${ }^{209}$ HEDEMANN, J.W. Derecho de obligaciones. v. III. Trad. de Jaime Santos Briz. Madrid: Editorial Revista de Derecho Privado. 1958. p. 159. Em tradução livre: "este conceito de culpa é ultrapassado, impondo ao devedor a responsabilidade excepcional por simples 'caso fortuito' (cfr. supra $\S 13$ IV final) ou imputando-lhe a culpa dos auxiliares (v. IV abaixo ). Para incluir todos estes casos, o legislador formulou o conceito de responsabilidade obrigatória ('Vertretenmüssen')." No mesmo sentido: LARENZ, Karl. Derecho de obligaciones. tomo I. Trad. de Jaime Santos Briz, Madrid: Editora Revista de Derecho Privado. 1958. p. 283.

${ }^{210}$ PONTES DE MIRANDA, Francisco Cavalcanti. Tratado de direito privado. tomo XXIII. São Paulo: Editora Revista dos Tribunais. p. 253-254.

${ }^{211}$ ALMEIDA COSTA, Mário Júlio. Direito das obrigações. 9. ed. Coimbra: Almedina. 2001. p. 969.

${ }^{212}$ ALMEIDA COSTA, Mário Júlio. Direito das obrigações. 9. ed. Coimbra: Almedina. 2001. p. 971-972. 
Mais recentemente, Araken de Assis, com apoio em Pontes de Miranda e em rica bibliografia italiana, critica a doutrina majoritária para afirmar que, ao inadimplemento relativo (mora), "basta, assim, a atribuição do ato omissivo ou comissivo ao devedor, dele resultando antagonismo com a conduta devida, e atendendo-se a que pode ocorrer mora sem culpa". No entanto, apesar do autor sustentar que o inadimplemento não decorre sempre e necessariamente de culpa, ele afirma que "em regra, e a essa realidade não se pode fechar os olhos, a conduta do obrigado se revela mesmo culpável, restringindo-se a alguns casos raros e isolados, a singela imputabilidade" 213 .

Ressalvando a respeitável doutrina que, mesmo reconhecendo a distinção entre os princípios da imputabilidade e da culpabilidade, afirma que essa distinção assume pouca relevância prática, entendemos que, apesar da responsabilidade civil subjetiva ainda ser a regra geral no atual Código Civil, a cláusula geral de responsabilidade objetiva prevista no parágrafo único do artigo 927 do Código Civil ${ }^{214}$ e os casos cada vez mais frequentes ${ }^{215}$ de responsabilidade contratual objetiva apontam uma tendência do direito brasileiro de ampliar as hipóteses em que a responsabilidade contratual decorrem de um nexo de imputação e não de uma inculpação ${ }^{216}$.

213 ASSIS, Araken de. Resolução do contrato por inadimplemento. 4. ed. São Paulo: Revista dos Tribunais. 2004. p. 101. Com orientação semelhante, Jorge Cesa Ferreira da Silva afirma que, diante da objetivação da noção de culpa, "a discussão travada acerca da necessidade de culpa para a mora do devedor, levada a rigor extremo, esteriliza-se, passando a refletir, em certa medida, apenas um rebuscado jogo de palavras". SILVA, Jorge Cesa Ferreira da. A boa-fé e a violação positiva do contrato. Rio de Janeiro: Renovar. 2002. p. 154.

214 “Art. 927. Aquele que, por ato ilícito (arts. 186 e 187), causar dano a outrem, fica obrigado a repará-lo.

Parágrafo único. Haverá obrigação de reparar o dano, independentemente de culpa, nos casos especificados em lei, ou quando a atividade normalmente desenvolvida pelo autor do dano implicar, por sua natureza, risco para os direitos de outrem."

${ }^{215}$ De fato, são cada vez mais frequentes no direito brasileiro as hipóteses de responsabilidade objetiva. Exemplificativamente: a responsabilidade das estradas de ferro (Decreto 2.681/1912, artigo 26); a responsabilidade do empresário pelos danos causados aos produtos postos em circulação (Código Civil, artigo 931); a responsabilidade pelo fato de coisa (Código Civil, artigo 938); os casos de responsabilidade pelo fato de outrem enumerados no artigo 932, incisos I a V, do Código Civil; a responsabilidade por acidentes de trabalho (Constituição Federal, artigo 7, inciso XXVIII, Lei no 8.213/91 e Decreto 2.172/97); a responsabilidade civil do Estado (Constituição Federal, artigo 37, parágrafo $6^{\circ}$ ); a responsabilidade por danos ao meio ambiente (Lei $\mathrm{n}^{\circ}$ 6.938/81, artigo 14, parágrafo $1^{\circ}$ ); a responsabilidade por danos nucleares (Constituição Federal, artigo 21, inciso XXIII); e a responsabilidade do fornecedor nas relações de consumo (Código de Defesa do Consumidor, Lei no 8.078/90).

${ }^{216}$ Em estudo abrangente sobre a questão, Giselda Hironaka destaca que "não resta dúvida, mesmo, de que há uma extraordinária urgência em se construir, na ambiência do direito positivo da responsabilidade civil, uma regra que seja suficientemente geral e abrangente, capaz de recepcionar as hipóteses já conhecidas de danos injustos que devam ser reparados ou indenizados, assim como que seja capaz de recepcionar, também, as hipóteses de outras ocorrências danosas, relacionadas a um porvir prejudicial. Porque, afinal de contas, tratase de evitar o dano injusto, entendendo-se que um dano civil pode ser injusto tanto por haver sido 
Com efeito, diante da diversidade de hipóteses de responsabilidade contratual objetiva previstas no ordenamento jurídico brasileiro (principalmente após o Código Civil de 2002 estabelecer expressamente uma cláusula geral de responsabilidade objetiva), é impossível restringir o inadimplemento contratual à noção de culpa. Embora em muitos casos a culpa ainda seja o pressuposto do inadimplemento, ela não é o único. O inadimplemento pode também decorrer de um nexo de imputação, decorrente de lei ou de contrato, que prevê uma responsabilidade objetiva das partes contratantes.

Claudio Luiz Bueno de Godoy observa que:

[...] o novo Código, ao cuidar da responsabilidade civil, além de manter a culpa como elemento de atribuição da obrigação de indenizar, o que se contém no art. 927, caput, ao lado dela erigiu uma regra também geral de responsabilidade objetiva, aqui compreendida como independente de culpa. É a disposição do parágrafo único do mesmo artigo, já antes transcrito. E, mais, se de disposição genérica se tratou, nem se concebe a responsabilidade sem culpa como hipótese exceptiva em sistema, o do novo Código Civil, que se poderia dizer ainda predominantemente aquiliano. A nova legislação cedeu à tendência, já referida, de multiplicidade de critérios de imputação da responsabilidade civil, a ponto de estabelecer cláusula geral da responsabilidade sem culpa no caso de atividade que crie risco, além de outras hipóteses igualmente casuísticas em que se prescinde da avaliação da culpa. Por isso, porque se diversificam nexos de imputação da responsabilidade, é que, a rigor, segundo se entende, descabe procurar uma hierarquia entre esses critérios, mesmo no texto do Código Civil de $2002 .^{217}$

Vale mencionar que atualmente existem diversas hipóteses de imputação objetiva no ordenamento jurídico brasileiro, que evidenciam que a culpa não é mais o único pressuposto da responsabilidade contratual ${ }^{218}$. A título de exemplo, cite-se o contrato

injustamente causado como pelo fato de ser injusto que o suporte quem o sofreu. Assim, construída, a regra idealizada portaria o atributo equivalente a um fundamento geral da responsabilidade civil contemporânea, de sorte a se instalar não apenas além da concepção de culpa, mas também da própria concepção de risco, tal como consagrada até agora, na doutrina nacional e alienígena. Instalar-se-ia - uma tal regra - como princípio fundante de caráter geral da responsabilidade civil, independentemente de culpa de quem quer que seja, cuja auto-sustentabilidade se daria apenas pela efetiva produção de um dano injusto, em desfavor da vítima, ancorando-se para além da pontuação legal casuística de responsabilização objetiva e revelando, como causa final almejada, a concretização dos paradigmas do injusto e do equânime”. HIRONAKA, Giselda Mari Fernandes Novaes. Responsabilidade pressuposta. Belo Horizonte: Del Rey, 2005. p. 353-354.

${ }^{217}$ GODOY, Claudio Luiz Bueno de. Responsabilidade civil pelo risco da atividade: uma cláusula geral no Código Civil de 2002. 2. ed. São Paulo: Saraiva. 2010. p. 43.

${ }^{218}$ Para um estudo aprofundado do tema, recomenda-se a leitura do capítulo 5 do livro: GODOY, Claudio Luiz Bueno de. Responsabilidade civil pelo risco da atividade: uma cláusula geral no Código Civil de 2002. 2. ed. São Paulo: Saraiva. 2010. 
de transporte de pessoas, pelo qual o transportador se obriga a levar uma pessoa e a sua bagagem até o seu destino, com total segurança, mantendo incólumes os seus aspectos físicos e patrimoniais. A obrigação assumida pelo transportador é sempre de resultado, diante dessa cláusula de incolumidade, o que fundamenta a sua responsabilização independentemente de culpa ${ }^{219}$. Essa responsabilidade objetiva é evidenciada pelo art. 734 do Código Civil ${ }^{220}$, que estabelece que o transportador somente não responde nos casos de força maior.

Também pode ser mencionada a hipótese prevista no artigo 535 do Código Civil $^{221}$. Trata-se do contrato estimatório, no qual o consignatário não se exonera da obrigação de pagar o preço se a restituição da coisa, em sua integralidade, tornar-se impossível, “ainda que por fato a ele não imputável”. É um caso em que há atribuição de responsabilidade mesmo por ato ou fato que não tenha sido causado culposamente pelo consignatário, o que reforça a tese de que imputação não se confunde com inculpação ${ }^{222}$.

O Código de Defesa do Consumidor, ao disciplinar a responsabilidade civil por vício ou por fato do produto ou serviço em seus artigos 12 a 20, também estabeleceu a responsabilidade objetiva como critério de imputação da responsabilidade dos fornecedores, "derivada da objetiva constatação de uma quebra da qualidade do produto ou

\footnotetext{
${ }^{219}$ Carlos Roberto Gonçalves afirma que "o contrato de transporte gera, para o transportador, obrigação de resultado, qual seja, a de transportar o passageiro são e salvo, e a mercadoria, sem avarias, ao seu destino. A não obtenção desse resultado importa o inadimplemento das obrigações assumidas e a responsabilidade pelo dano ocasionado. Não se eximirá da responsabilidade provando apenas ausência de culpa. Incumbe-lhe o ônus de demonstrar que o evento danoso se verificou por culpa exclusiva da vítima, força maior ou ainda por fato exclusivo de terceiro. Denomina-se cláusula de incolumidade a obrigação tacitamente assumida pelo transportador de conduzir o passageiro incólume ao local do destino". GONÇALVES, Carlos Roberto. Direito civil brasileiro. v. 3: Contratos e atos unilaterais. 9. ed. São Paulo: Saraiva. 2012. p. 480. Neste sentido: "A responsabilidade do transportador é objetiva, nos termos do art. 750 do CC/2002, podendo ser elidida tão somente pela ocorrência de força maior ou fortuito externo, isto é, estranho à organização da atividade". (STJ, AgRg no REsp 1285015, Rel. Min. Ministro Antonio Carlos Ferreira, j. 11/06/2013)

220 “Art. 734. O transportador responde pelos danos causados às pessoas transportadas e suas bagagens, salvo motivo de força maior, sendo nula qualquer cláusula excludente da responsabilidade."

221 “Art. 535. O consignatário não se exonera da obrigação de pagar o preço, se a restituição da coisa, em sua integralidade, se tornar impossível, ainda que por fato a ele não atribuível."

${ }^{222}$ MARTINS-COSTA, Judith. Comentários ao novo Código Civil. Rio de Janeiro: Forense, 2004. p. 271272.
} 
do serviço posto em circulação, superando a dicotomia existente entre a origem contratual ou aquiliana da obrigação de indenizar,"223.

Os Tribunais brasileiros também têm reconhecido com frequência hipóteses de responsabilidade objetiva, o que se evidencia, por exemplo, com a súmula 479 do Superior Tribunal de Justiça, segundo a qual "as instituições financeiras respondem objetivamente pelos danos gerados por fortuito interno relativo a fraudes e delitos praticados por terceiros no âmbito de operações bancárias" 224 , e com o entendimento jurisprudencial de que a operadora de plano de saúde responde objetivamente perante o consumidor em caso de erro médico quando presta o serviço por meio de hospital próprio ou por médicos e hospital credenciados ${ }^{225}$.

Os exemplos acima mencionados revelam que existe um sistema dualista da responsabilidade (subjetiva e objetiva) civil no direito brasileiro, de maneira que nem sempre o inadimplemento resulta de uma imputabilidade subjetiva (culposa), existindo diversos casos de imputação objetiva que, à vista do artigo 927, parágrafo único, do Código Civil, só tendem a crescer $^{226}$. Assim, concordamos com a afirmação de Judith Martins-Costa de que "imputar não é inculpar, não é atribuir culpa, é atribuir

${ }^{223}$ GODOY, Claudio Luiz Bueno de. Vícios do produto e do serviço. In: LOTUFO, Renan; MARTINS, Fernando Rodrigues (Coord.). 20 anos do Código de Defesa do Consumidor: conquistas, desafios e perspectivas. São Paulo: Saraiva. 2011. p. 37.

${ }^{224}$ Neste sentido: "Tratando-se de consumidor direto ou por equiparação, a responsabilidade da instituição financeira por fraudes praticadas por terceiros, das quais resultam danos aos consumidores, é objetiva e somente pode ser afastada pelas excludentes previstas no CDC, como por exemplo, culpa exclusiva da vítima ou de terceiro" (REsp. 1.1199.782, jul. sob o rito do artigo 543-C, rel. Min. Luis Felipe Salomão, SEGUNDA SEÇÃO, julgado em 24/08/2011, DJe 12/09/2011).

${ }^{225}$ Neste sentido: "a operadora do plano de saúde, na condição de fornecedora de serviço, responde perante o consumidor pelos defeitos em sua prestação, seja quando os fornece por meio de hospital próprio e médicos contratados ou por meio de médicos e hospitais credenciados, nos termos dos arts. $2^{\circ}, 3^{\circ}, 14$ e 34 do Código de Defesa do Consumidor, art. 1.521, III, do Código Civil de 1916 e art. 932, III, do Código Civil de 2002. Essa responsabilidade é objetiva e solidária em relação ao consumidor, mas, na relação interna, respondem o hospital, o médico e a operadora do plano de saúde nos limites da sua culpa" (REsp 866371, Rel. Ministro Raul Araújo, j. 27/03/2012).

${ }^{226}$ Anderson Schreiber afirma que "a cláusula geral de responsabilidade objetiva por atividades de risco demonstra a importância que a noção de risco apresenta para esta espécie de responsabilidade. De fato, foi sobretudo com base na idéia de que uma pessoa deve responder pelos riscos derivados de sua atividade (culposa ou não) que a responsabilidade objetiva logrou atrair adeptos em todos os ordenamentos, encerrando o império exclusivo da culpa, no que já foi definido como uma "tripla liberação"'. SCHREIBER, Anderson. Novos paradigmas da responsabilidade civil. São Paulo: Atlas. 2007. p. 27. 
responsabilidade. Responsabilizar é imputar, não é necessariamente inculpar". ${ }^{227}$ Daí concluir-se que a culpa não é elemento essencial e indispensável do inadimplemento, mas sim a imputabilidade ${ }^{228}$.

Na doutrina estrangeira, J. W. Hedemann também afirma que:

[...] en la doctrina de la mora no se dice, por ejemplo: "La mora no es imputable al deudor si éste no ha tenido culpa en la omisión de la prestación, sino: 'El deudor no incurre en mora en tanto la prestación no haya sido cumplida a causa de una circunstancia de la que no ha de responder"” (\$285). Con esta forma de expresarse, se incluyen al mismo tempo los supuestos de hecho en que al deudor, aun sin 'culpa' por su parte, le es exigida, sin embargo, una responsabilidad. ${ }^{229}$

Para sistematizar a questão do pressuposto para o inadimplemento, filiamo-nos ao critério geral "imputabilidade" proposto por Judith Martins-Costa, no qual existe uma dupla forma de imputação de responsabilidade: (a) a imputação subjetiva, regida pelo princípio da inculpação (requerendo ato culposo - em sentido estrito - no suporte fático da responsabilidade pelo não cumprimento); e (b) a imputação objetiva, resultante das normas que atribuem a alguém a assunção de um risco ou de um dever de segurança, ou de garantia, ou a responsabilização pela confiança despertada na outra parte, independentemente de qualquer exame da culpa ${ }^{230}$.

\footnotetext{
${ }^{227}$ MARTINS-COSTA, Judith. Comentários ao novo Código Civil. Rio de Janeiro: Forense. 2004. p. 87-88. ${ }^{228}$ Nesse sentido: LÔBO, Paulo. Direito civil: obrigações. 3. ed. São Paulo: Saraiva. 2013. p. 240.

${ }^{229}$ HEDEMANN, J.W. Derecho de obligaciones. v. III. Trad. de Jaime Santos Briz. Editorial Revista de Derecho Privado: Madrid, 1958. p. 159. Em tradução livre: "na doutrina da mora não se diz, por exemplo: 'a mora não é imputável ao devedor se ele não teve culpa na omissão da prestação', mas 'O devedor não está em mora se a prestação não tiver sido cumprida em virtude de uma circunstância pela qual ele não responde' (§285). Com essa forma de se expressar, se incluem ao mesmo tempo os pressupostos de fato em que se exige ao devedor, mesmo que sem culpa, uma responsabilidade".

230 MARTINS-COSTA, Judith. Comentários ao novo Código Civil. Rio de Janeiro: Forense. 2004. p. 88. No mesmo sentido: "diz-se imputável o inadimplemento cujas consequências podem ser atribuídas ao devedor. Pode ser que essa imputabilidade (i) decorra de ter ele agido com culpa em sentido amplo (negligência, imprudência ou imperícia), caso em que o inadimplemento é imputável por ter sido culposo - também chamado de inadimplemento subjetivamente imputável -, (ii) ou decorra de uma imposição da norma jurídica, caso em que o inadimplemento é imputável não obstante a ausência de culpa do devedor - também conhecido como inadimplemento objetivamente imputável; exemplo desse último é o que se dá nas hipóteses em que a inexecução decorre de fato alheio e não imputável ao devedor, como o caso fortuito ou a força maior, mas, ao tempo do evento alheio à sua vontade, já estava em mora (art. 399, CC), ou se o sujeito expressamente se responsabilizou por arcar com as consequências do caso fortuito ou da força maior (art. 393, CC)." (DIDIER JR., Fredie; CUNHA, Leonardo Carneiro da; BRAGA, Paula Sarno; OLIVEIRA, Rafael Alexandria de. Curso de direito processual civil 5. 6. ed. Salvador. Editora JusPodivm. 2014. p. 92)
} 
A nosso ver, a sistematização proposta por Judith Martins-Costa tem a grande vantagem de, ao invés de utilizar um critério regra/exceção (em que a culpa seria a regra e o risco, a garantia, a segurança, etc. seriam as exceções), propor um critério único de atribuição de responsabilidade contratual, qual seja, o nexo de imputação, que possui duas espécies: a imputação subjetiva e a imputação objetiva.

O que importa é existir um nexo de imputação, uma razão de ser da atribuição da responsabilidade a uma determinada pessoa, pelos danos ocasionados ao patrimônio ou a outrem, que pode ser a culpa, a cláusula geral de responsabilidade prevista no art. $927, \S$ único, do Código Civil (risco da atividade), ou uma previsão legal ou contratual de responsabilidade objetiva. É à luz desse critério geral de imputação que propomos a análise do tema do inadimplemento contratual.

\subsubsection{Modalidades de inadimplemento (classificação conforme os efeitos)}

A doutrina costuma classificar o inadimplemento conforme os seus efeitos em inadimplemento absoluto e mora. Em linhas gerais, o critério distintivo dessas duas espécies de inadimplemento reside "na possibilidade ou não de receber a prestação",231, sendo que a possibilidade ou impossibilidade deve ser reconduzida ao credor e à sua utilidade para ele.

Genericamente, é possível afirmar que o inadimplemento absoluto ocorre quando há o descumprimento definitivo da obrigação, seja por ter se tornado impossível a prestação, seja por ter se tornado inútil ao credor. A mora (ou inadimplemento relativo), por sua vez, se verifica quando, embora a prestação não tenha sido executada pelo devedor no tempo, no lugar e na forma convencionados, ela ainda é possível e útil ao credor. Passar-se-á, agora, a analisar com maiores detalhes os conceitos de inadimplemento absoluto e mora.

\subsubsection{Inadimplemento absoluto: caracterização e efeitos}

\footnotetext{
231 ALVIM, Agostinho. Da inexecução das obrigações e suas consequências. 3. ed. atual. Rio de Janeiro: Editora Jurídica e Universitária Ltda. 1949. p. 45.
} 
Há inadimplemento absoluto quando a prestação devida, após o surgimento da obrigação, não puder mais ser realizada ou, podendo sê-lo, não mais interessa ao credor $^{232}$. A prestação é, portanto, irrecuperável. ${ }^{233}$ Duas são as circunstâncias que conduzem ao inadimplemento absoluto: a prestação que se tornou, objetivamente, impossível; ou a prestação que, embora possível, não é mais capaz de realizar os interesses objetivos do credor $^{234}$.

É hipótese de impossibilidade da prestação “quando esta não for realizável, em razão de barreiras de ordem física ou jurídica, seja por ter perecido, seja por exigir esforços extraordinários, injustificáveis em face das circunstâncias do vínculo concreto" ${ }^{235}$. Como exemplo da primeira hipótese de inadimplemento absoluto pode-se citar o caso de uma pessoa que se comprometeu a entregar um determinado cavalo de raça em data futura, mas que se viu impossibilitada de cumprir a obrigação porque o animal contraiu uma grave enfermidade, que poderia ter sido evitada se o animal tivesse sido adequadamente vacinado, e que culminou na sua morte. Neste exemplo, o objeto da prestação pereceu e, assim, a prestação não poderá ser cumprida definitivamente.

\footnotetext{
${ }^{232}$ Nesse sentido, Judith Martins-Costa: “O incumprimento definitivo significa que a prestação, que não foi prestada como devida não poderá mais sê-lo. Embora a doutrina costume subsumir todas as hipóteses em que a prestação não mais poderá ser cumprida na mesma etiqueta - 'incumprimento definitivo' - a verdade é que podemos divisar diferentes causas para essa definitividade da não prestação: ou a impossibilidade, ou a perda do interesse do credor, por inútil, então, a prestação." MARTINS-COSTA, Judith. Comentários ao novo Código Civil. Rio de Janeiro: Forense. 2004. p. 148. Confiram-se também as lições de Almeida Costa: "A primeira hipótese - também designada por inadimplemento propriamente dito ou impossibilidade definitiva ocorre quando a prestação, que ficou por cumprir na altura própria, não pode mais ser efectuada, tendo-se tornado impossível. Exemplificamos: A obriga-se para com B a entregar-lhe o objecto X, que perece; C não cumpre a obrigação que assumira de fornecer a D um banquete no dia Y, em que se celebrou o casamento da filha deste. Tanto num caso como no outro a obrigação não foi cumprida nem poderá vir a sê-lo. No segundo exemplo, a impossibilidade do cumprimento resulta de ter desaparecido o interesse do credor." ALMEIDA COSTA, Mário Júlio de. Noções de direito civil. Coimbra: Livraria Almedina. 1980. p. 219. James Eduardo de Oliveira afirma que "o inadimplemento absoluto representa um gole fatal que rompe de forma incontornável a relação contratual”. OLIVEIRA, James Eduardo de. Inadimplemento relativo e inadimplemento absoluto. In: ANDRIGHI, Fátima Nancy (Coord.). Responsabilidade civil e inadimplemento no direito brasileiro. São Paulo: Atlas. 2014. p. 179.

233 A expressão é de ASSIS, Araken de. Resolução do contrato por inadimplemento. 4. ed. rev. e atual. São Paulo: Editora Revista dos Tribunais. 2004. p. 102.

${ }^{234}$ AGUIAR JÚNIOR, Ruy Rosado de. Extinção dos contratos por incumprimento do devedor (resolução). 2. ed. Rio de Janeiro: Aide. 1991. p. 94-95.

235 SILVA, Jorge Cesa Ferreira da. Inadimplemento das obrigações. São Paulo: Editora Revista dos Tribunais. 2007. p. 36.
} 
A doutrina adota um conceito jurídico - e não lógico - de impossibilidade ${ }^{236}$, segundo o qual "o dever de prestar não pode ser exigido além de um limite razoável"237 e se admite como impossível a prestação cujo cumprimento exija do devedor esforço extraordinário e injustificável.

Orlando Gomes, valendo-se das lições de Hedemann ${ }^{238}$, afirma que o conceito de impossibilidade abrange a impossibilidade jurídica "stricto sensu" (é juridicamente impossível a prestação cujo cumprimento for obstado por proibição legal); a inexigibilidade econômica (a prestação que exige do devedor gasto absurdo, que o sacrifica inteiramente, sujeitando-o à perda material intolerável) e a inexigibilidade psíquica (prestação que para ser cumprida exige que o devedor se exponha a exagerado risco pessoal ou o obrigue a suportar intolerável constrangimento moral ${ }^{239}$.

Acrescente-se que a impossibilidade pode ser superveniente ao nascimento da obrigação ou pode estar presente ao tempo de sua constituição, caso em que a prestação desde o início não poderia ser fática ou juridicamente realizada. Para o estudo da teoria do inadimplemento somente interessa a impossibilidade superveniente, na medida em que a

\footnotetext{
${ }^{236}$ No que tange aos sentidos da palavra impossibilidade, J. W. Hedeman assevera que "Dos teorías se muestran como contrapuestas, de las cuales la segunda ha adquirido con el tempo un predominio absoluto. La primera arranca del concepto lógico (físico) de la 'imposibilidad'; por lo tanto, no habla de imposibilidad en tanto alguien pueda cumplir la prestación de cualquier modo que sea, incluso con las mayores dificultades y desproporcionados sacrificios. La otra teoría opone a este concepto lógico de la imposibilidad un 'concepto jurídico' de la misma, que es más flexible, y conduce a la interpretación del contrato oponiendo a la valoración lógica la razón práctica. Ello lleva a equiparar la 'imposibilidad' y la no exigibilidad de otra conducta. También se ha dicho que no puede ser exigido al deudor un esfuerzo 'superior al correspondiente a la obligación"”. HEDEMANN, J.W. Derecho de obligaciones. Vol. III. Trad. de Jaime Santos Briz. Editorial Revista de Derecho Privado: Madrid, 1958. p. 168. Em tradução livre: "Duas teorias são apresentadas como concorrentes, das quais a última prevaleceu. A primeira deriva do conceito lógico (físico) da impossibilidade; portanto, não fala em impossibilidade se alguém conseguir cumprir a obrigação de alguma forma, mesmo com as maiores dificuldades e sacrifícios desproporcionais. A outra teoria se opõe a esse conceito lógico de impossibilidade, com um "conceito legal " de impossibilidade, que é mais flexível, e leva à interpretação do contrato opondo a avaliação lógica a uma razão prática. Isto leva a equiparar a impossibilidade à inexigibilidade de comportamento. Também foi dito que não se pode exigir do devedor um esforço 'acima do valor da obrigação'."

${ }^{237}$ GOMES, Orlando. Obrigações. Revista, atualizada e aumentada, de acordo com o Código Civil de 2002 , por Edvaldo Brito. Rio de Janeiro: Forense. 2005. p. 172.

${ }^{238}$ HEDEMANN, J.W. Derecho de obligaciones. v. III. Trad. de Jaime Santos Briz. Madrid: Editorial Revista de Derecho Privado. 1958. p. 168-169.

${ }^{239}$ GOMES, Orlando. Obrigações. Revista, atualizada e aumentada, de acordo com o Código Civil de 2002, por Edvaldo Brito. Rio de Janeiro: Forense. 2005. p. 173-174.
} 
impossibilidade originária, conforme disposto no artigo 123, inciso I, do Código Civil ${ }^{240}$, atinge a própria validade do negócio jurídico, que será considerado nulo.

Saliente-se que o vício de nulidade somente atinge a impossibilidade originária (ou absoluta), assim considerada aquela que é a impossibilidade em si mesma e para todos. Quando a impossibilidade for subjetiva (ou relativa), por ser impossível apenas para o devedor, o ato será válido, sendo hipótese de incapacidade do devedor ${ }^{241}$. É o caso da venda de coisa alheia, ato ineficaz, mas válido, cuja prestação eventualmente poderá vir a ser cumprida, caso obtenha o devedor condições para efetivá-la ${ }^{242}$.

A segunda hipótese de inadimplemento absoluto é a extinção dos interesses do credor. Nesse caso, embora possível a prestação, afigura-se inútil para o credor $^{243}$. Destaque-se que a perda do interesse do credor deve necessariamente ocorrer depois da não realização da prestação no momento devido. Até o termo fixado no contrato, a eventual alteração dos interesses do credor não atinge a eficácia da obrigação. Todavia, se não adimplida a obrigação no momento devido, pode ocorrer que a obrigação não supra mais as necessidades do credor $^{244}$.

É o que acontece, por exemplo, com o vestido de noiva ou o bolo de casamento que ficam prontos depois da cerimônia de casamento. O cumprimento dessas obrigações

\footnotetext{
240 “Art. 123. Invalidam os negócios jurídicos que lhes são subordinados:

I - as condições física ou juridicamente impossíveis, quando suspensivas;"

241 “Art. 106. A impossibilidade inicial do objeto não invalida o negócio jurídico se for relativa, ou se cessar antes de realizada a condição a que ele estiver subordinado."

${ }^{242}$ AGUIAR JÚNIOR, Ruy Rosado de. Extinção dos contratos por incumprimento do devedor (resolução). 2. Ed. Rio de Janeiro: Aide. 1991. p. 97.

${ }^{243}$ Sobre essa questão, Luis Diez-Picazo e Antonio Gullon comentam que "se admite por la doctrina y jurisprudencia (Ss. de 5 de enero de 1935 y 6 de julio de 1945) que el retraso en el cumplimiento equivale a incumplimiento definitivo cuando ya no puede satisfacer el interés del acreedor; la prestación deja de serle útil. Especial relevancia tiene esta doctrina en los negocios con término esencial o a fecha fija, aunque su virtualidad no queda encerrada en ellos". DIEZ-PICAZO, Luis e GULLON, Antonio. Sistema de Derecho Civil. Volume II. Madrid: Editorial Tecnos. 1978. p. 162-163). Em tradução livre: “a doutrina e jurisprudência (Ss de 05 de janeiro de 1935 e 6 de Julho de 1945) entendem que o atraso no cumprimento equivale ao inadimplemento definitivo quando já não pode mais satisfazer o interesse do credor; porque a prestação lhe é inútil. Especial relevância tem esta doutrina em contratos com termo essencial ou data fixa, ainda que a sua aplicação não esteja limitada a eles,"

244 SILVA, Jorge Cesa Ferreira da. Inadimplemento das obrigações. São Paulo: Editora Revista dos Tribunais. 2007. p. 41.
} 
após o termo fixado no contrato ainda seria possível, todavia, por motivos óbvios, a parte contratante não tem interesse em receber a prestação tardiamente.

A propósito, assinala Inocêncio Galvão Telles:

Pode acontecer que, não realizando o devedor a prestação no momento devido, ela ainda continue materialmente possível mas perca interesse para o credor. A prestação, conquanto fisicamente realizável, deixou de ter oportunidade. Juridicamente não existe então simples atraso mas verdadeira inexecução definitiva. Prestação que já não interessa ao credor em consequência do atraso vale para o direito como prestação tornada impossível. ${ }^{245}$

Apesar da sua clareza no plano teórico, a dificuldade doutrinária e jurisprudencial está em definir balizas firmes de valoração de perda da utilidade da prestação diante do atraso no cumprimento da prestação, ou de não ter sido adimplida no modo ou local pactuados.

Ressalta Ruy Rosado Aguiar Júnior que “quando há impossibilidade definitiva e total da prestação, não se põe nenhuma dificuldade para o reconhecimento do incumprimento definitivo", todavia, "tratando-se das outras causas, haverá necessidade de determinar quando uma prestação ainda possível ou ainda parcialmente possível pode ser rejeitada, por caracterizar-se o incumprimento definitivo" ${ }^{\text {246. }}$.

O comentário de Ruy Rosado Aguiar Júnior, apesar de dirigido ao Código Civil de 1916, ainda é pertinente e atual no Código Civil de 2002. Continua a inexistir previsão explícita na lei brasileira quanto aos critérios que devem ser utilizados no juízo de valoração da perda da utilidade para o credor de prestação ainda possível de ser realizada pelo devedor em mora.

De maneira geral, a doutrina entende que deverá ser considerada inútil a prestação quando o atraso ou as imperfeições ofenderem substancialmente a obrigação,

\footnotetext{
245 TELLES, Inocêncio Galvão. Direito das obrigações. 4. ed. Lisboa: Coimbra Ed. 1982. p. 235.

${ }^{246}$ AGUIAR JÚNIOR, Ruy Rosado de. Extinção dos contratos por incumprimento do devedor (resolução). 2. ed. Rio de Janeiro: Aide. 1991. p. 130.
} 
provocando o desaparecimento do interesse do credor $^{247}$. A inutilidade deverá ser avaliada, portanto, "em face do tempo, do lugar e da forma do pagamento. Assim, o juiz deverá examinar se a prestação se tornou inútil ao credor, por ter sido feita com atraso, ou por não se ter realizada no lugar ou forma convencionados" 248 .

A inutilidade é considerada matéria de fato, cabendo ao juiz, diante das peculiaridades do caso concreto, verificar se a falta arguida pelo credor é de tal presença que se lhe tornou inútil, ou somente menos valiosa, hipótese em que se restará configurada a mora ${ }^{249}$. Qualquer diferença ou prejuízo decorrente do atraso do devedor autoriza o credor a demandar os danos daí decorrentes, mas não a rejeitar a prestação; para a rejeição é necessário que a prestação tenha se tornado inútil para o credor $^{250}$.

Conforme observa Agostinho Alvim, é ônus da prova do credor demonstrar que a prestação, devido à mora, não lhe apresenta mais utilidade. Não é o devedor que está sujeito a provar que a prestação continua sendo útil, mas o credor que deve comprovar a inutilidade dessa prestação. Desta feita, a "utilidade presume-se, porque, via de regra, a mora ocasiona prejuízo ao credor, mas só excepcionalmente tornará inútil a prestação" 251 ,

Frise-se que a inutilidade da prestação deve ser avaliada levando em consideração o credor da relação obrigacional concreta, e não um credor abstrato $^{252}$, o fim

\footnotetext{
${ }^{247}$ AGUIAR JÚNIOR, Ruy Rosado de. Extinção dos contratos por incumprimento do devedor (resolução). 2. ed. Rio de Janeiro: Aide. 1991. p. 132.

${ }^{248}$ ALVIM, Agostinho. Da inexecução das obrigações e suas consequências. 3. ed. atual. Rio de Janeiro: Editora Jurídica e Universitária Ltda. 1949. p. 54.

${ }^{249}$ ALVIM, Agostinho. Da inexecução das obrigações e suas consequências. 3. ed. atual. Rio de Janeiro: Editora Jurídica e Universitária Ltda. 1949. p. 54.

${ }^{250}$ ALVIM, Agostinho. Da inexecução das obrigações e suas consequências. 3. ed. atual. Rio de Janeiro: Editora Jurídica e Universitária Ltda. 1949. p. 54.

${ }^{251}$ ALVIM, Agostinho. Da inexecução das obrigações e suas consequências. 3. ed. atual. Rio de Janeiro: Editora Jurídica e Universitária Ltda. 1949. p. 57.

${ }^{252}$ A esse respeito, Agostinho Alvim pondera que: "Para traduzir o conceito de inutilidade da prestação, devemos ponderar, primeiramente, que tal inutilidade deve ser estudada em seu aspecto relativo, e não, absoluto.

Se, em virtude de atraso culposo, a prestação se torna impossível por se ter tornado imprestável a coisa objeto da mesma, haverá inutilidade para o credor e para quem quer que seja. Mas isto não é imprescindível.

O de que a lei cogita, em matéria de mora, não é da inutilidade objetiva da prestação, inutilidade para qualquer pessoa, que se confunde com o perecimento do objeto; nem do defeito ou deterioração que tenha sobrevindo à coisa, o que autoriza a enjeitá-la, com fundamento no art. 866 do Código.

Cogita-se, no art. 956, parágrafo único, da inutilidade subjetiva, inutilidade para o credor. [...]
} 
daquele negócio jurídico, bem como os limites impostos pelo princípio da boa-fé objetiva. Devem ser afastadas avaliações discricionárias acerca da permanência ou não de interesse do credor, impedindo que o credor seja movido por mero capricho. A utilidade ou inutilidade da prestação deverá ser apreciada pelo juiz à luz do interesse típico e concreto perseguido pelo credor na relação obrigacional ${ }^{253}$, verificando-se a possibilidade de consecução do resultado útil perseguido pelo credor no início da relação obrigacional.

Afirma Mário Júlio de Almeida Costa, referindo-se ao direito português:

Quanto à perda do interesse do credor na prestação, é a mesma "apreciada objectivamente" (art. $808^{\circ}, \mathrm{n}^{\circ}$ 2). Este critério significa que a importância de tal interesse, embora aferida em função da utilidade concreta que a prestação teria para o credor, não se determina de acordo com o seu juízo arbitrário, mas considerando elementos susceptíveis de valoração comum das pessoas. ${ }^{254}$

Conforme adverte Judith Martins-Costa, "o juiz deve apreender o interesse e a utilidade com base na natureza da prestação e das regras comuns de experiência (CPC, art. 335). Não há 'arbítrio' judicial (com tudo o que essa expressão ressoa de voluntarismo), mas, verdadeiramente, poder-dever de detectar, entre os elementos objetivos e os elementos subjetivos da prestação, a possível inutilidade" ${ }^{255}$.

Como a identificação da utilidade (ou inutilidade) da prestação e, consequentemente, da modalidade de inadimplemento dependem da análise de uma série de fatores objetivos e subjetivos, a cláusula geral da boa-fé objetiva assume "proeminência

$\mathrm{O}$ arbítrio do juiz entende-se com o exame da inutilidade em face do credor, sendo este, pois, um conceito relativo." ALVIM, Agostinho. Da inexecução das obrigações e suas consequências. 3. ed. atual. Rio de Janeiro: Editora Jurídica e Universitária Ltda. 1949. p. 55-56. Com a devida vênia, entendemos que o posicionamento de Agostinho Alvim deve ser lido com cautela. De fato, a utilidade da prestação deve ser apreciada levando em consideração o interesse de um credor concreto, e não de um credor abstrato. Nesse sentido, pode-se dizer que a análise deve ser feita em seu aspecto relativo (interesse do credor concreto), e não absoluto (interesse de credor abstrato). No entanto, destacamos que a apreciação da utilidade da prestação deve ser realizada tendo em vista o interesse típico e concreto perseguido pelo credor da relação obrigacional, e não o mero interesse subjetivo do credor. Daí porque entendemos que o exame da utilidade deve ser feito de maneira relativa (em relação à figura do credor) e objetiva (em relação ao interesse perseguido na relação obrigacional).

${ }^{253}$ TEPEDINO, Gustavo. BARBOZA, Heloisa Helena. MORAES, Maria Celina Bodin de. Código Civil interpretado conforme a Constituição da República. v. I. 2. ed. rev. e atual. Rio de Janeiro: Renovar. 2007. p. 718.

${ }^{254}$ ALMEIDA COSTA, Mário Júlio. Direito das obrigações. 9. ed. Coimbra: Almedina. 2001. p. 984.

${ }^{255}$ MARTINS-COSTA, Judith. Comentários ao novo Código Civil. Rio de Janeiro: Forense. 2004. p. 254. 
para a detecção do inadimplemento relativo ou do inadimplemento absoluto em face da inobservância da grade obrigacional acertada pelos contratantes" ${ }^{256}$. A função restritiva da boa-fé veda que um dos contratantes, à vista de qualquer desvio obrigacional do outro, tenha por inútil a prestação momentaneamente descumprida.

É nesse sentido que deve ser interpretado o Enunciado 162, aprovado na III Jornada de Direito Civil, promovida pelo Centro de Estudos Judiciários do Conselho de Justiça Federal, segundo o qual "a inutilidade da prestação que autoriza a recusa da prestação por parte do devedor deverá ser aferida objetivamente, consoante o princípio da boa-fé e a manutenção do sinalagma, e não de acordo com o mero interesse subjetivo do credor" 257 .

Assim, visto que "a relevância do incumprimento para efeito de resolução do contrato tem de ser apreciada em função do caso concreto, sendo o conceito de gravidade distinto segundo o tipo contratual em questão e as peculiaridades do concreto negócio estipulado" 258 , constata-se que o ponto central para a identificação da utilidade de determinada prestação está na verificação da função negocial concreta do contrato inadimplido. Ou seja, é essencial que se perquira se a prestação ainda tem o potencial de atingir a função a que inicialmente se destinava.

Acrescente-se que as partes podem convencionar que a prestação, fora do tempo ou em desacordo com o pactuado, será havida como inútil. Não se pode confundir o

\footnotetext{
${ }^{256}$ OLIVEIRA, James Eduardo de. Inadimplemento relativo e inadimplemento absoluto. In: ANDRIGHI, Fátima Nancy (Coord.). Responsabilidade civil e inadimplemento no direito brasileiro. São Paulo: Atlas. 2014. p. 19.

257 No mesmo sentido Almeida Costa disserta que: "Pode verificar-se que o atraso no cumprimento tenha feito desaparecer o interesse do credor na prestação - apreciado este segundo critério objectivo -, ou que o devedor não efectue a prestação dentro do prazo que razoavelmente for fixado por credor. Em ambas as hipóteses, a obrigação considerar-se-á, para todos os efeitos, como não cumprida." ALMEIDA COSTA, Mário Júlio de. Noções de direito civil. Coimbra: Livraria Almedina. 1980. p. 225. Gabriel Rocha Furtado também comenta que "[...] deve-se atentar para o interesse em concreto de determinado credor em específica relação contratual. Todavia, a aferição da utilidade da prestação há de ser feita com base em critérios objetivos, visualizando-se todo o programa contratual de fora, e não apenas a partir da individual subjetividade do credor - o que poderia ensejar arbitrariedades e chancelar simples caprichos -, sob pena de se sufragar e recair em vetusta orientação voluntarista. Indaga-se, em síntese, do interesse concreto do credor, objetivamente inserido na função contratual”. FURTADO, Gabriel Rocha. Mora e inadimplemento substancial. São Paulo: Atlas. 2014. p. 31.

${ }^{258}$ MARTINEZ, Pedro Romano. Da cessação do contrato. 2. ed. Coimbra: Almedina. 2006. p. 146-147.
} 
prazo fatal para o cumprimento da obrigação, ou seja, a previsão de que o não cumprimento em certo tempo, modo ou lugar, implica a inutilidade da prestação, com a regra dies interpellat pro homine, adotada pelo Código Civil ${ }^{259}$. Se o devedor não cumpre a obrigação no termo, incide em mora, exceto se o credor demonstrar que a prestação se tornou inútil. No entanto, se houver convenção expressa de que a prestação se reputa inútil se não for efetuada no tempo, modo ou local pactuados, haverá inadimplemento absoluto e não será possível purgar a mora ${ }^{260}$.

Cumpre, ainda, destacar que a impossibilidade ou a inutilidade se refere à prestação devida, e não apenas à prestação principal. Assim, se o descumprimento de um dever anexo impossibilitar ou tornar inútil a prestação para o credor, estará configurado o inadimplemento absoluto ${ }^{261}$. Exemplo paradigmático de inutilidade da prestação por violação de deveres anexos é o formulado por Clóvis do Couto e Silva, em que o comerciante contrata a fabricação e colocação de letreiro luminoso para efeitos de propaganda (divulgação do seu produto), mas a contraparte o instala em local pouco frequentado $^{262}$.

A definitividade do não cumprimento pode atingir a prestação por inteiro ou apenas parte dela. Distingue-se, então, o inadimplemento absoluto total e o inadimplemento absoluto parcial. Será total quando recobrir a totalidade dos deveres objeto da prestação devida, e parcial quando, divisível a prestação, recobrir apenas parte do que deve ser adimplido. $\mathrm{O}$ inadimplemento absoluto, seja total ou parcial, geralmente conduz à resolução do contrato, porque, em virtude do disposto no artigo 314 do Código Civil, mesmo nas obrigações divisíveis, o credor não é obrigado a receber por partes, nem o

\footnotetext{
259 “Art. 397. O inadimplemento da obrigação, positiva e líquida, no seu termo, constitui de pleno direito em mora o devedor."

${ }^{260}$ ALVIM, Agostinho. Da inexecução das obrigações e suas consequências. 3. ed. atual. Rio de Janeiro: Editora Jurídica e Universitária Ltda. 1949. p. 58.

${ }^{261}$ TERRA, Aline de Miranda Valverde. Inadimplemento anterior ao termo. Rio de Janeiro: Renovar. 2009. p. 102 .

${ }^{262}$ O exemplo é de SILVA, Clóvis do Couto e. A obrigação como processo. Rio de Janeiro: Editora FGV. 2006. p. 41.
} 
devedor a assim pagar, se tal não se ajustou, razão pela qual o inadimplemento parcial conduz, em regra, à resolução do todo ${ }^{263}$.

As consequências do inadimplemento absoluto irão variar conforme a causa do inadimplemento. Se imputável ao devedor, ocorrerá o efeito típico do inadimplemento, previsto no artigo 389 do Código Civil, que é o surgimento do dever de reparar os danos causados pelo inadimplemento. Por outro lado, se o inadimplemento for inimputável ao devedor, seja em razão de caso fortuito, de força maior, de fato de terceiro ou de fato imputável ao credor, a relação será extinta, sem que para o devedor surja a obrigação de indenizar.

\subsubsection{Inadimplemento relativo (mora): caracterização e efeitos}

No que diz respeito ao inadimplemento relativo, vale dizer que o legislador brasileiro conferiu à mora conceito amplo. Preceitua o artigo 394 do atual Código Civil brasileiro: "considera-se em mora o devedor que não efetuar o pagamento e o credor que não quiser recebê-lo no tempo, lugar e forma que a lei ou a convenção estabelecer”. No direito brasileiro, configura-se a mora não só quando há atraso no cumprimento da obrigação, mas também quando este se dá de modo imperfeito, isto é, em lugar ou forma diversa da convencionada entre as partes ou prevista na lei.

Trata-se de uma conceituação legal de mora do devedor mais ampla do que aquela feita no direito estrangeiro, que em geral restringe o conceito ao não adimplemento no tempo devido (retardamento temporal). O Código Civil português, por exemplo,

\footnotetext{
${ }^{263}$ MARTINS-COSTA, Judith. Comentários ao novo Código Civil. Rio de Janeiro: Forense, 2004. p. 149. Em sentido contrário, Ruy Rosado Aguiar Júnior afirma que: "A impossibilidade pode ser total, quando atingir toda a obrigação principal, ou meramente parcial. Afetando apenas parte da obrigação principal, dizse que há impossibilidade parcial (o caminhão de transporte perdeu parte da carga). Aplica-se a regra do art. 866 do Código Civil, criada para caso análogo da deterioração: o credor pode aceitar a prestação, com o correspondente abatimento do preço, ou enjeitá-la, optando por resolver o contrato. Para admitir a resolução, deverá o juiz verificar se houve a impossibilidade total, se a prestação parcial efetivamente já não atende ao interesse do credor, ou se a prestação possível não significa o cumprimento substancial da obrigação (a falta de um volume, na coleção rara de 10 livros, pode destruir o seu valor; já a falta de um exemplar, em partida de 10 exemplares iguais, significa que o devedor cumpriu substancialmente sua prestação, não cabendo resolver." AGUIAR JÚNIOR, Ruy Rosado de. Extinção dos contratos por incumprimento do devedor. 2. ed. Rio de Janeiro: AIDE. 1991. p.100-101.
} 
estabelece que "o devedor considera-se constituído em mora quando, por causa que lhe seja imputável, a prestação, ainda possível, não foi efetuada no tempo devido" (artigo 804, n. 2$)^{264}$.

Conforme assinala Agostinho Alvim, "é certo que mora, via de regra, manifesta-se por um retardamento, embora, em face do nosso Código, e rigorosamente falando, ela seja antes a imperfeição no cumprimento da obrigação (tempo, lugar e forma, art.955)"265. Parcela da doutrina, no entanto, critica o conceito de mora positivado pelo legislador brasileiro, afirmando que a mora continua vinculada exclusivamente ao tempo da prestação, sob a justificativa de que "a correta leitura do art. 394 do Código Civil é a de que o não pagamento ou recebimento da prestação no lugar e forma que a lei ou convenção estabelecer somente acarretará a mora se, em função da entrega em lugar diverso ou em desconformidade com a forma estabelecida, houver atraso no cumprimento da prestação" 266 .

\footnotetext{
${ }^{264}$ A respeito do conceito de mora no direito português, Almeida Costa afirma que "cabe distinguir entre o não cumprimento definitivo e o simples retardamento na prestação - a que se dá o nome de mora. Neste caso a prestação ainda poderá ser cumprida; embora já não pontualmente. Por exemplo: se $\mathrm{A}$ deve a $\mathrm{B}$ uma determinada quantia em dinheiro e não a satisfaz no prazo convencionado, o pagamento será todavia possível depois dessa data, visto que o credor continua a ter interesse em recebê-lo". ALMEIDA COSTA, Mário Júlio de. Noções de direito civil. Coimbra: Livraria Almedina. 1980. p. 219-220. Sobre o conceito de mora no direito espanhol, Luis Diez-Picazo e Antonio Gullon afirmam que "según el artículo 1.100 del Código civil, 'incurren en mora los obligados a dar o hacer alguna cosa desde que el acreedor les exija judicial o extrajudicialmente el cumplimiento de la obligación'. Para tanto, hay que conectar la mora con la idea de tiempo en que la prestación ha de cumplirse. Si llegado el mismo el deudor no cumple, no hay duda de que infringe, por ese mero retardo, su deber jurídico, pero no surge la mora. Mora y retardo son conceptos que no coinciden automáticamente, y por eso se ha dicho que la mora es un retardo cualificado". DIEZ-PICAZO, Luis; GULLON, Antonio. Sistema de derecho civil. v. II. Madrid: Editorial Tecnos. 1978. p. 155.

Em tradução livre: "nos termos do artigo 1.100 do Código Civil, 'incorre em mora o obrigado a dar ou fazer alguma coisa desde que o credor exija judicial ou extrajudicialmente o cumprimento da obrigação'. Para tanto, é preciso relacionar a mora com a ideia do tempo em que a obrigação deve ser cumprida. Se ele for atingido sem que o devedor adimpla, não há dúvida de que ele infringe, com esse atraso, o seu devedor jurídico, mas não surge a mora. Mora e atraso são conceitos que não coincidem necessariamente, e por isso se diz que a mora é um atraso qualificado."

${ }^{265}$ ALVIM, Agostinho. Da inexecução das obrigações e suas consequências. 3. ed. atual. Rio de Janeiro: Editora Jurídica e Universitária Ltda. 1949. p. 18.

${ }^{266}$ SAVI, Sérgio. Inadimplemento das Obrigações, Mora e Perdas e Danos. In: TEPEDINO, Gustavo (Coord.). Obrigações: estudos na perspectiva civil-constitucional. Rio de Janeiro: Renovar. 2005. p. 467. No mesmo sentido: TEPEDINO, Gustavo; BARBOZA, Heloisa Helena; MORAES, Maria Celina Bodin de. Código Civil interpretado conforme a Constituição da República. v. I, 2. ed. rev. e atual. Rio de Janeiro: Renovar. 2007. p. 709. Confira-se, a respeito, o posicionamento de Jorge Cesa Ferreira da Silva: "Todas as principais legislações da família Romano-Germânica restringem a mora ao 'atraso' no prestar ou no receber a prestação. No Brasil, incluindo ela além do tempo, o lugar e a forma da prestação - mesmo que esses fatores, como se defendeu sejam apenas modo de realizar-se o 'atraso', este sim verdadeiro elemento central do
} 
Em que pese essa respeitável posição doutrinária de que, mesmo a prestação em forma ou local diverso implica sempre em retardo da prestação, parece-nos relevante a opção do legislador brasileiro, que expressamente alargou o conceito de mora e enfatizou que não é apenas o retardo que está no núcleo conceitual de mora.

Diz-se que há mora quando a obrigação não foi cumprida no tempo, lugar e forma convencionados ou estabelecidos pela lei, mas ainda poderá sê-lo, com proveito para o credor. Ainda interessa ao credor receber a prestação acrescida dos juros, atualização dos valores monetários, cláusula penal, etc. (artigos 394 e 395 do Código Civil). No entanto, se a prestação, por causa do retardamento ou do imperfeito cumprimento, se tornar inútil ao credor, estará caracterizado o inadimplemento absoluto ${ }^{267}$.

É esse o posicionamento de Agostinho Alvim sobre o tema:

Como se vê, a unanimidade dos escritores distingue a mora do inadimplemento absoluto, apontando, como característica da primeira a possibilidade de ainda ser cumprida a obrigação, e do segundo, a impossibilidade em que fica o devedor de executá-la.

Acompanhando a doutrina dominante, nós entendemos que o critério para a distinção reside, efetivamente, na possibilidade ou impossibilidade, mas essa possibilidade ou impossibilidade, com maior precisão, não há de se referir ao devedor, e sim ao credor; possibilidade ou não de receber a prestação, o que é diferente. $^{268}$

O conceito de mora não deriva exclusivamente do artigo 394 do Código Civil, devendo ser complementado pelo disposto no artigo 396, do mesmo código, que exige, para a caracterização da mora, que o adimplemento lhe seja imputável. A falta de execução da obrigação no tempo, forma e local de execução devidos poderá acarretar a mora do devedor ou do credor, dependendo do caso concreto. Incumbirá àquele a quem for imputada a responsabilidade pelos prejuízos decorrentes da mora o ônus de provar a

conceito - a tendência interpretativa é concebê-la como a via residual do inadimplemento". SILVA, Jorge Cesa Ferreira da. A boa-fé e a violação positiva do contrato. Rio de Janeiro: Renovar. 2002. p. 208-209.

${ }^{267}$ GONÇALVES, Carlos Roberto. Direito civil brasileiro. v. 2: Teoria geral das obrigações. 8. ed. São Paulo: Saraiva. 2011. p. 379. No mesmo sentido: MARTINS-COSTA, Judith. Comentários ao novo Código Civil. Rio de Janeiro: Forense. 2004. p. 148.

${ }^{268}$ ALVIM, Agostinho. Da inexecução das obrigações e suas consequências. 3. ed. atual. Rio de Janeiro: Editora Jurídica e Universitária Ltda. 1949. p. 45. 
existência de um fato capaz de afastar a sua imputabilidade, como, por exemplo, a ocorrência de caso fortuito ou força maior.

Questão interessante é a do "caráter transformista" da mora ${ }^{269}$. Há situações em que, apesar de a prestação estar em atraso por motivo imputável ao devedor e de ainda ser possível o seu cumprimento tardio, a mora se converte supervenientemente em inadimplemento absoluto em virtude da falta de interesse do credor em receber a prestação tardiamente (artigo 395, parágrafo único, do Código Civil). A esse respeito, Gabriel Rocha Furtado comenta que:

\begin{abstract}
A mora, acima definida como uma zona de interseção fluida entre o adimplemento e o inadimplemento absoluto, tem como uma de suas características marcantes a possibilidade de vir a acarretar a extinção da relação contratual no caso de a prestação, por sua causa, tornar-se sem utilidade ao credor. Nesse cenário, reconhece-se o definitivo incumprimento da obrigação e, por isso, o inadimplemento absoluto. Reside nisto o chamado "caráter transformista da mora". ${ }^{270}$
\end{abstract}

Acrescente-se que o Código Civil brasileiro contempla expressamente as hipóteses de mora do devedor e de mora do credor $^{271}$. O conceito de mora do devedor (ou mora solvendi) pode ser extraído da conjugação dos artigos 394 e 395 do Código Civil. A mora solvendi será o não cumprimento, pelo devedor, da obrigação no tempo, modo ou local pactuado, por fato a ele imputável. Portanto, são requisitos da mora do devedor: (i) a imputabilidade; (ii) a exigibilidade imediata da obrigação e (iii) interpelação nos casos das obrigações sem prazo estipulado para o adimplemento.

De acordo com o disposto no artigo 395 do Código Civil, o principal efeito da mora do devedor consiste na sua responsabilização pelos prejuízos que o credor vier a sofrer em razão do não cumprimento, pelo devedor, da obrigação no tempo, modo ou local pactuado, por fato a ele imputável ${ }^{272}$. No caso de mora do devedor, a indenização, ao

\footnotetext{
269 A expressão é de ASSIS, Araken de. Resolução do contrato por inadimplemento, 4. ed. São Paulo: Revista dos Tribunais. 2004. p. 110.

${ }^{270}$ FURTADO, Gabriel Rocha. Mora e Inadimplemento Substancial. São Paulo: Atlas. 2014. p. 89.

${ }^{271} \mathrm{O}$ tema da mora do credor será tratado em item adiante.

${ }^{272}$ Agostinho Alvim afirma que "o efeito principal da mora é tornar o devedor responsável pelos prejuízos que dela se originarem". ALVIM, Agostinho. Da inexecução das obrigações e suas consequências. 3. ed. atual. Rio de Janeiro: Editora Jurídica e Universitária Ltda. 1949. p. 53.
} 
contrário do que ocorre nas hipóteses de inadimplemento absoluto, não tem o condão de substituir a prestação devida. Isso porque, se a prestação ainda for útil para o credor, ele poderá exigir a execução da prestação, cumulada com a indenização pelos prejuízos causados pela mora do devedor ${ }^{273}$.

Confiram-se os ensinamentos de Pontes de Miranda sobre a questão:

há nos contratos bilaterais, a) a pretensão à prestação devida mais a pretensão às perdas e danos pela mora (art. 956); b) a pretensão à indenização total (falta de prestação mais perdas e danos pela mora), que o credor, se não tem interêsse na prestação (art. 956, parágrafo único, verbis "se tornar inútil ao credor"), pode preferir, ou, sempre, pôr em alternativa a favor do devedor; c) exercível a seu libito, a pretensão à resolução do contrato bilateral (art. 1.092, parágrafo único). ${ }^{274}$

O segundo efeito da mora do devedor decorre da interpretação do parágrafo único do artigo 395 do Código Civil. De acordo com o referido dispositivo legal, se em virtude da mora, a prestação se tornar inútil ao credor, este poderá enjeitá-la e exigir indenização pelos danos sofridos com a mora. Assim, surge uma alternativa para o credor, que poderá aceitar a prestação acrescida da indenização pelos prejuízos sofridos ou, se provar que a prestação se tornou inútil por causa da mora, poderá rejeitá-la e reclamar perdas e danos. Nos bilaterais, se o credor provar a inutilidade da prestação tardiamente prestada - e a ele é atribuído esse ônus -, poderá pedir a resolução do contrato ${ }^{275}$.

O terceiro efeito da mora do devedor está previsto na primeira parte do artigo 399 do Código Civil, que consagra a perpetuação da obrigação do devedor moroso. Conforme se extraí do artigo 393 do Código Civil, o caso fortuito e a força maior resolvem a obrigação. Contudo, de acordo com o artigo 399 do Código Civil, o devedor, uma vez em mora, passa a responder pelos riscos da coisa, inclusive por aqueles riscos decorrentes de caso fortuito e de força maior. Conforme afirma Almeida Costa, "o devedor moroso torna-

\footnotetext{
273 SAVI, Sérgio. Inadimplemento das Obrigações, Mora e Perdas e Danos. In: TEPEDINO, Gustavo (Coord.). Obrigações: estudos na perspectiva civil-constitucional. Rio de Janeiro: Renovar. 2005. p. 468.

${ }^{274}$ PONTES DE MIRANDA, Francisco Cavalcanti. Tratado de direito privado. tomo XXIII. São Paulo: Editora Revista dos Tribunais. p. 261-262.

${ }^{275}$ RODRIGUES, Silvio. Direito civil. v. 2. 30. ed. São Paulo: Saraiva. 2002. p. 247.
} 
se responsável pelo risco da deterioração ou perda da coisa devida, mesmo que esses factos não lhe sejam imputáveis. É a chamada perpetuação da obrigação"276.

A regra da perpetuação da obrigação sofre, todavia, um abrandamento, tendo o Código Civil previsto duas hipóteses em que, não obstante a mora, o devedor não responderá pelos riscos do fortuito e da força maior. A primeira exceção ocorrerá quando o devedor conseguir provar que os danos sobreviriam mesmo que a obrigação fosse oportunamente desempenhada. Como exemplo desta hipótese, pode-se mencionar o de uma casa que é destruída por um raio na pendência da mora do devedor. Ainda que o devedor tivesse cumprido a sua obrigação no tempo devido, o credor perderia a casa em virtude do raio que a destruiu ${ }^{277}$.

O artigo 399 do Código Civil estabelece uma segunda exceção à regra da perpetuação da obrigação, ao prever que o devedor não responderá pelos prejuízos causados pelo caso fortuito durante a sua mora "se provar a isenção de culpa". A leitura desta parte do dispositivo legal poderá ser feita de duas maneiras, dependendo do conceito de imputabilidade utilizado pelo intérprete.

Para aqueles que consideram a culpa (em sentido amplo) um requisito essencial da imputabilidade e, portanto, também, da mora, a exceção prevista nesta parte do dispositivo seria inútil, supérflua. Para esta corrente doutrinária, dizer que o devedor responde pela mora, salvo se provar ausência de culpa, equivale a dizer que ele responde por mora, salvo se não houver mora ${ }^{278}$.

\footnotetext{
${ }^{276}$ ALMEIDA COSTA, Mário Júlio de. Noções de direito civil. Coimbra: Livraria Almedina. 1980. p. 225.

${ }^{277}$ PEREIRA, Caio Mário da Silva. Instituições de Direito Civil. vol. II. 20. ed. Rio de Janeiro: Forense, 2005. p. 311.

${ }^{278}$ Nesse sentido pondera Agostinho Alvim: "A primeira dessas exceções é ociosa, e, mais do que isso, revela defeito de técnica (ver supra $\mathrm{n}^{\circ} 16$ ).

Realmente, provada a ausência de culpa, deixa de haver mora, por falta do seu elemento subjetivo e consoante disposto no art. 963.

Dizer que o devedor responde por mora, salvo se provar ausência de culpa, equivale a dizer que ele responde pela mora, salvo se houver mora." ALVIM, Agostinho. Da inexecução das obrigações e suas consequências. 3. ed. atual. Rio de Janeiro: Editora Jurídica e Universitária Ltda. 1949. p. 60.
} 
De outro lado, para aqueles que não consideram a culpa um requisito essencial da imputabilidade, e, consequentemente, da mora, e que admitem a divisão da imputabilidade em subjetiva (com fundamento na culpa em sentido amplo) e objetiva, a exceção prevista nesta frase do artigo 399 do Código Civil tem o seguinte significado: mesmo que a prestação estiver atrasada o devedor poderá alegar a excludente de caso fortuito e força maior se provar, e a ele caberá esse ônus, que a mora não lhe pode ser imputável porque não foi gerada por sua culpa ${ }^{279}$.

Conforme exposto no item acima, nos filiamos à segunda corrente, razão pela qual entendemos que a exceção prevista nesta frase do artigo 399 do Código Civil consiste na prova produzida pelo devedor de que inexistiu culpa de sua parte no atraso da prestação. Como a exceção visa a beneficiar o devedor, a demonstração da inexistência de culpa passa a ser um ônus imposto ao devedor em mora ${ }^{280}$.

Por fim, vale mencionar que o artigo 401 do Código Civil estabelece os requisitos para a purga (emenda) da mora pelo devedor, que é o procedimento espontâneo do contratante moroso, pelo qual se prontifica a remediar a situação a que deu causa, sujeitando-se aos efeitos dela decorrentes ${ }^{281}$. A mora pode ser purgada, desde que a prestação continue sendo útil ao credor e que as partes não tenham previamente estipulado que a ocorrência de mora implicaria na resolução imediata do negócio jurídico. Nos termos do inciso I do artigo 401, do Código Civil, para que o devedor purgue a mora, deverá oferecer a prestação no lugar e forma convencionados, acrescida de importância relativa a todos os prejuízos sofridos pelo credor em função de sua mora ${ }^{282}$.

\footnotetext{
${ }^{279}$ SAVI, Sérgio. Inadimplemento das Obrigações, Mora e Perdas e Danos. In: TEPEDINO, Gustavo (Coord.). Obrigações: estudos na perspectiva civil-constitucional. Rio de Janeiro: Renovar. 2005. p. 471. ${ }^{280}$ MARTINS-COSTA, Judith. Comentários ao novo Código Civil. Rio de Janeiro: Forense. 2004. p. 299. ${ }^{281}$ SAVI, Sérgio. Inadimplemento das Obrigações, Mora e Perdas e Danos. In: TEPEDINO, Gustavo (Coord.). Obrigações: estudos na perspectiva civil-constitucional. Rio de Janeiro: Renovar, 2005. p. 474-475. ${ }^{282}$ A esse respeito, Almeida Costa leciona que: "[...] a extinção da mora debitória recebe o nome de purgação ou emenda da mora. Verifica-se, em regra, pela satisfação do credor, mediante o cumprimento da prestação devida e de tudo o mais a que ele tenha direito em consequência do cumprimento tardio. O devedor deixará também de estar constituído em mora quando o credor renuncie aos efeitos desta. E ocorre mesmo uma inversão da mora - todavia, sem prejuízo das consequências já produzidas -, a partir do momento em que o credor recuse, ilegitimamente, a oferta da prestação debitória, acrescida do resto que lhe seja devido em razão do atraso no cumprimento.” ALMEIDA COSTA, Mário Júlio de. Noções de direito civil. Coimbra: Livraria Almedina. 1980. p. 225-226.
} 
Expostas as principais características e efeitos do inadimplemento absoluto e relativo, passar-se-á ao exame do tema da "violação positiva do contrato", essencial à posterior análise do inadimplemento antecipado.

\subsubsection{Da desnecessidade da "violação positiva do contrato" como uma terceira modalidade de inadimplemento no direito brasileiro}

Inúmeras têm sido as críticas feitas contra a teoria dicotômica acerca do inadimplemento (inadimplemento absoluto e mora). Em um dos estudos mais importantes sobre o tema, Hermann Staub elaborou, em 1902, a teoria da violação positiva do crédito $^{283}$, a partir da constatação de lacunas no regramento do inadimplemento no $\mathrm{BGB}^{284}$. Para o referido autor, para além do inadimplemento absoluto e da mora (que na redação do BGB vigente à época se restringia ao atraso no cumprimento da prestação), existiriam outras hipóteses não reguladas, apesar de igualmente configurarem inadimplemento. Para ele, tanto o inadimplemento absoluto quanto a mora correspondiam a violações negativas do crédito: no primeiro, a prestação não é realizada, enquanto no segundo a prestação não é realizada no momento adequado.

Hermann Staub verificou que em diversos casos o dano sofrido pelo credor não resultaria de omissão ou atraso no cumprimento, mas de ação positiva, de vícios ou deficiências da prestação, que não se realizou da forma pactuada pelas partes ou da forma legitimamente esperada pelo credor. As hipóteses por ele elencadas acarretariam inadimplemento em casos em que a prestação foi realizada, mas de maneira inexata (cumprimento inexato). Para diferenciar esses casos dos anteriores, Hermann Staub decidiu chamar essas hipóteses de violações positivas do contrato ${ }^{285}$.

Nesse sentido o seguinte trecho da obra de Hermann Staub:

\footnotetext{
${ }^{283}$ De acordo com Marcos Jorge Catalan, a teoria da violação positiva do crédito tem ampla sinonímia, dentre as quais: cumprimento defeituoso; adimplemento ruim; inexecução contratual positiva; violação positiva do crédito; violação contratual positiva e lesión del deber. CATALAN, Marcos Jorge. Descumprimento contratual. Curitiba: Juruá. 2005. p. 161.

${ }^{284}$ STAUB, Hermann. Le violazioni positive del contrato. Trad. de Giovanni Varanese. Napoli: ESI. 2001.

285 SILVA, Jorge Cesa Ferreira da. Inadimplemento das obrigações. São Paulo: Editora Revista dos Tribunais. 2007. p. 43.
} 
Il BGB non contiene, peraltro, un'analoga disposizione per le numerose ipotesi in cui qualcuno viola un'obbligazione mediante condotta positiva, facendo qualcosa che dovrebbe omettere, oppure eseguendo la prestazione dovuta, ma in modo inesatto. ${ }^{286}$

Entre os vários exemplos mencionados por Hermann Staub encontra-se o da cervejaria que, contratada para fornecer cerveja a uma estalagem em bases contínuas, o faz regularmente e nos dias combinados, mas, em algumas oportunidades, fornece cerveja da pior qualidade, o que acarreta na perda de clientela pela estalagem. No caso, Hermann Staub analisa que não teria havido inadimplemento absoluto ou mora, visto que o interesse da estalagem permanecia, a prestação era possível e foi realizada no momento adequado. Também não teria ocorrido mora porque o conceito de mora no BGB se restringia ao atraso culposo da prestação ${ }^{287}$. Esse é um dos exemplos de aplicação da teoria da violação positiva do crédito formulada pelo jurista alemão ${ }^{288}$.

As hipóteses fáticas abrangidas pela violação positiva do crédito não guardam unicidade interna. Isso se deve ao fato de a teoria ter sido elaborada a partir de situações práticas que, apesar de diversas entre si, caracterizavam-se todas pelo fato de não serem

\footnotetext{
${ }^{286}$ STAUB, Hermann. Le violazioni positive del contrato. Tradução de Giovanni Varanese. Napoli: ESI. 2001. p. 39. Em tradução livre: "O BGB não contém, por outro lado, uma análoga disposição para as numerosas hipóteses em que alguém viola uma obrigação mediante conduta positiva, fazendo alguma coisa que deveria omitir, ou executando a prestação devida, mas de maneira inexata."

${ }^{287}$ SILVA, Jorge Cesa Ferreira da. Inadimplemento das obrigações. São Paulo: Editora Revista dos Tribunais. 2007. p. 43.

${ }^{288} \mathrm{~J}$. W. Hedemann também menciona os seguintes exemplos de violação positiva do contrato: "1. Un fabricante entrega a un comerciante sus productos en exclusiva, es decir, con la promesa solemne de que no entregará el mismo producto a ningún otro comerciante del mismo distrito (promesa de monopolio). Después falta a su obligación y entrega el producto a un segundo comerciante, por tanto, a un competidor del primero, y así con este acto positivo hizo lo que debió omitir. 2. A un huésped le son servidos alimentos echados a perder (además de infracción contractual, en esto caso puede concurrir un 'acto ilícito'). 3. Un empleado revela secretos del negocio; quizá existía sobre ello prohibición en el contrato, pero también sin pacto expreso, frecuentemente se deducirá la prohibición de comunicar dichos secretos del conjunto de la situación contractual. Esta deslealtad implica también un acto positivo." HEDEMANN, J.W. Derecho de Obligaciones. v. III. Trad. de Jaime Santos Briz. Editorial Revista de Derecho Privado: Madrid, 1958. p. 185. Em tradução livre: "1. Um fabricante oferece a um distribuidor um de seus produtos em caráter de exclusividade, ou seja, com a promessa solene que não vai entregar o mesmo produto para qualquer outro operador no mesmo território (promessa de monopólio). Depois descumpre a sua obrigação e entrega o produto para um segundo comerciante, portanto, um concorrente do primeiro, e, assim, fez com este ato positivo o que deveria ter se omitido de fazer. 2. A um hóspede são servidos alimentos com prazo de validade vencido (além de inadimplemento contratual, neste caso, pode concorrer um ' delito'). 3. Um funcionário revela segredos do negócio; talvez esta proibição exista no contrato, mas mesmo sem acordo expresso, frequentemente se deduzirá a proibição de comunicar os segredos do conjunto do contrato. Esta deslealdade também implica um ato positivo."
} 
passíveis de configuração de mora ou inadimplemento absoluto no direito alemão vigente à época $^{289}$.

Dentre as hipóteses abarcadas pela violação positiva do crédito estão: a violação de deveres de omissão; o desrespeito aos deveres de cuidado e de proteção; a ofensa a deveres laterais como os de informação, conselho e segredo; a situação ocorrida em um contrato de fornecimento sucessivo, quando é desrespeitado apenas um dever de entrega; a hipótese em que o devedor declara, categoricamente, que não irá cumprir a obrigação; os casos de responsabilidade pós-contratual e os casos de cumprimento defeituoso $^{290}$.

Segundo Hermann Staub, o fundamento para a obrigação de ressarcimento do dano causado nessas hipóteses estaria em um princípio geral existente no BGB, segundo o qual a consequência jurídica da violação de uma obrigação com culpa consiste no dever de reparar o dano, exceto se essa consequência for excluída por lei ${ }^{291}$.

No entanto, vale ressaltar que a principal relevância da teoria da violação positiva do crédito não está na identificação do seu fundamento, mas na identificação dos seus efeitos. A partir da aplicação dessa teoria tornou-se possível aplicar àqueles casos,

\footnotetext{
${ }^{289}$ Confiram-se as lições de J. W. Hedemann a esse respeito: "Las llamadas violaciones positivas del crédito. - Se ha indicado que se trata en este caso de una construcción doctrinal. Sus características resultan de su misma denominación: en los tres supuestos clásicos aceptados por la doctrina pandectista se trata de algo negativo: el deudor omite lo que debía haber hecho (incumple totalmente, o no cumple puntualmente o lo hace defectuosamente). En cambio, ahora se trata de una vulneración activa: el deudor hace algo que debía ter omitido. Más ampliamente sobre ello $§ 22$.

La necesidad de añadir esta cuarta categoría es consecuencia de que en B.G.B falte una fórmula general que recoja la responsabilidad por contravenciones positivas del deudor." HEDEMANN, J.W. Derecho de obligaciones. v. III. Trad. de Jaime Santos Briz. Madrid: Editorial Revista de Derecho Privado. 1958. p. 157). Em tradução livre: "As chamadas violações positivas de crédito. - Se afirmou que se trata de uma construção doutrinária. Suas características resultam do seu nome: as três premissas clássicas aceitas pela doutrina pandectista são algo negativo: o devedor omite o que eu deveria ter feito (descumprir completamente, ou não cumprir pontualmente ou fazer de maneira defeituosa). Todavia, aqui se trata de uma violação ativa: o devedor faz algo que deveria ter omitido. De forma mais ampla sobre isso o $\S 22$.

A necessidade de adicionar esta quarta categoria é o resultado de que no BGB falta uma fórmula geral que reconheça a responsabilidade por infrações positivas do devedor."

${ }^{290}$ CATALAN, Marcos Jorge. Reflexões sobre o inadimplemento inexato da obrigação no direito contratual. In: HIRONAKA, Giselda Maria Fernandes Novaes; TARTUCE, Flávio (Coord.). Direito contratual. Temas Atuais. São Paulo: Método. 2007. p. 343.

${ }^{291}$ STAUB, Hermann. Le violazioni positive del contrato. Trad. de Giovanni Varanese. Napoli: ESI. 2001. p. 40.
} 
além do dever de indenizar, todos os outros efeitos do inadimplemento, como a possibilidade de recusar a prestação mal efetuada, bem como de resolver o contrato ${ }^{292}$.

A esse respeito, J. W. Hedemann afirma que "las consecuencias de la violación positiva del crédito se reglamentan del mejor modo, como ya se ha dicho, adaptando las disposiciones sobre la imposibilidad y la mora" e que, por conseguinte, o credor poderia optar entre um pedido de indenização pelos danos decorrentes do inadimplemento e a resolução do contrato ${ }^{293}$.

Apesar das críticas, a teoria de Hermann Staub foi acolhida pela jurisprudência alemã, sobretudo pela sua flexibilidade, que permitia usá-la de modo residual, abarcando toda e qualquer circunstância de inadimplemento não contemplada pelos dispositivos referentes aos conceitos de inadimplemento absoluto e mora do $\mathrm{BGB}^{294}$.

Em $1^{\circ}$ de janeiro de 2002, entrou em vigor uma das mais profundas reformas do BGB, que remodelou grande parte do capítulo relativo ao direito das obrigações ${ }^{295}$. Algumas construções doutrinárias desenvolvidas ao longo do último século foram incorporadas ao BGB, entre as quais se destaca a teoria da violação positiva do contrato. Com efeito, recentemente introduziu-se na lei alemã uma cláusula geral ${ }^{296}$ destinada a reger todas as reclamações de indenização por violação de dever relacionado à relação

\footnotetext{
292 SILVA, Jorge Cesa Ferreira da. A boa-fé e a violação positiva do contrato. Rio de Janeiro: Renovar. 2007. p. 224-225.

${ }^{293}$ HEDEMANN, J.W. Derecho de obligaciones. v. III. Trad. de Jaime Santos Briz. Madrid: Editorial Revista de Derecho Privado. 1958. p. 186.

294 SILVA, Jorge Cesa Ferreira da. Inadimplemento das obrigações. São Paulo: Editora Revista dos Tribunais. 2007. p 41-42. Nesse mesmo sentido: HEDEMANN, J.W. Derecho de obligaciones. v. III. Trad. de Jaime Santos Briz. Madrid: Editorial Revista de Derecho Privado. 1958. p. 184-185.

${ }^{295}$ CORDEIRO, Menezes António. Tratado de direito civil português. v. II. Direito das obrigações. tomo I. Coimbra: Almedina. 2009. p. 71.

${ }^{296}$ Conforme se observa do $\S 280$, I, do BGB: "if the debtor fails to comply with a duty arising under the contract, the creditor is entitled to claim compensation for the loss caused by such breach of his duty. This does not apply if the debtor is not responsible for the breach of duty". Em tradução livre: "se o credor não cumprir uma obrigação contratual, o credor terá direito de reivindicar indenização por perdas e danos causadas por tal descumprimento. Isso não se aplica caso o devedor não seja responsável pelo descumprimento da obrigação.” A tradução para o inglês do BGB pode ser acessada no site: <http://www.gesetze-im-internet.de/englisch_bgb/>. Acesso em: 15 out. 2013.
} 
obrigacional, seja de dever imposto por lei, seja de dever estabelecido pelas partes, abrangendo, portanto, a figura da violação positiva do contrato ${ }^{297}$.

Antes da reforma do BGB, a violação positiva do contrato - que até então era uma construção doutrinária e jurisprudencial - "constituía um tertium genus no universo do incumprimento em sentido lato, ao lado da impossibilidade imputável ao devedor e da pura e simples omissão da prestação devida" ${ }^{\text {298 }}$. Todavia, com a reforma do BGB ocorrida em 2001/2002, resolveu-se o problema da violação positiva do contrato ao se estabelecer que o inadimplemento restará caracterizado com o descumprimento de qualquer dever proveniente de uma relação obrigacional, inclusive deveres decorrentes da boa-fé objetiva.

Confiram-se, abaixo, os ensinamentos de António Menezes de Cordeiro sobre a modernização do BGB e a positivação da figura da violação positiva do contrato no direito alemão:

\begin{abstract}
A doutrina fora obrigada a construir a categoria da violação positiva do contrato, perante o silêncio da lei. Apesar de uma jurisprudência muito rica que, ao longo do século XX, foi preenchendo os diversos meandros em aberto, as dúvidas eram inevitáveis.

A reforma do BGB de 2001/2002 cobriu o problema da violação positiva do contrato, ainda que sem o nomear. Assim:

- o $\$ 280 / 281$ comete ao devedor que viole um dever proveniente de uma relação obrigacional (qualquer que seja) o dever de indenizar;

- o $\$ 324$ permite, perante a violação de um dever proveniente de relação obrigacional (e seja, ele, também, qualquer um) a resolução do contrato pelo credor. $^{299}$
\end{abstract}

A teoria da violação positiva do crédito também encontrou acolhida ou, no mínimo, análise no campo do direito estrangeiro ${ }^{300}$. De acordo com Jorge Cesa Ferreira da

\footnotetext{
${ }^{297}$ Jorge Cesa Ferreira da Silva entende que a inclusão no BGB da referida cláusula geral de indenização não retirou a utilidade da teoria da violação positiva do crédito, sob a justificativa de que "os problemas trazidos pela doutrina não se extinguiram com a reforma, mas ao contrário, nela reafirmaram a sua importância, como comprova a expressa previsão legal dos deveres laterais como decorrentes da relação obrigacional”. SILVA, Jorge Cesa Ferreira da. Inadimplemento das obrigações. São Paulo: Editora Revista dos Tribunais. 2007. p 48.

${ }^{298}$ CORDEIRO, Menezes António. Tratado de direito civil português. v. II. Direito das obrigações. tomo I. Coimbra: Almedina. 2009. p. 84.

${ }^{299}$ CORDEIRO, Menezes António. Tratado de direito civil português. v. II. Direito das obrigações. tomo I. Coimbra: Almedina. 2009. p. 85.

${ }^{300}$ Almeida Costa afirma que a doutrina portuguesa reconheceu a figura da violação positiva do contrato: "Às duas formas de não cumprimento a que já nos referimos - impossibilidade definitiva e mora - veio à doutrina
} 
Silva, vários são os ordenamentos jurídicos ou doutrinadores estrangeiros que acolhem a aplicação de uma terceira hipótese de inadimplemento, muitas vezes chamada de adimplemento ruim ou cumprimento defeituoso. Segundo o referido autor, "assim como se entendeu na Alemanha, a hipótese abrangeria todos os casos de inadimplemento não agrupáveis entre as demais figuras" ${ }^{\prime 301}$.

No direito brasileiro, os autores que abordam o assunto aplicam a teoria da violação positiva do crédito com temperamentos ${ }^{302}$ e lhe conferem maior ou menor abrangência conforme a interpretação que dão ao conceito de mora ${ }^{303}$. Todas as orientações, todavia, afastam-se da noção de mora mais ampla, anteriormente referida.

Orlando Gomes, por exemplo, adota conceito bastante restrito de mora, sustentando que o termo mora somente deve ser utilizado para se referir ao atraso no cumprimento da prestação, in verbis:

\begin{abstract}
Mora se há de definir, pois, como impontualidade culposa. Verifica-se quando o devedor não efetua o pagamento no devido tempo por fato, ou omissão, que lhe seja imputável.
\end{abstract}

$[\ldots]$

moderna acrescentar a de cumprimento imperfeito. Incluem-se nesta modalidade várias hipóteses de ofensa do direito do credor que não cabem nas outras; isto é, em que se verifica uma violação do crédito, apesar de o devedor não se encontrar em mora, nem haver impossibilidade definitiva. Será o caso, por exemplo, de o devedor efectuar uma prestação defeituosa. Assim: numa venda de gado, o vendedor entrega reses doentes que vão contagiar os restantes animais que o comprador tem nos seus estábulos.” ALMEIDA COSTA, Mário Júlio de. Noções de direito civil. Coimbra: Livraria Almedina. 1980. p. 220. Luis Diez-Picazo e Antonio Gullon comentam que no direito espanhol "puede decirse que hay cumplimiento inexacto en el caso de que la prestación efectuada no posea los requisitos subjetivos y objetivos que son idóneos para hacerla coincidir con el objeto de la obligación, y para satisfacer el interés del acreedor". DIEZ-PICAZO, Luis e GULLON, Antonio. Sistema de derecho civil. v. II. Madrid: Editorial Tecnos. 1978. p. 164. Em tradução livre: "pode-se dizer que há cumprimento inexato na situação em que a prestação entregue não possui os requisitos subjetivos e objetivos que são necessários para fazê-la coincidir com o objeto da obrigação e para satisfazer o interesse do credor."

${ }^{301}$ SILVA, Jorge Cesa Ferreira da. Inadimplemento das obrigações. São Paulo: Editora Revista dos Tribunais. 2007. p. 44.

${ }^{302}$ Nesse sentido, Jorge Cesa Ferreira da Silva assevera que “[...] as diferenças entre os ordenamentos brasileiro e alemão, faz com que o modelo conceitual da violação positiva do contrato não possa ser simplesmente traduzido literalmente para o Brasil. Cumpre desvendar os espaços que poderiam ser por ele ocupados e aqueles que já estariam suficientemente regulados, tendo por ponto de partida o conceito alemão". SILVA, Jorge Cesa Ferreira da. A boa-fé e a violação positiva do contrato. Rio de Janeiro: Renovar. 2002. p 214-215.

${ }^{303}$ TERRA, Aline de Miranda Valverde. Inadimplemento anterior ao termo. Rio de Janeiro: Renovar. 2009. p. 110 . 
Elemento Objetivo da mora é o retardamento. Trata-se de conceito que se prende à ideia de tempo. Mora pressupõe crédito vencido, certo e judicialmente exigível. Entretanto, pretende-se que também ocorre quando o devedor não paga no lugar devido ou pela forma convencionada. Essa extensão conceitual foi acolhida na lei pátria. O legislador não merece aplauso pelo abandono do conceito tradicional. $\mathrm{O}$ próprio nome atesta que se refere a retardamento. Mora é demora, atraso, impontualidade, violação do dever de cumprir a obrigação no tempo devido. Pelas infrações relativas ao lugar e à forma do pagamento também responde o devedor, mas, tecnicamente, não configuram mora. Deve-se reservar o vocábulo para designar unicamente o atraso, contrário ao direito na efetivação do pagamento. ${ }^{304}$

Ao adotar conceito restritivo de mora, Orlando Gomes acaba por conferir à violação positiva do crédito maior abrangência, afirmando que se está diante da figura do cumprimento defeituoso nas situações em que o devedor não efetua o pagamento no lugar e forma convencionados. O referido autor entende que mora e cumprimento defeituoso são institutos diferentes aos quais se aplicam, por analogia, a mesma solução jurídica.

Nesse sentido, confira-se o seguinte trecho da obra de Orlando Gomes:

O conceito de violação positiva do crédito, conforme crítica de Enneccerus, está mal delimitado em relação à impossibilidade e à mora, porque a infração contratual positiva desloca para segundo plano o ato que determina o dano, enquanto a mora e a impossibilidade representam situações jurídicas nas quais pode desembocar qualquer violação de crédito, tanto de natureza negativa como positiva. Entendido, porém, como cumprimento defeituoso, no sentido que Zitelmann empresta à locução, serve para qualificar as situações nas quais o devedor não efetua o pagamento no lugar e forma convencionados. Cumpre mal a obrigação quem não observa estipulação contratual ou determinação legal atinentes a esses modos de satisfazer a prestação. Os que assim procedem violam, com um ato, o crédito. Comportam-se diferentemente de quem atrasa o pagamento, pelo que incorreto será dizer que incorrem na mora.

A estas violações positivas de crédito, aplicam-se, entretanto, por analogia, as regras da mora. Daí, a confusão. Verifica-se apenas tratamento analógico, e, assim, tal como na mora, o devedor responde pelo cumprimento defeituoso, devendo indenizar o prejuízo a que der causa, se a imperfeição lhe for imputável, ainda quando, da infração, não resulte impossibilidade ou mora. ${ }^{305}$

Marcos Jorge Catalan também entende que "a idéia de mora está umbilicalmente ligada ao atraso ou retardamento da prestação que ainda é útil ao

${ }^{304}$ GOMES, Orlando. Obrigações. 16. ed. rev., atual. e aum., de acordo com o Código Civil de 2002, por Edvaldo Brito. Rio de Janeiro: Forense. 2005. p. 198.

${ }^{305}$ GOMES, Orlando. Obrigações. 16. R ed. rev., atual. e aum., de acordo com o Código Civil de 2002, por Edvaldo Brito. Rio de Janeiro: Forense. 2005. p. 205-206. 
credor" ${ }^{306}$, afirmando categoricamente que "o legislador pátrio desrespeitou um conceito criado ao longo de séculos ao ampliar a noção de mora, não lhe dando o adequado tratamento científico, pois, aparentemente, o que se tem quando da ofensa dos critérios lugar e modo, não será a simples mora (atraso), mas, lesão positiva do contrato"307.

Desta feita, o mencionado autor defende a aplicação da teoria da violação positiva do crédito (sob a denominação de cumprimento inexato) para todos aqueles casos em que não se está diante de atraso ou inexecução definitiva, mas sim de deficiências ou defeitos relacionados a qualidade da prestação ou ainda a violação de direitos anexos ou laterais decorrentes da boa-fé objetiva ${ }^{308}$.

A orientação mais difundida na doutrina brasileira é no sentido de que, embora os conceitos pátrios de mora e vícios redibitórios abarquem várias das hipóteses concebidas no direito estrangeiro como violação positiva do crédito, os referidos institutos não abrangeriam o descumprimento dos deveres anexos impostos pela boa-fé en $^{309}$. Assim, a doutrina brasileira majoritária defende que a teoria da violação positiva do crédito deve ser aplicada para casos em que há a violação de deveres anexos que não estejam diretamente vinculados à prestação principal ${ }^{310}$.

${ }^{306}$ CATALAN, Marcos Jorge. Descumprimento contratual. Curitiba: Juruá, 2005. p. 138.

${ }^{307}$ CATALAN, Marcos Jorge. Descumprimento contratual. Curitiba: Juruá, 2005. p. 140-141.

308 Segue trecho que sistematiza o entendimento de Marcos Jorge Catalan sobre o tema: "É imperioso distinguir o cumprimento inexato das figuras da mora, oriunda do não desempenho da prestação no momento propicio para o pagamento e do inadimplemento, que implica a inviabilidade definitiva de cumprimento em razão de sua impossibilidade superveniente, seja ela física ou jurídica, ou ainda, quando derivar da perda do interesse do credor no desempenho da prestação. Desse modo, ter-se-á cumprimento inexato ou defeituoso quando o desempenho da prestação não observar o princípio da pontualidade, o que pode se dar por três vias: a) quando o objeto do pagamento, tenha este origem em um dar ou em um fazer, estiver viciado qualitativamente; b) quando o devedor deixar de observar a dever lateral de conduta; e c) quando for desrespeitado um dever acessório; em quaisquer dos casos, sendo imperiosa a presença de danos típicos, ou seja, os que não seriam causados nas hipóteses de mora e inadimplemento." CATALAN, Marcos Jorge. Descumprimento contratual. Curitiba: Juruá. 2005. p. 161-163.

${ }^{309}$ TERRA, Aline de Miranda Valverde. Inadimplemento anterior ao termo. Rio de Janeiro: Renovar. 2009. p. 111.

${ }^{310}$ Nesse sentido, Ubirajara Mach de Oliveira defende que: "No que tange ao direito brasileiro, ressalve-se que as hipóteses de cumprimento imperfeito, inclusive por defeito qualitativo (violação quanto à forma e ao modo da prestação), são absorvidas pelo conceito de mora. Logo, não tivemos a mesma dificuldade sentida pela doutrina alemã, que necessitou derivar, na espécie, para a teoria da infração contratual positiva. O que a nossa legislação não refere é a violação dos deveres laterais, embasados no princípio da boa-fé objetiva, e a quebra antecipada do contrato." OLIVEIRA, Ubirajara Mach de. Quebra positiva do contrato. Revista de Direito do Consumidor. v. 25. Jan. 1998. p. 41. Adotando o mesmo posicionamento: "Enquanto o inadimplemento absoluto e a mora concernem a cumprimento do dever de prestação, a violação positiva do 
Com efeito, Jorge Cesa Ferreira da Silva afirma que a teoria da violação positiva do crédito deve ser aceita no direito brasileiro, mas com a necessária "aclimatação". Segundo o referido autor, o direito brasileiro se distingue do BGB e de outros ordenamentos jurídicos do sistema romano-germânico ao prever (i) as regras gerais de vícios redibitórios, aplicáveis a todos os contratos que se incluam nos requisitos nela indicados, sejam eles típicos ou atípicos, bem como (ii) um conceito de mora que não se limita ao mero atraso da prestação em si, mas abarca todas as situações que venham a “atrasar a satisfação dos interesses do credor"311.

O mencionado autor prossegue afirmando que várias hipóteses aceitas no direito estrangeiro como violação positiva do crédito encontram-se subsumidas na mora e nos vícios (redibitórios ou do Código de Defesa do Consumidor), mas conclui que "o mesmo não se pode dizer do descumprimento de deveres laterais. Esses deveres não dizem respeito diretamente à realização da prestação, mas sim ao melhor adimplemento, vale dizer, aquele que atinja mais perfeita e eficazmente o resultado esperado sem causar danos à outra parte e a terceiros. [...] Havendo descumprimento desses deveres [...], a violação positiva do contrato é chamada a atuar também no direito brasileiro, visto inexistir outra ferramenta conceitual que abarque a hipótese" ${ }^{312}$.

Portanto, para Jorge Cesa Ferreira da Silva, "a violação positiva do contrato, no direito brasileiro, corresponde ao inadimplemento decorrente do descumprimento de dever lateral, quando este dever não tenha uma vinculação direta com os interesses do credor na prestação" ${ }^{313}$.

contrato aplica-se a uma série de situações práticas de inadimplemento que não se relacionam com a obrigação principal - mais precisamente, o inadimplemento derivado da inobservância dos deveres laterais ou anexos." FARIAS, Cristiano Chaves de; ROSENVALD, Nelson. Direito das obrigações. 2011. p. 553.

311 SILVA, Jorge Cesa Ferreira da. Inadimplemento das obrigações. São Paulo: Editora Revista dos Tribunais. 2007. p 44.

${ }^{312}$ SILVA, Jorge Cesa Ferreira da. Inadimplemento das obrigações. São Paulo: Editora Revista dos Tribunais. 2007. p. 44-45.

${ }^{313}$ SILVA, Jorge Cesa Ferreira da. A boa-fé e a violação positiva do contrato. Rio de Janeiro: Renovar. 2002. p. 266. 
Essa também é a posição de Ruy Rosado Aguiar Júnior acerca da aplicação da teoria da violação positiva do contrato no direito brasileiro:

\begin{abstract}
No Brasil, o conceito de mora absorve as hipóteses de cumprimento imperfeito, inclusive por defeito qualitativo (violação quanto à forma e ao modo da prestação), razão pela qual não sentimos a mesma dificuldade enfrentada pela doutrina alemã, que derivou para a teoria da violação contratual positiva. Isso relativamente às obrigações convencionadas, principais ou acessórias. A omissão da nossa lei está em deixar de referir a violação aos deveres secundários, emanados diretamente da boa-fé (o que se compreende, pois nem sequer o princípio ficou expressamente consagrado). ${ }^{314}$
\end{abstract}

A posição da doutrina majoritária pode ser sintetizada pelo Enunciado $\mathrm{n}^{\mathrm{o}} 24$ do Conselho da Justiça Federal, que assevera: "em virtude do princípio da boa-fé, positivado no art. 422 do novo Código Civil, a violação dos deveres anexos constitui espécie de inadimplemento, independentemente de culpa." ${ }^{315}$

Com relação aos efeitos da "violação positiva do contrato", Karl Larenz entende que o descumprimento de um dever de conduta ou dever lateral derivado da boa-fé desencadeia uma obrigação de indenizar e, em algumas situações, confere à outra parte o direito de resolver o contrato ${ }^{316}$.

De acordo com a doutrina brasileira majoritária, o descumprimento de deveres laterais poderá resultar na resolução ou na oposição da exceção do contrato não cumprido, se importantes os reflexos do dever anexo violado para o contrato. De outra parte, tendo o descumprimento do dever lateral pouca importância, a resolução e a exceção serão

\footnotetext{
314 AGUIAR JÚNIOR, Ruy Rosado de. Extinção dos contratos por incumprimento do devedor. 2. Ed. Rio de Janeiro: AIDE. 1991. p.126.

${ }^{315}$ Em comentário sobre o referido enunciado, Adisson Leal afirma que "com esta construção interpretativa, não se cria nova situação de responsabilidade civil objetiva, ao arrepio da Lei ou da caracterização de atividades de risco. Simplesmente realiza-se uma adequada interpretação do art. 422 e das consequências jurídicas da violação de deveres anexos, ou seja, da violação positiva dos contratos. De fato, se a boa-fé objetiva dispensa abordagens o campo anímico do sujeito, a culpa não será elemento essencial para a caracterização do dever de indenizar por violações positivas do contrato". LEAL, Adisson. Violação Positiva dos Contratos. In: Responsabilidade civil e inadimplemento no direito brasileiro. ANDRIGHI, Fátima Nancy Andrighi (Coord.). São Paulo: Atlas. 2014. p. 13.

${ }^{316}$ LARENZ, Karl. Derecho de obligaciones. tomo I. Trad. de Jaime Santos Briz. Madrid: Editora Revista de Derecho Privado. 1958. p. 22.
} 
consideradas desproporcionais e abusivas, na esteira da doutrina do adimplemento substancial, sendo cabível o pagamento de uma indenização ${ }^{317}$.

É essa a posição de Ubirajara de Oliveira sobre o tema:

\begin{abstract}
Advirta-se, porém, que a possibilidade de resolução, decorrente da infração contratual positiva, fica subordinada ao juízo da gravidade da violação. Há que se avaliar em quanto o incumprimento compromete o interesse do credor na prestação. Bem pode ser que subsista mencionado interesse, seja em virtude de ter ocorrido, já, um adimplemento substancial, seja porque não afetada a integridade da prestação em si considerada. Se o prejuízo for meramente suplementar, viável será o pedido de perdas e danos, mas não o de resolução, e nem tampouco a exceção de contrato não cumprido. ${ }^{318}$
\end{abstract}

Concordamos que várias hipóteses aceitas no direito estrangeiro como violação positiva do crédito encontram-se subsumidas no conceito legal de mora e de vícios (redibitórios ou do Código de Defesa do Consumidor) $^{319}$. No entanto, diferentemente da

317 SILVA, Jorge Cesa Ferreira da. Inadimplemento das obrigações. São Paulo: Editora Revista dos Tribunais. 2007. p. 47. No mesmo sentido, Adisson Leal leciona que "sob o prisma da resolução do contrato, também a gravidade da violação positiva deve receber especial atenção. Isto porque, pela primazia da manutenção do vínculo contratual, apenas as violações que ponham em xeque o vínculo contratual como um todo poderão legitimar a pretensão resolutória. De fato, poderá haver situações em que as prestações contratuais tenham sido cumpridas à risca, mas algum aspecto do comportamento de um dos contratantes revele uma violação da boa-fé. Neste caso, havendo adimplemento substancial, não haverá espaço para a pretensão resolutória fundada na violação positiva do contrato. Sob o mesmo fundamento, a exceção do contrato não cumprido encontra óbices na ideia de adimplemento substancial, pelo que não poderá ser invocada pelo credor se o devedor adimpliu substancialmente as obrigações que lhe incumbiam". LEAL, Adisson. Violação Positiva dos Contratos. In: ANDRIGHI, Fátima Nancy Andrighi (Coord.). Responsabilidade civil e inadimplemento no direito brasileiro. São Paulo: Atlas. 2014, p. 13.

318 OLIVEIRA, Ubirajara Mach de. Quebra positiva do contrato. Revista de Direito do Consumidor. v. 25, Jan. 1998, p. 49. No mesmo sentido se posiciona Ruy Rosado: “[...] o descumprimento de um dever secundário, quando ligado à prestação principal, pode atingir, tal seja sua gravidade, a própria prestação e significar o descumprimento da obrigação, ou o seu cumprimento imperfeito. Contudo, há casos em que o incumprimento do dever secundário não se relaciona diretamente com a prestação, que pode ter sido prestada integral e convenientemente, ou ainda não prestada por não ter chegado o tempo do adimplemento. É o caso do prestador de serviços que realiza a contento o seu trabalho, mas age com descuido ao se retirar da casa, causando danos ao patrimônio ou à pessoa do proprietário; houve violação ao dever de proteção, ensejando a interrupção do contrato, que previa uma segunda etapa. Também, ainda antes do vencimento, o contratante pode claramente demonstrar que não irá adimplir. Nestas duas últimas situações, não se pode falar em incumprimento da prestação, porquanto na primeira houve o cumprimento e, na segunda, ainda não chegara o seu tempo; são, na verdade, hipóteses de 'infração positiva do contrato', por violação a deveres secundários de proteção ou lealdade.” AGUIAR JR., Ruy Rosado. Extinção dos contratos por incumprimento do devedor (resolução). Rio de Janeiro: Aide. 1991. p. 247.

${ }^{319}$ No mesmo sentido se posiciona Gustavo Rocha Furtado: “[...] é exatamente pelo fato de a mora no direito brasileiro englobar os fatores espacial e modal, afastando-se da definição mais enxuta feita alhures que a restringe ao fator temporal, que a teria da violação positiva do contrato, engendrada no direito alemão, tem pouca adequação e precisão no ordenamento jurídico nacional. Isso porque, diferentemente da brasileira, a lei germânica - para a qual tal teoria foi formulada - à época nada dispunha sobre os casos em que o devedor 
doutrina majoritária, não vislumbramos a necessidade de se utilizar da teoria da violação positiva do contrato como uma terceira modalidade de inadimplemento para abarcar as hipóteses em que há o descumprimento de deveres anexos.

Conforme analisado acima, diante das alterações que o princípio da boa-fé objetiva promoveu no direito obrigacional, há apenas uma prestação devida, isto é, existe um único comportamento capaz de realizar plenamente o interesse do credor: o comportamento que executa o dever principal, os deveres secundários e os deveres laterais.

Somente quando o devedor observar todos os deveres (principais, secundários e anexos) é possível falar que ele cumpriu a prestação devida e que houve o adimplemento perfeito da obrigação. A contrario sensu, quando o devedor não cumprir todos os deveres obrigacionais, independentemente da sua natureza ou classificação, há inadimplemento (em sentido amplo).

Nessa linha se posiciona Anderson Schreiber:

\begin{abstract}
$\mathrm{Na}$ perspectiva funcional, em que o adimplemento consiste simplesmente no cumprimento da prestação principal, a tutela do crédito em tais hipóteses exige mesmo o recurso a alguma figura ou norma externa à disciplina do adimplemento, como a violação positiva do contrato ou o (mais direto) recurso à cláusula geral de boa-fé objetiva (art. 422). Não é, todavia, o que ocorre em uma perspectiva funcional, na qual o cumprimento da prestação principal não basta à configuração do adimplemento, exigindo-se o efetivo atendimento da função concretamente atribuída pelas partes ao negócio jurídico celebrado, sem o qual todo o comportamento (positivo ou negativo) do devedor mostra-se insuficiente. Vale dizer: revisitado o conceito de adimplemento, as hipóteses hoje solucionadas pela violação positiva do contrato tendem a recair em seu âmago interno, corroborando a necessidade de um exame que abarque o cumprimento da prestação contratada também sob o seu prisma funcional. ${ }^{320}$
\end{abstract}

Portanto, não importa se o dever violado é dever de prestação principal, secundário ou anexo, já que todos eles se incluem no campo mais amplo de prestação

violasse a obrigação através de uma atuação positiva, isto é, fazendo o que devia omitir ou efetuando a conduta devida, mas em termos imperfeitos." FURTADO, Gabriel Rocha. Mora e inadimplemento substancial. São Paulo: Atlas. 2014. p. 17.

${ }^{320}$ SCHREIBER, Anderson. A Boa-fé objetiva e o Adimplemento Substancial. In: HIRONAKA, Giselda Maria Fernandes Novaes; TARTUCE, Flávio (Coord.), Direito contratual. Temas Atuais. São Paulo: Método. 2007. p. 137. 
devida. A violação de quaisquer deveres conduz à não execução do comportamento devido, ao não cumprimento da prestação devida e, consequentemente, ao inadimplemento (em sentido amplo).

Agora, se a violação a um dever obrigacional (principal, secundário ou anexo) acarreta a mora ou o inadimplemento absoluto (espécies de inadimplemento), isto é uma questão que apenas se responde à luz do caso concreto, de acordo com a possibilidade ou não de adimplemento, bem como da manutenção ou não do interesse do credor e da possibilidade de se produzir o resultado útil programado ${ }^{321}$.

O descumprimento de quaisquer deveres obrigacionais, inclusive deveres anexos, configurará inadimplemento absoluto, se a prestação devida se tornar impossível ou inútil para o credor; ou mora, desde que o seu cumprimento se afigure possível ao devedor e útil ao credor. Não há, portanto, necessidade de se valer da violação positiva do crédito como uma terceira modalidade de inadimplemento.

Saliente-se que a teoria do adimplemento substancial (decorrente da função restritiva da boa-fé objetiva) permite balizar os efeitos dessa nova concepção de inadimplemento, que abrange até mesmo o descumprimento de deveres anexos. Assim, tendo o descumprimento do dever lateral sido de pouca importância e de pouca repercussão no cumprimento da prestação devida, a resolução e a exceção de contrato não cumprido serão consideradas medidas desproporcionais e abusivas. Na hipótese de o prejuízo do credor com o descumprimento de dever lateral ser meramente suplementar, somente será viável o pedido de indenização por perdas e danos. Caso contrário, seria atribuído ao devedor sacrifício desproporcional diante de descumprimento de pouca monta.

Destaque-se que o tratamento unitário das diversas obrigações e deveres contratuais se impõe como uma tendência internacional, a exemplo do que ocorreu na Alemanha com a modernização do BGB. A esse respeito, Jorge Cesa Ferreira da Silva assevera que "a alteração dos textos dedicados ao inadimplemento no BGB afastou-se do

${ }^{321}$ TERRA, Aline de Miranda Valverde. Inadimplemento anterior ao termo. Rio de Janeiro: Renovar. 2009. p. 112-113. 
modelo anterior, ancorado nas figuras individuais do descumprimento, para fulcrar-se em uma figura geral, chamada 'violação de dever' (Pflichtverletzung). Hoje, se verifica houve alguma violação de dever e, em caso positivo, analisa-se quais os efeitos incidentes. Entre os deveres obrigacionais, o BGB passou a incluir, expressamente, os deveres laterais, no $\S$ 241, II, de modo a deixar claro que o desrespeito a deveres de conduta igualmente se inclui na figura geral" ${ }^{\prime 322}$.

Nessa direção, a Convention on Contracts for the International Sales of Goods, elaborada em Viena em 1980, ao tratar de inadimplemento fundamental, não distingue dever principal ou obrigação acessória ou dever anexo. A referida convenção dispensa tratamento unitário a todos os deveres obrigacionais, de modo que, para fins resolutórios, não importa qual dever que restou violado, mas os efeitos dessa violação, isto é, se encerra ou não inadimplemento substancial ${ }^{323}$.

Confira-se, abaixo, a definição de inadimplemento fundamental constante do artigo 25 da Convention on Contracts for the International Sales of Goods:

\begin{abstract}
A breach of contract committed by one of the parties is fundamental if it results is such detriment to the other party as substantially to deprive him of what he is entitled to expect under the contract, unless the party in breach did not foresee and a reasonable person of the same circumstances would not have foreseen such a result. ${ }^{324}$
\end{abstract}

A respeito do mencionado artigo da Convenção, Véra Maria Jacob de Fradera comenta justamente que o conceito de inadimplemento fundamental não distingue dever

\footnotetext{
322 SILVA, Jorge Cesa Ferreira da. Inadimplemento das obrigações. São Paulo: Editora Revista dos Tribunais. 2007. p. 48.

${ }^{323}$ TERRA, Aline de Miranda Valverde. Inadimplemento anterior ao termo. Rio de Janeiro: Renovar. 2009. p. 115-116. A esse respeito, Schlechtriem \& Schwenzer afirmam que "uma violação contratual nos termos do art. 25 existe quando a quebra de qualquer obrigação contratual ocorrer, independentemente, de esta ter sido especificamente inserida no contrato de compra e venda ou de decorrer das demais regras da Convenção". SCHLECHTRIEM, Peter; SCHWENZER, Ingeborg. Comentários à Convenção das Nações Unidas sobre Contratos de Compra e Venda Internacional de Mercadorias. Coordenação de tradução de Eduardo Grebler, Vera Fradera, César Guimarães Pereira. São Paulo: Editora Revista dos Tribunais. 2014. p. 531.

${ }^{324}$ Em tradução livre: "A violação ao contrato por uma das partes é considerada como essencial se causar à outra parte prejuízo de tal monta que substancialmente a prive do resultado que poderia esperar do contrato, salvo se a parte infratora não tiver previsto e uma pessoa razoável da mesma condição e nas mesmas circunstâncias não pudesse prever tal resultado."
} 
principal ou obrigação acessória ou dever anexo, e considerou a obrigação contratual como uma complexidade:

\begin{abstract}
É nosso entendimento, que a comissão elaboradora da Lei Internacional sobre Venda de Coisas Móveis, pela maneira como conceitua o inadimplemento fundamental do contrato, no art. 25 dessa lei, considerou a obrigação contratual como uma complexidade, uma estrutura (Gefuege) ou mesmo uma forma (Gestalt), o que vem a ser, em última análise, a mesma idéia, ou sejam a relação contratual é vista não como um vínculo entre dois sujeitos em posição antagônica, mas sim um vínculo que estabelece uma ordem de cooperação entre os sujeitos, ativo e passivo. Em decorrência dessa necessidade de cooperação, surgem, em virtude da aplicação do princípio da boa-fé, os denominados deveres acessórios, cuja finalidade é a de que, no cumprimento da obrigação, tudo se passe de modo considerado como devido. É justamente o que se depreende do disposto no art. 25 da Lei Internacional sobre Venda de Bens Móveis que, ao conceituar o que seja inadimplemento fundamental do contrato, considera como tal, "aquele que redunda em prejuízo para a outra parte, a ponto de privá-la daquilo que podia esperar do contrato". Aqui claramente se percebe o que Siebert/Knopp definem como boa-fé, "a imposição de consideração pelos interesses legítimos da contraparte". ${ }^{325}$
\end{abstract}

Os princípios UNIDROIT relativos aos Contratos Comerciais Internacionais também se orientam no mesmo sentido: "Artigo 7.1.1. O inadimplemento consiste na quebra por uma parte de quaisquer de suas obrigações contratuais, incluindo a prestação defeituosa ou a prestação tardia.” A respeito do referido princípio, João Baptista Villela comenta que “"inadimplemento' é definido de modo a compreender todas as formas de execução defeituosa, bem como a falta completa de execução. Assim, há inadimplemento quando um construtor ergue uma edificação que em parte guarda conformidade com o contrato, mas em parte não, ou que completa a obra tardiamente",326.

Acrescente-se que na obra Principles, definitions and model rules of european private law, em que consta um esboço de Código Civil a ser adotado nos países que compõem a União Europeia - "Draft Common Frame of Reference (DCFR)" - também está previsto no artigo 502 que " a creditor may terminate if the debtor's non performance

\footnotetext{
${ }^{325}$ FRADERA, Véra Maria Jacob de Fradera. O Conceito de Inadimplemento Fundamental do Contrato no Artigo 25 da Lei Fundamental do Contrato no Artigo 25 da Lei Internacional sobre Vendas, da Convenção de Viena de 1980. Direito, Estado e Sociedade. Rio de Janeiro, n. 9, ago./dez. 1996, p. 143-144.

326 VILLELA, João Baptista et al. Princípios UNIDROIT relativos aos Contratos Comerciais Internacionais/2004 [versão em língua portuguesa]. São Paulo: Quartier Latin. 2009. p. 205.
} 
of a contractual obligation is fundamental ${ }^{, 327}$, ou seja, que o credor pode resolver o contrato em caso de descumprimento de qualquer obrigação, desde que o inadimplemento seja fundamental ${ }^{328}$.

Nessa direção, uma parcela ainda minoritária da doutrina brasileira começa a questionar a efetiva serventia da utilização da teoria da violação positiva do crédito como terceira espécie de inadimplemento diante das alterações dos conceitos de obrigação, adimplemento e inadimplemento, conforme se observa da obra de Gustavo Tepedino e Anderson Schreiber:

\begin{abstract}
A amplitude, portanto, do conceito de mora no direito brasileiro torna discutível a utilidade, entre nós, da violação positiva do contrato, ou, mais tecnicamente, violação positiva da obrigação. Esforços recentes têm sido empreendidos no sentido de associá-la à violação de deveres de cooperação impostos pela boa-fé objetiva, em construção que, a rigor, dispensaria a importação da figura. De outro lado, a releitura funcional do conceito de adimplemento, a exigir não apenas o cumprimento da prestação principal, mas a realização do escopo comum perseguido pelas partes, afigura-se suficiente a solucionar as hipóteses de cumprimento defeituoso da prestação que, porventura, tenham escapado à noção legal de mora. ${ }^{329}$
\end{abstract}

A nosso ver, o equívoco da doutrina tradicional está em continuar a vislumbrar na mora e no adimplemento absoluto apenas a violação da prestação principal - e não da prestação devida, cujo conteúdo abrange todos os deveres obrigacionais, independentemente da sua natureza -, bem como em não conferir ao conceito de mora a abrangência atribuída pelo próprio legislador pátrio. Observe-se que não se nega a

\footnotetext{
${ }^{327}$ VON BAR, Christian, CLIVE, Eric. Principles, definitions and mode, rules of european private law. Draft Common Frame of Reference (DCRF). Full Edition. v. I. Sellier. p. 867. Em tradução livre: "um credor poderá rescindir o contrato se o inadimplemento contratual for fundamental."

${ }^{328}$ No artigo 502, seção 2, do Draft Common Frame of Reference (DCFR) consta que as seguintes hipóteses caracterizam inadimplemento fundamental: "A non-performance of a contractual obligation is fundamental if (a) it substantially deprives the creditor of what the creditor was entitled to expect under the contract, as applied to the whole or relevant part of the performance, unless at the time of conclusion of the contract the debtor did not foresee and could not reasonably be expected to have foreseen that result; or (b) it is intentional or reckless and gives the creditor reason to believe that the debtor's future performance cannot be relied on." Em tradução livre: "O não cumprimento de uma obrigação contratual é fundamental se (a) o descumprimento substancialmente priva o credor daquilo que ele tinha direito de esperar do contrato, em relação à performance total ou parcial, salvo se no momento da conclusão do contrato o devedor não previu ou não poderia ser razoavelmente esperado que ele tivesse previsto tal resultado; ou (b) o descumprimento é intencional ou culposo e faz com que o credor acredite que ele não possa se basear no futuro cumprimento do devedor."

${ }^{329}$ TEPEDINO, Gustavo. SCHREIBER, Anderson. In: AZEVEDO, Álvaro Villaça (Coord.). Código Civil Comentado: direito das obrigações. São Paulo: Atlas. 2008. p. 343-344.
} 
importância da teoria da violação positiva do crédito, mas se questiona a sua aplicação ao direito brasileiro como uma modalidade autônoma de inadimplemento.

Adotaremos, a partir deste momento, a concepção dinâmica e funcional de obrigação e os conceitos alargados de adimplemento e inadimplemento para deslindar as questões relativas ao inadimplemento antecipado. Porém, não nos esqueceremos da relevância da teoria da violação positiva do contrato, buscando sempre mencioná-la nos momentos oportunos.

\subsection{Os efeitos do inadimplemento, pelo credor, do dever de colaboração}

Antes de adentrar no exame do inadimplemento antecipado, analisaremos brevemente os efeitos da inobservância, pelo credor, do dever de colaboração, tema que se revelará essencial para o presente estudo.

Como discutido anteriormente, a concepção da "obrigação como processo" impõe que o credor deverá observar o dever de colaboração para que o devedor possa cumprir a prestação devida, e por consequência, a obrigação reste adimplida, sendo que esse dever de cooperação é dotado de exigibilidade jurídica ${ }^{330}$. Nesse momento, será feita uma análise dos efeitos da violação desse dever pelo credor, tema ainda pouco discutido na doutrina brasileira.

O artigo 394 do Código Civil preconiza que se considera em mora (mora accipendi) o credor que não quiser receber o pagamento no tempo, lugar e forma que a lei ou a convenção estabelecer. Do conceito legal de mora do credor, é possível extrair os requisitos para a configuração da mora do credor: (i) a oferta do devedor, desde que seja

\footnotetext{
${ }^{330}$ Neste sentido, Thiago Luís Santos Sombra afirma que "se já não há um direito abstrato ao adimplemento pelo devedor, como sustentado, e se o ônus não é apto a encerrar todas as situações, não se pode negar que o dever lateral de cooperação amplia o rol de condutas juridicamente exigíveis do credor em uma relação obrigacional, notadamente quando associado à liberação do vínculo, mediante a imposição e consequências sob os ditames da mora do credor, da impossibilidade superveniente não imputável ao devedor, da culpa in contrahendo e da culpa post pactum finitum. Em poucas palavras, o credor não se revela mais tão árbitro do momento do adimplemento como outrora". SOMBRA, Thiago Luís Santos. Adimplemento contratual e colaboração do credor. São Paulo: Saraiva. 2011. p. 150.
} 
completa, no lugar e tempo oportunos; e (ii) a recusa sem justa causa do credor em recebêla.

No entanto, a nosso ver, o caráter cada vez mais colaborativo da obrigação demonstra a insuficiência do conceito legal de mora accipendi e, por consequência, do atual modelo de proteção dos interesses do devedor frente a condutas do credor que violem os deveres anexos impostos pela boa-fé objetiva, as quais acabam por inviabilizar o adimplemento contratual $^{331}$.

Com efeito, o conceito de mora do credor previsto no artigo 813 do Código Civil português - segundo o qual "o credor incorre em mora quando, sem motivo justificado, não aceita a prestação que lhe é oferecida nos termos legais ou não pratica os actos necessários ao cumprimento da obrigação" ${ }^{332}$ - está mais alinhado com a concepção moderna de obrigação, em que ambas as partes contratantes devem colaborar para que o devedor possa cumprir a prestação devida e possa ser atingido o resultado útil programado.

Consoante observa Judith Martins-Costa, "não só o devedor está numa situação subjetiva de dever, em relação ao credor: este também está em situação de dever em relação ao devedor", de maneira que "ocorre a mora do credor quando este não cumpre

\footnotetext{
${ }^{331}$ Na mesma linha, J. W. Hedemann afirma que "también el acreedor puede incurrir en retraso al no aceptar la prestación ('mora accipiendi'). En tal supuesto, la liquidación de la relación obligatoria queda paralizada por causa del acreedor, con lo cual la llamada mora del acreedor constituye otro 'obstáculo para el cumplimiento de la prestación". HEDEMANN, J.W. Derecho de obligaciones. v. III. Trad. de Jaime Santos Briz. Madrid: Editorial Revista de Derecho Privado. 1958. p. 187. Em tradução livre: "o credor também pode incorrer em mora por não aceitar a oferta ('mora accipiendi'). Nesse caso, o término da relação obrigacional fica paralisado por causa do credor, sendo que a mora do credor constituí outro "obstáculo ao cumprimento da obrigação". A esse respeito, Thiago Luís Santos Sombra ressalta que "é certo que o ordenamento dispõe de alguns poucos métodos de solução voltados para a posição do devedor, como sói ocorrer nos contratos de depósito, empreitada e transporte, por exemplo; porém, carece de uma disciplina mais específica para a inobservância dos deveres laterais e, em especial, o de cooperação por parte do credor [...]". SOMBRA, Thiago Luís Santos. Adimplemento contratual e colaboração do credor. São Paulo: Saraiva. 2011. p. 69.

${ }^{332}$ Em comentários ao artigo 813 do Código Civil português, Almeida Costa afirma que: "Portanto, o atraso no cumprimento será imputável ao credor sempre que este se recuse ilegitimamente a colaborar com o devedor no cumprimento da obrigação - nos termos em que lhe caiba fazê-lo, segundo o caso. A cooperação do credor no cumprimento pode traduzir-se no simples acto de aceitar a prestação, mas pode ainda assumir outras expressões: apresentar-se o devedor, ele próprio ou um seu representante, no lugar convencionado para a prestação (domicílio do devedor ou outro local), exercer o direito de escolha numa obrigação genérica ou alternativa, passar a quitação, restituir o título da dívida, etc.” ALMEIDA COSTA, Mário Júlio de. Noções de direito civil. Coimbra: Livraria Almedina. 1980. p. 225-226.
} 
com o dever de cooperação que lhe concerne, deixando de colaborar para que a dívida seja solvida",333.

Por essa razão, entendemos que a mora do credor deveria passar a ser entendida não apenas como a recusa injustificada em aceitar a prestação devidamente ofertada, mas também como a recusa em cooperar, quando esta colaboração é necessária para viabilizar o adimplemento contratual ${ }^{334}$. Nas palavras de Pontes de Miranda, a "mora do credor é a omissão do credor em cooperar para que a dívida se solva, até onde essa cooperação é indispensável"335.

Dentro dessa visão, para que se caracterize a mora do credor, é necessário que (i) o devedor tenha que prestar e possa prestar; (ii) o inadimplemento decorra de fato imputável ao credor; e (ii) o credor tenha recusado ou omitido ato positivo ou negativo de cooperação indispensável para que ocorra o adimplemento ${ }^{336}$.

\footnotetext{
${ }^{333}$ MARTINS-COSTA, Judith. Comentários ao novo Código Civil. Rio de Janeiro: Forense. 2004. p. 240. No mesmo sentido, Thiago Luís Santos Sombra acrescenta que "é inconteste, e a doutrina majoritária atesta este ponto, que, quando a cooperação seja essencial ao adimplemento, a conduta omissiva se subsume aos preceitos da mora creditoris, afinal sem a cooperação não se viabiliza a execução, a oblação e, por conseguinte, sequer de recusa ou aceitação do credor se perquirirá". SOMBRA, Thiago Luís Santos. Adimplemento contratual e colaboração do credor. São Paulo: Saraiva. 2011. p. 70-71.

${ }^{334}$ CARVALHO SANTOS, J. M. Código Civil brasileiro interpretado. v. XII. Direito das obrigações. 7. ed. Rio de Janeiro: Freitas Bastos. 1958. p. 319. No mesmo sentido: "A mora do credor pode ser conceituada como a recusa injustificada de aceitar a prestação devidamente ofertada, ou de aceder ao convite do credor para prestar a sua cooperação, quando está é necessária para tornar a prestação materialmente possível." SAVI, Sérgio. Inadimplemento das Obrigações, Mora e Perdas e Danos. In: TEPEDINO, Gustavo (Coord.). Obrigações: estudos na perspectiva civil-constitucional. Rio de Janeiro: Renovar. 2005. p. 472. Nas lições de Agostinho Alvim, "se para liquidar a obrigação é necessária a cooperação do credor, escusar-se-á o devedor sempre que aquêle lhe negar. É um caso de mora accipiendi". ALVIM, Agostinho. Da inexecução das obrigações e suas consequências. 3. ed. atual. Rio de Janeiro: Editora Jurídica e Universitária Ltda. 1949. p. 39. Antunes Varella destaca que "diz-se que há mora do credor (mora credendi), quando a obrigação se não cumpre, porque o credor, sem causa justificativa, recusa a prestação que lhe é regularmente oferecida ou não realiza os actos de sua parte necessários ao cumprimento". VARELA, João de Mattos Antunes. Das obrigações em geral. Coimbra: Almedina. 1970. p. 781. No mesmo sentido, Giovanni Ettore Nanni afirma que "a falta de cooperação do credor é pressuposto da mora accipiendi, a qual pode ser exigida em várias situações: ir ao encalço do devedor, buscar a quantia ou coisa, exercitar o direito de escolha, apresentar as contas, fornecer o material, intervir com a própria presença etc." NANNI, Giovanni Ettore. O dever de cooperação nas relações obrigacionais à luz do princípio constitucional da solidariedade. In: NANNI, Giovanni Ettore (Coord.). Temas relevantes do direito civil contemporâneo: reflexões sobre os cinco anos do Código Civil. São Paulo: Atlas. 2008. p. 316.

${ }_{335}$ PONTES DE MIRANDA, Francisco Cavalcanti. Tratado de direito privado. tomo XXIII. São Paulo: Editora Revista dos Tribunais. p. 288-289.

${ }^{336}$ PONTES DE MIRANDA, Francisco Cavalcanti. Tratado de direito privado. tomo XXIII. São Paulo: Editora Revista dos Tribunais. p. 288-294.
} 
Importante salientar que não se exige, para que se possa considerar o credor constituído em mora, que a sua não cooperação seja devida a procedimento culposo. Para caracterizar a mora do credor, basta a "inexistência de motivo justificado",337 para o credor não aceitar a prestação no tempo, local e modo pactuados e/ou não colaborar com o devedor no programa obrigacional. Daí porque Agostinho Alvim afirmou que "a justa ou injusta causa da recusa influenciam sôbre a mora do credor" e que "a culpa é indiferente" 338 .

Por adotarmos uma concepção ampla de inadimplemento (conforme examinado no item anterior), consideramos que não importa se o dever de colaboração violado pelo credor é dever de prestação principal, secundário ou anexo. A violação de qualquer dever de colaboração, desde que relevante, conduz à mora creditoris, que acarretará as consequências a serem examinadas na sequência.

Novamente, não há a necessidade de se valer da teoria da violação positiva do crédito para explicar a situação de descumprimento de dever lateral de colaboração pelo credor. Um conceito amplo de mora do credor, visualizado à luz da concepção de “obrigação como processo", é suficiente para abarcar essa questão. Da mesma forma entende Thiago Luís Santos Sombra:

Se o cumprimento imperfeito, compreendido por muitos autores como modalidade de violação positiva do contrato, situa-se em nosso ordenamento jurídico no campo da mora, bem como abrange os deveres laterais, justificado

\footnotetext{
${ }^{337}$ ALMEIDA COSTA, Mário Júlio de. Noções de direito Civil. Coimbra: Livraria Almedina. 1980. p. 232.

${ }^{338}$ ALVIM, Agostinho. Da inexecução das obrigações e suas consequências. 3. ed. atual. Rio de Janeiro: Editora Jurídica e Universitária Ltda. 1949. p. 32. No mesmo sentido, Judith Martins-Costa: "De há muito estão ultrapassadas as concepções que requeriam a culpa no suporte fático para caracterizar a mora do credor. Mesmo os que não dispensam a culpa como elemento da mora do devedor a afastam da mora creditoris, como o faz Agostinho Alvim, que só a tem como 'indiferente'. O credor deve receber, pois se assim não ocorrer, o devedor não se poderá liberar e o adimplemento - fim precípuo da relação obrigacional - não será atingido. O problema central aí é outro, qual seja o da justa causa para não receber a prestação." MARTINSCOSTA, Judith. Comentários ao novo Código Civil. Rio de Janeiro: Forense. 2004. p. 240-240. Luis DiezPicazo e Antonio Gullon também entendem que "la mora credendi no exige ninguna especial culpabilidad del acreedor moroso, sino simplemente la negativa sin razón a recibir”. DIEZ-PICAZO, Luis e GULLON, Antonio. Sistema de derecho civil. v. II. Madrid: Editorial Tecnos. 1978. p. 174. Em tradução livre: "a mora credendi não exige a culpa do credor em atraso, mas sim simplesmente a recusa injustificada de receber."
} 
resulta o posicionamento que entende estar a infringência ao dever lateral de cooperação também inserida na mora creditoris. ${ }^{339}$

Vale destacar que, quando o credor deixa de cumprir deveres primários ou secundários ou, ainda, deveres de conduta impostos pela boa-fé objetiva ${ }^{340}$, tais como o dever de colaboração, isso pode retardar o adimplemento pelo devedor ou acarretar a impossibilidade de cumprimento da obrigação, ou seja, um inadimplemento absoluto por fato imputável ao credor ${ }^{341}$.

A esse respeito, Agostinho Alvim afirma que "se há mero atraso do credor em cooperar ou receber, verifica-se a mora" (por exemplo, o credor que não se dispõe a receber a prestação) e "se o credor deixa de cooperar, quando tal obrigação lhe assiste, e o cumprimento da obrigação, por parte do devedor, se tornou impossível, terá havido inadimplemento absoluto por parte do credor" (por exemplo, o empresário que não procurou obter teatro onde pudesse ser realizado um determinado recital) ${ }^{342}$.

De maneira sistemática, podemos afirmar que, em regra, se o credor descumpre o seu dever de cooperar com o programa obrigacional, inclusive quanto aos deveres laterais, verifica-se uma situação de mora accipiendi; todavia, se esse descumprimento tornar impossível ou extremamente oneroso, por parte do devedor, a entrega da prestação

339 SOMBRA, Thiago Luís Santos. Adimplemento contratual e colaboração do credor. São Paulo: Saraiva. 2011. p. 78 .

${ }^{340}$ A esse respeito, Luis Diez-Picazo e Antonio Gullon comentam que "la imputabilidad al acreedor de su propia insatisfacción puede ser consecuencia de la falta de cumplimiento por el mismo de su carga de cooperar con el deudor, a fin de que este se encuentre en las necesarias condiciones para llevar a cabo la prestación prometida". DIEZ-PICAZO, Luis e GULLON, Antonio. Sistema de derecho civil. v. II. Madrid: Editorial Tecnos. 1978. p. 172. Em tradução livre: "a atribuição ao credor de sua própria insatisfação pode resultar da inobservância do seu dever de cooperar com o devedor, para que este tenha as condições necessárias para realizar a prestação devida."

${ }^{341}$ HEDEMANN, J.W. Derecho de obligaciones. v. III. Trad. de Jaime Santos Briz. Madrid: Editorial Revista de Derecho Privado. 1958. p. 113. No mesmo sentido: "El hecho de que la responsabilidad del deudor constituya el supuesto normal y el de más frecuente examen, no excluye que, por lo menos en algunos casos, la infracción del crédito o su insatisfacción puedan ser imputados al propio acreedor." DIEZ-PICAZO, Luis; GULLON, Antonio. Sistema de derecho civil. v. II. Madrid: Editorial Tecnos. 1978. p. 172. Em tradução livre: "O fato de que a responsabilidade do devedor constitui o curso normal e a hipótese mais frequente não exclui que, pelo menos em alguns casos, a violação de crédito ou insatisfação possam ser atribuídas ao credor."

${ }^{342}$ ALVIM, Agostinho. Da inexecução das obrigações e suas consequências. 3. ed. atual. Rio de Janeiro: Editora Jurídica e Universitária Ltda. 1949. p. 51-52. 
devida, terá havido inadimplemento absoluto por fato imputável ao credor. A importância prática dessa diferenciação reside nas suas consequências, conforme se verá adiante.

Este também é o posicionamento adotado por Giovanni Ettore Nanni:

[...] no que concerne à violação dos deveres laterais propriamente ditos, e especialmente do dever de cooperar, tal transgressão acarreta a obrigação de reparar os danos causados, que poderá se resumir às consequências de um adimplemento defeituoso (prestação debitória realizada com deficiências) ou um inadimplemento absoluto, se a violação chegar a frustrar o próprio adimplemento. $^{343}$

Caso a violação do dever de cooperação pelo credor enseje uma situação de mora accipiendi, o devedor continuará vinculado ao cumprimento da obrigação, mas estarão presentes os efeitos da mora do credor previstos no artigo 400 do Código Civil ${ }^{344}$, a saber, (i) a isenção da responsabilidade do devedor pela conservação da coisa (salvo em caso de dolo), ou seja, há uma diminuição da responsabilidade do devedor, que somente responderá pela eventual deterioração da coisa em caso de dolo; (ii) a obrigação de ressarcir as despesas feitas pelo devedor com a conservação da coisa, bem como os prejuízos que a sua mora tiver causado ao devedor; e (iii) a obrigação do credor de receber a coisa pela estimação mais favorável ao devedor, em caso de oscilação de preço entre o dia estabelecido e o dia da purgação da mora ${ }^{345}$.

Vale transcrever os preciosos ensinamentos de Karl Larenz sobre a questão:

La conducta del acreedor puede retrasar también el cumplimiento de la obligación o provocar para el deudor la imposibilidad de cumplirla. Puede tener lugar este retraso cuando el acreedor no acepta la prestación que le es ofrecida en tiempo y lugar oportunos, obstaculizando así que el resultado de la prestación se produzca oportunamente o faltando en otros casos a su colaboración en el cumplimiento, sin la cual no puede éste ser llevado a cabo por el deudor. En ambos casos hablamos de mora accipiendi o mora del acreedor. Como es natural

\footnotetext{
343 NANNI, Giovanni Ettore. O dever de cooperação nas relações obrigacionais à luz do princípio constitucional da solidariedade. In: NANNI, Giovanni Ettore (Coord.). Temas relevantes do direito civil contemporâneo: reflexões sobre os cinco anos do Código Civil. São Paulo: Atlas. 2008. p. 317.

${ }^{344}$ Art. 400. A mora do credor subtrai o devedor isento de dolo à responsabilidade pela conservação da coisa, obriga o credor a ressarcir as despesas empregadas em conservá-la, e sujeita-o a recebê-la pela estimação mais favorável ao devedor, se o seu valor oscilar entre o dia estabelecido para o pagamento e o da sua efetivação.

${ }^{345}$ ALMEIDA COSTA, Mário Júlio de. Noções de direito civil. Coimbra: Livraria Almedina. 1980. p. 232.
} 
que el deudor no responda del retraso únicamente producido por la conducta del acreedor, se ve aquél libre en estos supuestos de las consecuencias de la mora del deudor. Aunque ciertamente continúe obligado a la prestación, en cuanto y en tanto su cumplimiento sea todavía posible. ${ }^{346}$

Pode-se citar o caso em que o Superior Tribunal de Justiça ${ }^{347}$ entendeu que empresa brasileira devedora de valor à empresa italiana não estaria em mora ao deixar de realizar o pagamento devido, na medida em que a empresa italiana não cooperou para possibilitar a remessa do valor à Itália, deixando de estar devidamente registrada no Banco Central do Brasil, o que era indispensável para a remessa dos fundos. Assim, o Superior Tribunal de Justiça não condenou a devedora em juros de mora, por entender que houve mora da credora em seu dever de cooperar.

Mencione-se que o artigo 401 do Código Civil estabelece os requisitos para a purga da mora pelo credor: ele terá que se oferecer para receber o pagamento sujeitando-se aos efeitos da mora até a data da oferta (artigo 401, inciso II, do Código Civil), além de reembolsar o devedor pelas despesas empregadas na conservação da coisa, bem como indenizá-lo por prejuízos eventualmente sofridos e decorrentes da mora do credor.

Por outro lado, na hipótese de a violação do dever de cooperação pelo credor tornar impossível ou extremamente onerosa, por parte do devedor, a entrega da prestação devida, entende-se que esse comportamento do credor deve acarretar as mesmas consequências do caso fortuito e da força maior, excluindo a responsabilidade do devedor nos moldes do artigo 393 do Código Civil, e liberando-o do vínculo obrigacional.

A esse respeito, Margarita Castilha Barea leciona que:

\footnotetext{
${ }^{346}$ LARENZ, Karl. Derecho de obligaciones. Tomo I. Trad. de Jaime Santos Briz. Madrid: Editora Revista de Derecho Privado. 1958. p. 375. Em tradução livre: "A conduta do credor também pode atrasar o cumprimento da obrigação ou acarretar para o devedor a impossibilidade de cumpri-la. Este atraso pode ter lugar quando o credor não aceita a oferta que lhe é oferecida no tempo e legar pactuados, impedindo, assim, que a prestação seja entregue oportunamente, ou faltando em outros casos a sua colaboração para o adimplemento, sem a qual o devedor não consegue atingi-lo. Em ambos os casos falamos de mora accipiendi ou mora do credor. Naturalmente o devedor não responde pelo atraso causado unicamente pela conduta do credor, de maneira que aquele estará livre das consequências da mora do devedor. Não obstante, continua obrigado à prestação, enquanto o seu cumprimento ainda for possível.”

${ }^{347}$ STJ, Resp n 857.299-SC, Rel. Ministro Paulo de Tarso Sanseverino, j. 03.05.2011.
} 
[...] el hecho del acreedor que incide sobre la prestación hasta hacerla definitivamente imposible determina la producción del supuesto de hecho de la imposibilitad sobrevenida inimputable, seguida de sus efectos típicos de extinción de la obligación y liberación del deudor. ${ }^{348}$

Para ilustrar, vale mencionar o caso em que, em litígio envolvendo empreiteira e dona da obra, o Tribunal de Justiça de São Paulo ${ }^{349}$ entendeu pela resolução do contrato por impossibilidade, sem culpa do devedor, no caso a empreiteira, tendo em vista que a dona da obra não providenciou licença na prefeitura, sem a qual a obra não poderia prosseguir.

Essa breve explanação sobre as consequências do descumprimento, pelo credor, do dever de colaboração será essencial no estudo do inadimplemento antecipado do contrato, pois permite concluir que o devedor não restará prejudicado caso o credor se omita em seu dever de cooperar e acarrete, com isso, uma situação de quebra antecipada.

${ }^{348}$ BAREA, Margarita Castilla. La imposibilidad de cumplir los contratos. LAEL: Dykinson. 2000. p. 83-85. No mesmo sentido: PONTES DE MIRANDA, Francisco Cavalcanti. Tratado de direito privado. tomo XXIII. São Paulo: Editora Revista dos Tribunais. p. 292. Em tradução livre: "o fato do credor que incide sobre a prestação até torná-la definitivamente impossível implica no inadimplemento inimputável ao devedor, com os efeitos típicos de extinção da obrigação e liberação do devedor."

${ }^{349}$ TJSP, Apelação no 9276980-70.2008.8.26.0000, Rel. Desembargador Amorim Cantuária, j. 03.08.2011. 


\section{INADIMPLEMENTO ANTECIPADO}

\subsection{Considerações gerais sobre o inadimplemento antecipado}

Em sua concepção tradicional e estática, entendia-se que, durante o lapso temporal que se inicia com a constituição da obrigação e se estende até o termo contratual, existiria um "vazio prestacional" em que o devedor não seria obrigado a nada, não podendo o credor exigir-lhe o cumprimento de nenhum dever ${ }^{350}$.

No entanto, na nova visão dinâmica e finalística de obrigação, pautada no princípio da boa-fé objetiva, as partes contratantes devem, ao longo da relação contratual, cooperar e realizar todos os atos necessários para que a prestação devida possa ser entregue no momento, no local e na forma pactuados no contrato. Os dois momentos (nascimento da obrigação e termo contratual), que até então eram repletos de um "vazio prestacional”, são conectados por uma série de atos que devem ser praticados por ambas as partes direcionados ao adimplemento ${ }^{351}$.

Determinados atos ou condutas - sejam decorrentes de deveres primários, secundários ou anexos - são exigidos de ambas as partes durante toda a relação contratual, notadamente do devedor, de maneira que o seu não cumprimento pode ser caracterizado como um inadimplemento da obrigação ${ }^{352}$. Isso porque, na medida em que a boa-fé exige

\footnotetext{
${ }^{350}$ MARTINS, Raphael Manhães. Inadimplemento antecipado: perspectiva para a sua aplicação no Direito brasileiro. Revista Forense, Rio de Janeiro, v. 391, ano 103, mai./jun. 2007. p. 207.

${ }^{351}$ MARTINS, Raphael Manhães. Inadimplemento antecipado: perspectiva para a sua aplicação no direito brasileiro. Revista Forense, Rio de Janeiro, v. 391, ano 103, mai./jun. 2007. p. 207.

${ }^{352}$ Sob essa nova perspectiva, a vontade do devedor de realizar os atos necessários ao adimplemento da obrigação não deve ser manifestada apenas no momento inicial e no momento em que a prestação se torna exigível. A vontade da parte de cumprir os deveres contratuais deverá se manifestar ao longo de toda a relação contratual por meio de atos ou condutas que evidenciem que ele está tomando as medidas necessárias para assegurar o adimplemento e a satisfação da prestação devida. Toda conduta ou manifestação de vontade contrária ao cumprimento da obrigação, a qualquer momento, é considerada contrária ao modo como deve exprimir-se constantemente a vontade do devedor e ao dever de colaboração que deve estar presente durante toda a relação obrigacional. Conforme assinala Anelise Becker, a concepção moderna de obrigação "induz a atribuir-se à vontade de adimplir uma importância que isoladamente, não é notada. Esta vontade é necessária à relação obrigacional porque a ela se liga o bom fim natural da obrigação; e é necessária constantemente, mesmo no tempo antecedente ao vencimento, a cada momento em que o devedor deva ter um determinado comportamento coerente com o escopo prático final da relação". BECKER, Anelise. A doutrina do adimplemento substancial no direito brasileiro e em perspectiva comparativista. Revista da Faculdade de Direito UFRGS, v. 9, Porto Alegre, Universidade Federal do Rio Grande do Sul, nov. 1993. p. 77.
} 
das partes um dever geral de colaboração, a violação antecipada deste dever poderá autorizar o inadimplemento antecipado do contrato, fazendo surgir a pretensão do credor à resolução do negócio jurídico ou a tomar outras providências.

Nas palavras de Cristiano de Sousa Zanetti,

[...] se o comportamento da parte desde logo comprometer de modo irremediável o cumprimento do programa obrigacional, carece de sentido exigir que o contratante inocente aguarde o advento do termo para tomar as providências necessárias à tutela do próprio interesse. Raciocinar em sentido contrário premiaria a conduta desleal, em detrimento do contratante probo. Semelhante inversão de valores, contudo, não encontra lugar no âmbito do Direito privado. ${ }^{353}$

Com efeito, vista a obrigação como um processo tendente ao adimplemento, pode ocorrer, principalmente nos contratos de longa duração, que o devedor declare que não cumprirá, ou demonstre por seu comportamento que não honrará sua prestação, o que permitirá que o credor repute o contrato inadimplido antes do seu termo ${ }^{354}$. A tais situações se costuma designar "inadimplemento antecipado"355, "quebra antecipada do contrato"356, ou "inadimplemento anterior ao termo",357.

\footnotetext{
353 ZANETTI, Cristiano de Souza. Inadimplemento Antecipado da Obrigação Contratual. In: CELLI JUNIOR, Umberto; BASSO, Maristela; AMARAL JÚNIOR, Alberto do (Coord). Arbitragem e comércio internacional: estudos em homenagem a Luiz Olavo Baptista. São Paulo: Quartier Latin. 2013. p. 330. Conforme assinala Anderson Schreiber, "independentemente da tese que ora se propõe, o certo é que, seja na hipótese de impossibilidade, seja na de improbabilidade do cumprimento, parece injustificável conservar o credor em estado de absoluta paralisia até o vencimento da obrigação, preservando um verdadeiro vácuo na relação obrigacional, que, embora regularmente constituída, nenhum efeito produz até que se verifique a sua já anunciada frustração". SCHREIBER, Anderson. A tríplice transformação do adimplemento. Adimplemento substancial, inadimplemento antecipado e outras figuras. Revista Trimestral de Direito Civil. Rio de Janeiro, v. 32, out./dez 2007, p. 13.

${ }^{354}$ A doutrina moderna rompeu com a regra de que somente se pode considerar descumprida a obrigação com o advento do termo do contrato, de modo que a intenção manifestada de uma das partes de não cumprir o contrato ou um comportamento neste sentido são considerados suficientes para que se considere desobrigado o outro contratante. Nesse sentido: MARTINS. Guilherme Magalhães. Inadimplemento antecipado do contrato. Revista Trimestral de Direito Civil. Rio de Janeiro, v. 36, out/dez 2008, p. 82.

${ }^{355}$ MARTINS, Raphael Manhães. Inadimplemento antecipado: perspectiva para a sua aplicação no direito brasileiro. Revista Forense, Rio de Janeiro, vol. 391, ano 103, mai./jun. 2007, p. 208.

${ }_{356}$ AGUIAR JR., Ruy Rosado. Extinção dos contratos por incumprimento do devedor (resolução). Rio de Janeiro: Aide. 1991. p. 126-127.

${ }^{357}$ TERRA, Aline de Miranda Valverde. Inadimplemento anterior ao termo. Rio de Janeiro: Renovar. 2009. p. 122-123.
} 
É o caso, por exemplo, de um contrato de empreitada, na construção civil, em que se ajusta a entrega de um prédio de apartamentos de 15 (quinze) andares a ser construído em 24 (vinte e quatro) meses e, transcorridos 14 (quatorze) meses, a obra sequer começou a ter as suas fundações escavadas ${ }^{358}$.

Pode-se cogitar da situação em que duas empresas celebram uma parceria para desenvolver um determinado produto tecnológico nos próximos 2 (dois) anos. Na hipótese de uma das empresas descobrir que a outra está criando, em paralelo e secretamente, um produto equivalente, utilizando-se do mesmo sistema projetado para o produto objeto da parceria, haveria uma grave violação ao dever de lealdade imposto pela boa-fé.

Também pode ser mencionado o caso do importador de mercadoria que deve solicitar autorização específica perante órgão de fiscalização (IBAMA ou Ministério da Defesa, por exemplo) para poder trazer determinado produto para o país, mas não o faz dentro do prazo previsto contratualmente ou necessário para a importação da mercadoria no termo previsto no contrato ${ }^{359}$.

Outra situação que merece atenção é a dos contratos cuja prestação se desenvolve ao longo de grande período de tempo, o objeto da prestação é desenvolvido em fases, mas cujo produto somente é entregue ao final, como acontece com os Turnkey Construction Contracts, muito utilizados para obras pesadas como a construção de usinas hidrelétricas. Nesses casos, é possível a caracterização de inadimplemento antecipado caso o devedor atrase demasiadamente as primeiras fases do projeto e se demonstre inviável a entrega da obra no prazo pactuado ${ }^{360}$.

Em todas essas situações, o atraso nos atos preparatórios e nos atos de execução, a infringência de deveres secundários de prestação ou, ainda, dos deveres

\footnotetext{
${ }^{358}$ MARTINS-COSTA, Judith. Comentários ao novo Código Civil. Rio de Janeiro: Forense. 2004. p. 156.

359 O exemplo é de MARTINS, Raphael Manhães. Inadimplemento antecipado: perspectiva para a sua aplicação no Direito brasileiro. Revista Forense, Rio de Janeiro, v. 391, ano 103, mai./jun. 2007, p. 209.

${ }^{360}$ MARTINS, Raphael Manhães. Inadimplemento antecipado: perspectiva para a sua aplicação no Direito brasileiro. Revista Forense, Rio de Janeiro, v. 391, ano 103, mai./jun. 2007, p. 209.
} 
laterais pode configurar um inadimplemento antecipado do contrato e, consequentemente, acarretar a sua resolução ou a tomada de outras medidas pertinentes ${ }^{361}$.

Em linhas gerais, o inadimplemento antecipado da obrigação pode ser conceituado como o inadimplemento que ocorre quando uma das partes da relação obrigacional, antes do termo contratual ou do momento em que deveria executar uma determinada prestação, renuncia ao contrato ou coloca-se em posição que torne impossível ou inútil o cumprimento da obrigação no prazo avençado entre as partes ${ }^{362}$.

Com efeito, a figura do inadimplemento antecipado exige: a presença de uma grave violação a um dever obrigacional antes do termo do contrato, caracterizadora de “justa causa" à resolução ou à tomada de outra medida; a certeza ou uma probabilidade próxima à certeza de que o cumprimento da obrigação não se dará até o vencimento; e a declaração do devedor de que não irá cumprir, ou o comportamento do devedor que indique que ele não irá adimplir ou que o cumprimento se tornou impossível ${ }^{363}$.

Extraem-se da definição acima os principais elementos do instituto do inadimplemento antecipado: (i) ele consiste em uma forma de inadimplemento; (ii) ocorre, necessariamente, antes do termo da prestação devida; (iii) esta forma de inadimplemento pode manifestar-se seja por uma renúncia (expressa ou tácita) ao cumprimento da obrigação, ou pelo fato do obrigado colocar-se em posição que torna o adimplemento

\footnotetext{
${ }^{361}$ De acordo com Jorge Cesa Ferreira da Silva, o inadimplemento antecipado do contrato pode decorrer tanto da infringência de deveres principais como secundários de prestação, como ainda dos deveres laterais, anexos ou instrumentais de conduta, configurando, nesta última hipótese, a violação positiva do contrato SILVA, Jorge Cesa Ferreira da. A boa-fé e a violação positiva do contrato. Rio de Janeiro: Renovar. 2002. p. 261.

${ }^{362}$ MARTINS, Raphael Manhães. Inadimplemento antecipado: perspectiva para a sua aplicação no Direito brasileiro. Revista Forense, Rio de Janeiro, v. 391, ano 103, mai./jun. 2007. p. 208. Gustavo Tepedino afirma que o inadimplemento antecipado ocorre "quando o devedor declara que não pode ou não quer adimplir, ou quando nada aparelhou com destino ao cumprimento da obrigação, tornando certo o inadimplemento". TEPEDINO, Gustavo. BARBOZA, Heloisa Helena. MORAES, Maria Celina Bodin de. Código Civil interpretado conforme a Constituição da República. v. I, 2. ed. rev. e atual. Rio de Janeiro: Renovar. 2007. p. 699.

363 MARTINS-COSTA, Judith H. A recepção do incumprimento antecipado no direito brasileiro: configurações e limites. São Paulo: Revista dos Tribunais. v. 885. p. 34.
} 
impossível; e (iv) ele deve ser provocado por ato próprio do devedor, de forma incontroversa e definitiva ${ }^{364}$.

Ruy Rosado Aguiar Junior assim sintetiza o conceito de inadimplemento antecipado:

É possível o inadimplemento antes do tempo, se o devedor pratica atos nitidamente contrários ao cumprimento ou faz declarações expressas nesse sentido, acompanhadas de comportamento efetivo, contra a prestação, de tal sorte que se possa deduzir, conclusivamente, dos dados objetivos existentes, que não haverá cumprimento. Se esta situação se verificar, o autor pode propor a ação de resolução. O incumprimento antecipado ocorrerá sempre que o devedor, beneficiado com um prazo, durante ele pratique atos que, por força da natureza ou da lei, faça impossível o futuro cumprimento.

Além da impossibilidade, o incumprimento antecipado pode resultar de conduta contrária do devedor, por ação (venda do estoque, sem perspectiva de reposição), ou omissão (deixar de tomar as medidas prévias indispensáveis para a prestação), ou de declaração do devedor expressa no sentido de que não irá cumprir a obrigação. ${ }^{365}$

O Código Civil brasileiro, ao contrário de outros ordenamentos jurídicos estrangeiros integrantes da civil law, não dispõe de artigo específico a respeito do inadimplemento antecipado. De outra parte, as tradicionais noções de objeto da obrigação, adimplemento e inadimplemento previstas no Código Civil brasileiro acabam por se colocar como obstáculos à aplicação do instituto do inadimplemento antecipado e à correta identificação dos seus fundamento e efeitos.

Com efeito, a análise meramente formal do termo de adimplemento presente no Código Civil se apresenta como barreira à adequada aplicação da teoria, uma vez que concebe a prestação a termo como inexigível antes do prazo pactuado, independentemente de qualquer análise funcional do termo ${ }^{366}$. Daí a regra prevista no artigo 939 do Código Civil, segundo a qual "o credor que demandar o devedor antes de vencida a dívida, fora dos casos em que a lei o permita, ficará obrigado a esperar o tempo que faltava para o

\footnotetext{
${ }^{364}$ MARTINS, Raphael Manhães. Inadimplemento antecipado: perspectiva para a sua aplicação no Direito brasileiro. Revista Forense, Rio de Janeiro, v. 391, ano 103, mai./jun. 2007, p. 208.

${ }_{365}$ AGUIAR JR., Ruy Rosado. Extinção dos contratos por incumprimento do devedor (resolução). Rio de Janeiro: Aide. 1991. p. 126-127.

${ }^{366}$ TERRA, Aline de Miranda Valverde. Inadimplemento anterior ao termo. Rio de Janeiro: Renovar. 2009. p. 123.
} 
vencimento, a descontar os juros correspondentes, embora estipulados, e a pagar as custas em dobro".

Desta maneira, o reconhecimento do inadimplemento antecipado depende de uma releitura dos institutos clássicos do direito das obrigações, que visualize a obrigação em seu caráter dinâmico, complexo e finalístico e atribua mais importância ao comportamento das partes, que sempre deverá ser norteado pelo princípio da boa-fé objetiva e da confiança entre os contratantes. Nesse sentido se posiciona Judith-Martins Costa:

\footnotetext{
Entre nós embora a resposta fosse majoritariamente negativa, na vigência do Código de 1916 (quanto ao menos por sequer se aventar sobre o assunto), certa doutrina e alguns julgados já vinham apontando à possibilidade de ultrapassagem da norma de clausura hoje posta no art. 939 (correspondente ao art. 1.530 do Código de 1916), a partir da visualização da complexidade da relação obrigacional, principalmente quando se tratar de obrigação duradoura, e em razão da potencialidade do princípio da boa-fé objetiva. ${ }^{367}$
}

De acordo com Araken de Assis, haveria ainda obstáculos processuais à aceitação do instituto do inadimplemento antecipado pelo direito brasileiro ${ }^{368}$. O primeiro desses obstáculos seria o artigo 580 do Código de Processo Civil ${ }^{369}$, que exige como requisito para o ajuizamento da ação de execução o inadimplemento da prestação. A crítica, contudo, não se sustenta. Conforme observa Humberto Theodoro Júnior, “o inadimplemento é figura típica do direito material. O que toca ao direito processual não é a sua conceituação, mas definir quando o inadimplemento se torna causa justificadora do processo de execução" 370 .

Assim, entendemos que, se a noção de inadimplemento do direito civil brasileiro abranger o inadimplemento antecipado das obrigações - como de fato abrange, se adotada uma concepção dinâmica e funcional das obrigações -, o dispositivo processual

\footnotetext{
${ }^{367}$ MARTINS-COSTA, Judith. Comentários ao novo Código Civil. Rio de Janeiro: Forense. 2004. p. 157.

368 ASSIS, Araken de. Resolução do contrato por inadimplemento. 4. ed. rev. e atual. São Paulo: Editora Revista dos Tribunais. 2004. p. 107.

369 "Art. 580. A execução pode ser instaurada caso o devedor não satisfaça a obrigação certa, líquida e exigível, consubstanciada em título executivo."

${ }^{370}$ THEODORO JUNIOR, Humberto. A reforma da execução do título extrajudicial: Lei no 11.382 , de 06 de dezembro de 2006. Rio de Janeiro: Forense. 2007. p. 14-15.
} 
incide na hipótese; caso contrário, não lhe é aplicado. Conforme observa Aline Terra, "a rigor, portanto, o art. 580 não representa entrave à aceitação do instituto no direito brasileiro, mas pode apenas limitar seus efeitos, consoante a abrangência atribuída ao conceito de inadimplemento",371.

Araken de Assis aponta que o segundo obstáculo imposto à aplicação do inadimplemento antecipado estaria no artigo 618, inciso III, do Código de Processo Civil $^{372}$, que reputa nula a execução instaurada antes do advento do seu termo. No entanto, o próprio autor adverte que o mencionado dispositivo legal cria óbice à demanda de cumprimento, e não aos demais efeitos decorrentes do inadimplemento antecipado (com o que não concordamos, conforme se abordará no terceiro capítulo). ${ }^{373}$

De qualquer maneira, a verdade é que o instituto do inadimplemento antecipado foi objeto de poucas obras específicas na doutrina, razão que nos motivou a realizar o presente estudo a fim de contribuir com a sua disseminação no ambiente jurídico brasileiro e a sua aplicação pelos Tribunais pátrios.

Se for possível traçar a linha evolutiva a respeito da aceitação do instituto do inadimplemento antecipado pela doutrina brasileira, talvez se deva a Serpa Lopes, ainda na década de 1950, uma das primeiras manifestações favoráveis ${ }^{374}$. Na década de 1960, João Baptista Villela, em comunicação ao Sétimo Congresso Internacional de Direito Comparado, se pronunciou de maneira favorável à figura no direito brasileiro, caracterizando-a como situação de pré-inadimplência ${ }^{375}$. Na primeira obra dedicada

\footnotetext{
${ }^{371}$ TERRA, Aline de Miranda Valverde. Inadimplemento anterior ao termo. Rio de Janeiro: Renovar. 2009. p. 125 .

372 "Art. 618. É nula a execução: III. Se instaurada antes de se verificar a condição ou decorrido o termo, nos casos do art. 572."

373 ASSIS, Araken de. Resolução do Contrato por Inadimplemento. 4. ed. rev. e atual. São Paulo: Editora Revista dos Tribunais. 2004. p. 107-109.

${ }^{374}$ Serpa Lopes afirma que: "Não dispomos, na verdade, de um dispositivo legal que nos facilite uma interpretação por analogia, como acontece no Direito positivo italiano. Cremos, entretanto, que isso não é obstáculo à aplicação de um princípio que não vulnera a estrutura que se possa considerar oposta a essa forma de vencimento antecipado." SERPA LOPES, Miguel Maria. Exceções substanciais: exceção de contrato não cumprido (exceptio non adimpleti contractus). Rio de Janeiro: Freitas Bastos. 1959, p. 293.

375 VILLELA, João Baptista. Sanção por inadimplemento contratual antecipado. Subsídios para uma teoria intersistemática das obrigações. Belo Horizonte. 1966. p. 6.
} 
exclusivamente ao tema na doutrina brasileira, Fortunato Azulay defendeu categoricamente a admissibilidade do adimplemento antecipado:

\begin{abstract}
A esse teor, e do que nos capítulos anteriores ficou explicitado, se poderá afirmar que basta admitir a noção de pré-inexecução ou pré-inadimplência (anticipatory breach) como categoria jurídica de inexecução contratual, para que se possa sistematizar a matéria em face do direito escrito [...]. Não se poderá deixar de admitir em nosso direito, omisso embora quanto às consequências do rompimento unilateral antecipado do contrato, a aplicação criteriosa da doutrina naqueles dois casos excepcionais referidos por Mosco e Serpa Lopes e que constituem, de um modo geral, as hipóteses que originaram a formação de doutrina nos tribunais ingleses e americanos. ${ }^{376}$
\end{abstract}

Aos poucos a questão do inadimplemento antecipado começa a ganhar espaço dentre as publicações mais recentes. Uma nova geração de juristas ${ }^{377}$ começa a se dedicar à análise do tema sob perspectiva renovada e a defender a aplicação do inadimplemento antecipado no direito brasileiro. Nessa esteira, a V Jornada de Direito Civil do Conselho de Justiça Federal/STJ, realizada em maio de 2012, aprovou o Enunciado 437, segundo o qual "A resolução da relação jurídica contratual também pode decorrer do inadimplemento antecipado". No entanto, apesar dos esforços no sentido de defender a aplicação do inadimplemento antecipado no direito brasileiro, a atenção que lhe é dedicada está longe de ser apropriada à sua perfeita compreensão e identificação de fundamentos e efeitos.

A jurisprudência brasileira começou a aplicar nas últimas décadas a figura do inadimplemento antecipado ${ }^{378}$, na esteira do leading case julgado pelo Tribunal de Justiça

${ }^{376}$ AZULAY, Fortunato. Do inadimplemento antecipado do contrato. Rio de Janeiro: Editora Brasília/Rio, 1977. p. 112.115-116.

${ }^{377}$ Dedicam-se ao estudo: BECKER, Anelise. Inadimplemento antecipado do contrato. Revista de Direito do Consumidor, São Paulo: Revista dos Tribunais, n. 12, 1994; DUARTE, Adriana Dardengo. A quebra do contrato por repúdio antecipado no direito brasileiro: proposta de aplicação de uma teoria. Dissertação apresentada ao curso de mestrado da Universidade Federal de Minas Gerais, 2006; MARTINS, Raphael Manhães. Inadimplemento antecipado: perspectiva para a sua aplicação no direito brasileiro. Revista Forense, Rio de Janeiro, v. 391, ano 103, mai./jun. 2007. TERRA, Aline de Miranda Valverde. Inadimplemento anterior ao termo. Rio de Janeiro: Renovar. 2009. ZANETTI, Cristiano de Souza. Inadimplemento Antecipado da Obrigação Contratual. In: CELLI JUNIOR, Umberto; BASSO, Maristela; AMARAL JÚNIOR, Alberto do (Coord). Arbitragem e comércio internacional: estudos em homenagem a Luiz Olavo Baptista. São Paulo: Quartier Latin. 2013.

${ }^{378}$ No último capítulo serão analisados alguns casos de inadimplemento antecipado julgados pelos Tribunais brasileiros. 
do Rio Grande do Sul ${ }^{379}$. Em meados de 1977, Nilo Antônio Peruzzo celebrou dois contratos em conta de participação em empreendimento a ser realizado pelo Centro Médico Hospital de Porto Alegre Ltda., os quais ofereciam, além da participação nos lucros da sociedade, atendimento médico-hospitalar gratuito ao cotista e sua família mediante o pagamento de certa quota fixa, a ser dividida em parcelas mensais.

Após a celebração do segundo contrato, o Sr. Nilo decidiu averiguar o andamento das obras e, para a sua surpresa, o terreno em que a construção do hospital seria realizada sequer havia sido adquirido pelo Centro Médico. Diante de tal situação, o Sr. Nilo suspendeu o pagamento das parcelas mensais e, em contrapartida, o Centro Médico protestou duas notas promissórias por ele assinadas. Em face do inadimplemento do Centro Médico, o Sr. Nilo ajuizou ação visando à resolução do contrato, bem como à nulidade das notas promissórias a ele vinculadas, devolução dos valores recebidos e perdas e danos.

Em primeiro grau de jurisdição, o juiz - baseando-se em uma visão estática, formalista e estrutural de obrigação - entendeu não restar caracterizado o inadimplemento do Centro Médico em virtude da inexistência de prazo fixado para o início e o término da construção do hospital. Em sede de apelação, o então Desembargador Athos Gusmão Carneiro decidiu pela procedência da demanda, nos seguintes termos:

\begin{abstract}
A Dra. Pretora refere que no contrato não estava previsto nenhum prazo para o Centro "construir, instalar e operar estabelecimento hospitalar na cidade de Porto Alegre". Todavia, considero evidente, como bem alega o apelante, que isso não significa goze um dos contratantes da faculdade de retartar ad infinitum o cumprimento das suas obrigações, e o outro seja obrigado a adimplir as suas com pontualidade, sob pena do protesto dos títulos. A sentença esquece toda a comutatividade contratual. Vejo, aqui, caso de completo inadimplemento por parte de um dos contratantes. Já transcorreram mais de 5 anos e o Centro Médico Hospitalar existe apenas de jure. De fato, esta sociedade, de objetivos tão ambiciosos e capital pequeníssimo, simplesmente não existe mais. Citada editalmente, foi revel. O hospital permanece no campo das miragens, e assim as demais vantagens prometidas aos subscritores. ${ }^{380}$
\end{abstract}

\footnotetext{
379 Confiram-se os comentários de Anelise Becker sobre a mencionada decisão: BECKER, Anelise. Inadimplemento antecipado do contrato. Revista de Direito do Consumidor, São Paulo: Revista dos Tribunais, n. 12, 1994.

${ }^{380}$ TJRS, Apelação Cível no 582000378, $1^{\text {a }}$ Câmara Cível, Rel. Desembargador Athos Gusmão Carneiro, j. 08.02.1983. Acórdão publicado na Revista de Jurisprudência do Tribunal de Justiça do Rio Grande do Sul, n. 97, abril de 1983 , p. 397 et seq.
} 
Apesar da ausência de dispositivo específico no Código Civil, o inadimplemento antecipado não é figura completamente desconhecida na legislação brasileira. No âmbito do direito administrativo, há a expressa possibilidade da Administração Pública resolver o contrato sempre que a demora no cumprimento permitir antever a impossibilidade de se concluir a obra, o serviço ou o fornecimento no prazo ajustado, conforme se observa da redação do artigo 78, inciso III, da Lei no 8.666/1993 (Lei das Licitações e Contratos Administrativos):

Art. 78. Constituem motivo para a rescisão do contrato:

III - a lentidão do seu cumprimento, levando a Administração a comprovar impossibilidade da conclusão da obra, do serviço ou do fornecimento, nos prazos estipulados.

A respeito do mencionado dispositivo legal da Lei das Licitações e Contratos Administrativos, a doutrina afirma que ele exige que a Administração Pública "se antecipe à consumação do inadimplemento, verificando, pelo ritmo dos trabalhos do contratado, que não haverá a entrega da prestação no tempo marcado pelo contrato" ${ }^{381}$. Em outras palavras, o referido dispositivo impõe o poder-dever da Administração Pública rescindir contratos administrativos quando se caracterizar uma situação de inadimplemento antecipado das obrigações.

É esse o panorama geral acerca do instituto do inadimplemento antecipado no direito brasileiro. A seguir será feita uma breve apresentação sobre as figuras do anticipatory breach of contract, da common law, e da disciplina do inadimplemento antecipado em outros países que adotam o sistema da civil law e em tratados internacionais, para, enfim, passar-se à análise do adimplemento antecipado no direito brasileiro a fim de se identificar seus suportes de aplicação, âmbito de incidência, fundamento, limites e efeitos.

\subsection{O inadimplemento antecipado no direito estrangeiro e internacional}

381 PEREIRA JUNIOR, Jessé Torres. Comentários à Lei de Licitações e Contratações da Administração Pública. 7. ed. atual e ampl. Rio de Janeiro: Renovar. 2007. p. 777. 
A maioria dos doutrinadores nacionais ${ }^{382}$ afirma que a origem do inadimplemento antecipado remontaria à anticipatory breach of contract, da common $\operatorname{law}^{383}$. Nesse sentido, em obra precursora sobre o tema, Fortunato Azulay sustenta que o instituto brasileiro do inadimplemento antecipado seria uma adaptação da teoria da anticipatory breach of contract ${ }^{384}$.

No sistema da common law, denomina-se "quebra do contrato" (breach of contract) o não cumprimento inescusável de deveres exigíveis. Alguns deveres são impostos por lei a despeito da vontade das partes e as obrigam à observância de determinadas condutas. Dentre tais deveres está o de não repudiar (repudiate) o contrato antes da data pactuada para o cumprimento da obrigação. O repúdio (repudiation) é considerado uma das formas de quebra do contrato, pelo qual uma das partes manifesta, por palavras ou conduta, que não irá cumprir a prestação devida. O repúdio anterior ao termo configura a violação de um dever legal, e, portanto, constitui uma quebra antecipada do contrato (anticipatory breach of contract) ${ }^{385}$.

O repúdio ao contrato e à quebra antecipada do contrato é explicado da seguinte forma por P. S. Atiyah:

[...] Any intimation, whether by words or by conduct, that a party declines to continue with the contract, is a repudiation if the result is very likely to be to deprive the innocent party of substantially the whole benefit of the contract. [...] A repudiation by one party may occur before the time for performance has arrived. Such a repudiation is called an anticipatory breach, and it gives the

\footnotetext{
${ }^{382}$ Neste sentido: AZULAY, Fortunato. Do inadimplemento antecipado do contrato. Rio de Janeiro: Editora Brasília/Rio. 1977. p. 111-112; SILVA, Clóvis do Couto e. O princípio da boa-fé no direito brasileiro e no direito português; CAETANO, Marcello et al. Estudos de direito civil brasileiro e português (I Jornada lusobrasileira de direito civil). São Paulo: Revista dos Tribunais. 1980. p. 47; MARTINS, Raphael Manhães. Inadimplemento antecipado: perspectiva para a sua aplicação no Direito brasileiro. Revista Forense, Rio de Janeiro, v. 391, ano 103, mai./jun. 2007, p. 164. Em sentido contrário, Jorge Cesa Ferreira da Silva entende que o instituo do inadimplemento antecipado procede do Erfüllungsverweigerung do direito alemão. SILVA, Jorge Cesa Ferreira da. A boa-fé e a violação positiva do contrato. Rio de Janeiro: Renovar. 2002. p. 261.

${ }^{383}$ Destaque-se que não constitui objetivo desse trabalho resolver a origem do instituto do inadimplemento antecipado do contrato. A solução dessa questão demandaria profundo estudo comparado sobre o tema, e esta não é a sede própria para tamanha empreitada. A finalidade deste item consiste apenas em apresentar, em linhas gerais, o tratamento conferido pelo direito estrangeiro e internacional sobre o tema.

${ }^{384}$ AZULAY, Fortunato. Do inadimplemento antecipado do contrato. Rio de Janeiro: Editora Brasília/Rio. 1977. p. 111-112.

${ }^{385}$ TERRA, Aline de Miranda Valverde. Inadimplemento anterior ao termo. Rio de Janeiro: Renovar. 2009. p. 140-141.
} 
innocent party the option of treating the contract as terminated at once and suing for damages immediately if he chooses or, alternatively, of waiting until the time of performance has arrived, and then again calling on the other party to perform.

A teoria do anticipatory breach of contract foi enunciada pela primeira vez em 1853, no leading case Hochster vs. De la Tour. Em abril de 1852, Hochster, mensageiro britânico, foi contratado para prestar seus serviços de recados a De la Tour durante uma viagem de três meses à Europa, que teria início no primeiro dia de junho daquele ano ${ }^{387}$. Antes disso, todavia, a De la Tour manifestou-se no dia 12 de maio daquele ano no sentido de que não precisaria mais dos serviços de Hochster, sem o indenizar pelo rompimento do contrato anteriormente celebrado entre as partes. Inconformado, Hochster foi a juízo em 22 de maio pleiteando indenização por perdas e anos, uma vez que entendeu o comportamento de la Tour como verdadeira violação do contrato. É importante destacar que a ação judicial foi ajuizada dez dias antes do termo contratual.

Foi justamente por essa razão que, na resposta que apresentou à demanda, De la Tour alegou que a ação carecia de substrato a lhe dar ensejo, sob a justificativa de que seria inconcebível a postulação de quebra contratual quando o pactuado ainda não era exigível. Outrossim, De la Tour argumentou que a sua prévia manifestação encaminhara-se no sentido de "uma oferta para extinguir a relação obrigacional, de modo a liberar o autor de se manter disponível e pronto a cumprir sua prestação" ${ }^{388}$. Em outras palavras, De la Tour sustentou que caberia a Hochster aceitar a rescisão ou permanecer à sua disposição até o advento do termo contratual.

\footnotetext{
${ }^{386}$ ATIYAH, P. S.. An Introduction to the Law of Contract. Third Edition Clarendon Law Series. Oxford: Oxford University Press. 1981. p. 297-298. Em tradução livre: “Qualquer manifestação, por palavras ou conduta, de que uma parte se recusa a continuar com um contrato, é um repúdio se daí resultar que é provável que a parte inocente será substancialmente privada de todo o benefício do contrato. [...] O repúdio de uma parte pode ocorrer antes do cumprimento do contrato. Tal repúdio é chamado de quebra antecipada e confere à parte inocente a opção de considerar o contrato rescindido e pleitear imediatamente indenização por perdas e danos, se ela escolher, ou, alternativamente, aguardar o prazo de cumprimento da obrigação e posteriormente requerer que a outra parte cumpra a obrigação."

387 Para maiores detalhes sobre o caso remete-se a CORBIN, Arthur Linton. Corbin on Contracts. New Haven: West Publishing Co. 1952. p. 142.

388 TERRA, Aline de Miranda Valverde. Inadimplemento anterior ao termo. Rio de Janeiro: Renovar. 2009. p. 142.
} 
Ao decidir o caso, Lord Chief Justice Campbell afirmou que as alternativas referidas por De la Tour não se configuravam viáveis. Não poderia ser considerado justo o mensageiro arcar com a extinção do contrato sem qualquer indenização, muito menos se engessar no aguardo do termo. Lord Campbell entendeu que fazer o mensageiro aguardar o decurso do termo seria incoerente, uma vez que já era sabido que o contrato não se realizaria. Portanto, o juiz resolveu dar razão ao mensageiro, admitindo que a manifestação de la Tour configurou um inadimplemento antecipado do contrato ${ }^{389}$.

Esse é considerado pela doutrina como o primeiro caso no qual um tribunal admitiu a teoria do inadimplemento antecipado do contrato ${ }^{390}$. A partir desse leading case inglês ficou estabelecido que o repúdio ao contrato autoriza a parte inocente a ajuizar ação de ressarcimento por perdas e danos imediatamente, ou seja, antes do advento do termo de

\footnotetext{
${ }^{389}$ Segue trecho da decisão do Lord Campbell que trata da questão: "It should be held that, upon a contract to do an act on a future day, a renunciation on the contract by one party dispenses with a condition to be performed in the meantime by the other, there seems no reason for requiring that order to wait till the say arrives before seeking this remedy by action: and the only ground on which the condition can be dispensed with seems to be, that the renunciation may be treated as a breach of the contract. Upon the whole, we think that the declaration is in this case sufficient." Em tradução livre: "Deve-se considerar que, em um contrato a termo, a renúncia de uma das partes dispensa a outra de cumprir a sua obrigação nesse mesmo tempo, haja vista que não há razão para exigir que essa providência observe o termo para que seja identificado um remédio, e a única razão que parece existir para se dispensar a observação do prazo parece ser que a renúncia pode ser tratada como descumprimento do contrato. No todo, entendemos que a declaração neste caso é suficiente."

${ }^{390}$ A esse respeito, Robert E. Scott e Jody S. Kraus afirmam: "at early common law, the requirement that a party must breach to trigger the other party's duty to mitigate meant that neither party could be required to adjust to post-formation events until after the time for performance. This was because, on the classical common law view, a party could not be in breach of a duty until that party's duty matured and he failed to discharge it. In Hochster, however, the common law made an exception to this rule. A promisor could effectively declare a breach before the time for performance by anticipatorily repudiating his contract. Likewise, if an event occurring prior to the time for performance rendered it impossible for a promisor to perform by that deadline, the promise could use the doctrine of anticipatory repudiation to declare the promisor presently in breach of agreement." SCOTT, Robert E. and KRAUS, Jody S. Contract law and theory. 4th ed. LexisNexis. 2007. p. 815. Em tradução livre: "nos primórdios da common law, a exigência de que uma parte deveria descumprir o contrato para que fosse acionado o gatilho do dever de mitigar da outra parte significava que nenhuma das partes poderia ajustar eventos posteriores à formação do contrato até o termo do contrato. Isso se deu em razão da ótica clássica da common law, em que uma parte não poderia descumprir com as suas obrigações até o vencimento dessa obrigação sem que a parte tivesse conseguido cumpri-la. Em Hochster, entretanto, a common law fez uma exceção a essa regra. O promitente poderia efetivamente declarar descumprimento das suas obrigações antes do termo do contrato por ter antecipadamente descumprido o seu contrato. Igualmente, se um evento ocorresse previamente ao termo do contrato e em razão de tal evento fosse considerado impossível que o promitente cumprisse com as suas obrigações até aquele prazo, poderia ser aplicada a teoria do inadimplemento antecipado para declarar que o promitente violou o acordo."
} 
adimplemento, além de dispensá-la de cumprir a sua obrigação. Outros $\operatorname{casos}^{391}$ se lhe sucederam, sedimentando em jurisprudência inglesa e norte-americana a acolhida do inadimplemento antecipado ${ }^{392}$.

A doutrina anglo-saxônica reconheceu amplamente a possibilidade de o contrato ser considerado inadimplido antecipadamente quando o devedor violar o dever legal de não repudiar, revelando por atos ou palavras que não poderá ou desejará adimplir a obrigação no prazo avençado ${ }^{393}$, construindo a teoria do anticipatory breach of contract, que pode ser assim sintetizada:

It is now the generally prevailing rule in both England and the United States that a definite and unconditional repudiations of the contract by the party thereto, communicated to the other, is a breach of the contract, creating an immediate right of action and other legal effects, even though it takes place long before the time prescribed for the promised performance and before conditions specified in the promise have ever occurred. ${ }^{394}$

No mesmo sentido de manifesta E Hunter Taylor Jr.:

An anticipatory breach of contract occurs when a "definitive and unequivocal" repudiation of intent to perform a "substantial" part of the contract at the date is made, either expressly or impliedly, prior to the time for performance and is

\footnotetext{
${ }^{391}$ Nesse sentido: "Importante mencionar que, depois de Hochster v. De la Tour, outros julgados também contribuíram de maneira substancial para a construção, nos países do Common Law, do instituto do 'anticipatory breach of contract', tais como Frost v. Knight, Equitable Trust Co. v. Western Pacific R. Co. e Tenavision In. V. Neuman.” ANDRADE, Luis Tomás Alves de. O Inadimplemento Antecipado do Contrato no Direito Brasileiro. R. EMERJ, Rio de Janeiro, v. 14, n. 56, p. 145-172, out-dez., 2011. p. 150.

${ }^{392}$ Nesse sentido: “A exceção de considerar o repúdio ao cumprimento da prestação por uma das partes como inadimplemento antecipado, possibilitando a rescisão do contrato com a indenização à outra parte das perdas e danos consequentes, teve consagração ampla na jurisprudência norte-americana, muito embora se levantem dúvidas e impugnações na gama infinita das hipóteses ocorrentes." AZULAY, Fortunato. Do inadimplemento antecipado do contrato. Rio de Janeiro: Editora Brasília/Rio. 1977. p. 102-103.

${ }^{393}$ Nesse sentido: "Desde meados do século passado surgiu na Inglaterra a chamada doutrina do anticipatory breach do contrato, pela qual veio a ficar consagrada em outros sucessivos julgados, também nos EUA, que, se um dos contratantes revela, por atos ou palavras peremptórias e inequívocas, a intenção de não cumprir a sua prestação, diferida a tempo certo, pode a outra parte considerar esse comportamento como inadimplência contratual." AZULAY, Fortunato. Do inadimplemento antecipado do contrato. Rio de Janeiro: Editora Brasília/Rio. 1977. p. 101.

${ }^{394}$ CORBIN, Arthur Linton. Corbin on Contracts. New Haven: West Publishing Co., 1952. Em tradução livre: "O atual entendimento majoritário na Inglaterra e nos Estados Unidos é de que um repúdio definitivo e incondicional ao contrato feito por uma parte, que tenha sido comunicado à outra parte, é uma quebra do contrato, criando um direito de agir imediato dentre outros efeitos legais, ainda que demorasse muito tempo até que fosse atingido o termo contratual para o adimplemento e antes que as condições estipuladas contratualmente tivessem se verificado."
} 
communicated, either directly or indirectly, to the party on the other side of the contract. $^{395}$

A Inglaterra não legislou sobre o tema do inadimplemento antecipado. Em 1952, os Estados Unidos, que já possuíam um considerável número de precedentes a respeito do inadimplemento antecipado do contrato, positivaram a matéria por meio do §2610 do Uniform Commercial Code - o Código Comercial Americano ${ }^{396}$, nos seguintes termos:

\section{$\S 2-610$. Anticipatory Repudiation.}

When either party repudiates the contract with respect to a performance not yet due the loss of which will substantially impair the value of the contract to the other, the aggrieved party may

(a) for a commercially reasonable time await performance by the repudiating party; or

(b) resort to any remedy for breach (Section 2-703 or Section 2-711), even though he has notified the repudiating party that he would await the latter's performance and has urged retraction; and

(c) in either case suspend his own performance or proceed in accordance with the provisions of this Article on the seller's right to identify goods to the contract notwithstanding breach or to salvage unfinished goods (Section 2-704). ${ }^{397}$

A partir da edição do Uniform Commercial Code restou consagrada no direito norte-americano não apenas a noção de que a recusa expressa em adimplir (repúdio)

395 E HUNTER TAYLOR JR, The impact of Article 2 of the U.C.C. on the Doctrine of Anticipatory Repudiation, 9 B.C.L. Rev. 917 (1968). Disponível em: <http://lawdigitalcommons.bc.edu/bclr/vol9/iss4/3〉. p. 920. Em tradução livre: "O inadimplemento antecipado do contrato ocorre quando há um definitivo e inequívoco repúdio da intenção de executar uma parte substancial do contrato na data de seu cumprimento, seja de forma expressa ou implícita, devendo a parte contrária ter conhecimento dessa intenção previamente ao prazo de cumprimento da obrigação, seja de forma direta ou indireta."

396 Aline de Miranda Valverde Terra adverte que: "O Uniform Commercial Code tem origem em um uniform $a c t$, desenvolvido por organizações privadas com o intuito de uniformizar o tratamento de determinadas questões relacionadas a venda e outras transações comerciais. O uniform act não tem, portanto, natureza jurídica de lei; trata-se apenas de recomendações, sugestões propostas aos Estados. Todavia, uma vez aprovado pelo legislativo estadual, é incorporado à legislação local. O Uniform Commercial Code foi adotado pelos cinquenta Estados americanos, tratando-se, portanto, de lei estadual." TERRA, Aline de Miranda Valverde. Inadimplemento anterior ao termo. Rio de Janeiro: Renovar. 2009. p. 146-147.

397 Em tradução livre: "Quando qualquer das partes repudia o contrato relativamente ao cumprimento de deveres ainda não exigíveis, de modo a afetar substancialmente o valor do contrato para a outra parte, a parte lesada poderá:

(a) por um tempo comercialmente razoável, aguardar o cumprimento pela parte que repudiou o contrato; ou

(b) recorrer a qualquer medida judicial cabível diante de inadimplemento (Seção 2-703 ou Seção 2711), mesmo que ela tenha notificado a outra parte que aguardaria o cumprimento e tenha urgido retratação; ou

(c) em qualquer caso, suspender sua própria execução ou proceder de acordo com os dispositivos deste Artigo sobre os direitos do vendedor de identificar os bens relacionados ao contrato não obstante o inadimplemento ou para salvar bens inacabados (Seção 2-704).” 
configuraria o inadimplemento, mas também que o comportamento do credor, a partir da assinatura do contrato e constituição da obrigação, poderia caracterizar o inadimplemento, desde que comprovado que suas ações teriam gerado a impossibilidade de cumprimento da obrigação $^{398}$.

Apesar de a teoria do inadimplemento antecipado ter sido aplicada de maneira pioneira nos países da common law, ela não se restringiu a tais nações, espraiando-se pela Europa Continental, em especial nos países de tradição romano-germânica. A primeira manifestação da teoria do inadimplemento antecipado em um sistema da civil law se deu em 1904, com a republicação da obra de Hermann Staub. Ao revisitar sua teoria das violações positivas do crédito, Staub passou a considerar que o repúdio antecipado ao contrato configurava violação positiva do crédito. A partir de então a doutrina alemã começou a discutir a possibilidade de reconhecimento do inadimplemento antecipado dos contratos $^{399}$.

Com a reforma do BGB ocorrida em 2002, foi prevista expressamente a possibilidade de reconhecimento de inadimplemento antecipado dos contratos ${ }^{400}$. Com efeito, o parágrafo 323 do BGB, que trata do tema da "revocation for nonperformance or for performance not in conformity with the contract" ${ }^{\prime 401}$, em sua subseção 4 , dispõe que "the obligee may revoke the contract before performance is due if it is obvious that the requirements for revocation will be met ${ }^{, 402}$.

O inadimplemento antecipado também foi acolhido expressamente por ordenamentos jurídicos, que passaram a dedicar dispositivos específicos da sua disciplina.

\footnotetext{
398 ANDRADE, Luis Tomás Alves de. O Inadimplemento Antecipado do Contrato no Direito Brasileiro. $R$. EMERJ, Rio de Janeiro, v. 14, n. 56, p. 145-172, out-dez. 2011. p. 152.

399 Conforme aponta Cesa Ferreira da Silva, "esta hipótese de violação positiva do contrato não estava incluída na primeira edição do texto de STAUB, sendo agregada à teoria na última parte (parte IV) da versão de 1904". SILVA, Jorge Cesa Ferreira da. A boa-fé e a violação positiva do contrato. Rio de Janeiro: Renovar. 2002, p. 222.

${ }^{400}$ VON BAR, Christian; CLIVE, Eric. Principles, definitions and mode, rules of european private law. Draft Common Frame of Reference (DCRF). Full Edition. v. I. Sellier. p. 869.

401 Em tradução livre: "revogação por descumprimento ou por descumprimento em razão da não conformidade com o contrato."

402 Em tradução livre: "o credor pode revogar o contrato antes de seu termo se for óbvio que os requisitos para revogação do contrato serão satisfeitos.”
} 
É o que se verifica no artigo 1.219 do Código Civil italiano de 1942, que passou a prever a constituição automática da mora sempre que o devedor declarar por escrito que não irá cumprir a obrigação, in verbis:

\begin{abstract}
Art. 1219. Costituzione in mora: Il debitore è costituito in mora mediante intimazione o richiesta fatta per iscritto. Non è necessaria la costituzione in mora: 1) quando il debito deriva da fatto illecito; 2) quando il debitore ha dichiarato per iscritto di non voler eseguire l'obbligazione; 3) quando è scaduto il termine, se la prestazione deve essere eseguita al domicilio del creditore. Se il termine scade dopo la morte del debitore, gli eredi non sono costituiti in mora che mediante intimazione o richiesta fatta per iscritto, e decorsi otto giorni dall'intimazione o dalla richiesta. ${ }^{403}$
\end{abstract}

A respeito dessa previsão do Código Civil italiano, Alberto Trabucchi explica que existem, no direito italiano, dois tipos de mora, a ex re e a ex persona, sendo que a principal diferença entre elas estaria na sua forma de constituição. Na mora ex re, a mora se caracteriza pelo advento do termo e independeria de qualquer ação por parte do credor. Na mora ex persona, que ocorre nas obrigações sem termo definido, a mora dependeria de uma notificação, por escrito, ao devedor. De acordo com o autor, a hipótese da recusa expressa do devedor cumprir a obrigação acarretaria mora ex re, na medida em que seria inútil notificar a quem já declarou expressamente não querer cumprir a obrigação ${ }^{404}$.

Confira-se o seguinte trecho da obra de Alberto Trabucchi nesse sentido:

La mora deve essere constatata com certezza. Il debitore viene a cadere in mora
in due modi diversi, che vanno tradizionalmente sotto il nome di mora ex re e di
mora ex persona.
Si ha mora ex re quando il debitore cade in mora senza sai necessaria alcuna
azione del creditore. Questo avviene: [...]
3) quando il debitore abbia dichiarato por iscrito di non volere eseguire la
prestazione: è inutile chiedere a chi há già palesemente dichiarato di non voler
dare. ${ }^{405}$

${ }^{403}$ Em tradução livre: “Constituição em mora. O devedor é constituído em mora por meio de notificação ou demanda feita por escrito. Não é necessária a constituição em mora: 1) quando o débito decorre de ato ilícito; 2) quando o devedor tiver declarado por escrito que não deseja executar a obrigação; 3) quando o prazo já transcorreu, se a prestação deve ser entregue no domicílio do credor. Se o prazo decorrer após a morte do devedor, os herdeiros serão constituídos em mora mediante notificação ou demanda feita por escrito, produzindo efeitos depois de oito dias a contar da notificação ou demanda."

${ }^{404}$ TRABUCCHI, Alberto. Istituzioni di diritto civile. Trentesima nona edizione aggiornata con le riforme e la giurisprudenza. Pádua: Cedam. 1999. p. 568.

${ }^{405}$ TRABUCCHI, Alberto. Istituzioni di diritto civile, Trentesima nona edizione aggiornata con le riforme e la giurisprudenza. Pádia: Cedam. 1999. p. 568. Em tradução livre: "A mora deve ser estabelecida com certeza. O devedor é constituído em mora de duas maneiras diferentes, que são tradicionalmente 
Com efeito, a doutrina entende que a noção de que a recusa do devedor constitui automaticamente a mora se mostrou um enorme avanço para o instituto do inadimplemento antecipado no direito italiano, pois acabou por consagrar a ideia de que a declaração expressa de não querer adimplir funcionaria como uma forma de antecipação do termo contratual ${ }^{406}$.

O Código Civil Espanhol, embora não contenha disposição genérica sobre o inadimplemento antecipado, contém regra específica a respeito do inadimplemento antecipado relativa à compra e venda de bens imóveis, estabelecendo que, se o vendedor que tiver entregado a coisa e o pagamento tiver sido pactuado a termo, o vendedor poderá considerar o contrato resolvido se tiver fundado motivo para temer a perda da coisa e do preço $^{407}$ :

Art. 1.503. Si el vendedor tuviere fundado motivo para temer la pérdida de la cosa inmueble vendida y el precio, podrá promover inmediatamente la resolución de la venta. Si no existiere este motivo, se observará lo dispuesto en el artículo $1.124 .^{408}$

Apesar de não existir uma previsão expressa sobre o inadimplemento antecipado no Código Civil português, a doutrina portuguesa discute se a recusa antecipada

denominadas mora ex re e mora ex personae. Há mora ex re quando o devedor é constituído em mora sem a necessidade de qualquer ação do credor. Isso ocorre: [...]

3) quando o devedor tiver declarado por escrito que não quer executar a prestação: é inútil pedir àqueles que declararam expressamente que não querem prestar."

406 ANDRADE, Luis Tomás Alves de. O Inadimplemento Antecipado do Contrato no Direito Brasileiro. $R$. EMERJ, Rio de Janeiro, v. 14, n. 56, p. 145-172, out-dez. 2011, p. 151.

${ }^{407}$ Com relação à previsão de inadimplemento antecipado no direito espanhol, Luis Diez Picazo e Antonio Gullon afirmam que "Si el vendedor ha entregado la cosa y la prestación del comprador se ha aplazado, aquél puede promover inmediatamente la resolución del contrato caso de que tuviere motivo fundado para temer la pérdida de la cosa y del precio. Es una excepción al artículo 1.224, pues aún no existe incumplimiento del contrato y se acciona para resolverlo en base a un temor fundado de que el comprador no cumplirá y que la cosa a restituir, en consecuencia, no se devolverá". DIEZ-PICAZO, Luis e GULLON, Antonio. Sistema de Derecho Civil. v. II. Madrid: Editorial Tecnos. 1978. p. 239. Em tradução livre: "se o devedor tiver entregado a coisa e a prestação do comprador tiver sido pactuada a prazo, aquele pode promover imediatamente a resolução do contrato se tiver motivo fundado para temer a perda da coisa e do preço. É uma exceção ao artigo 1.224, pois ainda que não exista inadimplemento do contrato, se requer a sua resolução com base em um temor fundado de que o comprador não cumprirá e que a coisa a restituir, por consequência, não será devolvida."

${ }^{408}$ Em tradução livre: "Se o vendedor tiver fundado motive para temer a perda da coisa imóvel vendida e do preço, poderá promover imediatamente a resolução da venda. Se não existir esse motivo, observar o disposto no artigo 1.124." 
em adimplir constituí um inadimplemento, que autoriza o credor a resolver o contrato, ou simplesmente uma mora debitoris, que obriga o credor a notificar o devedor fixando prazo para o credor adimplir para evitar a resolução do contrato ${ }^{409}$.

No âmbito do direito internacional, a Convention on Contracts for the International Sales of Goods expressamente menciona a figura do inadimplemento antecipado. A respeito da quebra antecipada dispõe o artigo 72 da referida convenção:

(1) If prior to the date for performance of the contract it is clear that one of the parties will commit a fundamental breach of contract, the other party may declare the contract avoided.

(2) If the time allows, the party intending to declare the contract avoided must give reasonable notice to the other party in order to permit him to provide adequate assurance of his performance.

(3) The requirements of the preceding paragraph do not apply if the other party has declared that he will not perform his obligations. ${ }^{410}$

Como se observa, o artigo 72 estabelece que, se antes da data do cumprimento da obrigação, for manifesto que uma parte cometerá uma violação fundamental do contrato de compra e venda de bens móveis, a outra parte poderá buscar a resolução deste contrato por inadimplemento antecipado. Pelo dispositivo da Convention on Contracts for the International Sales of Goods, confere-se à parte o direito de considerar o contrato imediatamente extinto se antes do advento do termo contratual ficar claro ("it is clear") que a contraparte cometerá inadimplemento fundamental.

Em comentários sobre o referido dispositivo, Schlechtriem \& Schwenzer afirmam que são requisitos para o direito de rescisão do contrato por inadimplemento antecipado "(1) estar claro antes da data de adimplemento que (2) o devedor irá cometer uma violação essencial do contrato. (3) Então, se o prazo permitir, (4) o credor deve

\footnotetext{
${ }^{409}$ VON BAR, Christian, CLIVE, Eric. Principles, definitions and mode, rules of european private law. Draft Common Frame of Reference (DCRF). Full Edition. v. I. Sellier. p. 870.

${ }^{410}$ Em tradução livre: "(1) Caso antes do prazo previsto para o cumprimento da obrigação contratual, esteja claro que uma das partes cometerá um inadimplemento contratual fundamental, a outra parte poderá declarar o contrato sem efeito.

(2) Se houver tempo, a parte com intenção de declarar o contrato sem efeito deverá dar aviso prévio razoável à outra parte a fim de lhe permitir que providencie garantia adequada de cumprimento.

(3) Os requisitos do parágrafo anterior não se aplicam caso a outra parte tenha declarado que não cumprirá a sua obrigação contratual."
} 
fornecer uma notificação razoável ao devedor, informando que pretende rescindir o contrato. (5) Se o devedor não prestar a garantia adequada, pode o credor (6) rescindir o contrato",411.

Jelena Vilus pondera que o fato de a convenção autorizar uma parte a buscar a resolução do contrato caso de inadimplemento antecipado

[...] is fully justified since it would not be right that one party remains bound by the contract when the other has, for instance, deliberately declared that he will not carry out one of his fundamental obligations or when he conducts himself in such a way that it is clear that he will commit a fundamental breach of contract. $^{412}$

A autora adverte, todavia, que a grande dificuldade da utilização da figura do anticipatory breach prevista na Convention on Contracts for the International Sales of Goods é identificar corretamente quando ocorrerá uma violação fundamental do contrato e considerar os riscos e impactos da adoção equivocada das medidas previstas no artigo 72 para o devedor, o que será analisado nos tópicos adiante ${ }^{413}$.

${ }^{411}$ SCHLECHTRIEM, Peter; SCHWENZER, Ingeborg. Comentários à Convenção das Nações Unidas sobre Contratos de Compra e Venda Internacional de Mercadorias. Coordenação de tradução de Eduardo Grebler, Vera Fradera, César Guimarães Pereira. São Paulo: Editora Revista dos Tribunais, 2014. p. 1.079.

${ }^{412}$ VILUS, JELENA. Provisions common to the obligations of the seller and the buyer. In: International Sale of Goods. Dubrovnik Lectures. Oceana Publications. 1986. p. 244. Em tradução livre: “é plenamente justificada, uma vez que não seria justo que uma parte permaneça vinculado ao contrato, quando o outro, por exemplo, deliberadamente declarou que não irá cumprir com uma de suas obrigações fundamentais ou quando essa parte se comporta de tal maneira que resta claro que vai cometer uma violação fundamental do contrato."

${ }^{413}$ Nesse sentido: "In regard to anticipatory breach of contract, the basic question is whether the party that doubts the performance of the other party has the right to suspend or avoid the contract prior to the date for performance. In other words, if the situation and the circumstances change during the performance of the contract and one of the parties is of the opinion that the other will not be able to fulfill his obligations, the question arises whether this party should wait until the other party becomes insolvent, for instance, or whether in such a case he himself should decide to suspend performance or his obligations and demand additional guarantees. On the other hand, what would happen if his evaluation of the other party's ability to perform his groundless and the other party subsequently suffer financial loss as a result of the anticipatory breach? These dilemmas will have to be solved by arbitrators or judges deciding disputes involving international contracts of sale and were the same problems which were discussed at the Vienna Conference during preparation and adoption of the relevant provisions".(VILUS, JELENA. Provisions common to the obligations of the seller and the buyer. In: International Sale of Goods. Dubrovnik Lectures. Oceana Publications. 1986. p. 240) Em tradução livre: "Em relação ao inadimplemento antecipado do contrato, a questão básica é se a parte que duvida do desempenho da parte contrária tem o direito de suspender ou tornar o contrato sem efeito antes da data de sua execução. Em outras palavras, se a situação e as circunstâncias mudam durante a execução do contrato e uma das partes é da opinião de que o outro não será capaz de cumprir com as suas obrigações, surge a questão de se essa parte deverá aguardar até que a outra parte se torne insolvente, por exemplo, ou se, nesse caso, ele mesmo deverá decidir suspender a execução do contrato 
Outrossim, o artigo 7.3.3 dos princípios UNIDROIT relativos aos Contratos Comerciais Internacionais também determina que, quando antes da data estipulada para o desempenho da prestação, uma das partes deixar claro que não desempenhará a obrigação, a outra parte poderá pôr fim ao contrato, ou seja, poderá resolvê-lo. Com efeito, o referido artigo dispõe que "uma parte poderá extinguir o contrato se, anteriormente ao termo de sua execução, resulta claro que haverá inadimplemento essencial pela outra parte"414.

Nos seus comentários sobre o artigo 7.3.3 dos princípios UNIDROIT relativos aos Contratos Comerciais Internacionais, João Baptista Villela assevera que o mencionado dispositivo "estabelece o princípio de que o inadimplemento que é esperado equipara-se ao inadimplemento que ocorreu no momento em que a prestação tornou-se devida" ${ }^{415} \mathrm{O}$ referido autor complementa que "é uma exigência que reste claro que haverá um inadimplemento; uma suspeita, ainda que bem fundamentada, não é suficiente" e que "é preciso que o inadimplemento seja substancial". 416

Na obra Principles, definitions and model rules of european private law, em que consta um esboço de Código Civil a ser adotado nos países que compõem a União Europeia - Draft Common Frame of Reference (DCFR) - também está previsto no artigo 504 que "a creditor may terminate before performance of a contractual obligation is due if the debtor has declared that there will be a non-performance of the obligation, or it is otherwise clear that there will be such a non-performance, and if the non-performance would have been fundamental"417.

ou cumprir com as suas obrigações e exigir garantias adicionais. Por outro lado, o que aconteceria se a sua avaliação da capacidade da outra parte fosse infundada e que a outra parte, posteriormente, sofresse com o resultado do inadimplemento antecipado? Estes dilemas terão que ser resolvidos por árbitros ou juízes que decidem os litígios que envolvam contratos internacionais de venda e são os mesmos problemas que foram discutidos na Conferência de Viena durante a preparação e adoção das disposições relevantes."

414 VILLELA, João Baptista et al. Princípios UNIDROIT relativos aos Contratos Comerciais Internacionais/2004 [versão em língua portuguesa]. São Paulo: Quartier Latin. 2009. p. 238.

415 VILLELA, João Baptista et al. Princípios UNIDROIT relativos aos Contratos Comerciais Internacionais/2004 [versão em língua portuguesa]. São Paulo: Quartier Latin. 2009. p. 238-239.

416 VILLELA, João Baptista et al. Princípios UNIDROIT Relativos aos Contratos Comerciais Internacionais/2004 [versão em língua portuguesa]. São Paulo: Quartier Latin, 2009. p. 238-239.

${ }^{417}$ VON BAR, Christian, CLIVE, Eric. Principles, definitions and mode, rules of european private law. Draft Common Frame of Reference (DCRF). Full Edition. v. I. Sellier. p. 867. Em tradução livre: "um credor poderá encerrar a obrigação contratual antes mesmo de ser devida se o devedor tiver declarado que não a 
Em comentários ao referido artigo 504 do DCFR, Christian von Bar e Eric Clive afirmam que o dispositivo autoriza o credor a resolver o contrato se o devedor tiver repudiado o contrato afirmando que não iria realizar a prestação ou se ficar evidente (“it is otherwise clear") que ocorrerá um inadimplemento contratual fundamental. Os autores complementam que "the main effect of the Article is that for the purpose of the remedy of termination a clearly anticipated fundamental non-performance is equated with an actual fundamental non-performance after performance has become due"418.

Christian von Bar e Eric Clive comentam que o direito de o credor resolver o contrato se baseia na noção de que não seria razoável exigir que o credor continue vinculado às suas obrigações se restar claro que o devedor não adimplirá no termo pactuado $^{419}$. Os autores advertem, todavia, que o direito de resolver o contrato em caso de inadimplemento antecipado só pode ser exercido quando a obrigação principal for de um tipo que o seu descumprimento autorizaria o credor a resolver o contrato desde logo ou quando houver um atraso substancial no adimplemento.

Confira-se o posicionamento dos autores sobre a questão:

Termination under this Article is permitted only where the main obligation is of such a kind that its non-performance would entitle the creditor to terminate. This applies also to a threatened delay in performance. If a debtor indicates that there will be performance but that it will be late this, in the absence of an agreed right to terminate, does not satisfy the requirements of the Article except where the threatened delay is also so serious as to constitute a fundamental nonperformance. ${ }^{420}$

cumprirá ou se estiver claro que haverá um descumprimento, sendo este descumprimento fundamental para o cumprimento da obrigação.".

${ }^{418}$ VON BAR, Christian, CLIVE, Eric. Principles, Definitions and Mode, Rules of European Private Law. Draft Common Frame of Reference (DCRF). Full Edition. v. I. Sellier. p. 867. Em tradução livre: "o principal efeito deste Artigo é que para os fins do recurso da rescisão, o inadimplemento antecipado é equiparado a um inadimplemento fundamental depois que o cumprimento se tornou exigível."

${ }^{419}$ VON BAR, Christian, CLIVE, Eric. Principles, definitions and mode, rules of european private law. Draft Common Frame of Reference (DCRF). Full Edition. v. I. Sellier. p. 868.

${ }^{420}$ VON BAR, Christian, CLIVE, Eric. Principles, definitions and mode, rules of european private law. Draft Common Frame of Reference (DCRF). Full Edition. v. I. Sellier. p. 886. Em tradução livre: “A rescisão à luz desse Artigo é permitida somente quando a obrigação principal é de tal natureza que o seu inadimplemento daria ao credor o direito de rescindir o contrato. Isso se aplica também à ameaça de atraso no cumprimento da obrigação. Se um devedor indicar que haverá adimplemento das obrigações, mas que ocorrerá com atraso, 
Observa-se, assim, que a tendência no direito estrangeiro e internacional é no sentido de que o inadimplemento antecipado do contrato ocorrerá quando, antes do advento do termo ajustado entre as partes, se verificar com alto grau de probabilidade que a obrigação não será desempenhada em virtude do comportamento adotado pelo devedor, ainda que tacitamente. Em outras palavras, o escopo do instituto do inadimplemento antecipado do contrato é, primordialmente, poupar o credor dos prejuízos resultantes do futuro inadimplemento contratual, em especial nos casos em que as condições fáticas demonstrem o desinteresse do devedor no cumprimento da obrigação.

\subsection{Inadimplemento antecipado: o conceito, a estrutura lógico-sistemática e os requisitos para a sua aplicação no direito brasileiro}

A precisa configuração do inadimplemento antecipado é fundamental para que se produzam os efeitos dele decorrentes. Trata-se de importante instrumento de tutela do credor, "e não de válvula de escape para que, arrependido do contrato celebrado, aproveitese de conduta duvidosa do devedor para, considerando-o inadimplente, livrar-se da indesejada relação contratual” ${ }^{421}$. A exata configuração do inadimplemento antecipado é imprescindível, sob pena de se adotar contra o devedor medida mais rigorosa do que aquela que seja a legítima consequência do seu comportamento. Para tanto, serão analisados a seguir os requisitos que caracterizam o inadimplemento antecipado.

\subsubsection{Elemento objetivo}

Como exposto no primeiro capítulo, há inadimplemento absoluto quando a prestação devida, após a constituição da obrigação, se tornar impossível ou inútil para o credor. Por outro lado, configura-se a mora quando a prestação não for cumprida no tempo, forma ou lugar pactuados, mas, ainda assim, apresenta-se útil ao credor. Para fins do presente estudo, impõe-se verificar em que circunstâncias a atuação ou a omissão do

isso, na ausência de um acordo de um direito de rescindir o contrato, não preenche aos requisitos deste Artigo, salvo se a ameaça de atraso é tão grave a ponto de constituir um inadimplemento fundamental."

${ }^{421}$ TERRA, Aline de Miranda Valverde. Inadimplemento anterior ao termo. Rio de Janeiro: Renovar. 2009. p. $159-160$. 
devedor impossibilita ou inutiliza a prestação para o credor e caracteriza inadimplemento antecipado.

\subsubsection{Inadimplemento antecipado por recusa}

O primeiro suporte fático objetivo a ser examinado é a manifestação do devedor de não querer adimplir. Com efeito, o comportamento do devedor - que revela expressa ou tacitamente a sua intenção de não adimplir - é o elemento constante em todas as definições de inadimplemento antecipado, desde aquelas que remontam à origem do anticipated breach of contract da common law, e até mesmo naquelas elaboradas recentemente pela doutrina brasileira.

De maneira geral, a doutrina entende que o repúdio ou recusa do devedor ao cumprimento da obrigação pode se dar de duas formas: pela declaração expressa no sentido de não adimplir (manifestação expressa) ou pela conduta concludente do devedor que demonstre que ele não irá adimplir (manifestação tácita). ${ }^{422}$ Confiram-se, a seguir, as lições de Fortunato Azulay a respeito do tema:

[...] se uma das partes manifesta, unilateralmente, por antecipação ao termo de execução, a sua intenção de não cumprir, ou revela por fatos, atos ou palavras inequívocas e insofismáveis que se tornou impossível (em sentido técnicojurídico), ou duvidoso o cumprimento da prestação, sofrera, também, naturalmente, as sanções de sua pré-inadimplência. ${ }^{423}$

Na manifestação expressa, a recusa compreende "a manifestação inequívoca da intenção do devedor em não cumprir a prestação futura". ${ }^{424} \mathrm{O}$ devedor declara explicitamente que não cumprirá a prestação, por não querer ou não poder fazê-lo, de modo a não satisfazer o interesse do credor.

\footnotetext{
${ }^{422}$ Nesse sentido, Jorge Cesa Ferreira da Silva afirma que “esta 'recusa' pode dar-se de duas formas: pela declaração antecipada ou pela conduta concludente do devedor. Em qualquer uma das hipóteses, a recusa deverá ser séria, demonstrando sua definitividade". SILVA, Jorge Cesa Ferreira da. A boa-fé e a violação positiva do contrato. Rio de Janeiro: Renovar. 2002. p. 229.

${ }^{423}$ AZULAY, Fortunato. Do inadimplemento antecipado do contrato. Rio de Janeiro: Editora Brasília/Rio. 1977. p. 74.

${ }^{424}$ MARTINS, Raphael Manhães. Inadimplemento antecipado: perspectiva para a sua aplicação no Direito brasileiro. Revista Forense, Rio de Janeiro, v. 391, ano 103, mai./jun. 2007, p. 210.
} 
É o caso, por exemplo, do jogador de futebol que, após celebrar contrato de exclusividade com determinado time de futebol brasileiro, comprometendo-se a se apresentar ao clube no começo do ano seguinte, declara para a imprensa esportiva que romperá o contrato assinado e que está em negociações com outro time europeu.

No entanto, cumpre mencionar que a declaração de não cumprir será implícita na maior parte dos $\operatorname{casos}^{425}$, valendo-se o devedor de justificativas ilegítimas para explicar o futuro inadimplemento do contrato ou a sua nulidade. Para ilustrar, pode ser citado o caso da incorporadora imobiliária que se compromete a entregar um apartamento no prazo de 2 (dois) anos, mas envia comunicado aos proprietários informando que a conclusão da obra atrasará pelo menos 1 (um) ano em virtude da escassez de mão de obra e materiais de construção no mercado. Esse tipo de declaração também caracteriza o suporte fático do inadimplemento.

Destaque-se que não é qualquer declaração que poderá caracterizar inadimplemento antecipado. Impõe-se que tal declaração seja séria, dotada de certeza e definitividade e livre de quaisquer vícios de consentimento ${ }^{426}$. Nesse sentido, afirma-se que "tem-se admitido que a manifestação antecipada do devedor em não adimplir pode caracterizar de forma segura o incumprimento antecipado, desde que ela seja apresentada

\footnotetext{
${ }^{425}$ Schlechtriem \& Schwenzer afirmam que "na prática, a recusa de uma obrigação será frequentemente disfarçada. O devedor irá alegar injustificadamente que está titulado a se retirar do contrato ou que o contrato não é eficaz. Exemplo de uma recusa antecipada seria o pedido de aumento injustificado do preço, a alegação de direito a prazo adicional, ou outro tipo de modificação contratual. Todas essas alegações são recusas em cumprir o contrato, desde que elas deixem claro que, de outra forma, o devedor não irá cumprir com os seus deveres". SCHLECHTRIEM, Peter; SCHWENZER, Ingeborg. Comentários à Convenção das Nações Unidas sobre Contratos de Compra e Venda Internacional de Mercadorias. Coordenação de tradução de Eduardo Grebler, Vera Fradera, César Guimarães Pereira. São Paulo: Editora Revista dos Tribunais. 2014. p. 1.087 .

${ }^{426}$ Cristiano de Sousa Zanetti ressalta "a importância de se aferir a seriedade da declaração daquele que afirma não pretender cumprir o pactuado. Pode ocorrer, por exemplo, que sua manifestação não passe de uma bravata, motivada pelo comportamento do credor. Nessa situação, o registro do fato não será suficiente para dar por extinta a relação contratual. Em adição, convém verificar a higidez da declaração, pois sua emanação pode provir de algum vício da vontade, como o erro". ZANETTI, Cristiano de Souza. Inadimplemento Antecipado da Obrigação Contratual. In: CELLI JUNIOR, Umberto; BASSO, Maristela; AMARAL JÚNIOR, Alberto do (Coord.). Arbitragem e comércio internacional: estudos em homenagem a Luiz Olavo Baptista. São Paulo: Quartier Latin. 2013. p. 328.
} 
em condições tais que exprimam uma absoluta e inequívoca intenção de repúdio ao contrato, de forma séria e definitiva" ${ }^{\$ 27}$.

A doutrina não apresenta qualquer tipo de divergência com relação à necessidade da certeza e seriedade da declaração, haja vista que não há como permitir que "manifestações jocosas, incertas ou mesmo desprovidas de definitividade acarretem a antecipação do termo contratual" ${ }^{428}$. Todavia, Ruy Rosado de Aguiar Júnior exige, além da declaração expressa do devedor, um "comportamento efetivo [do devedor] contra a prestação, de tal sorte se possa deduzir, conclusivamente, dos dados objetivos existentes, que não haverá o cumprimento" 429 .

Para o autor, portanto, é necessário que a declaração expressa de não poder ou não querer adimplir também esteja acompanhada de declaração tácita de não querer ou não poder adimplir. Entretanto, a nosso ver, a declaração expressa de não querer adimplir já é suficiente para fins de caracterização do inadimplemento antecipado, pois demonstra a falta de comprometimento do devedor com o programa obrigacional e um grave abalo à legítima expectativa do credor de que a prestação devida será cumprida nos termos pactuados.

Ruy Rosado de Aguiar Júnior sustenta, ainda, que a manifestação do devedor obtida por meio de interpelação do credor antes do vencimento não tem o condão de conduzir ao inadimplemento antecipado. $\mathrm{O}$ autor aduz que o credor não pode intimidar o devedor por meio de interpelações quando ainda pende termo para que o devedor cumpra seus deveres. Entretanto, o próprio autor ressalva que, se esta interpelação afigurar-se como simples meio de verificação dos procedimentos obrigacionais, como forma de demonstrar situação de evidente inadimplemento, poderá admitir-se a interpelação do

\footnotetext{
427 AGUIAR JR., Ruy Rosado. Extinção dos contratos por incumprimento do devedor (resolução). Rio de Janeiro: Aide. 1991. p. 129.

${ }_{428}$ ANDRADE, Luis Tomás Alves de. O Inadimplemento Antecipado do Contrato no Direito Brasileiro. $R$. EMERJ, Rio de Janeiro, v. 14, n. 56, p. 145-172, out-dez. 2011, p. 156.

${ }^{429}$ AGUIAR JR., Ruy Rosado. Extinção dos contratos por incumprimento do devedor (resolução). Rio de Janeiro: Aide. 1991. p. 126.
} 
credor como meio idôneo a se obter a manifestação do devedor para fins de caracterização de inadimplemento antecipado ${ }^{430}$.

Estamos de acordo com a ressalva feita por Ruy Rosado de Aguiar Júnior. Entendemos que o dever de informação, dever anexo decorrente do princípio da boa-fé objetiva, confere ao credor o direito de - pautado por uma razoabilidade e de maneira fundamentada - solicitar informações periódicas relacionadas à execução do contrato, especialmente naqueles contratos de execução continuada. Assim, desde que a postura do credor esteja pautada pelo padrão de comportamento esperado pela boa-fé objetiva, o credor poderá interpelar o devedor para verificar o status do cumprimento da sua obrigação e, a depender da resposta do devedor - se houver uma manifestação com razoável grau de certeza e definitividade -, restará configurado o inadimplemento antecipado.

Fortunato Azulay afirma que a declaração de não querer adimplir constitui declaração unilateral de vontade, sujeita às mesmas regras legais ou interpretativas que presidem a formação do contrato, no que couber ${ }^{431}$. A esse respeito, Aline Terra classifica a declaração de não querer adimplir como uma declaração receptícia de vontade ${ }^{432}$, razão pela qual deveria ser dirigida ao credor e por ele recebida para ser eficaz ${ }^{433}$. A autora

\footnotetext{
430 Confira-se a posição de Ruy Rosado de Aguiar Júnior: “deve ser vista com reserva, porquanto a interpelação pode simplesmente demonstrar a preocupação do credor em definir uma situação já evidenciada pelos fatos antecedentes. Portanto, se a iniciativa do credor tem fundado amparo nas circunstâncias do contrato, especialmente diante do comportamento do devedor, não há como, desde logo, recriminar o comportamento do credor que queira obter uma definição sobre a real intenção do devedor relativamente ao contrato". AGUIAR JR., Ruy Rosado. Extinção dos contratos por incumprimento do devedor (resolução). Rio de Janeiro: Aide. 1991. p. 129.

${ }^{431}$ AZULAY, Fortunato. Do inadimplemento antecipado do contrato. Rio de Janeiro: Editora Brasília/Rio. 1977. p. 69.

${ }^{432}$ TERRA, Aline de Miranda Valverde. Inadimplemento anterior ao termo. Rio de Janeiro: Renovar. 2009. p. 163.

${ }^{433}$ A respeito das declarações receptícias de vontade, veja-se: “A declaração de vontade pode emitir-se às vezes dirigida a uma pessoa determinada, seja com o propósito de levar-lhe ao conhecimento a intenção do agente, seja com a finalidade de se ajustar a outra declaração de vontade oposta, necessária à perfeição do negócio jurídico. Chama-lhe a doutrina declaração receptícia de vontade. Estão nesses casos a proposta de contrato, a revogação do mandato, etc. Mas, outras vezes, a emissão se faz sem aquele caráter, e mesmo assim o negócio jurídico se completa, dizendo-se que há uma declaração não-receptícia de vontade, de que se podem invocar como exemplos o testamento, a promessa ao público, etc. A distinção entre uma e outra se faz, esclarecendo-se que, tanto a receptícia quanto a não-receptícia, influi a declaração de vontade na esfera jurídica de outrem; porém, na primeira hipótese o ato exige, para completar-se, uma parte e outra parte, com sentido direcional, enquanto que, na segunda, o negócio jurídico se completa só com a vontade do declarante, seja este uma pessoa natural, uma pessoa jurídica ou uma coletividade.” PEREIRA, Caio Mário da Silva. Instituições de direito civil. Rio de Janeiro: Forense. 2005. p. 484.
} 
considera, ainda, que a declaração de não querer adimplir prescinde da concordância do credor e que é exigido apenas o seu conhecimento, concluindo que "basta a ciência do credor para que a declaração produza seus efeitos, não se exigindo, portanto, qualquer atuação de sua parte. Consequentemente, ciente o credor, eficaz a declaração ${ }^{434}$.

Em sentido oposto, Anelise Becker entende que somente haverá inadimplemento quando a contraparte também o considerar e aceitar. A autora afirma que “a recusa, por si só, não é considerada ipso facto um inadimplemento, pois entende-se que

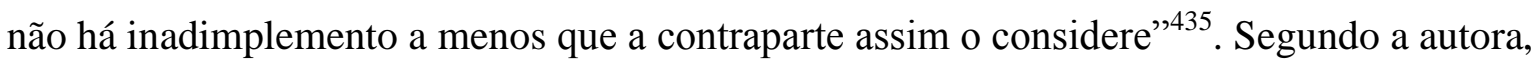
é plenamente cabível que, caso o credor assim deseje, possa dar como ineficaz a notícia da intenção de não adimplir, tornando sem efeito a recusa em adimplir e aguardando-se o advento do termo contratual ${ }^{436}$. Contudo, a própria autora adverte que não é permitido ao credor manter unicamente o contrato com o propósito de, em oposição à recusa, exigir do devedor o pagamento total da avença. Tratar-se-ia, nesse caso, de exercício abusivo de direito $^{437}$.

\footnotetext{
434 TERRA, Aline de Miranda Valverde. Inadimplemento anterior ao termo. Rio de Janeiro: Renovar. 2009. p. 164-165. No mesmo sentido, Fortunato Azulay assevera que não é necessário que o credor aceite a declaração de não adimplir do devedor, afirmando que se entende "atualmente, que, nem notificação da aceitação do repúdio é exigida, nem o retardo em propor a ação judicial respectiva por inadimplência antecipada, pode ser causa de improcedência do direito do credor". AZULAY, Fortunato. Do inadimplemento antecipado do contrato. Rio de Janeiro: Editora Brasília/Rio. 1977. p. 129-130.

${ }^{435}$ BECKER, Anelise. Inadimplemento antecipado do contrato. Revista de Direito do Consumidor, São Paulo: Revista dos Tribunais, n. 12, 1994, p. 72-73.

${ }^{436}$ A esse respeito, G. H. Treitel afirma que, no sistema da common law, o devedor tem a opção de escolher manter o contrato ou "aceitar" o inadimplemento do contrato, requerendo a sua resolução. Confira-se: "one of the parties to contract may, before the time fixed for performance, say that he will not perform, or incapacitate himself from performing. Such conduct is sometimes called 'anticipatory breach'. The other party then has a choice. He can try to keep the contract alive by continuing to press for performance, in which case the anticipatory breach will have the same effects as an actual breach. Alternatively, he can 'accept' the breach, in which case his rights to damages and rescission are governed by special rules to be discusses below.” TREITEL, G. H. The law of contract. Sixth Edition. Stevens \& Sons: London, 1983. p. 642. Em tradução livre: "uma das partes do contrato poderá, antes do prazo fixado para adimplemento, dizer que não irá cumprir com as obrigações ou incapacitar-se da execução do contrato. Tal conduta é às vezes chamada de 'inadimplemento antecipado'. A outra parte, então, tem uma escolha. Ela pode tentar manter o contrato vivo ao continuar a pressionar pelo cumprimento, caso em que o inadimplemento antecipado terá os mesmos efeitos de um inadimplemento concreto. Como alternativa, ela pode 'aceitar' o inadimplemento, caso em que os seus direitos para rescisão e pleitear danos serão regidos por normas especiais que serão discutidas abaixo."

${ }^{437}$ BECKER, Anelise. Inadimplemento antecipado do contrato. Revista de Direito do Consumidor, São Paulo: Revista dos Tribunais, n. 12, 1994, p. 73.
} 
Sem retirar a importância do posicionamento da segunda autora, entende-se que a primeira visão se mostra mais condizente com a atual concepção de obrigação, na qual se avulta a importância da boa-fé objetiva. Atenta contra a boa-fé o comportamento do credor que, mesmo ciente de que o devedor não adimplirá no termo previsto contratualmente, não adota nenhuma postura para a imediata defesa dos seus direitos e se queda inerte esperando o advento do termo contratual. A nosso ver, a não aceitação, pelo credor, da declaração de não querer ou não poder adimplir vai de encontro ao duty to mitigate the loss (teoria da mitigação das perdas), que será brevemente estudado adiante e imputa às partes a responsabilidade por todo o dano que conscientemente deixou de evitar.

Desta feita, consideramos que a declaração de não querer adimplir não requer a concordância do credor, exigindo-se apenas o seu conhecimento (sendo, portanto, uma típica declaração receptícia de vontade), e que pouco importa a forma que o devedor utilizou para se manifestar, sendo apenas necessário que a declaração tenha atingido a ciência do credor.

De acordo com Lacerda de Almeida, a declaração unilateral vigora e produz todos os seus efeitos até ser retratada ${ }^{438}$. Nesse sentido, importa investigar a partir de que momento a declaração de não querer adimplir se torna obrigatória para o devedor. Sobre esse tema específico, Fortunato Azulay afirma que a jurisprudência norte-americana entende que a retratação é possível, desde que seja oportunamente feita pela parte repudiante ou provocada pelo próprio devedor ${ }^{439}$.

Ruy Rosado de Aguiar Júnior destaca dois aspectos que considera relevantes sobre esta questão. "O primeiro deles é de que ninguém é dado venire contra factum proprium", o que significa dizer que quem provoca, na outra parte, fundada expectativa de que a prestação não será adimplida, não pode depois voltar atrás e se dispor a adimplir, especialmente se o credor já tiver proposto medida judicial. Em contrapartida, o autor ressalva que não se pode esquecer os princípios da vinculação e da obrigatoriedade, sendo

\footnotetext{
${ }^{438}$ LACERDA DE ALMEIDA, Francisco de Paula. Obrigações. 2. ed. Rio de Janeiro: Revista dos Tribunais. 1916. p. 202.

${ }^{439}$ AZULAY, Fortunato. Do inadimplemento antecipado do contrato. Rio de Janeiro: Editora Brasília/Rio. 1977. p. 129-130.
} 
sempre preferível o cumprimento dos contratos. Sob esse argumento, ele sustenta que se deve permitir ao devedor se retratar em juízo, assim que for citado, adimplindo. Ao final, ele conclui que "ao juiz cabe examinar se essa variação de conduta não provocou a eliminação do interesse do credor, que pode ter buscado outras soluções, em face da declaração do devedor" ${ }^{\text {440 }}$.

Estamos de acordo com o posicionamento do Ruy Rosado de Aguiar Júnior no sentido de que a retratação é possível a depender do caso concreto. Como regra geral, entendemos que a declaração do devedor de não querer ou não poder adimplir já é suficiente para caracterizar o inadimplemento antecipado, bastando a mera ciência do credor para que produza efeitos. No entanto, excepcionalmente, quando o devedor se retratar - ainda que extrajudicialmente -, comprovando que pretende e tem condições de adimplir no tempo, modo e lugar pactuados, e a prestação ainda for útil para o credor, a retratação do devedor poderá ser admitida.

Feitas essas observações sobre a manifestação expressa de não querer adimplir, passaremos ao exame da manifestação tácita de não adimplir. A manifestação tácita se verifica nas situações nas quais o devedor se comporta no sentido oposto ao do adimplemento, ou seja, nas situações em que é possível inferir da conduta do devedor que ele não pretende cumprir a sua obrigação. É o que se denomina manifestação tácita de não querer adimplir.

Conforme assinala Ruy Rosado Aguiar Júnior, “o incumprimento antecipado pode resultar de conduta contrária do devedor, por ação (venda do estoque, sem perspectiva de reposição), ou omissão (deixar de tomar as medidas prévias indispensáveis para a prestação)", que revela que o devedor não quer ou não conseguirá adimplir a obrigação $^{441}$.

\footnotetext{
${ }^{440}$ AGUIAR JR., Ruy Rosado. Extinção dos contratos por incumprimento do devedor (resolução). Rio de Janeiro: Aide. 1991. p. 129-130.

${ }^{441}$ AGUIAR JR., Ruy Rosado. Extinção dos contratos por incumprimento do devedor (resolução). Rio de Janeiro: Aide. 1991. p. 127.
} 
Pode ser mencionado o caso em que, em contrato de compra e venda de unidades imobiliárias em construção, a inércia do empreiteiro acarreta um considerável atraso na entrega do empreendimento, que tem remotas condições de ser entregue na data pactuada pelas partes.

Também pode ser citada a situação em que duas partes celebram um contrato de arrendamento de terra, em que restou pactuado que uma parte plantaria soja no terreno e que dividiria um percentual dos lucros da venda da soja com o arrendador, proprietário do terreno. Na hipótese de o arrendatário suspender a produção de soja depois de um ano e meio do contrato, restará caracterizado o inadimplemento antecipado.

Mencione-se ainda o caso de um Turnkey Construction Contract, cujo objeto consiste na construção de uma usina hidrelétrica, em que a empreiteira atrasa demasiadamente as primeiras fases do projeto e torne inviável a entrega da obra no prazo pactuado.

As situações descritas acima demonstram que também serve de suporte ao inadimplemento antecipado o comportamento omissivo ou comissivo do devedor que inviabiliza o adimplemento do contrato no prazo pactuado entre as partes (ou seja, que provoca um retardamento na entrega prestação devida). Nestes casos, a prestação ainda pode ser cumprida, mas o atraso no cumprimento dos atos relativos ao adimplemento caracteriza o inadimplemento antecipado.

O pressuposto para a caracterização dessa hipótese de inadimplemento antecipado é aquela situação em que se consegue prever com segurança que a prestação não será entregue no termo contratual, ou seja, que haverá um retardamento no cumprimento da obrigação.

Observe-se que não é necessária a certeza absoluta de que o devedor não cumprirá a prestação, ou que, de fato, raramente acorrerá. É suficiente que se evidencie, 
com probabilidade próxima à certeza $a^{442}$, a intenção de não adimplir, exteriorizada por meio de conduta do devedor incompatível com o padrão de comportamento de quem pretende cumprir a prestação devida ${ }^{443}$. É esse o pressuposto fático do inadimplemento antecipado.

Vale acrescentar que, nas manifestações expressas ou tácitas de não querer adimplir, deve-se atribuir às manifestações sentido amplo, de maneira que elas signifiquem não apenas a intenção de não cumprir a prestação devida, mas também a de não cumprir nos termos pactuados. Nesse sentido, Aline Terra afirma que "a declaração de uma das partes de que apenas cumprirá sua prestação se a outra aceitar condições contratuais inadmissíveis, equivale a recusa a adimplir o contrato nos termos em que foi celebrado" ${ }^{444}$.

Estamos de acordo com o posicionamento da referida autora. A recusa antecipada em adimplir - expressa ou tácita - pode dar-se tanto pela declaração de não cumprimento da obrigação total (o que caracterizaria um inadimplemento absoluto antecipado), como pela recusa em cumprir o contrato nos termos e na forma pactuada (o que chamaremos de mora antecipada). Percebe-se, assim, que não há a necessidade de que a recusa se dê de maneira absoluta, bastando que ela se volte aos termos previstos no contrato $^{445}$. Os efeitos do inadimplemento antecipado em um caso ou em outro serão tratados oportunamente.

Por ora, é importante destacar que poderá ocorrer uma mora antecipada (ou mora anterior ao termo) no caso de um determinado devedor cumprir antecipadamente,

\footnotetext{
${ }^{442}$ Em comentários sobre o artigo 72 da Convention on Contracts for the International Sales of Goods, que trata do inadimplemento antecipado, Schlechtriem \& Schwenzer asseveram que "o requisito do disposto no art. 72(1), de que a violação futura deve ser 'clara' (na versão em francês: manifeste), não se refere apenas ao conhecimento do credor das circunstâncias revelantes de uma dificuldade antecipada de cumprimento; 'claro' também enfatiza a necessidade de um alto grau de probabilidade de ocorrência, de fato, da violação". SCHLECHTRIEM, Peter; SCHWENZER, Ingeborg. Comentários à Convenção das Nações Unidas sobre Contratos de Compra e Venda Internacional de Mercadorias. Coordenação de tradução de Eduardo Grebler, Vera Fradera, César Guimarães Pereira. São Paulo: Editora Revista dos Tribunais. 2014. p. 1.081.

443 TERRA, Aline de Miranda Valverde. Inadimplemento anterior ao termo. Rio de Janeiro: Renovar. 2009. p. 166.

444 TERRA, Aline de Miranda Valverde. Inadimplemento anterior ao termo. Rio de Janeiro: Renovar. 2009. p. 168.

445 ANDRADE, Luis Tomás Alves de. O Inadimplemento Antecipado do Contrato no Direito Brasileiro. $R$. EMERJ, Rio de Janeiro, v. 14, n. 56, p. 145-172, out-dez. 2011, p. 154-155.
} 
mas de forma ou no lugar inadequados, a prestação que lhe competia ${ }^{446}$, ou demonstrar, com alto grau de probabilidade, que não cumprirá a obrigação na forma ou local pactuados. Exemplo: as partes celebram um contrato mediante o qual " $\mathrm{B}$ " deverá entregar um navio com determinadas especificações no prazo de 2 (dois) anos. Se, ao final de um ano e meio, "A", ao fazer uma vistoria para verificar o status da construção do barco, verificar que "B" está construindo um navio em desacordo com diversas das suas especificações, entendemos que estará caracterizada a mora antecipada.

Ressalvamos, todavia, que as manifestações - expressas ou tácitas - no sentido de não cumprir a prestação como pactuada não poderão caracterizar inadimplemento antecipado do contrato se versarem sobre aspectos periféricos, de pouca importância e que não atinjam diretamente o interesse típico e concreto do credor. É o que impõe a teoria do adimplemento substancial. O juiz deverá agir com bom senso no caso concreto para avaliar qual o impacto da manifestação expressa ou tácita do devedor diante da prestação devida e do interesse típico e concreto do credor.

Por fim, vale mencionar que, em algumas vezes, a configuração do suporte fático objetivo do inadimplemento antecipado não cria maiores dificuldades, não havendo dúvidas quanto à intenção de não adimplir ou quanto à impossibilidade de cumprimento no tempo, modo e lugar ajustados. É o caso, por exemplo do empreiteiro que, faltando apenas três meses para o termo de entrega das unidades imobiliárias, sequer iniciou as fundações da construção. A conduta omissiva do empreiteiro permite afirmar, com probabilidade próxima à certeza, sua intenção de não adimplir a prestação ${ }^{447}$.

No entanto, há muitos casos limite em que não é possível afirmar de imediato se a conduta do devedor conduzirá ao inadimplemento da obrigação no prazo pactuado,

\footnotetext{
${ }^{446}$ Nesse sentido, Gabriel Rocha Furtado afirma que "[...] ao menos em tese, não seria absurda a cogitação de uma mora anterior ao termo, tendo em conta a possibilidade de que um determinado devedor cumprisse antecipadamente, mas de forma ou no lugar inadequados, a prestação que lhe competia. Acaso o prazo tivesse sido estipulado em favor do devedor, poder-se-lhe-ia assim admitir que ele teria renunciado ao termo e, ao cumprir imperfeitamente, incorrido em mora (sanável até o momento em que o credor viesse a alegar a perda de utilidade)". FURTADO, Gabriel Rocha. Mora e Inadimplemento substancial. São Paulo: Atlas. 2014. p. 87.

${ }^{447} \mathrm{O}$ exemplo é de TERRA, Aline de Miranda Valverde. Inadimplemento anterior ao termo. Rio de Janeiro: Renovar. 2009. p. 179-180.
} 
que exigem um exame bastante cauteloso do caso concreto. Por exemplo, se o empreiteiro não tiver iniciado as fundações de uma obra de médio porte um ano antes do termo de entrega.

A nosso ver, somente se restar demonstrado pelo devedor (i) que o cumprimento no termo contratual é impossível; ou (ii) que embora possível, dependa de esforço extraordinário do devedor; ou (iii) que tornará a prestação inútil para o credor após o advento do termo, considera-se configurado o suporte fático do inadimplemento antecipado. Além dessas hipóteses, somente poderia ser cogitado risco de descumprimento, figura distinta do inadimplemento antecipado e que será analisada adiante.

\subsubsection{Inadimplemento antecipado por impossibilidade}

A segunda hipótese configuradora do inadimplemento antecipado é aquela na qual "o devedor coloca-se em determinada situação na qual fique inconteste a impossibilidade de cumprir a obrigação, ainda que não haja qualquer manifestação expressa sobre o desejo de renunciar ao contrato"

É o que se denomina manifestação do devedor no sentido de não poder adimplir, que ocorre nas situações em que o comportamento do devedor, comissivo ou omissivo, impossibilite desde logo a prestação. Nas palavras de Ruy Rosado Aguiar Júnior, “o incumprimento antecipado ocorrerá sempre que o devedor, beneficiado com um prazo, durante ele pratique atos que, por força da natureza ou da lei, faça impossível o futuro cumprimento" $" 449$.

Como exemplo de inadimplemento antecipado por impossibilidade pode ser mencionado o caso do cirurgião contratado para realizar um determinado procedimento cirúrgico em uma certa data. No entanto, apenas uma semana antes da data do procedimento, o cirurgião entra em contato com os hospitais da cidade para reservar o

\footnotetext{
${ }^{448}$ MARTINS, Raphael Manhães. Inadimplemento antecipado: perspectiva para a sua aplicação no Direito brasileiro. Revista Forense, Rio de Janeiro, v. 391, ano 103, mai./jun. 2007, p. 211.

449 AGUIAR JR., Ruy Rosado. Extinção dos contratos por incumprimento do devedor (resolução). Rio de Janeiro: Aide. 1991. p. 126-127.
} 
centro cirúrgico, mas verifica que não há disponibilidade para a data desejada em virtude da proximidade do dia escolhido. Nesse caso, o atraso na execução do dever secundário relativo ao agendamento do centro cirúrgico acabou por impossibilitar a realização da cirurgia nos termos pactuados ${ }^{450}$.

Outro exemplo de inadimplemento antecipado por impossibilidade é o caso do fabricante de jatos particulares que aliena para terceiro a aeronave objeto da alienação anterior, ou vende os equipamentos necessários à fabricação do jato ${ }^{451}$. Também pode ser citado o caso da incorporadora imobiliária que aliena para terceiro terreno em que ela se comprometeu a construir unidades habitacionais.

Mencione-se ainda o exemplo em que uma empresa se compromete a realizar um evento em um determinado espaço, mas poucos meses antes da data do evento inicia uma grande reforma no local, de maneira que o espaço não estará em condições de sediar a festa. Em todos esses casos, ao violar o dever de não agir de modo a obstaculizar o adimplemento da prestação, o devedor acaba por impossibilitar o cumprimento da prestação devida.

Diferentemente do caso da recusa, a impossibilidade de cumprir a prestação antes do termo contratual caracteriza-se não pelo elemento subjetivo (vontade de não adimplir), mas pelo elemento objetivo. A hipótese de inadimplemento antecipado por impossibilidade ressalta o fato de o devedor, por ato próprio, criar situação que impossibilitará a entrega da prestação devida ${ }^{452}$. Portanto, "no adimplemento antecipado por impossibilidade, não há quaisquer indagações sobre a intenção (dolo) do devedor em

\footnotetext{
${ }^{450}$ É uma adaptação do exemplo de TERRA, Aline de Miranda Valverde. Inadimplemento anterior ao termo. Rio de Janeiro: Renovar. 2009. p. 169.

${ }^{451}$ São adaptações dos exemplos de TERRA, Aline de Miranda Valverde. Inadimplemento anterior ao termo. Rio de Janeiro: Renovar. 2009. p. 161-172.

452 Destaque-se que, se a impossibilidade remonta à gênese da obrigação, não se deve pensar em inadimplemento antecipado, mas sim em nulidade do negócio jurídico. Caso a impossibilidade seja superveniente à origem do negócio, mas anterior ao termo ajustado, será possível vislumbrar o inadimplemento antecipado.
} 
colocar-se na posição de impossibilidade de prestar, mas apenas sobre a contribuição de sua culpa, exclusiva ou concorrente, para este resultado"453.

No inadimplemento antecipado por impossibilidade, o devedor se comporta, ao longo da relação obrigacional, em sentido manifestamente contrário ao cumprimento das obrigações contratuais por meio de uma série de condutas (omissivas ou comissivas) que culminarão, de maneira conclusiva, na impossibilidade de cumprimento da prestação devida $^{454}$. Daí porque Luis Tomás Alves de Andrade afirma que:

Com isso, percebe-se que o comportamento do devedor deve estar vinculado a uma possibilidade superveniente de se cumprir o pactuado, isto é, a conduta da contraparte deve, necessariamente, dar causa ao inadimplemento. Desse modo, excluem-se da quebra antecipada, por exemplo, as hipóteses do caso fortuito ou força maior, haja vista que, nesses casos, a superveniente impossibilidade de cumprimento não se vincula ao comportamento do devedor, e sim à fatores externos à relação obrigacional. ${ }^{455}$

Destaque-se que o suporte fático objetivo para a caracterização do inadimplemento antecipado por impossibilidade pressupõe não apenas a conduta do devedor, mas também o efeito que essa conduta produz sobre a prestação devida, qual seja, a impossibilidade (em sua acepção técnico-jurídica) ${ }^{456}$. É nesse sentido que a doutrina afirma que o comportamento do devedor deve ser tal que torne a execução do contrato definitivamente impossível.

O simples medo ou receio de que o devedor não venha a adimplir suas obrigações, ainda que existam indícios que fundamentem essas suposições, não é suficiente para a configuração do inadimplemento antecipado da obrigação ${ }^{457}$. Outrossim, a simples

\footnotetext{
${ }^{453}$ MARTINS, Raphael Manhães. Inadimplemento antecipado: perspectiva para a sua aplicação no Direito brasileiro. Revista Forense, Rio de Janeiro, v. 391, ano 103, mai./jun. 2007, p. 212.

${ }^{454}$ ANDRADE, Luis Tomás Alves de. O Inadimplemento Antecipado do Contrato no Direito Brasileiro. $R$. EMERJ, Rio de Janeiro, v. 14, n. 56, p. 145-172, out-dez 2011. p. 156.

${ }^{455}$ ANDRADE, Luis Tomás Alves de. O Inadimplemento Antecipado do Contrato no Direito Brasileiro. $R$. EMERJ, Rio de Janeiro, v. 14, n. 56, p. 145-172, out-dez. 2011, p. 157.

456 TERRA, Aline de Miranda Valverde. Inadimplemento anterior ao termo. Rio de Janeiro: Renovar. 2009. p. 169.

${ }^{457}$ MARTINS, Raphael Manhães. Inadimplemento antecipado: perspectiva para a sua aplicação no Direito brasileiro. Revista Forense, Rio de Janeiro, v. 391, ano 103, mai./jun. 2007, p. 212.
} 
dificuldade ou a impossibilidade temporária ${ }^{458}$ também não enseja a configuração do estado de não poder adimplir ${ }^{459}$, haja vista que, nesses casos, não haverá a definitividade e a certeza exigidas.

Nesse sentido, explica Ruy Rosado de Aguiar que "ficam excluídas a simples dificuldade e a impossibilidade temporária. A prática de atos contrários ao contrato e à declaração do devedor devem estar devidamente demonstradas e caracterizadas, criando uma situação que inevitavelmente levará ao descumprimento" ${ }^{460}$. Adotando o mesmo posicionamento, esclarece José Roberto de Castro Neves que "a mera dificuldade no futuro cumprimento ou o receio do credor de que não entregará a prestação não acarretam o inadimplemento antecipado" $" 461$.

Para que o inadimplemento antecipado esteja caracterizado, a impossibilidade de cumprimento da prestação devida deverá se dar de forma definitiva e diretamente ligada ao comportamento do devedor. ${ }^{462} \mathrm{~A}$ impossibilidade de cumprimento da obrigação deve ser inegável e irreparável, para o credor valer-se do instituto do inadimplemento antecipado. Caberá ao credor o ônus de demonstrar a impossibilidade para invocar a quebra antecipada $^{463}$.

Convém observar que o Código Civil contém dispositivo que trata do inadimplemento de obrigação de dar coisa certa, ao qual podem ser aplicadas as considerações feitas acima sobre o inadimplemento antecipado por impossibilidade. Tratase do artigo 234 do Código Civil, que dispõe que:

\footnotetext{
${ }^{458}$ Como exemplo de impossibilidade temporária pode ser mencionado o caso de promitente vendedor de unidade imobiliária que aliena o mesmo imóvel a terceiro com cláusula de retrovenda a ser executada antes do advento do termo da promessa. TERRA, Aline de Miranda Valverde. Inadimplemento anterior ao termo. Rio de Janeiro: Renovar. 2009. p. 177.

${ }^{459}$ AGUIAR JR., Ruy Rosado. Extinção dos contratos por incumprimento do devedor (resolução). Rio de Janeiro: Aide. 1991. p. 127.

${ }^{460}$ AGUIAR JÚNIOR, Ruy Rosado de. Extinção dos contratos por incumprimento do devedor. 2. Ed. Rio de Janeiro: AIDE. 1991. p.127.

${ }^{461}$ NEVES, José Roberto de Castro. O direito das obrigações. Rio de Janeiro: GX. 2008. p. 355.

${ }^{462}$ ANDRADE, Luis Tomás Alves de. O Inadimplemento Antecipado do Contrato no Direito Brasileiro. $R$. EMERJ, Rio de Janeiro, v. 14, n. 56, p. 145-172, out-dez. 2011, p. 157.

${ }^{463}$ ANDRADE, Luis Tomás Alves de. O Inadimplemento Antecipado do Contrato no Direito Brasileiro. $R$. EMERJ, Rio de Janeiro, v. 14, n. 56, p. 145-172, out-dez. 2011, p. 159.
} 
Art. 234. Se no caso do artigo antecedente ${ }^{464}$, a coisa se perder, sem culpa do devedor, antes da tradição ou pendente a condição suspensiva, fica resolvida a obrigação para ambas as partes; se a perda resultar de culpa do devedor, responderá este pelo equivalente e mais perdas e danos.

$\mathrm{Na}$ modalidade de obrigação de dar coisa certa, "tem o devedor o dever jurídico de entregar ou de restituir a coisa determinada, bem como os seus acessórios, salvo se o contrário resultar do título obrigacional ou das circunstâncias do caso, segundo se depreende do art. 233 do nosso CC" ${ }^{465}$. Conforme explica Álvaro Villaça Azevedo, nesse tipo de obrigação é necessário que haja a entrega ou a restituição do objeto, ou seja, a tradição da coisa, pois a simples convenção das partes, em nosso Direito, não transfere o domínio dos bens"466. A transferência do domínio dos móveis faz-se pela tradição, pela entrega do objeto, e dos imóveis pela tradição solene, pelo registro, na matrícula, do título aquisitivo, no Cartório de Registro de Imóveis competente.

Pode ocorrer que, por ocasião da entrega da coisa, ela tenha se "perdido", com culpa ou sem culpa do devedor. Em linguagem jurídica, por "perda" quer-se dizer perecimento total do objeto ou desaparecimento patrimonial ${ }^{467}$. Caio Mário da Silva Pereira explica que "o conceito de perda, para o direito, é lato, e tanto abrange o seu desaparecimento total (interitus rei), quanto ainda o de deixar de ter suas qualidades essenciais, ou de tornar indisponível, ou situar-se em lugar que se tornou inatingível, ou ainda de confundir-se com outra" 468 .

É a situação em que a coisa perece, desaparece ou se deteriora antes da tradição ou da satisfação da condição suspensiva que se aplica o artigo 234 do Código Civil, conforme se observa dos comentários de Álvaro Villaça Azevedo:

\footnotetext{
${ }^{464} \mathrm{O}$ artigo 233 do Código Civil dispõe que "a obrigação de dar coisa certa abrange os acessórios dela embora não mencionados, salvo se o contrário resultar do título ou das circunstâncias do caso".

465 Álvaro Villaça Azevedo conceitua as obrigações de dar coisa certa da seguinte forma: AZEVEDO, Álvaro Villaça. Teoria geral das obrigações: responsabilidade civil. 10. ed. São Paulo: Atlas, 2004. p. 57.

466 Álvaro Villaça Azevedo conceitua as obrigações de dar coisa certa da seguinte forma: AZEVEDO, Álvaro Villaça. Teoria geral das obrigações: responsabilidade civil. 10. ed. São Paulo: Atlas. 2004. p. 57.

467 AZEVEDO, Álvaro Villaça. Teoria geral das obrigações: responsabilidade civil. 10. ed. São Paulo: Atlas. 2004. p. 58.

468 PEREIRA, Caio Mário da Silva. Instituições de Direito Civil. vol. II. 20. ed. Rio de Janeiro: Forense, 2005. p. 51.
} 
Pode ocorrer, entretanto, que, por ocasião da entrega da coisa, tenha ela perecido ou se deteriorado, com culpa ou sem culpa do devedor. [...]

Ocorrendo culpa do devedor, em face do perecimento do objeto, tem o credor direito a receber o equivalente e mais perdas e danos, segundo estabelece o art. 234, segunda parte, do CC. Quando a lei se refere ao termo equivalente, quer mencionar o equivalente em dinheiro, de maneira que, havendo o perecimento, a perda total da coisa, com culpa do devedor, deve este entregar a seu credor o equivalente em dinheiro, que corresponde ao valor do objeto perecido, mais as perdas e danos, que denotarão o prejuízo sofrido. ${ }^{469}$

A nosso ver, a situação em que o devedor perder a coisa antes da tradição ou do implemento da condição suspensiva por sua culpa se enquadra perfeitamente no conceito de inadimplemento antecipado de obrigação por impossibilidade. Com efeito, a hipótese prevista na parte final do caput do artigo 234 do Código Civil trata justamente de uma impossibilidade superveniente (perda da coisa) que foi provocada por conduta culposa do devedor antes do termo.

Apesar de o artigo 234 do Código Civil não se referir expressamente ao termo contratual, mas apenas à condição suspensiva, considera-se que não há motivo para se lhe afastar a incidência ${ }^{470}$. Na realidade, o dispositivo em comento se aplica com ainda mais razão se houver termo, uma vez que, neste caso e ao contrário da condição suspensiva, o credor já adquiriu o direito à tradição, embora ainda não possa exigi-la ${ }^{471}$.

O seguinte exemplo formulado por Ruy Rosado de Aguiar Júnior serve bem para ilustrar que o artigo 234 do Código Civil pode ser considerado uma hipótese de inadimplemento antecipado por impossibilidade:

"A" contrata permutar o seu automóvel, que desde logo transfere a "B", devendo
deste receber, dentro de alguns dias, uma camioneta, a qual vem a ser destruída
em incêndio, antes da data aprazada para a entrega. Se o incêndio resultou de
caso fortuito, para o qual não concorreu culposamente "B", nem negligenciou ele
na produção do evento ou na causação do resultado, a relação obrigacional está
extinta $e x$ vi legis, "resolvida a obrigação para ambas as partes" (art. 865 do

${ }^{469}$ AZEVEDO, Álvaro Villaça. Teoria geral das obrigações: responsabilidade civil. 10. ed. São Paulo: Atlas. 2004. p. 58-59.

${ }^{470}$ Gustavo Tepedino, Heloisa Helena Barbosa e Maria Celina Bodin, após discorrerem sobre o artigo 234 do Código Civil, afirmam que "o mesmo raciocínio se aplica a um negócio realizado a termo". TEPEDINO, Gustavo; BARBOZA, Heloisa Helena; MORAES, Maria Celina Bodin de. Código Civil interpretado conforme a Constituição da República. v. I. 2. ed. rev. e atual. Rio de Janeiro: Renovar. 2007. p. 502.

471 TERRA, Aline de Miranda Valverde. Inadimplemento anterior ao termo. Rio de Janeiro: Renovar. 2009. p. 173. 
Código Civil). Se o incêndio decorreu de ato imputável a "B", que teria sido negligente no cuidado dispensado ao veículo, a relação não está extinta ipso jure: o credor pode dar execução ao contrato, mantendo a sua prestação (transferência do automóvel a "B") e exigir de "B" o equivalente da camioneta destruída, mais perdas e danos (art. 865, $2^{\mathrm{a}}$ parte). Optando por resolver a obrigação, em face da culpa de "B", o credor tem o direito de obter a restituição de seu automóvel, mais perdas e danos. ${ }^{472}$

Com efeito, se o devedor agiu com culpa ao deixar que a sua camioneta fosse destruída em incêndio, ele claramente praticou ato contrário ao cumprimento da obrigação antes do termo contratual, e impossibilitou, antecipadamente, o cumprimento da prestação devida (entrega da camioneta em boas condições). Trata-se, inegavelmente, de caso que satisfaz o suporte fático objetivo do inadimplemento antecipado.

\subsubsection{Elemento subjetivo}

Nesse ponto, será examinado se a culpa do devedor é pressuposto para a caracterização do inadimplemento antecipado. Como exposto no primeiro capítulo, a doutrina tradicional, que ainda parece ser a majoritária, entende que o inadimplemento está intrinsecamente relacionado à ideia de culpa (em sentido amplo). Para essa parcela da doutrina, o inadimplemento sempre decorreria da violação de um dever contratual ou legal que corresponda a uma conduta faltosa de uma das partes contratantes.

Baseando-se nesta premissa, os autores ${ }^{473}$ que escrevem sobre o tema do inadimplemento antecipado também afirmam que o inadimplemento antecipado somente se caracteriza se houver uma conduta intencional ou desidiosa do devedor. Nessa visão, sempre se deve examinar se foi a culpa (em sentido amplo) na ação ou omissão do devedor que deu causa ao inadimplemento antecipado da obrigação. É esse o posicionamento de Luis Tomás Alves de Andrade:

472 AGUIAR JR., Ruy Rosado. Extinção dos contratos por incumprimento do devedor (resolução). Rio de Janeiro: Aide. 1991. p. 103.

473 TERRA, Aline de Miranda Valverde. Inadimplemento anterior ao termo. Rio de Janeiro: Renovar, 2009. p. 182; LABOURIAU, Miguel. Algumas considerações sobre o inadimplemento antecipado no direito brasileiro. Revista Trimestral de Direito Civil, v. 42, abr./jun. 2010, Padma, Rio de Janeiro, p. 114-115; ANDRADE, Luis Tomás Alves de. O Inadimplemento Antecipado do Contrato no Direito Brasileiro. $R$. EMERJ, Rio de Janeiro, v. 14, n. 56, p. 145-172, out-dez. 2011, p. 157. 
Por fim, para que esteja configurado o inadimplemento antecipado - seja na hipótese de recusa expressa, seja na de comportamento concludente do devedor há que se verificar não apenas os elementos objetivos acima elencados, mas também a existência do elemento subjetivo, qual seja, a culpa do devedor. ${ }^{474}$

A doutrina costuma afirmar que, na declaração expressa de não querer adimplir, identifica-se o dolo do devedor em não querer adimplir. Em relação aos demais suportes fáticos objetivos, a doutrina considera suficiente para configurar $\mathrm{o}$ inadimplemento antecipado a conduta culposa do devedor. Em consequência, no que tange ao comportamento do devedor que impossibilite ou torne inútil o cumprimento da obrigação no prazo pactuado, entende-se que não é necessário que o devedor objetive, com aquela conduta, inadimplir a obrigação; basta examinar se, com sua conduta culposa, ele contribuiu para o resultado ${ }^{475}$.

No entanto, conforme discutido no primeiro capítulo, entendemos que nem sempre o inadimplemento resulta de uma imputabilidade subjetiva (culposa), existindo diversos casos de imputação objetiva (independentemente de culpa). A nosso ver, a culpa não é elemento essencial e indispensável do inadimplemento. O que importa é existir um nexo de imputação, uma razão de ser da atribuição da responsabilidade a uma determinada pessoa, pelos danos ocasionados ao patrimônio ou a outrem, que pode ser a culpa, a cláusula geral de responsabilidade objetiva prevista no art. 927, § único, do Código Civil, ou uma previsão legal ou contratual de responsabilidade objetiva.

Por adotarmos essa premissa, entendemos que para o inadimplemento antecipado, assim como acontece no inadimplemento que se configura após o advento do termo, basta um nexo de imputação, que pode ser subjetivo ou objetivo, não sendo necessária sempre e necessariamente a culpa do devedor. O tipo de nexo de imputação dependerá da relação obrigacional específica, da legislação e das cláusulas contratuais.

\footnotetext{
${ }^{474}$ ANDRADE, Luis Tomás Alves de. O Inadimplemento Antecipado do Contrato no Direito Brasileiro. $R$. EMERJ, Rio de Janeiro, v. 14, n. 56, p. 145-172, out-dez. 2011, p. 157.

${ }^{475}$ TERRA, Aline de Miranda Valverde. Inadimplemento anterior ao termo. Rio de Janeiro: Renovar. 2009. p. 182.
} 
Por exemplo, em um contrato de compra e venda de unidades imobiliárias em construção que seja regido pelo Código de Defesa do Consumidor, que prevê a responsabilidade objetiva do fornecedor, não é necessário comprovar a culpa da construtora para caracterizar o inadimplemento antecipado caso se constate, com probabilidade próxima à certeza, que o apartamento não será entregue na data pactuada em virtude de um caso fortuito interno (ex: chuvas intensas que provocaram o atraso da obra). Assim, tal como ocorre no inadimplemento posterior ao termo, o inadimplemento antecipado não se verifica somente se houver culpa de uma das partes contratantes.

\subsection{Distinção entre inadimplemento antecipado e risco de descumprimento da prestação}

Todas as situações expostas no item anterior servem de suporte fático objetivo à configuração do inadimplemento antecipado, uma vez que, antes do advento do termo, resta demonstrado que o devedor não adimplirá no prazo pactuado, a impossibilidade ou a inutilidade do cumprimento da prestação, a suscitar a produção de determinados efeitos ${ }^{476}$.

Contudo, há outras circunstâncias que também se verificam anteriormente ao termo e que, apesar de ainda não importarem no inadimplemento da prestação, colocam em risco o seu cumprimento, requerendo resposta do ordenamento jurídico para que a probabilidade não se torne certeza.

Apesar de o objeto deste estudo ser o inadimplemento antecipado, tratar-se-á brevemente do risco de descumprimento para melhor caracterizar aquele. Isso porque, algumas vezes, a falta de rigor na identificação do suporte fático objetivo do inadimplemento antecipado permite nele incluir situações que não caracterizam um inadimplemento em si, mas apenas um alto risco do descumprimento da prestação devida. No entanto, essa postura acrítica acaba por ensejar a produção de efeitos de um pelo outro, de modo a descaracterizar os institutos ${ }^{477}$.

\footnotetext{
${ }^{476}$ Para análise dos efeitos do inadimplemento antecipado, confira-se o terceiro capítulo.

477 TERRA, Aline de Miranda Valverde. Inadimplemento anterior ao termo. Rio de Janeiro: Renovar. 2009. p. 184.
} 
Em linhas gerais, o risco de descumprimento diz respeito àquelas situações em que, apesar de não configurado o efetivo inadimplemento antecipado, existe uma considerável probabilidade de, no futuro, o devedor não conseguir adimplir a obrigação no tempo, modo e lugar pactuados, o que autoriza que o credor aja de imediato no sentido de proteger o seu crédito.

Como exemplos de situações de risco de descumprimento podem ser mencionados os casos da empresa de construção civil que, um ano e meio antes do termo ajustado para a entrega da obra, sequer iniciou as escavações necessárias para a colocação das fundações do edifício; o devedor que, contratado para fabricar móveis para o credor, começa a alienar as máquinas necessárias à produção ${ }^{478}$; ou o construtor de navios com apenas um estaleiro que promete construir um iate até $1^{\circ}$ de maio, mas pouco tempo depois o seu cliente descobre que o construtor se comprometeu a entregar um iate para uma terceira pessoa no mesmo período ${ }^{479}$.

O principal traço distintivo entre as figuras do inadimplemento antecipado e do risco de descumprimento está no grau de certeza que se tem de que o devedor não pretende adimplir ou não conseguirá adimplir no termo pactuado entre as partes. $\mathrm{O}$ inadimplemento antecipado pressupõe uma probabilidade próxima à certeza, deve ser inequívoco e em termos absolutos; ao passo que o risco de descumprimento somente exige uma alta probabilidade de que o devedor não pretende ou conseguirá adimplir.

As lições de Judith Martins-Costa são bastante elucidativas nesse sentido:

A certeza acerca do inadimplemento é o segundo requisito. Conseqüência tão
grave quanto o é a resolução contratual não se coaduna com a mera especulação,
a dúvida acerca de um possível inadimplemento: o incumprimento deve ser
"inequívoco" e posto em 'termos absolutos', isto é, insuscetíveis de dúvidas.
Seja explícita ou implícita a recusa em adimplir, deve haver certeza, pois "le
refus n'autorise acune anticipation s'il est ambigu". Evidentemente, pondera José

${ }^{478}$ Os exemplos são de TERRA, Aline de Miranda Valverde. Inadimplemento anterior ao termo. Rio de Janeiro: Renovar. 2009. p. 187.

${ }^{479} \mathrm{O}$ exemplo é de VILLELA, João Baptista et al. Princípios UNIDROIT relativos aos Contratos Comerciais Internacionais/2004 [versão em língua portuguesa]. São Paulo: Quartier Latin. 2009. p. 240. 
Roberto de Castro Neves, "a mera dificuldade no futuro cumprimento ou receio do credor de que o devedor não entregará a prestação não acarretam o inadimplemento antecipado. Deve haver a certeza de que, pelas circunstâncias atuais, o devedor não estará apto a cumprir o seu dever obrigacional”. Lembra o autor, com razão, em que as situações em que não há certeza, mas tão-somente uma "alta probabilidade de inadimplemento, antevista pelo credor", escapam à esfera do Inadimplemento Antecipado, sendo regidas pelo art. 477, CC/02 (LGL/2002/400) (Exceção de Inseguridade). Em outras palavras é o que na doutrina francesa refere Laithier, mencionando a existência de uma "situação inequívoca", manifesta, não sendo suficiente que o credor tema o futuro inadimplemento. ${ }^{480}$

Esse entendimento doutrinário de que a probabilidade - ou mesmo a alta probabilidade - de inadimplemento não autoriza a caracterização da figura do inadimplemento antecipado, mas tão-somente do risco de inadimplemento, também encontra acolhida no direito estrangeiro:

In order for the Article to apply it must be "clear" that the debtor is not willing or able to perform at the due date. An express repudiation by the debtor will satisfy this requirement but even in the absence of a repudiation the circumstances may make the situation clear. If the debtor's behavior merely engenders doubt as to willingness or ability to perform, the creditor's remedy is to demand an assurance of performance. ${ }^{481}$

O risco de descumprimento dá ensejo à figura da "exceção de inseguridade",482, que autoriza uma parte, quando estiver diante de uma situação em que tenha alta dúvida de que a outra parte conseguirá cumprir a sua obrigação, a cessar ou reter a sua obrigação até que a outra efetue a sua, ou preste caução suficiente. É nesse sentido que se manifesta Cristiano Zanetti:

Certo risco é inerente a todo e qualquer contrato. Não é dado nem desejável que a legislação o elimine. Caso contrário, sequer haveria interesse em contratar, ou seja, em planejar, em dispor para o futuro. Corrigir excessos, sim, é tarefa do direito. $[\ldots]$

480 MARTINS-COSTA, Judith H. A recepção do incumprimento antecipado no direito brasileiro: configurações e limites. Revista dos Tribunais, v. 885, p. 33.

${ }^{481}$ VON BAR, Christian; CLIVE, Eric. Principles, Definitions and Mode, Rules of European Private Law. Draft Common Frame of Reference (DCRF). Full Edition. v. I. Sellier. p. 509. Em tradução livre: "Para que o Artigo seja aplicável deve estar 'claro' que o devedor não está disposto ou capaz de cumprir com as obrigações assumidas até a data de seu adimplemento. Um repúdio expresso pelo devedor irá satisfazer esse requisito, mas, mesmo na ausência do repúdio, as circunstâncias podem tornar a situação clara. Se o comportamento do devedor meramente gera dúvidas quanto à vontade ou capacidade para cumprimento, o remédio do credor é exigir uma garantia de performance."

${ }^{482}$ MIRANDA, Pontes de. Tratado de direito privado. T. XXVI. Rio de Janeiro: Editor Borsoi. 1959. p. 110. 
Pode ocorrer, entretanto, que a situação patrimonial da parte que deve prestar depois comprometa ou torne duvidosa a execução do contrato. Nessa hipótese, a parte que deve cumprir em primeiro lugar pode recusar-se a executar sua prestação até que a outra satisfaça sua obrigação ou, pelo menos, forneça garantia suficiente. Trata-se da chamada exceção de inseguridade, cujo objetivo é evitar riscos extraordinariamente impostos à parte. ${ }^{483}$

O Código Civil prevê, de maneira expressa, um único suporte fático objetivo do risco de descumprimento, que é a deterioração patrimonial do devedor, capaz de comprometer ou tornar duvidosa a prestação à qual se obrigou. O suporte fático do risco de descumprimento foi previsto no artigo 477 do Código Civil ${ }^{484}$, segundo o qual, a partir do momento em que a parte obrigada a prestar em primeiro lugar toma conhecimento de diminuição no patrimônio da outra parte que a leve a crer que o outro contratante não terá condições de cumprir a obrigação a que se obrigou, aquela fica autorizada por lei a cessar ou reter a sua obrigação até que o segundo efetue a sua, ou preste caução suficiente ${ }^{485}$.

O risco de descumprimento em decorrência de deterioração patrimonial também se encontra tipificado no artigo 495 do Código Civil ${ }^{486}$, aplicável aos contratos de compra e venda em que, não obstante o prazo ajustado para pagamento, o comprador se

${ }^{483}$ ZANETTI, Cristiano de Souza. Exceção de Contrato não Cumprido. In: MORRIS, Amanda Zoe; barroso, Lucas Abreu (Coord.). Direito dos contratos. Orientação de Giselda M. F. Novaes Hironaka. São Paulo: Editora Revista dos Tribunais. 2008. p. 222.

484 “Art. 477. Se, depois de concluído o contrato, sobrevier a uma das partes contratantes diminuição em seu patrimônio capaz de comprometer ou tornar duvidosa a prestação pela qual se obrigou, pode a outra recusarse à prestação que lhe incumbe, até que aquela satisfaça a que lhe compete ou dê garantia bastante de satisfazê-la."

${ }^{485}$ Interessante a análise sobre o artigo 477 do Código Civil: "O dispositivo exatamente seguinte, do artigo 477, cuida da hipótese de a parte temer um futuro - e ameaçador - inadimplemento. A lei deve ser inteligente. Cumpre ao legislador antecipar-se à situação fática, regulando a hipótese para que, se e quando ela ocorrer, já exista a norma pertinente. Imagine-se a seguinte situação: depois de celebrado um contrato, no qual cada uma das partes deva cumprir certas obrigações, uma delas tem seu patrimônio duramente afetado. A parte que manteve sua situação financeira, então, encara o dilema de cumprir a sua prestação, e não receber a contraprestação, ou, de outro lado, ficar inadimplente, mas, ao menos, proteger seu patrimônio (pois se cumprisse a sua parte, há o risco de jamais receber a contraprestação, ou mesmo uma reparação pelo inadimplemento da contraparte). Pensando nessa situação, o legislador estabeleceu a regra do artigo 477 do Código Civil, segundo a qual, em casos como o narrado acima - de uma das partes sofrer sensível decréscimo patrimonial -, a parte interessada possa pedir a outra que cumpra, desde logo, a sua prestação, ou forneça garantias de que irá satisfazê-la. Trata-se, claro, de uma medida acautelatória. A parte de uma relação obrigacional, antes de cumprir a sua prestação e antes de receber seu pagamento, invocando o artigo 477 do Código Civil, requer da contraparte o pagamento antecipado, ou o oferecimento da garantia, quando tiver aquela sofrido considerável perda patrimonial, que torne duvidosa a sua solvência." (NEVES, José Roberto de Castro. As Garantias do Cumprimento da Obrigação. Revista da EMERJ, v. 11, no 44, 2008. p. 189).

486 “Art. 495. Não obstante o prazo ajustado para o pagamento, se antes da tradição o comprador cair em insolvência, poderá o vendedor sobrestar a entrega da coisa, até que o comprador lhe dê caução de pagar no tempo ajustado.” 
torna insolvente antes da tradição, e no artigo $590^{487}$, aplicável aos contratos de mútuo, quando o mutuário sofrer notória mudança em sua situação econômica antes do prazo de vencimento.

Com relação ao risco de descumprimento, Caio Mário da Silva Pereira pondera que a hipótese fática objetiva prevista expressamente pelo Código Civil é a considerável diminuição patrimonial do devedor:

\begin{abstract}
Consequência, ainda, do mesmo princípio da interligação orgânica das prestações é a concessão feita pelo Código (art. 475) (sic), ao contratante que tiver de fazer a sua prestação em primeiro lugar, outorgando-lhe o direito de recusá-la se, depois de concluído o contrato, sobrevier ao outro contratante alteração nas condições econômicas, capaz de comprometer ou tornar duvidosa a prestação a que se obrigou. É claro que a medida é excepcional, pois que, ajustadas prestações combinadas, não justifica a recusa de um o fato de não haver ainda prestado o outro. É o próprio contrato que o estabelece, mas não quer a ordem jurídica que aquele dos contratantes que tem de pagar primeiro fique exposto a risco anormal. Desde que saiba, ou tenha condições plausíveis de presumir (protesto de título, pedido de moratória ou de concordata, etc), que a diminuição patrimonial do outro faça duvidar da contraprestação esperada, cessará o pagamento ou reterá a execução, até que se lhe dê a solução devida, ou a garantia suficiente de que será efetivada no momento oportuno.
\end{abstract}

Pontes de Miranda afirma que os pressupostos para a aplicação da exceção de inseguridade são a bilateralidade do contrato e a diminuição do patrimônio da outra parte contratante, a ponto de comprometer ou tornar duvidosa a prestação à qual se obrigou, a qual deverá ser posterior à conclusão do contrato. O autor complementa que a previsão do artigo 477 do Código Civil - o artigo 1.092 do Código Civil de 1916 tinha redação idêntica - “não [...] trata de pretensão à prestação antecipada (em relação à do outro figurante); ou à caução; trata-se de exceção. Ao outro figurante é que cabe escolher entre prestar antecipadamente (= ao mesmo tempo que o teria de prestar antes), ou dar caução". Afirma, ainda, que se o obrigado a prestar em primeiro lugar opõe exceção de inseguridade quando não estão satisfeitos os seus pressupostos, deverá responder por perdas e danos ${ }^{489}$.

\footnotetext{
487 "Art. 590. O mutuante pode exigir garantia da restituição, se antes do vencimento o mutuário sofrer notória mudança em sua situação econômica."

${ }^{488}$ PEREIRA, Caio Mário da Silva. Instituições de direito civil. v. III. Rio de Janeiro: Forense. 2006. p. 161.

${ }^{489}$ MIRANDA, Pontes de. Tratado de Direito Privado. T. XXVI. Rio de Janeiro: Editor Borsoi. 1959. p. 109-111.
} 
A perda patrimonial que caracteriza o risco de descumprimento deve ser superveniente à formação do contrato e grave o suficiente para suscitar dúvida quanto à efetiva possibilidade de adimplemento da prestação ${ }^{490}$. Não basta a mera desconfiança de que o patrimônio da outra parte foi afetado por perda superveniente; é necessário demonstrar a presença de indícios satisfatórios que demonstrem dúvida significativa quanto ao risco de adimplemento da contraprestação. Por outro lado, embora o artigo 495 do Código Civil se refira à insolvência do devedor, entende-se que não é necessária a decretação de falência ou de insolvência civil do devedor, mas um estado de “insolvabilidade", um estado patrimonial que permita presumir a insolvência ${ }^{491}$. É o que observa Cristiano Zanetti:

\begin{abstract}
É oportuno ressaltar que a diminuição do patrimônio deve ser suficiente a ponto de pôr em risco a execução da prestação devida (Pontes de Miranda, Tratado de direito privado, t. XXVI, p. 110). Não basta a mera oscilação negativa que, aliás, é frequente no patrimônio de toda e qualquer pessoa jurídica que opera no mercado. Exige-se, ademais, que a diminuição patrimonial seja demonstrada. $\mathrm{Na}$ hipótese ventilada, seria insuficiente a apresentação de notícias jornalísticas que pusessem em dúvida a idoneidade financeira da sociedade artística, a menos que fossem corroboradas por outro tipo de evidência. Não bastaria igualmente a superveniência de execuções de empréstimo não afetasse de modo importante o patrimônio da sociedade. A exceção de inseguridade serve a proteger a parte somente das flutuações patrimoniais excepcionais. ${ }^{492}$
\end{abstract}

É importante destacar que nenhum dos três dispositivos do Código Civil que tratam do risco de inadimplemento impõe verificar se houve culpa da parte que sofreu abalo patrimonial. O objetivo do legislador nesses dispositivos não foi de punir o

\footnotetext{
${ }^{490}$ No mesmo sentido, Cristiano de Sousa Zanetti afirma que "os pressupostos de oposição da exceção de inseguridade foram estudados à saciedade pela doutrina. De um lado, a diminuição do patrimônio deve ser bastante a pôr em risco a execução da prestação prometida. Não basta a mera oscilação negativa que, aliás, é frequente no patrimônio de toda e qualquer pessoa jurídica. A exceção de inseguridade protege a parte apenas das flutuações patrimoniais excepcionais. De outro, a exceção somente pode ser manejada se a diminuição patrimonial se der após a conclusão do contrato. Não há espaço para invocá-la, portanto, se o patrimônio do devedor comprometer a execução do avençado desde a celebração do negócio. A exceção protege o contratante de uma circunstância bastante específica. Não serve, porém, para eximi-lo do ônus de se informar a respeito da situação patrimonial da parte contrária". ZANETTI, Cristiano de Souza. Inadimplemento Antecipado da Obrigação Contratual. In: CELLI JUNIOR, Umberto; BASSO, Maristela; AMARAL JÚNIOR, Alberto do (Coord). Arbitragem e comércio internacional: estudos em homenagem a Luiz Olavo Baptista. São Paulo: Quartier Latin. 2013. p. 312.

${ }^{491}$ TERRA, Aline de Miranda Valverde. Inadimplemento anterior ao termo. Rio de Janeiro: Renovar. 2009. p. 186.

${ }^{492}$ ZANETTI, Cristiano de Souza. Exceção de Contrato não Cumprido. In: MORRIS, Amanda Zoe; BARROSO, Lucas Abreu (Coord.). Direito dos contratos. Orientação de Giselda M. F. Novaes Hironaka. São Paulo: Editora Revista dos Tribunais. 2008. p. 222-223.
} 
contratante, mas apenas proteger o equilíbrio contratual e minimizar o risco de inadimplemento $^{493}$.

Embora o Código Civil tenha previsto a diminuição patrimonial como a única hipótese caracterizadora do risco de descumprimento, parcela da doutrina ${ }^{494}$ entende que também é possível aplicar a figura da "exceção de inseguridade" para outras situações em que haja grave dúvida quanto à possibilidade do devedor de cumprir a prestação devida. Nesse sentido, a V Jornada de Direito Civil do Conselho de Justiça Federal/STJ aprovou o Enunciado 438: “a exceção de inseguridade, prevista no artigo 477, também pode ser oposta à parte cuja conduta põe manifestamente em risco a execução do programa contratual."

Não obstante a sua redação, consideramos que o exame do artigo 477 do Código Civil à luz do princípio da boa-fé objetiva permite concluir que, caso o comportamento do devedor coloque em risco (com alta probabilidade) o adimplemento contratual, o credor poderá se valer das medidas previstas no referido dispositivo legal, exigindo que o devedor cumpra a sua obrigação antecipadamente ou preste garantia idônea.

É contra o padrão de lealdade e probidade imposto pela boa-fé objetiva uma parte ser obrigada a cumprir a sua prestação se a outra colocou em grave risco o cumprimento da obrigação. A função restritiva de direitos da boa-fé veda que a parte faltosa pretenda a execução da prestação alheia, ainda que, em princípio, os termos

\footnotetext{
${ }^{493}$ TERRA, Aline de Miranda Valverde. Inadimplemento anterior ao termo. Rio de Janeiro: Renovar. 2009. p. 186.

${ }^{494}$ Neste sentido: SCHREIBER, Anderson. A tríplice transformação do adimplemento. Adimplemento substancial, inadimplemento antecipado e outras figuras. Revista Trimestral de Direito Civil. Rio de Janeiro, v. 32, out./dez 2007, p. 12-13; ZANETTI, Cristiano de Souza. Inadimplemento Antecipado da Obrigação Contratual. In: CELLI JUNIOR, Umberto; BASSO, Maristela; AMARAL JÚNIOR, Alberto do (Coord). Arbitragem e comércio internacional: estudos em homenagem a Luiz Olavo Baptista. São Paulo: Quartier Latin. 2013. p. 318; TERRA, Aline de Miranda Valverde. Inadimplemento anterior ao termo. Rio de Janeiro: Renovar. 2009. p. 187.
} 
avençados lhe autorizem. Trata-se de um exercício inaceitável de posição jurídica qualificado pela doutrina como tu quoque ${ }^{495}$.

A nosso ver, é perfeitamente possível estender a aplicação da figura do risco de descumprimento prevista no artigo 477 do Código Civil para casos de omissão ou retardo dos deveres secundários de prestação, da violação dos deveres de conduta ou da perda da habilidade necessária para o adimplemento da prestação, que tornem provável o inadimplemento no tempo, modo e lugar pactuado entre as partes. Ressalve-se, todavia, que o risco de descumprimento deve se referir à parcela substancial da prestação devida, de modo a ser capaz de torná-la impossível ou inútil para o credor $^{496}$.

Valemo-nos do contrato de empreitada para exemplificar a aplicação do referido dispositivo legal. Uma pessoa encomenda a construção de um navio a um certo empreiteiro, proprietário de um único estaleiro. O prazo de entrega do navio é estabelecido para o dia $1^{\circ}$ de maio. Logo em seguida, o contratante recebe a informação de que o empreiteiro se comprometeu a construir um barco para outrem no mesmo período. Se confirmada a notícia, ele poderá suspender a execução da respectiva prestação, até que o empreiteiro lhe apresente garantias de que poderá entregar o navio dentro do prazo ${ }^{497}$.

Nessa visão, a figura do risco de descumprimento prevista no artigo 477 do Código Civil poderia ser entendida genericamente como a situação em que a conduta de uma das partes de um negócio jurídico submete a risco o fiel cumprimento da prestação devida, ocasião em que a parte inocente pode, desde logo, suspender o cumprimento de sua

\footnotetext{
495 A esse respeito, Cristiano de Sousa Zanetti afirma que: "caso o comportamento do contratante ponha em risco a observância do programa contratual, não se afigura conforme a exigência de lealdade permitir que se pretenda o cumprimento da prestação alheia antes de executar aquilo a que se obrigou ou, ao menos, de oferecer garantia idônea de que o fará." ZANETTI, Cristiano de Souza. Inadimplemento Antecipado da Obrigação Contratual. In: CELLI JUNIOR, Umberto; BASSO, Maristela; AMARAL JÚNIOR, Alberto do (Coord). Arbitragem e comércio internacional: estudos em homenagem a Luiz Olavo Baptista. São Paulo: Quartier Latin. 2013. p. 319.

${ }^{496}$ TERRA, Aline de Miranda Valverde. Inadimplemento anterior ao termo. Rio de Janeiro: Renovar. 2009. p. 187-188.

497 O exemplo é de VILLELA, João Baptista et al. Princípios UNIDROIT Relativos aos Contratos Comerciais Internacionais/2004 [versão em língua portuguesa]. São Paulo: Quartier Latin. 2009. p. 240.
} 
respectiva prestação ou tomar as medidas necessárias para cumprir a prestação devida no prazo pactuado $^{498}$.

Destaque-se que a mera desconfiança do credor quanto à possibilidade do devedor adimplir não é suficiente para a caracterização do risco de descumprimento. Deve restar objetivamente comprovado que o risco de descumprimento existe. A esse respeito, Pontes de Miranda sugere que o critério para apurar o risco de descumprimento no caso concreto "é o do tráfico, e não o individual do devedor-credor" 499 , ou seja, que deve ser adotado um critério objetivo, de maneira a refletir o que usualmente acontece.

Entretanto, entende-se que o critério para verificar o risco de descumprimento também deve levar em consideração as características do devedor, do mercado em que o devedor atua e do tipo contratual. Por exemplo, tratando-se de empresa de construção civil de grande porte, renomada no mercado, detentora de moderna tecnologia, deve-se analisar o que normalmente acontece quando empresas do mesmo porte se encontram na situação do devedor no caso concreto.

Daí considerar-se que restará caracterizado um risco de descumprimento em todas aquelas situações em que há alta probabilidade de descumprimento da prestação sob circunstâncias iguais (ou o mais próximo possível) às do caso concreto, ou seja, a configuração do risco de descumprimento se baseia em um juízo da probabilidade do

\footnotetext{
${ }^{498}$ Nesse sentido o seguinte acórdão do Tribunal de Justiça do Rio Grande do Sul: "VENDA DE AÇÕES E CONTROLE ACIOÁRIO DE EMPRESA. PREÇO CONSTITUÍDO POR PARCELA EM DINHEIRO E CONCURSO PARA CONSTRUÇÃO DE GRANDE PRÉDIO DESTINADO À HOTEL DE TURISMO. RECUSA DO VENDEDOR DAS AÇÕES EM EFETUAR A TRANSFERÊNCIA DAS MESMAS, RECEOSO DO NÃO CUMPRIMENTO DA CONTRAPRESTAÇÃO DA COMPRADORA. AÇÃO DE RESCISÃO DO NEGÓCIO. AÇÃO CONCOMITANTE DA ADQUIRENTE, OBJETIVANDO COMPELIR O VENDEDOR A TRANSFERIR AS AÇÕES. EXCEÇÃO DE INSEGURIDADE DO VENDEDOR.INADIMPLEMENTO DA COMPRADORA, QUE APENAS SATISFEZ A PARCELA DO PREÇO REPRESENTADA POR MOEDA CORRENTE. IMPROCEDÊNCIA DA AÇÃO DO VENDEDOR, MAS ACOLHIMENTO DA EXCEÇÃO DE INSEGURIDADE. PROCEDÊNCIA PARCIAL DA AÇÃO DA COMPRADORA, SUJEITA A PRESTAR CAUÇÃO DO CUMPRIMENTO DE SUA CONTRAPRESTAÇÃO. PROVIMENTO PARCIAL À PRIMEIRA APELAÇÃO E INTEGRAL À SEGUNDA." (TJRS, Apelação Cível no 500406772, Rel. Des. Edson Alves de Souza, j. 27.10.1982) ${ }^{499}$ MIRANDA, Pontes de. Tratado de Direito Privado. T. XXVI. Rio de Janeiro: Editor Borsoi. 1959. p. 110.
} 
descumprimento da prestação devida ${ }^{500}$. Assim, se for mais provável do que improvável o descumprimento da prestação devida, há efetivo risco de descumprimento, a autorizar o credor a adotar as medidas cabíveis para a proteção do credito $^{501}$.

A orientação mais abrangente acerca do risco de descumprimento, a contemplar não apenas a deterioração patrimonial, mas também toda e qualquer circunstância que demonstre a probabilidade do devedor não adimplir a prestação devida, está alinhada com o que dispõe a Convention on Contracts for the International Sales of Goods sobre o tema:

Article 71

(1) A party may suspend the performance of his obligations if, after the conclusion of the contract, it becomes apparent that the other party will not perform a substantial part of his obligations as a result of:

(a) a serious deficiency in his ability to perform or in his creditworthiness; or

(b) his conduct in preparing to perform or in performing the contract. ${ }^{502}$

Em comentários sobre o artigo 71 da Convention on Contracts for the International Sales of Goods, Schlechtriem \& Schwenzer afirmam que o referido dispositivo "autoriza o credor a suspender o cumprimento de suas obrigações, se o cumprimento de parcela essencial dos deveres do devedor é incerto" ${ }^{\circledR 03}$, o que dependerá da comprovação de uma deficiência séria na habilidade do devedor cumprir a sua obrigação ou no seu comportamento rumo ao adimplemento ${ }^{504}$.

\footnotetext{
${ }^{500}$ Segundo Cristiano de Sousa Zanetti, "não se exige, todavia, que o descumprimento seja certo. Basta que seja altamente provável, segundo a avaliação de uma pessoa razoável, familiarizada com as práticas do mercado. Não se deve atribuir maior relevância, por outro lado, a meras especulações, fruto de uma sensibilidade excessiva que porventura caracterize uma das partes". ZANETTI, Cristiano de Souza. Inadimplemento Antecipado da Obrigação Contratual. In: CELLI JUNIOR, Umberto; BASSO, Maristela; AMARAL JÚNIOR, Alberto do (Coord). Arbitragem e comércio internacional: estudos em homenagem a Luiz Olavo Baptista. São Paulo: Quartier Latin. 2013. p. 321.

501 TERRA, Aline de Miranda Valverde. Inadimplemento anterior ao termo. Rio de Janeiro: Renovar. 2009. p. 190.

502 Em tradução livre: "Artigo 71
}

(1) A parte pode suspender a execução de sua obrigação caso, após a conclusão do contrato, torna-se aparente que a outra parte não cumprirá parte substancial de suas obrigações em função de:

(a) uma deficiência séria em sua capacidade de cumprir ou em seu merecimento de crédito; ou

(b) sua conduta na preparação para cumprir ou na execução do contrato."

${ }^{503}$ SCHLECHTRIEM, Peter; SCHWENZER, Ingeborg. Comentários à Convenção das Nações Unidas sobre Contratos de Compra e Venda Internacional de Mercadorias. Coordenação de tradução de Eduardo Grebler, Vera Fradera, César Guimarães Pereira. São Paulo: Editora Revista dos Tribunais. 2014. p. 1.058.

504 Jelana Vilus afirma que "as provided by Art. 71, one of the contracting parties may suspend his obligations if, after the conclusion of the contract, it becomes evident that the other party will 'not perform a 
No mesmo sentido se encontra o artigo 7.3.4 dos princípios UNIDROIT relativos aos Contratos Comerciais Internacionais:

\begin{abstract}
Uma parte que acredite razoavelmente que haverá inadimplemento essencial pela outra parte pode exigir garantia adequada do adimplemento e, nesse entretempo, suspender a execução de sua própria obrigação. Se a garantia não é dada dentro de prazo razoável, a parte que a exigiu pode extinguir o contrato.
\end{abstract}

Com relação ao referido artigo, João Baptista Villela assevera que ele protege o interesse da parte que acreditar que a outra parte será incapaz ou não estará disposta a adimplir o contrato no termo pactuado contratualmente, mas não pode valer-se do artigo 7.3.3 dos princípios UNIDROIT relativos aos Contratos Comerciais Internacionais, que trata do inadimplemento antecipado do contrato, "uma vez que ainda há uma possibilidade de que a outra parte ainda queira ou possa adimplir" ${ }^{305}$.

O conceito mais abrangente de risco de descumprimento também encontra abrigo no mais recente projeto europeu da unificação do direito dos contratos: o Draft Common Frame of Reference, cujo art. III - 3:401 também confere à parte inocente o direito de suspender a execução da prestação respectiva, se houver motivo razoável para supor que o pactuado não será observado pelo outro contratante ${ }^{506}$.

substantial part of his obligations'. However, it is not sufficient that this is foreseeable on the basis of a subjective evaluation of one of the parties and may also be the ground for an abuse. Instead, the Vienna Convention insists on two additional conditions: a serious deficiency in his ability to perform or in his creditworthiness; or his conduct in preparing to perform or in performing the contract". VILUS, JELENA. Provisions common to the obligations of the seller and the buyer. In: International Sale of Goods. Dubrovnik Lectures. Oceana Publications. 1986. p. 241) Em tradução livre: "conforme previsto no Artigo 71, uma das partes contratantes poderá suspender as suas obrigações se, após a celebração do contrato, tornar-se evidente que a outra parte 'não vai substancialmente adimplir com as suas obrigações'. No entanto, não é suficiente que seja previsível com base em uma avaliação subjetiva de uma das partes, podendo ser motivo de abuso. Em vez disso, a Convenção de Viena insiste em duas condições adicionais: uma deficiência séria em sua capacidade de cumprir ou em seu merecimento de crédito; ou na sua conduta na preparação para cumprir ou na execução do contrato."

505 VILLELA, João Baptista et al. Princípios UNIDROIT relativos aos Contratos Comerciais Internacionais/2004 [versão em língua portuguesa]. São Paulo: Quartier Latin. 2009. p. 239.

506 "III.3:401: Right to withhold performance of reciprocal obligation

(1) A creditor who is to perform a reciprocal obligation at the time as, or after, the debtor perform has a right to withhold performance of the reciprocal obligation until the debtor has tendered performance or has performed.

(2) A creditor who is to perform a reciprocal obligation before the debtor performs and who reasonably believes that there will be non-performance becomes due may withhold performance of the reciprocal 
Diante do exposto, resta demonstrado que o inadimplemento antecipado se distingue do mero risco de descumprimento por exigir uma probabilidade próxima da certeza de que o devedor não desejará ou conseguirá adimplir a prestação no termo contratual; aplicando-se o risco de descumprimento àquelas situações em que o devedor por seu comportamento ou pela deterioração do seu patrimônio - torna duvidosa, com um alto de grau de probabilidade, a entrega da prestação devida no momento, modo e lugar pactuado entre as partes.

Neste sentido são as lições de Cristiano de Sousa Zanetti:

\begin{abstract}
No Direito brasileiro, a eventual dúvida opera em favor do devedor, uma vez que o regramento do Código Civil lhe assegura a possibilidade de empregar todo o tempo disponível para cumprir sua prestação. Caso sua conduta apenas ponha em risco a satisfação do programa contratual, o credor pode, no máximo, opor a exceção de inseguridade.

Sendo certa a inexecução do pactuado, por outro lado, carece de sentido condicionar a intervenção do contratante prejudicado à expiração do termo acordado. Raciocinar em sentido diverso implicaria punir quem pretende ater-se do avençado, para proteger aquele que se recusa a honrar o prometido. Repudiar a deslealdade é imprescindível à preservação do princípio da boa-fé, cuja centralidade para o direito dos contratos não comporta discussão ${ }^{507}$.
\end{abstract}

obligation for as long as the reasonable belief continues. However, the right to withhold performance is lost if the debtor gives an adequate assurance of due performance.

(3) A creditor who withholds performance in the situation mentioned in paragraph (2) has a duty to give notice of that fact to the debtor as soon as is reasonably practicable and is liable for any loss caused to the debtor by a breach of that duty.

(4) The performance which may be withheld under this Article is the whole part of the performance as may be reasonable in the circumstances."

Em tradução livre: "III.3:401: Direito à recusa da prestação da obrigação recíproca

(1) O credor que deverá cumprir uma obrigação recíproca no momento ou após o cumprimento do devedor terá o direito de reter o cumprimento da obrigação recíproca até que o devedor tenha cumprido com as obrigações assumidas.

(2) O credor que deverá cumprir uma obrigação recíproca antes do devedor cumprir a sua obrigação e que razoavelmente acreditar que haverá inadimplemento, pode se recusar a cumprir a obrigação recíproca enquanto continuar a acreditar no inadimplemento. No entanto, o direito de reter o cumprimento da obrigação se extingue se o devedor prestar garantia do cumprimento.

(3) O credor que retiver sua obrigação na situação descrita no parágrafo (2) tem o dever de notificar o fato ao devedor assim que possível e é responsável por perdas e danos causados ao devedor pelo descumprimento desse dever.

(4) A obrigação que pode ser retida de acordo com esse artigo é toda a parte da obrigação que se demonstrar razoável nas circunstâncias."

507 ZANETTI, Cristiano de Souza. Inadimplemento Antecipado da Obrigação Contratual. In: CELLI JUNIOR, Umberto; BASSO, Maristela; AMARAL JÚNIOR, Alberto do (Coord). Arbitragem e comércio internacional: estudos em homenagem a Luiz Olavo Baptista. São Paulo: Quartier Latin. 2013. p. 324. 
É importante advertir que o perigo que se corre ao analisar o inadimplemento antecipado sem distingui-lo do risco de descumprimento, bem como sem atentar para a possibilidade de ampliação do seu suporte fático objetivo, é qualificar situações em que é duvidosa a entrega da prestação devida como inadimplemento antecipado, que dá ensejo a consequências jurídicas mais severas, conforme se examinará no terceiro capítulo.

\subsection{A funcionalização do termo contratual}

Como exposto no primeiro capítulo, todos os conceitos e institutos do direito obrigacional devem ser relidos sob uma perspectiva finalística e funcional, indagando-se sobre o que justifica a sua existência e tutela jurídica. Neste item será realizada uma análise funcional do termo contratual ${ }^{508}$, que é uma abordagem imprescindível no exame do tema do inadimplemento antecipado do contrato.

A visão da "obrigação como processo" permite compreender o seu caráter finalístico e transitório: a obrigação dirige-se sempre ao adimplemento e à satisfação do interesse do credor $^{509}$. Encaminhada desde a sua constituição para esse fim, a relação obrigacional nasce para se extinguir ${ }^{510}$. O tempo ${ }^{511}$ assume, assim, inegável relevância nas relações obrigacionais.

\footnotetext{
${ }^{508}$ Sobre o conceito de termo: "o termo consiste no elemento que subordina o início ou o término da eficácia do negócio jurídico a um evento futuro e certo (Zeno Veloso, Condição, p. 82). A futuridade e a certeza do evento caracterizam o termo. Desse modo, sua ocorrência só poderá se verificar no futuro. Não se confunde com a condição especificamente pela certeza que o caracteriza, de modo que a existência e a eficácia do negócio com termo estão asseguradas, verificando somente um limite temporal especial". TEPEDINO, Gustavo; BARBOZA, Heloisa Helena; MORAES, Maria Celina Bodin de. Código Civil interpretado conforme a Constituição da República. v. I, 2. ed. rev. e atual. Rio de Janeiro: Renovar. 2007. p. 263. Caio Mário da Silva Pereira afirma que "a eficácia do negócio jurídico pode ser temporalmente determinada, ficando a declaração de vontade subordinada ao curso de tempo. Fixam as partes ou estipula o agente um momento em que começa ou cessa a produção de seus efeitos. A esse dia dá-se o nome de termo, que pode assim ser inicial ou final. É inicial ou suspensivo (dies a quo), quando é a partir dele que se pode exercer o direito; é final ou extintivo (dies ad quem), quando nele encontra fim a produção de efeitos do negócio jurídico". PEREIRA, Caio Mário da Silva. Instituições de direito civil. v. I. 21. ed. Rio de Janeiro: Forense. 2005. p.575.

${ }^{509}$ SILVA, Clóvis do Couto e. A obrigação como processo. Rio de Janeiro: Editora FGV. 2006. p. 168.

510 SILVA, João Calvão da. Cumprimento e sanção pecuniária compulsória. Coimbra: Livraria dos Advogados Editora. 1987. p. 72.

511 Para uma análise aprofundada sobre o tema do "tempo", recomenda-se: SIMÃO, José Fernando. Prescrição e decadência: início dos prazos. São Paulo: Atlas. 2013.
} 
O interesse humano pode ser colocado no tempo, sob o ponto de vista jurídico, de diversos modos. Nos negócios instantâneos, a constituição e a extinção da relação obrigacional coincidem. Todavia, na maioria das vezes, há um lapso temporal entre o início e a extinção da relação, quando as partes ajustam um prazo para o adimplemento da prestação. Nesse caso, a relação obrigacional se apresenta como um conjunto de atos dirigidos à realização do interesse do credor no termo ajustado ${ }^{512}$.

Saliente-se que o termo contratual representa o lapso temporal necessário para que o devedor possa cumprir a prestação devida, realizando todos os atos preparatórios e de execução necessários para tanto. Ademais, o termo também expressa relação entre o tempo e interesse do credor, já que, em geral, especifica o momento temporal em que o seu interesse deve ser satisfeito com a realização da prestação devida ${ }^{513}$.

Com o termo, subordina-se a realização do interesse do credor à verificação de evento futuro e certo, de modo a limitar temporalmente a exigibilidade da prestação. Portanto, o termo limita a eficácia da obrigação ${ }^{514}$ : quando houver termo pactuado entre as

512 O tempo pode ser fator de classificação das obrigações, a partir do que se distinguem efeitos e regramentos jurídicos próprios. Duas são elas: as obrigações puras e as obrigações a termo (com prazo para pagamento). As obrigações puras são aquelas nas quais não há prazo para o pagamento, devendo a obrigação ser prestada imediatamente; ao passo que a obrigação a termo (ou a prazo) é definida pela doutrina como "aquela em que as partes subordinam os efeitos do negócio jurídico a um evento futuro e certo". GONÇALVES, Carlos Roberto. Direito civil brasileiro. v. 2: Teoria geral das obrigações. 8. ed. São Paulo: Saraiva. 2011. p. 204.

${ }^{513}$ A determinação do momento em que a obrigação deve ser cumprida é de fundamental importância, haja vista que a obrigação somente se torna exigível quando vencida. Em regra, o vencimento de uma obrigação é estipulado pelos contratantes, derivando de sua vontade, mas nem sempre isso acontece (há relações obrigacionais sem essa estipulação, outras existem em que o vencimento decorre da natureza da prestação, e a própria lei o determina em alguns casos). Quando o vencimento não é voluntariamente estipulado, ou não decorre da natureza da prestação ou de lei, o credor pode exigir o cumprimento imediato da obrigação (princípio da satisfação imediata). Quando houver data para vencimento da obrigação a sua aposição difere o direito do credor de exigir a prestação. A esse respeito, Cristiano de Sousa Zanetti comenta que "na falta de estipulação a propósito do tema, o credor pode exigir o adimplemento desde logo, segundo previsto no art. 331 do Código Civil. Frequentemente, porém, as partes preferem disciplinar a relação de modo diverso, com o propósito de interpor certo lapso temporal entre a celebração e a execução do contrato. Para tanto, concluem um contrato de execução diferida, continuada ou periódica. Nas duas últimas hipóteses, a dilação temporal desempenha um papel decisivo na economia contratual, razão pela qual tais negócios costumam ser qualificados como contratos de duração". ZANETTI, Cristiano de Souza. Inadimplemento Antecipado da Obrigação Contratual. In: CELLI JUNIOR, Umberto; BASSO, Maristela; AMARAL JÚNIOR, Alberto do (Coord). Arbitragem e Comércio Internacional: estudos em homenagem a Luiz Olavo Baptista. São Paulo: Quartier Latin. 2013. p. 312.

${ }^{514}$ Sobre a questão, confira-se o posicionamento de Jorge Cesa Ferreira da Silva: "quando o pagamento é protraído, o prazo entre o nascimento da obrigação e do vencimento corresponde, na prática, aos interesses de uma ou de ambas as partes. O prazo pode ter sido dado porque o credor não podia receber as máquinas 
partes "a sua aposição difere o direito do credor de exigir a prestação" 515 . Nessa direção, diz-se que, na obrigação a termo, a situação jurídica, apesar de existente, afigura-se inexigível (inexigibilidade provisória).

Entretanto, conforme será exposto a seguir, o termo, por si só, não importa necessariamente a inexigibilidade da prestação. Isso porque apenas uma análise funcional do termo - conduzida à luz da concepção dinâmica e funcional da obrigação - pode indicar se aquela estrutura é capaz de produzir determinado resultado e deverá ser mantida no caso concreto. Para tanto, deverá ser examinado o fundamento da inexigibilidade da obrigação, o interesse que o termo visa tutelar concretamente no âmbito daquela particular relação jurídica $^{516}$.

A princípio, interpreta-se o termo contratual em favor do devedor, salvo se constar de maneira diversa no contrato ou se das circunstâncias resultar que o termo foi estabelecido em benefício do credor (artigo 133 do Código Civil) ${ }^{517}$. A presunção de que o termo contratual deve ser interpretado em favor do devedor visa favorecer a execução do débito e conferir prazo para o devedor cumprir a sua obrigação. Desse modo, tem-se que,

adquiridas antes de ter o seu pessoal treinado para usá-las, ou porque o devedor não tinha dinheiro para realizar o pagamento à vista, ou ainda porque as duas partes estavam distantes do lugar em que a prestação deveria se realizar, necessariamente com a participação de ambas. Assim, o prazo pode ser fixado em 'benefício' do credor, do devedor ou no benefício de ambas as partes (o chamado 'termo netutro'). (SILVA, Jorge Cesa Ferreira da. Adimplemento e Extinção das Obrigações. São Paulo: Editora Revista dos Tribunais. 2007. p. 253).

${ }^{515}$ GOMES, Orlando. Obrigações. 16. ed. rev., atual. e aum., de acordo com o Código Civil de 2002, por Edvaldo Brito. Rio de Janeiro: Forense. 2005. p. 119.

516 TERRA, Aline de Miranda Valverde. Inadimplemento anterior ao termo. Rio de Janeiro: Renovar. 2009. p. 71.

${ }^{517}$ Cristiano de Sousa Zanetti afirma que "de acordo com o art. 133 do Código Civil, presume-se que o termo tenha sido estabelecido em favor do devedor. Por outras palavras, embora a prestação ainda não seja exigível, o devedor pode dela se desincumbir, dado que o cumprimento só tende a favorecer o próprio destinatário. Não há espaço, porém, para que o credor reclame sua execução antes do tempo. Prevê-se, inclusive, pena para quem procede de maneira açodada, conforme disposto no art. 939, também do Código Civil. Nada obsta, entretanto, que o termo seja estabelecido em favor de ambas as partes, caso em que nenhuma delas poderá deixar de observá-lo, exceção feita ao previsto no art. 52, $\S 2^{\circ}$, do Código de Defesa do Consumidor. Somente muito raramente o termo será estabelecido em favor do credor, situação em que não poderá ser foçado a aceitar a prestação antes da hora". ZANETTI, Cristiano de Souza. Inadimplemento Antecipado da Obrigação Contratual. In: CELLI JUNIOR, Umberto; BASSO, Maristela; AMARAL JÚNIOR, Alberto do (Coord). Arbitragem e comércio internacional: estudos em homenagem a Luiz Olavo Baptista. São Paulo: Quartier Latin. 2013. p. 313. 
de regra, o termo implica a inexigibilidade da prestação e limita o exercício do direito de crédito $^{518}$.

Entende-se que, enquanto benefício, o termo pode ser renunciado por seu beneficiário. Assim, o termo estabelecido em benefício do devedor permite que este adimpla a sua obrigação antes do seu advento, negando-se ao credor o direito de recusar o recebimento da prestação, sob pena de incorrer em mora (mora creditoris). De outro lado, o credor não pode exigir o adimplemento antecipadamente ao termo fixado em benefício do devedor, salvo nas exceções previstas em lei ${ }^{519}$.

O termo também pode ser fixado em benefício do credor, hipótese em que não se suspende a exigibilidade, mas a possibilidade de cumprimento. Isso significa dizer que o credor pode exigir o cumprimento da obrigação desde logo, mas o devedor não pode prestar antes de transcorrido o prazo. A obrigação é exigível nesse caso. É o que ocorre no exemplo clássico do contrato de depósito, no qual, nada obstante a existência de prazo, pode o credor da coisa (depositante) exigi-la a qualquer momento ${ }^{520}$.

Na hipótese de o termo contratual ter sido ajustado em benefício de ambos os contratantes, a prestação é inexigível e inexequível até a verificação do termo. Assim, nenhuma das partes pode renunciar ao termo sem o consentimento prévio da outra, de maneira que o credor não pode exigir o cumprimento da obrigação antes do termo e o devedor não pode adimplir antes de seu advento. Exemplo é o contrato de mútuo feneratício, cuja fluência de juros compensatórios faria presumir que o prazo contratual é resultado do interesse de ambas as partes ${ }^{521}$.

\footnotetext{
518 AZEVEDO, Álvaro Villaça. Teoria geral das obrigações. 6. ed., São Paulo: Editora Revista dos Tribunais. 1997. p. 128.

${ }^{519}$ SILVA, Jorge Cesa Ferreira da. Adimplemento e extinção das obrigações. São Paulo: Editora Revista dos Tribunais. 2007. p. 253.

${ }^{520} \mathrm{O}$ exemplo é de SILVA, Jorge Cesa Ferreira da. Adimplemento e extinção das obrigações. São Paulo: Editora Revista dos Tribunais. 2007. p. 255.

${ }^{521}$ O exemplo é de SILVA, Jorge Cesa Ferreira da. Adimplemento e extinção das obrigações. São Paulo: Editora Revista dos Tribunais. 2007. p 256.
} 
Verifica-se, assim, que, em regra, o termo ajustado em benefício do devedor ou de ambas as partes importa em inexigibilidade da prestação durante a sua pendência (inexigibilidade temporária). Entretanto, um exame funcional do termo contratual, à luz das especificidades do caso concreto, pode excepcionar a regra, tornando a prestação exigível antes de seu advento.

Como dito acima, presume-se ajustado o termo em benefício do devedor a fim de conferir-lhe o tempo suficiente e necessário para o adimplemento da prestação, de maneira a protegê-lo de qualquer exigência antecipada da prestação. A rigor, o credor apenas confere o benefício do tempo ao devedor porque confia nele, ou seja, porque o devedor aparenta ter vontade e aptidão para adimplir, bem como porque ele, ao concordar com o prazo, demonstra séria intenção de observá-lo. A concessão de prazo para adimplir pressupõe, assim, confiança no cumprimento da prestação pelo devedor ${ }^{522}$.

Conforme aponta João Calvão da Silva, a própria celebração do contrato pressupõe a confiança do credor no devedor, "na sua vontade e capacidade de cumprir a prestação a que se vincula. $O$ credor acredita no normal desenvolvimento da relação, segundo a vontade das partes e a função econômica tida em vista no momento inicial, a culminar no cumprimento"

Assim sendo, dúvidas fundadas quanto à possibilidade ou à intenção do devedor prestar no termo pactuado impedem a manutenção do benefício do termo porque deixa de justificar-se a confiança do credor no devedor, que está na base da concessão do prazo $^{524}$. Diante de tais incertezas, Carvalho Santos afirma que o devedor "não pode mais

\footnotetext{
522 TERRA, Aline de Miranda Valverde. Inadimplemento anterior ao termo. Rio de Janeiro: Renovar. 2009. p. 76.

523 SILVA, João Calvão da. Cumprimento e Sanção Pecuniária Compulsória. Coimbra: Livraria dos Advogados Editora. 1987. p. 69.

${ }^{524}$ É assim que se posiciona Antunes Varela: "Há circunstâncias que, apesar de a obrigação ser a prazo e de este ser estabelecido em benefício exclusivo ou conjunto do devedor, determinam o vencimento imediato da obrigação, por caducidade do prazo estabelecido. A primeira delas, prevista no n. ${ }^{\circ}$ I do artigo $780^{\circ}$, é a de 'o devedor se tornar insolvente, ainda que a insolvência não tenha sido judicialmente declarada'. A insolvência consiste na situação em que se encontra o devedor, cujo passivo excede o activo do seu patrimônio. Logo que esta situação se verifique, a dívida a termo torna-se imediatamente exigível, na medida em que deixa de justificar-se a confiança do credor no devedor, que está na base da concessão do prazo." VARELA, João de Mattos Antunes. Das obrigações em geral. Coimbra: Almedina. 1970. p. 722.
} 
merecer essa confiança, não pode subsistir o prazo, pressupondo-se subentendido que o devedor, ao contratar, houvesse feito essa ressalva natural" ${ }^{, 525}$.

Em caso de perda superveniente da confiança que o credor depositou no devedor, o ordenamento jurídico deverá garantir ao credor meios mais vigorosos para a proteção dos seus direitos e interesses, conforme observam Luis Diez-Picazo e Antonio Gullon:

Existen casos en los cuales, no obstante haberse establecido un plazo para el cumplimiento, la ley permite que el acreedor dé anticipadamente por vencida la deuda y, según la expresión legal, que el deudor pierda el derecho a utilizar el plazo. Se trata de casos en que se produce una sobrevenida perdida de la confianza en el deudor y en que es necesario otorgar al acreedor una protección más vigorosa. ${ }^{526}$

Confira-se o posicionamento de Orlando Gomes sobre a questão da perda da confiança de que o devedor cumprirá a prestação, que autoriza que a obrigação seja considerada antecipadamente vencida nos casos previstos em lei:

[...] No exame da matéria relativa ao tempo de pagamento, interessa o dia do vencimento da obrigação. A sua aposição difere o direito do credor de exigir a prestação. Antes do seu advento, a pretensão do direito de crédito fica em suspenso, mas, como o termo é ordinariamente estipulado em favor do devedor, assegura-se-lhe a faculdade de pagar antecipadamente. O credor não pode, entretanto, cobrar a dívida antes de vencido o prazo estipulado no contrato. Dizse que espera porque tem confiança em que o devedor cumprirá a prestação, tanto que, se houver fundado motivo para desconfiança, a lei autoriza a cobrança antecipada. É possível em três hipóteses:

$1^{\mathrm{a}}$ - Se, executado o devedor, ou no caso de falência do devedor;

$2^{\mathrm{a}}$ - se os bens hipotecados, empenhados ou dados em anticrese, forem penhorados em execução por outro credor;

$3^{\mathrm{a}}$ - se cessarem ou se tornarem insuficientes as garantias do débito, e o devedor, intimado, se negar a reforçá-las. ${ }^{527}$

${ }^{525}$ CARVAlho SANTOS, J. M. de. Código Civil brasileiro interpretado. v. XII. 8. Ed, Rio de Janeiro: Livraria Freita Bastos. 1963, p. 299.

${ }^{526}$ DIEZ-PICAZO, Luis e GULLON, Antonio. Sistema de depreco civil. v. II. Editorial Tecnos: Madrid. 1978. p. 127. Em tradução livre: "existem casos em que, apesar de haver sido estabelecido um prazo para o cumprimento, a lei permite que o credor repute a dívida antecipadamente vencida e, segundo a expressão utilizada na lei, o devedor perca o direito de utilizar o prazo. Trata-se dos casos em que há uma perda superveniente da confiança no devedor e em que é necessário outorgar ao credor uma proteção mais vigorosa."

${ }^{527}$ GOMES, Orlando. Obrigações. 16. ed. rev., atual. e aum., de acordo com o Código Civil de 2002, por Edvaldo Brito. Rio de Janeiro: Forense. 2005. p. 120-121. 
Com efeito, o Código Civil, no artigo 333, confere ao credor o direito de cobrar a dívida antes do vencimento do prazo no caso de falência do devedor ou concurso de credores (inciso I), de penhora em execução por outro credor dos bens hipotecados ou empenhados (inciso II), ou no caso de cessarem ou se tornarem insuficientes as garantias do débito, fidejussórias ou reais, e o devedor, intimado, negar-se a reforçá-las. Trata-se de hipóteses de modificação objetiva da situação patrimonial do devedor ou das garantias que levaram o credor a celebrar o contrato.

A doutrina geralmente afirma que somente nas hipóteses legalmente previstas de vencimento antecipado a obrigação se torna exigível antes do termo contratual $^{528}$. Todavia, a nosso ver, a leitura funcionalizada do termo contratual leva à conclusão de que o direito ao benefício do termo que não realiza a função para a qual foi concebido não merece tutela do ordenamento jurídico, pelo que deve ser desconsiderado, e a prestação passa a ser imediatamente exigível.

Entendemos que a concepção tradicional do termo deve ser abandonada à luz da análise dinâmica e funcional do direito das obrigações, segundo a qual o termo deverá, a todo tempo, exercer a função para a qual ele foi concebido naquela relação obrigacional para continuar a merecer tutela no ordenamento jurídico e beneficiar o devedor. Não há um direito subjetivo do devedor ao termo contratual, mas um "benefício" conferido pelo ordenamento jurídico enquanto o termo desempenhar uma função na relação contratual.

A função do termo reside em conferir prazo ao devedor para que possa adimplir perfeitamente a sua obrigação e satisfazer o interesse do credor. Aí reside a sua razão justificadora. Como esta função do termo deve se manter ao longo de toda a relação obrigacional, deve-se avaliar durante o seu decurso se o devedor está exercitando seu direito ao benefício do termo. Somente neste caso o direito ao benefício do termo merece tutela no ordenamento jurídico.

${ }^{528}$ GOMES, Orlando. Obrigações. 16. ed. rev., atual. e aum., de acordo com o Código Civil de 2002, por Edvaldo Brito. Rio de Janeiro: Forense. 2005. p. 121. 
Desta feita, se por qualquer razão restar demonstrado que o exercício do benefício do termo não serve mais para permitir que o devedor cumpra a sua obrigação, porque o devedor manifestamente não quer adimplir, ou porque a obrigação se tornou impossível ou inútil para o credor, por fato imputável ao devedor, impõe-se a perda do benefício, e a prestação se torna, desde logo, exigível.

Acrescente-se que a perda do benefício do termo em caso de desaparecimento da confiança de que o devedor irá adimplir no prazo pactuado se justifica na boa-fé objetiva. É nitidamente contrário à boa-fé manter o benefício do termo para um devedor que não o utiliza para adimplir a sua obrigação ${ }^{529}$. Essa situação caracteriza uma hipótese de supressio, que "pode ser definida como a impossibilidade de exercício de uma posição jurídica em razão de sua não utilização por um período de tempo" ${ }^{, 530}$, impondo a perda do benefício do termo contratual.

Frise-se que na situação discutida acima não se trata de vencimento antecipado da dívida - como as situações reguladas pelo artigo 333 do Código Civil -, que só têm lugar nas hipóteses legalmente previstas. Trata-se da não realização da função do termo, que acarreta a consequência de que o direito ao benefício do termo não seja mais digno de tutela e justifica a sua perda pelo devedor. Por essa razão, afirma-se que a obrigação a termo é, normalmente, inexigível, mas a manutenção da inexigibilidade depende da capacidade do termo realizar a sua função ${ }^{531}$.

\subsection{Natureza jurídica do inadimplemento antecipado}

O desenvolvimento da teoria do inadimplemento antecipado do contrato no direito brasileiro revela algumas posições doutrinárias antagônicas no que diz respeito à

\footnotetext{
${ }^{529}$ A esse respeito, Cristiano Chaves de Farias e Nelson Rosenvald afirmam que "a recusa antecipada ao cumprimento da obrigação é também uma forma de violação ao princípio da boa-fé, pois a conduta que denota a falta de interesse de uma das partes em cumprir o dever de prestar é certamente uma lesão ao dever de confiança que inspira qualquer relação negocial”. FARIAS, Cristiano Chaves de; ROSENVALD, Nelson. Curso de direito civil 1. 11.. ed, Salvador: Editora JusPodivm. 2013. p. 728.

${ }^{530}$ SIMÃO, José Fernando. Prescrição e decadência: início dos prazos. São Paulo: Atlas. 2013. p. 194.

531 TERRA, Aline de Miranda Valverde. Inadimplemento anterior ao termo. Rio de Janeiro: Renovar. 2009. p. 81.
} 
sua natureza jurídica. Os primeiros estudos sobre a figura do inadimplemento antecipado apontavam-no como uma hipótese de vencimento antecipado da dívida. É este o entendimento defendido por Serpa Lopes, segundo o qual estaria configurada hipótese de vencimento antecipado da obrigação na hipótese de suspeição de inadimplemento ou quando uma parte exige da outra o seu crédito após ter declarado peremptoriamente o seu propósito de não adimplir a prestação futura que lhe incumbe.

Confira-se o seguinte trecho da obra de Serpa Lopes ilustrativo da posição do autor:

[...] não se trata de cobrir a lei, de riscar o seu texto ou escrever por ele, e sim de um princípio que se pode lançar nos livres espaços da lei Acrescenta-se, assim, aos casos de vencimento antecipado em razão de um estado falencial ou de uma situação de desconfiança resultante de certos atos praticados pelo devedor, uma outra hipótese em que o vencimento antecipado não é alarmante, não se espraia por toda a situação financeira do devedor, apenas se restringe a uma situação singular, para a qual manifestou o propósito de se tornar inadimplente.

$\mathrm{Na}$ verdade, o princípio geral é o de o termo haver sido instituído em benefício do devedor e que a sua pactuação importa em retirar ao credor a possibilidade de exigir o adimplemento da prestação antes do seu vencimento. Nem é outro o sentido do art. 126 do Código Civil, prescrevendo que, nos contratos, o prazo se presume em proveito do devedor, do que resulta que só ao próprio devedor, quando do seu interesse, é que cabe, de regra, adimplir antecipadamente a sua prestação, mesmo contra a vontade do credor, a menos que se haja convencionado o prazo em favor do próprio credor.

E a razão desse princípio é lógica: o vencimento antecipado produz o inquestionável enriquecimento em benefício do credor, e assim, só ao próprio devedor ou em casos em que a lei o determina, pode a prestação ser exigida antecipadamente. Mas, indubitavelmente, tanto na situação de suspeição como no caso de afirmação antecipada do propósito de não adimplir, tudo isso representa uma circunstância que exige deferir-se ao credor uma posição protetora, máxime ao momento em que ele, a seu turno, como credor é obrigado a cumprir uma prestação organicamente vinculada a uma outra ainda futura de que é credor, porém já tendo ela impendente a afirmação categórica de não ir ser cumprida. $^{532}$

Outros autores identificam o inadimplemento antecipado como uma situação de pré-inadimplência, a qual reuniria todas as circunstâncias nas quais fica comprovada a alta probabilidade de incumprimento da prestação. São favoráveis a este entendimento

532 SERPA LOPES, Miguel Maria. Exceções substanciais: exceção de contrato não cumprido (exceptio non adimpleti contractus). Rio de Janeiro: Freitas Bastos. 1959. p. 293-295. 
João Baptista Villela ${ }^{533}$ e Fortunato Azulay $^{534}$. De acordo com Fortunato Azulay, a situação de pré-inadimplência reuniria todos "aqueles estados de ordem subjetiva ou objetiva, absolutos ou relativos em que se acha o contraente que, por resultarem de fatos presumidos e/ou inequívocos, levam o outro contraente a um justo receio da inexecução da prestação" ${ }^{, 535}$.

Sob a designação de situação de pré-inadimplência o autor abrange todas as circunstâncias em que o devedor "manifesta, unilateralmente, por antecipação ao termo de execução, a sua intenção de não cumprir, ou revela por fatos, atos ou palavras inequívocas e insofismáveis que se tornou impossível (em sentido técnico-jurídico), ou duvidoso, o cumprimento da prestação" ${ }^{\text {536 }}$. Por fim, o autor conclui que as hipóteses fáticas abrangidas pela denominação de situação de pré-inadimplência constituiriam "inexecução in potentia" fortes o bastante para determinar a resolução do contrato ou a sua rescisão, a depender do caso concreto $^{537}$.

Fortunato Azulay analisa duas hipóteses típicas de situação de préinadimplência, quais sejam, "quando o devedor manifesta expressamente a vontade de não querer cumprir" e "quando pratica um ato que impede ou torna impossível o cumprimento ao chegar o termo fixado para o mesmo" ${ }^{538}$. Com relação à segunda hipótese, ao qual dedica maior atenção, ele afirma que o caso mais típico é a mudança do estado econômico do devedor, capaz de comprometer radicalmente a possibilidade do cumprimento da

\footnotetext{
${ }^{533}$ VILLELA, João Baptista. Sanção por inadimplemento contratual antecipado: subsídios para uma teoria intersistemática das obrigações. Belo Horizonte. [s.n]. 1966. p. 11 et seq.

${ }^{534}$ De acordo com Fortunato Azulay, "a esse teor, e do que nos capítulos anteriores ficou explicitado, se poderá afirmar que basta admitir a noção de pré-inexecução ou pré-inadimplência (anticipatory breach) como categoria jurídica da inexecução contratual, para que se possa sistematizar a matéria em face do direito escrito (oriundo do direito continental do chamado grupo romano-germânico) e da doutrina já existente na common law". AZULAY, Fortunato. Do inadimplemento antecipado do contrato. Rio de Janeiro: Editora Brasília/Rio. 1977. p. 112.

${ }_{535}$ AZULAY, Fortunato. Do inadimplemento antecipado do contrato. Rio de Janeiro: Editora Brasília/Rio. 1977. p. 47.

${ }^{536}$ AZULAY, Fortunato. Do inadimplemento antecipado do contrato. Rio de Janeiro: Editora Brasília/Rio. 1977. p. 74.

${ }^{537}$ AZULAY, Fortunato. Do inadimplemento antecipado do contrato. Rio de Janeiro: Editora Brasília/Rio. 1977. p. 53.

${ }^{538}$ AZULAY, Fortunato. Do inadimplemento antecipado do contrato. Rio de Janeiro: Editora Brasília/Rio. 1977. p. 113.
} 
prestação $^{539}$. Ao final da sua análise sobre a segunda hipótese de pré-inadimplência, ele conclui que "já não se tem como objetar à doutrina do vencimento antecipado da obrigação a justificar para a outra parte o direito de ingressar com a ação competente para exigir a mantença do contrato com a consequente exigibilidade da prestação ou a sua rescisão com perdas e danos",540.

Como se observa, as correntes doutrinárias que entendem que a natureza jurídica do inadimplemento antecipado é de vencimento antecipado ou de situação de préinadimplência são fungíveis e se confundem no mais das vezes, uma vez que o pressuposto para a caracterização do vencimento antecipado se funda justamente no fato de o devedor encontrar-se em situação de pré-inadimplência. No entanto, a doutrina mais recente critica a utilização da figura do vencimento antecipado para explicar o inadimplemento antecipado $^{541}$.

A primeira crítica feita ao enquadramento do inadimplemento antecipado como vencimento antecipado é que o rol de hipóteses de inadimplemento antecipado previstas no artigo 333 do Código Civil ${ }^{542}$ é taxativo e não admite a inclusão de outras hipóteses pelo aplicador do direito. Nesse sentido se posicionam Gustavo Tepedino e Anderson Schreiber: “por lei, apenas as hipóteses do art. 333 autorizam a cobrança antecipada da dívida. Nada

${ }^{539}$ AZULAY, Fortunato. Do inadimplemento antecipado do contrato. Rio de Janeiro: Editora Brasília/Rio. 1977. p. 113.

540 AZULAY, Fortunato. Do inadimplemento antecipado do contrato. Rio de Janeiro: Editora Brasília/Rio. 1977. p. 114-115.

${ }^{541}$ Assim entende Jorge Cesa Ferreira da Silva: "De qualquer sorte, os dispositivos citados dão conta da necessidade de distinção, no direito brasileiro, entre o chamado 'inadimplemento antecipado', decorrente da manifestação cabal e limitada quanto aos seus efeitos enquanto inadimplemento, e o 'vencimento antecipado', encontrável em disposições como a do art.954, quando todos os efeitos do inadimplemento poderão verificar-se." SILVA, Jorge Cesa Ferreira da. A boa-fé e a violação positiva do contrato. Rio de Janeiro: Renovar. 2002. p. 262.

542 “Art. 333. Ao credor assistirá o direito de cobrar a dívida antes de vencido o prazo estipulado no contrato ou marcado neste Código:

I - no caso de falência do devedor, ou de concurso de credores;

II - se os bens, hipotecados ou empenhados, forem penhorados em execução por outro credor;

III - se cessarem, ou se se tornarem insuficientes, as garantias do débito, fidejussórias, ou reais, e o devedor, intimado, se negar a reforçá-las.

Parágrafo único. Nos casos deste artigo, se houver, no débito, solidariedade passiva, não se reputará vencido quanto aos outros devedores solventes." 
impede, contudo, que as partes estipulem por convenção outros fatores que produzam o vencimento antecipado" ${ }^{, 543}$.

A segunda crítica é que as hipóteses previstas no artigo 333 do Código Civil não configuram inadimplemento da prestação devida. Com efeito, o legislador elaborou o referido dispositivo a fim de tutelar o direito do credor quando, em razão da falência do devedor, do concurso de credores ou da insuficiência das garantias prestadas, houvesse significativa diminuição de possibilidade de recebimento da prestação. Todas as hipóteses de vencimento antecipada previstas nesse artigo se referem, grosso modo, ao fato de haver evidente enfraquecimento da garantia do débito ${ }^{544}$ (seja em sentido amplo - como o patrimônio do devedor - ou em sentido estrito - no caso do devedor constituir garantias reais ou pessoais vinculadas a um débito específico). O legislador entendeu por bem criar um mecanismo que permitisse ao credor exigir imediatamente o seu crédito quando as garantias do seu crédito se mostrassem insuficientes para sustentar a dívida. Essa é a razão de ser do vencimento antecipado.

O inadimplemento antecipado, por sua vez, não é caracterizado por um enfraquecimento nas garantias do cumprimento do crédito, mas sim na manifestação do devedor no sentido de que não irá cumprir ou na verificação de que, em razão do comportamento do devedor, a prestação será impossível ou inútil quando do advento do termo. Por essas razões, entendemos que não está correta a corrente doutrinária que encontra no vencimento antecipado a natureza jurídica do inadimplemento antecipado.

Nesse sentido se posiciona também Marcos Jorge Catalan:

É importante distinguir quebra antecipada do contrato com vencimento antecipado da obrigação. A última se caracteriza na medida em que a obrigação

\footnotetext{
${ }^{543}$ TEPEDINO, Gustavo; SCHREIBER, Anderson. In: AZEVEDO, Álvaro Villaça (Coord.). Código Civil comentado: direito das obrigações. São Paulo: Atlas. 2008. p. 246.

${ }^{544}$ A esse respeito, Silvio Rodrigues afirma que "em todas as hipóteses de antecipação do vencimento, mencionadas no art. 333 do Código Civil, encontra-se uma constante. Com efeito, os fatos que conferem ao credor o direito de cobrar imediatamente um crédito vincendo são de molde a diminuir a possibilidade de recebimento, se se fosse aguardar até o termo final”. RODRIGUES, Silvio. Direito Civil. v. 2. 30. ed. atual. São Paulo: Saraiva. 2002. p. 162.
} 
ganhe eficácia antes do termo assinalado pelas partes quando da ocorrência de algumas situações no plano concreto.

A figura que interessa ao presente trabalho é distinta, destacando que Ruy Rosado de Aguiar que seria possível o incumprimento antecipado quando se verifique que o devedor adote conduta nitidamente contrária à obrigação assumida ou manifeste-se expressamente no sentido de não cumprir a obrigação, de tal modo que seja possível prever, à luz da base fática objetivamente considerada, que a prestação não será desempenhada. ${ }^{545}$

A doutrina brasileira majoritária ${ }^{546}$, baseando-se nos estudos de Herman $\mathrm{Staub}^{547}$, tem afirmado que o inadimplemento antecipado é uma das hipóteses de violação positiva do contrato. Nesse sentido, Ruy Rosado de Aguiar Júnior afirma que no inadimplemento antecipado "não se pode vislumbrar propriamente uma quebra da obrigação principal, porquanto ainda não se ofereceu o momento oportuno para a exigibilidade da prestação", que o seu fundamento teórico seria a "quebra da confiança quanto ao futuro cumprimento da obrigação" e o classifica como espécie do gênero violação positiva do contrato ${ }^{548}$.

Com efeito, a doutrina majoritária entende que seria impossível caracterizar a quebra antecipada do contrato como inadimplemento absoluto ou mora em razão da ausência do advento do termo. Nessa visão, somente se poderia vislumbrar o inadimplemento antecipado como descumprimento dos deveres instrumentais decorrentes da boa-fé objetiva, in verbis:

No incumprimento antecipado, não se pode propriamente vislumbrar uma quebra da obrigação principal, porquanto ainda não se ofereceu o momento oportuno para a exigibilidade da prestação, mas existe aí situação que, desde logo, evidencia a impossibilidade da prestação sem nada mais ter-se que esperar. Ao menos, há quebra da confiança quanto ao futuro cumprimento, não havendo

\footnotetext{
545 CATALAN, Marcos Jorge. Descumprimento contratual. Curitiba: Juruá, 2005. p. 178. Essa também é a posição de Cristiano Chaves de Farias e Nelson Rosenvald: "a resolução antecipada não é expressa em nossa legislação, não podendo ser confundida com o tradicional instituto do vencimento antecipado do débito. Este é restrito a situações que induzam o devedor à insolvência, conforme se extrai do art. 333 do Código Civil. Já o inadimplemento antecipado verifica-se mesmo quando o devedor ainda for solvente, mas exteriorizar objetivamente a sua vontade de descumprir a obrigação." FARIAS, Cristiano Chaves de; ROSENVALD, Nelson. Curso de direito civil 1. 11. ed, Salvador: Editora JusPodivm. 2013. p. 729.

${ }^{546}$ Neste sentido: FARIAS, Cristiano Chaves de; ROSENVALD, Nelson. Curso de direito civil 1. 11. ed, Salvador: Editora JusPodivm. 2013. p. 729; SILVA, Jorge Cesa Ferreira da. A boa-fé e a violação positiva do contrato. Rio de Janeiro: Renovar. 2002. p 221-223.

${ }^{547}$ Como mencionado no capítulo anterior, Herman Staub classificou o inadimplemento antecipado como uma das hipóteses de violação positiva do contrato.

${ }^{548}$ AGUIAR JR., Ruy Rosado. Extinção dos contratos por incumprimento do devedor (resolução). Rio de Janeiro: Aide, 1991.p. 128.
} 
nenhum interesse social na manutenção de um vínculo que, por tais razões, encontra-se gravemente ferido. ${ }^{549}$

Raphael Manhães Martins, que também parte da premissa de que a quebra antecipada do contrato não poderia caracterizar inadimplemento absoluto ou mora pelo fato da obrigação ainda não ser exigível, sustenta que a justificativa do inadimplemento antecipado do contrato é a violação dos princípios da boa-fé objetiva e proteção da confiança, como se verifica do seguinte trecho:

E, através dessa compreensão, fica evidente a função do inadimplemento antecipado como uma maneira de concretizar os princípios da boa-fé e da confiança. Afinal, nas situações em que algumas das hipóteses fáticas do inadimplemento antecipado ocorrem, como não seria possível invocar nem a mora, nem o inadimplemento absoluto, fica patente que o não reconhecimento do instituto gerará uma situação de violação jurídico material naquele caso concreto. Assim, diante da evidência do caráter instrumental do inadimplemento antecipado para garantir a concretização dos referidos princípios da proteção da confiança legitima e da boa-fé, é inequívoco que o instituto possui guarida em nosso ordenamento civilístico. ${ }^{550}$

A jurisprudência também tem identificado, na violação positiva do contrato, o fundamento para a aplicação da figura do inadimplemento antecipado, in verbis:

Dúvida não resta do inadimplemento da promitente vendedora, desde data anterior à do ajuizamento desta ação de resolução do contrato.

Isso porque, decorrida expressiva parte do prazo de entrega das unidades autônomas, as obras nem sequer tinham ainda iniciado. A conduta da ré configura o que a melhor doutrina denomina violação positiva do contrato, com a quebra antecipada do adimplemento. ${ }^{551}$

Há, ainda, uma variação eclética dessa corrente, sustentada por Jorge Cesa Ferreira da Silva. Para esse autor, o inadimplemento antecipado poderia se revestir ora como violação positiva do contrato, ora como inadimplemento absoluto ou mora. Ele entende que, quando houver afronta antecipada a deveres relacionados diretamente à prestação, o inadimplemento antecipado revestirá a forma de inadimplemento absoluto ou mora. Todavia, será hipótese de violação positiva do contrato o inadimplemento que

\footnotetext{
${ }^{549}$ SAVI, Sérgio. Inadimplemento das Obrigações, Mora e Perdas e Danos. In: TEPEDINO, Gustavo (Coord.). Obrigações: estudos na perspectiva civil-constitucional. Rio de Janeiro: Renovar. 2005. p. 476.

${ }_{550}$ MARTINS, Raphael Manhães. Inadimplemento antecipado: perspectiva para a sua aplicação no Direito brasileiro. Revista Forense, Rio de Janeiro, v. 391, ano 103, mai./jun. 2007, p. 217.

${ }^{551}$ TJSP, Agravo de Instrumento $\mathrm{n}^{\circ}$ 3066174100, $3^{\text {a }}$ Câmara de Direito Privado, Rel. Desembargador Francisco Loureiro, j. 13.03.2006.
} 
derivar de uma violação a dever anexo decorrente da boa-fé objetiva. Confira-se, a seguir, trecho que bem sintetiza o posicionamento do referido autor:

\begin{abstract}
Contudo, é de se questionar se os casos de vencimento antecipado configurariam sempre violação positiva, na medida em que são variadas as hipóteses abrangidas pelo conceito. Quando a prestação em si não é realizada, e restar claro que não o será no momento devido, parece não haver dúvida sobre tratar-se da antecipação do inadimplemento absoluto, ou da mora, com o que se torna possível, em tese, a resolução do contrato. Por sua vez, se o ato de inadimplemento se limita à declaração do devedor, mesmo séria, sem que esta não implique diretamente a não-realização da prestação (como ocorreria nas obrigações de fazer personalíssimas), a hipótese pode ser enquadrada na mora, pois a manifestação do devedor não afasta o direito do credor à prestação, ainda que torne bastante provável a necessidade de execução coativa. Por fim, quando o descumprimento antecipado for conectável a deveres laterais (o devedor, por sua conduta, rompe o vínculo de confiança e põe em riso a pessoa do credor, ainda que nenhum dano tenha se concretizado), há violação positiva, inegavelmente.

Como se constata, nem todos os casos de inadimplemento antecipado se incluem no âmbito da violação positiva, ao contrário do que entendia Staub, a propósito do direito alemão. ${ }^{552}$
\end{abstract}

Entretanto, não se pode concordar com o posicionamento doutrinário de que o fundamento do inadimplemento antecipado repousa na violação positiva do contrato, haja vista as críticas e questionamentos a sua utilidade que realizamos no primeiro capítulo dessa dissertação.

Como exposto anteriormente, ao se adotar o entendimento segundo o qual todos os deveres que compõem a relação obrigacional estão abrangidos na noção de prestação devida, não haveria espaço para se falar em violação positiva do contrato. A violação de qualquer dever obrigacional abalará a prestação devida e obstruirá o caminho em direção ao resultado útil programado, o que caracteriza situação de inadimplemento (em sentido lado). A consequência da violação da prestação devida - mora ou inadimplemento absoluto -, por sua vez, dependerá da possibilidade do credor ainda receber a prestação e da sua utilidade para o credor.

Assim, guardando coerência com o que foi exposto acerca da violação positiva do contrato, cuja conclusão nos levou a negar a necessidade de elaboração de uma terceira

552 SILVA, Jorge Cesa Ferreira da. Inadimplemento das obrigações. São Paulo: Editora Revista dos Tribunais. 2007. p 46. 
hipótese de inadimplemento, acreditamos que seria melhor qualificar o inadimplemento antecipado como uma situação ordinária de inadimplemento, que pode culminar em inadimplemento absoluto ou mora, a depender da possibilidade de cumprimento da prestação (na acepção técnico-jurídica da palavra "possibilidade") e da permanência de utilidade da prestação para o credor. ${ }^{553}$

Aplicam-se aqui os mesmos critérios que apresentamos no primeiro capítulo para a caracterização de mora ou inadimplemento absoluto. $\mathrm{O}$ inadimplemento antecipado configuraria uma hipótese de inadimplemento absoluto ("inadimplemento antecipado absoluto") se o devedor retarda ou omite ato necessário ao adimplemento da prestação ou descumpre dever de conduta (i) de modo a tornar a prestação devida impossível de ser adimplida no termo pactuado, ou (i) que inviabiliza o cumprimento da prestação devida no termo ajustado entre as partes, de maneira que a prestação, em razão do atraso, se torna inútil para o credor.

Por outro lado, o inadimplemento antecipado ensejaria uma hipótese de mora ("mora antecipada") nos casos em que o atraso ou a omissão de atos necessários ao adimplemento ou a inobservância do dever de conduta ensejar apenas o retardamento da prestação, sem lhe tirar a utilidade para o credor, ou seu cumprimento defeituoso.

Ressalte-se que cabe ao credor o ônus de provar que a prestação, em razão da hipótese de inadimplemento antecipado, tornou-se impossível ou perdeu a sua utilidade, ocorrendo uma situação de inadimplemento absoluto, salvo se o termo for essencial, hipótese em que a inutilidade decorre da própria natureza do termo ${ }^{554}$.

\footnotetext{
${ }^{553}$ Neste mesmo sentido: “[...] qualquer que seja o suporte fático objetivo [do inadimplemento antecipado], o que resta violado, ao fim e ao cabo, é a prestação devida, seja por faltar elemento essencial à execução do comportamento devido - vontade - a impedir o recebimento da prestação pelo credor, seja por se tornar a prestação impossível para o devedor ou inútil para o credor. Não importa o meio pelo qual a prestação é violada, se por inobservância de dever de conduta, de dever secundário de prestação etc. O que importa é a repercussão dessa inobservância no adimplemento da prestação devida”. TERRA, Aline de Miranda Valverde. Inadimplemento anterior ao termo. Rio de Janeiro: Renovar. 2009. p. 229.

${ }^{554}$ Confiram-se os ensinamentos de Agostinho Alvim: "Dada a alegação do credor de que a prestação, devido à mora, não lhe representa mais utilidade, a ele cabe o ônus da prova. Não é o devedor que está sujeito a provar que a prestação continua sendo útil. Esta utilidade presume-se porque, via de regra, a mora ocasiona prejuízo ao credor, mas só excepcionalmente tornará inútil a prestação. Por isso a lei admite purgação. Assim
} 
Por fim, vale mencionar que a não verificação do termo contratual não é obstáculo para a caracterização do inadimplemento absoluto ou da mora, haja vista que a análise funcionalizada do termo permite reconhecer a exigibilidade da prestação mesmo antes do seu avento nas hipóteses em que ele não mais exercer a função para a qual foi concebido $^{555}$.

E essa é, exatamente, a hipótese em tela: violado dever obrigacional antes do advento do termo, o benefício do termo não merece mais tutela do ordenamento jurídico, já que deixa de cumprir a sua função de conferir prazo para o devedor adimplir perfeitamente a prestação devida. Assim, a prestação passa a ser imediatamente exigível e torna-se viável a configuração do inadimplemento absoluto ou da mora.

\section{7. Âmbito de aplicação do inadimplemento antecipado}

Depois de examinados os suportes fáticos do inadimplemento antecipado e demonstrada a sua distinção em relação ao risco de descumprimento contratual, impõe-se analisar o âmbito de aplicação do instituto para verificar em quais tipos de relações jurídicas ele pode ser utilizado.

\subsubsection{Obrigações a termo}

O inadimplemento antecipado é instituto do direito das obrigações. Diferentemente do sistema legal da common law ${ }^{556}$, o inadimplemento antecipado incide apenas em relações obrigacionais, ou seja, nas relações caracterizadas por um vínculo

sendo, ao invocar a inutilidade cabe a prova." ALVIM, Agostinho. Da inexecução das obrigações e suas consequências. 3. ed. atual. Rio de Janeiro: Editora Jurídica e Universitária Ltda. 1949. p. 69.

${ }_{555}$ TERRA, Aline de Miranda Valverde. Inadimplemento anterior ao termo. Rio de Janeiro: Renovar. 2009. p. 232 .

${ }_{556}$ Nesse sentido, Aline Terra afirma que "[...] no âmbito da common law, aplica-se a teoria da anticipatory breach of contract a rompimentos de noivado. Sustenta-se que as partes teriam o direito de não ter seu contrato [de noivado] repudiado antecipadamente, em razão do que se designa 'fiction of an implied promise",. TERRA, Aline de Miranda Valverde. Inadimplemento anterior ao termo. Rio de Janeiro: Renovar. 2009. p. 196. 
jurídico pendente entre dois indivíduos, direcionado à satisfação do interesse do credor e cujo objeto seja uma prestação economicamente apreciável ${ }^{557}$.

O inadimplemento antecipado do contrato, como o próprio nome sugere, apenas tem lugar em obrigações a termo ${ }^{558}$, cuja execução é diferida (seja instantânea ou continuada). O adjetivo encontrado na expressão "inadimplemento antecipado" aponta para o fato de que a violação à prestação ocorre antes do tempo devido, de maneira adiantada. ${ }^{559}$ Daí concluir-se que somente é possível um paradigma temporal nas obrigações quando a sua eficácia se submete a um evento futuro e certo, o termo.

Mais precisamente, o termo deve ser final ${ }^{560}$. O termo também deve ter sido estipulado em benefício do devedor, ou em benefício de ambas as partes, para que se possa justificar a imediata exigibilidade da obrigação em caso de inadimplemento antecipado, situação em que o devedor adota um comportamento tal que deixa fazer jus ao benefício do termo que lhe foi concedido para o cumprimento da sua obrigação. É inconcebível inadimplemento antecipado quando o termo é posto em benefício exclusivo do credor.

Aline Terra ressalta que dentre as obrigações a termo existe uma categoria mais propensa a servir de cenário a um inadimplemento antecipado, que é aquela que "se

\footnotetext{
557 Embora haja alguma divergência, a doutrina majoritária entende que a obrigação tem conteúdo essencialmente patrimonial. Aduz-se que não obstante deveres jurídicos em geral possam ter conteúdo não patrimonial, esses casos não seriam enquadrados no conceito estrito de obrigação. Nesse sentido, as obrigações, espécies que são dos deveres jurídicos, teriam conteúdo exclusivamente patrimonial - o que não afasta, por certo, que delas surjam interesses não patrimoniais. É possível mencionar. PEREIRA, Caio Mário da Silva. Instituições de Direito Civil. vol. II. 20. ed. Rio de Janeiro: Forense, 2005. p. 21-23. GONÇALVES, Carlos Roberto. Direito civil brasileiro. v. 2: Teoria geral das obrigações. 8. ed. São Paulo: Saraiva. 2011. p. 27.

558 Segundo Carlos Roberto Gonçalves, “obrigação a termo (ou a prazo) é aquela em que as partes subordinam os efeitos do negócio jurídico a um evento futuro e certo”. GONÇALVES, Carlos Roberto. Direito civil brasileiro. v. 2: Teoria geral das obrigações. 8. ed. São Paulo: Saraiva. 2011. p. 204.

${ }^{559}$ Vale mencionar o entendimento de Aline Terra, segundo o qual a expressão que demonstraria com maior precisão a essência do instituto seria "inadimplemento anterior ao termo". TERRA, Aline de Miranda Valverde. Inadimplemento anterior ao termo. Rio de Janeiro: Renovar. 2009. p. 121-122. Neste trabalho, optamos por adotar a expressão "inadimplemento antecipado do contrato" na maioria das vezes por ser a expressão mais utilizada na doutrina.

${ }^{560}$ Sobre o conceito de termo final: "Nas obrigações a prazo, o termo pode ser inicial ou final. Se é inicial, há uma dilação entre o momento em que a obrigação se constitui e o momento do adimplemento. Se é final, determina quando deve ser cumprida. O termo final apõe-se às obrigações de prestações contínuas." GOMES, Orlando. Obrigações. 16. ed. rev., atual. e aum., de acordo com o Código Civil de 2002, por Edvaldo Brito. Rio de Janeiro: Forense. 2005. p. 119.
} 
caracteriza pelo fato de ser necessariamente de execução diferida ao menos em relação à elaboração da prestação", exigindo "o cumprimento de uma série de atos preparatórios e/ou executivos ao longo do prazo que medeia a celebração do contrato e o termo ajustado",561. $^{\text {. }}$

Assiste razão à referida autora, pois é nesse tipo de obrigação que é mais importante que o comportamento do devedor sempre demonstre que ele pretende e atua de maneira a adimplir no tempo, modo e lugar pactuados entre as partes. Note-se, todavia, que qualquer obrigação sujeita a termo final, ainda que não demande atos preparatórios ou atos de execução, pode ser inadimplida antecipadamente, seja em virtude de declaração expressa de não querer adimplir ou da violação de deveres obrigacionais que impossibilitem ou tornem inútil a prestação para o credor.

\subsubsection{Contrato Preliminar}

Cumpre analisar se o instituto do inadimplemento antecipado pode ser aplicado aos contratos preliminares. Caio Mário da Silva Pereira define contrato preliminar como "aquele por via do qual ambas as partes ou uma delas se comprometer a celebrar mais tarde outro contrato, que será contrato principal" ${ }^{, 562}$. De maneira geral, o contrato preliminar é conceituado como um negócio jurídico bilateral de acordo com o qual as partes se comprometem a emitir, futuramente, novas declarações de vontade, objetivando a concretização de um outro negócio jurídico, que será chamado de definitivo ${ }^{563}$. O contrato preliminar pode ter por objeto a realização de qualquer contrato definitivo, de qualquer espécie. O seu campo mais frequente é, entretanto, o contrato preliminar de compra e venda ou promessa de compra e venda.

Enzo Roppo acentua com clareza que a peculiaridade do contrato preliminar é que:

561 TERRA, Aline de Miranda Valverde. Inadimplemento anterior ao termo. Rio de Janeiro: Renovar. 2009. p. 199.

${ }_{562}$ PEREIRA, Caio Mario da Silva. Instituições de Direito Civil. v. III. Rio de Janeiro, Forense. 2006. p. 81.

${ }^{563}$ AZEVEDO, Fábio de Oliveira. Algumas questões de direito civil e de direito processual civil sobre o contrato preliminar. In: HIRONAKA, Giselda Maria Fernandes Novaes; TARTUCE, Flávio (Coord.). Direito contratual. Temas Atuais. São Paulo: Método. 2007. p. 402. 
[...] as partes já definiram os termos essenciais da operação econômica que tencionam realizar (suponhamos, a venda de um imóvel por um certo preço), mas não querem passar de imediato a atuá-la juridicamente, não querem concluir, desde já, o contrato produtor dos efeitos jurídico-econômicos próprios da operação; preferem remeter a produção de tais efeitos para um momento subsequente, mas, ao mesmo tempo, desejam a certeza de que estes efeitos se produzirão no tempo oportuno, e por isso não aceitam deixar para o futuro cumprimento da operação à boa vontade, ao sentido ético, à correção recíproca, fazendo-a, ao invés, desde logo matéria de vínculo jurídico. Estipulam, então, um contrato preliminar, do qual nasce precisamente a obrigação de concluir, no futuro, o contrato definitivo, e, com isso, de realizar efetivamente a operação econômica perseguida. ${ }^{564}$

O contrato preliminar se diferencia do principal pelo seu objeto, que no preliminar é a obrigação de concluir o outro contrato, enquanto que o do definitivo é uma prestação substancial ${ }^{565}$. O contrato preliminar não se confunde com as negociações preliminares ou tratativas. É que estas nada mais são do que uma etapa do processo de formação contratual, momento em que as partes exteriorizam de diversas maneiras a sua intenção de contratar, e não são dotadas de obrigatoriedade. Só se pode falar de contrato preliminar quando as conversas das partes avançarem para uma proposta que se faça acompanhar de aceitação ${ }^{566}$.

O Código Civil de 2002 dedicou uma seção ao contrato preliminar (artigos 462 a 466), exigindo que contenha todos os requisitos do contrato definitivo, salvo quanto à forma, e seja levado ao registro competente ${ }^{567}$. O contrato preliminar pode ser unilateral ou bilateral. É unilateral quando, perfeito pelo consentimento de ambas as partes, produz obrigações para apenas uma parte. A opção de compra, a venda a contento e a promessa de doação são exemplos de contrato preliminar unilateral ${ }^{568}$. É bilateral quando gera obrigações para ambos os contratantes, ficando desde logo programado o contrato definitivo, como dever recíproco, obrigadas ambas as partes a dar-lhe seu

\footnotetext{
${ }^{564}$ ROPPO, Enzo. O contrato. Trad. de Ana Coimbra e M. Januário C. Gomes. Coimbra: Livraria Almedina. 1988. p. 102-103.

${ }^{565}$ PEREIRA, Caio Mario da Silva. Instituições de direito civil. v. III. Rio de Janeiro: Forense. 2006. p. 81. ${ }^{566}$ AZEVEDO, Fábio de Oliveira. Algumas questões de direito civil e de direito processual civil sobre o contrato preliminar. In: HIRONAKA, Giselda Maria Fernandes Novaes; TARTUCE, Flávio (Coord.). Direito Contratual. Temas Atuais. São Paulo: Método. 2007. p. 402.

567 "Art. 462. O contrato preliminar, exceto quanto à forma, deve conter todos os requisitos essenciais ao contrato a ser celebrado."

${ }^{568}$ GOMES, Orlando. Contratos. Rio de Janeiro: Forense. 2008. p. 163.
} 
consentimento $^{569}$. A espécie mais comum de contrato preliminar bilateral é a promessa de venda, que pode conter cláusula de arrependimento ou ser irretratável, criando, nesta última hipótese, direito real ${ }^{570}$.

Comporta o contrato preliminar a aposição de condição e de termo. Caso o termo tenha sido previsto, o devedor estará constituído em mora automaticamente; caso o termo não seja avençado, a parte interessada na constituição em mora terá de interpelar a outra para que o cumpra, no prazo que for fixado. Todavia, pode ocorrer do cumprimento do contrato preliminar bilateral exigir para a sua execução a participação do credor (pagamento de impostos, comparecimento a cartório, assinatura de instrumento, etc.), o que tornará necessário, mesmo com prazo ajustado, o envio de notificação ao devedor, determinando o tempo e o lugar do cumprimento ${ }^{571}$.

$\mathrm{Na}$ hipótese de inadimplemento do contrato preliminar, o Código Civil ${ }^{572}$ contemplou a possibilidade do juiz, a pedido do interessado, suprir a vontade da parte inadimplente, conferindo caráter definitivo ao contrato preliminar, salvo se a isto se opuser a natureza da obrigação. A sentença proferida na ação intentada pelo credor é de natureza constitutiva, valendo como título aquisitivo do direito. A sentença equivale ao próprio contrato que era a prestação ajustada no contrato preliminar ${ }^{573}$. À parte credora também foi resguardado o direito, em caso de inadimplemento da obrigação, de considerar o contrato resolvido e pleitear perdas e danos.

Entende-se que o inadimplemento antecipado também pode ser aplicado aos contratos preliminares. É perfeitamente possível que, antes do advento do termo, o devedor

\footnotetext{
${ }^{569}$ PEREIRA, Caio Mario da Silva. Instituições de direito civil. v. III. Rio de Janeiro: Forense. 2006. p. 8384.

${ }^{570}$ GOMES, Orlando. Contratos. Rio de Janeiro: Forense. 2008. p. 163.

${ }^{571}$ PEREIRA, Caio Mario da Silva. Instituições de direito civil. v. III. Rio de Janeiro: Forense. 2006. p. 86.

572 “Art. 463. Concluído o contrato preliminar, com observância do disposto no artigo antecedente, e desde que dele não conste cláusula de arrependimento, qualquer das partes terá o direito de exigir a celebração do definitivo, assinando prazo à outra para que o efetive.

Parágrafo único. O contrato preliminar deverá ser levado ao registro competente."

“Art. 464. Esgotado o prazo, poderá o juiz, a pedido do interessado, suprir a vontade da parte inadimplente, conferindo caráter definitivo ao contrato preliminar, salvo se a isto se opuser a natureza da obrigação."

“Art. 465. Se o estipulante não der execução ao contrato preliminar, poderá a outra parte considerá-lo desfeito, e pedir perdas e danos."

${ }^{573}$ PEREIRA, Caio Mario da Silva. Instituições de direito civil. v. III. Rio de Janeiro: Forense. 2006. p. 92.
} 
descumpra antecipadamente a obrigação de fazer consistente no objeto do contrato preliminar, ou mesmo dever anexo decorrente do princípio da boa-fé que afete diretamente o objeto do contrato preliminar, a ensejar o seu inadimplemento antecipado.

Isso porque, quando as partes acordarem definitivamente quanto aos elementos essenciais e secundários do contrato, fixando o termo do cumprimento da obrigação (celebração do contrato definitivo), esta obrigação de fazer pode ser rompida antecipadamente pelo devedor da obrigação, quer por declaração expressa, quer por manifestação tácita ou por comportamento que torne impossível a celebração do contrato definitivo ${ }^{574}$.

Com efeito, não são raros os casos de contratos preliminares em que as partes assumem a obrigação de assinar um contrato definitivo e, antes do vencimento do prazo para a assinatura do contrato definitivo, e por motivo de encontrarem melhores preços e condições, as partes contratam com terceiro quebrando dessa forma o contrato preliminar anterior $^{575}$.

É o que acontece, por exemplo, no contrato preliminar cujo objeto consiste na celebração de contrato de distribuição definitivo, por meio do qual " $\mathrm{A}$ " concederá a "B" o direito de se tornar distribuidor exclusivo de um dado produto em certa região por um período determinado. No entanto, antes da celebração do contrato definitivo, "A" celebra com "C" contrato de distribuição com o mesmo objeto. O comportamento de "A" tornou impossível a celebração do contrato de distribuição definitivo entre "A" e "B" e, por via de consequência, acarretou o inadimplemento antecipado daquele contrato preliminar.

Também pode ser mencionado o caso em que uma empresa "A" está passando por uma grave crise econômico-financeira e celebra um contrato preliminar com uma empresa de consultoria "B" cujo objeto consiste na celebração de contrato de prestação de serviços definitivo, por meio do qual "B" lhe prestará serviços de consultoria,

\footnotetext{
${ }^{574}$ AZULAY, Fortunato. Do inadimplemento antecipado do contrato. Rio de Janeiro: Editora Brasília/Rio. 1977. p. 96.

575 AZULAY, Fortunato. Do inadimplemento antecipado do contrato. Rio de Janeiro: Editora Brasília/Rio. 1977. p. 97, nota de rodapé 97.
} 
planejamento, gestão, etc. Todavia, antes das partes celebrarem o contrato definitivo, "A" toma conhecimento que "B" divulgou informações confidenciais a seu respeito a terceiros, o que caracteriza a quebra dos deveres de confidencialidade e sigilo. A violação desse dever anexo poderá ensejar, a depender da gravidade das informações reveladas, o inadimplemento antecipado do contrato preliminar.

Portanto, no que tange ao objeto do presente estudo, não há óbice para a configuração do inadimplemento antecipado nos contratos preliminares. Em todos os casos mencionados acima, o repúdio antecipado ao contrato preliminar e/ou a falta de boa-fé do comportamento de uma das partes após a assinatura do contrato preliminar podem levar à caracterização do inadimplemento antecipado e aos efeitos jurídicos daí decorrentes.

\subsubsection{Contratos Bilaterais e Unilaterais}

Cumpre verificar se o instituto do inadimplemento antecipado pode ser aplicado tanto a contratos bilaterais como unilaterais. Dentre as diversas classificações dos contratos, encontramos a que os distingue em razão das obrigações atribuídas a cada parte. Define-se como unilateral o contrato que cria obrigações para um só dos contratantes; bilateral, aquele que as origina para ambos. No contrato unilateral, há um credor e um devedor; no bilateral, cada uma das partes é credora e reciprocamente devedora da outra ${ }^{576}$.

Como analisado anteriormente, o prisma dinâmico, complexo e funcional do direito das obrigações determina que em qualquer relação obrigacional ambas as partes deverão cumprir diversos deveres anexos decorrentes do princípio da boa-fé objetiva. Esta perspectiva, em princípio, afastaria a higidez da classificação dos contratos em bilaterais e unilaterais, uma vez que todas as relações obrigacionais comportam deveres para ambas as partes. No entanto, o traço distintivo mais importante na classificação dos contratos bilaterais não é a mera atribuição de deveres às partes, mas sim a correspondência existente entre os deveres principais, surgindo o sinalagma contratual.

\footnotetext{
${ }^{576}$ PEREIRA, Caio Mário da Silva. Instituições de direito civil. v. III. Rio de Janeiro: Forense. 2006. p. 66.
} 
Contratos bilaterais, também chamados de sinalagmáticos, caracterizam-se pela circunstância de a prestação de cada uma das partes encontrar sua justificativa e seu fundamento na prestação da contraparte [do ut des, do ut facias, facio ut facias, facio ut des]. Nestes contratos chamados de sinalagmáticos uma obrigação é a causa da outra, havendo conexão essencial entre as prestações devidas e dependência recíproca das obrigações. Confira-se o que afirma, acerca do conceito de sinalagma, Orlando Gomes:

\begin{abstract}
Não é pacífica a noção de contrato bilateral. Para alguns, assim deve qualificarse todo contrato que produz obrigações para as duas partes, enquanto para outros a sua característica é o sinalagma, isto é, a dependência recíproca das obrigações, razão porque preferem chamá-los contratos sinalagmáticos ou de prestações correlatas. Realmente, nesses contratos, uma obrigação é a causa, a razão de ser, o pressuposto da outra, verificando-se interdependência essencial entre as prestações. ${ }^{577}$
\end{abstract}

Destaque-se que existem dois tipos de sinalagma, quais sejam, o genético e o funcional. O sinalagma genético se refere à vinculação entre os deveres de prestar que são assumidos pelas partes no momento da celebração do contrato. $\mathrm{O}$ sinalagma funcional, por sua vez, expressa a ideia de permanência dos deveres de prestar durante a relação contratual. Nos contratos sinalagmáticos, o vínculo que, segundo a vontade dos contratantes, acompanha o contrato desde o seu nascimento (sinalagma genético), continua a manifestar-se durante todo o período da execução do negócio (sinalagma funcional) ${ }^{578}$.

É interessante observar os apontamentos de Antunes Varela sobre a distinção entre sinalagma genético e funcional:

Fala-se em sinalagma genético para significar que, na gênese ou raiz do contrato, a obrigação assumida por cada um dos contratantes constitui a razão de ser da obrigação contraída por outro. O sinalagma funcional aponta essencialmente para a idéia de que as obrigações têm de ser exercidas em paralelo (visto que a execução de cada uma delas constitui, na intenção dos contratantes, o pressuposto lógico do cumprimento da outra) e ainda para o pensamento de que todo acidente ocorrido na vida de uma delas repercute necessariamente no ciclo vital da outra. ${ }^{579}$

577 GOMES, Orlando. Contratos. Rio de Janeiro: Forense. 2008. p. 85.

${ }^{578}$ GOMES, Orlando. Contratos. Rio de Janeiro: Forense. 2008. p. 85.

${ }^{579}$ VARELA, ANTUNES. Das obrigações em geral. v. I. Coimbra: Coimbra Editora. 2000, p.397. 
Os contratos unilaterais, por sua vez, são aqueles em que não existem obrigações principais ligadas por um nexo de interdependência ou correspectividade (o sinalagma). É possível que a ambas as partes sejam atribuídas obrigações, mas uma não é causa e consequência da outra, posto que as obrigações são autônomas e independentes, desvinculadas de qualquer contraprestação da outra parte.

A importância da classificação entre contratos bilaterais e unilaterais reside no fato de alguns institutos, remédios e consequências jurídicas se aplicarem exclusivamente aos contratos bilaterais, justamente porque visam à manutenção do sinalagma funcional. É o que comenta Carlos Roberto Gonçalves: "podem ser apontadas algumas vantagens práticas da distinção entre contratos unilaterais e bilaterais: a) a exceptio non adimpleti contractus e a cláusula resolutiva tácita somente se amoldam ao contrato bilateral, que requer prestações simultâneas, não podendo um dos contratantes, antes de cumprir sua obrigação, exigir o implemento da do outro (CC, art. 476, primeira parte); b) a teoria dos riscos só é aplicável ao contrato bilateral, no qual se deverá apurar qual dos contratantes sofrerá as consequências da perda da coisa devida ou da impossibilidade da prestação." É com base nesse tipo de distinção relacionada ao sinalagma que se discute a aplicação do inadimplemento antecipado aos contratos unilaterais.

Não se questiona a admissibilidade da aplicação da teoria do inadimplemento antecipado em relação aos contratos bilaterais. No que diz respeito aos contratos unilaterais, todavia, discute-se a possibilidade de caracterização do inadimplemento antecipado. Fortunato Azulay, por exemplo, baseando-se na teoria do anticipatory breach of contract, assinala que não há sinalagmaticidade a ser resguardada nos contratos unilaterais, refutando a aplicação do inadimplemento antecipado a esses contratos. De acordo com o referido autor, é "na cláusula ou condição resolutiva tácita dos contratos bilaterais que se encontra a chave da resolução antecipada do contrato de execução a termo" ${ }^{, 581}$. Em palavras mais elucidativas,

\footnotetext{
${ }^{580}$ GONÇALVES, Carlos Roberto. Direito civil brasileiro. v. 2: Teoria geral das obrigações. 8. ed. São Paulo: Saraiva. 2011. p. 93-94.

${ }^{581}$ AZULAY, Fortunato. Do inadimplemento antecipado do contrato. Rio de Janeiro: Editora Brasília/Rio. 1977. p. 53.
} 
Quando somente uma parte é obrigada ao cumprimento da sua prestação, a doutrina não é considera o repúdio como inadimplência. Tal é o caso das obrigações de pagamento em dinheiro, inclusive nas cambiais, em que os tribunais se recusam a admitir a execução da obrigação antes do vencimento. Baseada no clássico precedente FROST v. KNIGHT, a Suprema Corte dos EUA não admite que a doutrina do anticipatory breach se estenda às obrigações unilaterais de pagamento em dinheiro, a não ser nos casos de prestações continuadas e dependentes de recíproca prestação da outra parte. Neste caso, porém, já estaria estabelecida a bilateralidade. ${ }^{582}$

Em sentido oposto, Aline Terra afirma que o inadimplemento antecipado do contrato está configurado sempre que o devedor, antes do advento do termo, se torne, desde logo, inadimplente, "qualquer que seja a natureza jurídica do contrato celebrado",583, concluindo pela possibilidade da configuração do inadimplemento antecipado em promessa de contrato de doação, assim, como em contratos de mandato, ambos espécies de contrato unilateral.

Entendemos que assiste razão à autora. Salvo melhor juízo, o instituto do inadimplemento antecipado não se relaciona, sempre e necessariamente, à manutenção do sinalagma e não se fundamenta na cláusula resolutória tácita dos contratos bilaterais. Embora isso seja verdade na maioria dos casos, considera-se que o fundamento do inadimplemento antecipado é o princípio da boa-fé objetiva. São a boa-fé e a confiança que nortearão a caracterização do inadimplemento antecipado em todas as circunstâncias.

Nesse sentido, Raphael Manhães Martins indica que os elementos objetivos caracterizadores do inadimplemento antecipado sempre terão sua gênese na violação da boa-fé ou da confiança:

\footnotetext{
O inadimplemento antecipado, dependendo do comportamento do obrigado, pode conduzir ou a uma violação ao princípio da boa-fé objetiva, e/ou uma violação à confiança da outra parte. Nesse sentido, estar-se-á diante de uma violação ao princípio da boa-fé objetiva quando o devedor violar algum dos deveres impostos pelo princípio, como ocorre: i) quando o obrigado coloca-se em posição de impossibilidade de adimplir com a prestação; ii) quando o devedor se recusa tacitamente a realizar o cumprimento da obrigação. Por outro
}

\footnotetext{
582 AZULAY, Fortunato. Do inadimplemento antecipado do contrato. Rio de Janeiro: Editora Brasília/Rio. 1977. p. 119-120.

583 TERRA, Aline de Miranda Valverde. Inadimplemento anterior ao termo. Rio de Janeiro: Renovar. 2009. p. 206.
} 
lado, há uma violação do princípio da proteção da confiança legítima quando o devedor iii) recusa-se a cumprir a prestação que lhe é imposta. ${ }^{584}$

Assim, parece evidente que o alicerce, o motivo justificante da viabilidade do inadimplemento antecipado no direito brasileiro é a cláusula de boa-fé objetiva, que exige das partes um comportamento probo e honesto, instalando a cooperação recíproca das partes a fim de produzir o resultado útil programado. Qualquer que seja o suporte fático que der causa ao inadimplemento antecipado (uma declaração de não adimplir ou um comportamento que impossibilite ou inutilize a obrigação), ele sempre veiculará um comportamento avesso àqueles ditames exarados pela boa-fé objetiva.

É sob essa luz que se entende que não há qualquer obstáculo à configuração do inadimplemento antecipado nos contratos unilaterais. $\mathrm{O}$ inadimplemento antecipado se caracterizará sempre que uma parte tiver um comportamento que impossibilite ou inutilize, desde já, o cumprimento da obrigação que lhe incumbe no tempo, modo e lugar pactuados, quebrando a confiança e a legítima expectativa da outra parte, independentemente do tipo do contrato (bilateral ou unilateral).

Para melhor visualizar a possibilidade de caracterização de inadimplemento antecipado em um contrato unilateral, imagine-se a seguinte situação: "A" celebra uma promessa de doação com "B”, comprometendo-se a doar-lhe um determinado automóvel dali a três meses. No entanto, um mês antes do advento do termo, "A" declara que desistiu da doação e não cumprirá a promessa, ou doa o mesmo automóvel para " $C$ "585.

Entende-se que, nesse caso, deve ser admitido o inadimplemento antecipado da promessa de doação ${ }^{586}$ para proteger a boa-fé, a confiança e a legítima expectativa

\footnotetext{
${ }^{584}$ MARTINS, Raphael Manhães. Inadimplemento antecipado: perspectiva para a sua aplicação no Direito brasileiro. Revista Forense, Rio de Janeiro, v. 391, ano 103, mai./jun. 2007, p. 217.

${ }^{585} \mathrm{O}$ exemplo foi adaptado de TERRA, Aline de Miranda Valverde. Inadimplemento anterior ao termo. Rio de Janeiro: Renovar. 2009. p. 206.

586 A promessa de doação é aceita de maneira unânime pela doutrina, conforme observa Washington de Barros Monteiro: "Contesta-se geralmente a viabilidade jurídica da promessa de doação, isto é, a possibilidade de existir contrato preliminar unilateral, visando à constituição de liberalidade futura. Consoante magistério de MESSINEO, duas são as razões, uma de ordem histórica, outra de ordem dogmática, justificativas de semelhante impossibilidade: sempre se entendeu, em todos os tempos, que não podem ser objeto de doação bens futuros; além disso, deve esta primar pela espontaneidade, operando-se
} 
depositadas pelo promissário na promessa de doação feita pelo outro contratante. Embora a doação seja uma liberalidade, quando o promitente doador manifestou a sua vontade de doar e criou uma legitima expectativa na outra parte, ele não poderá simplesmente desistir da doação se não houver um justo motivo para tanto ${ }^{587}$. Admitida a força obrigatória da promessa de doação, o promitente-doador que declara antecipadamente que não irá adimplir, ou que adota um comportamento incompatível com o adimplemento, autorizará o promitente-donatário a considerar a promessa de doação antecipadamente inadimplida e a invocar as consequências daí decorrentes ${ }^{588}$.

Importante exemplo prático da promessa de doação pode ser oferecido com os acordos de separação judicial, hoje possíveis até mesmo pela via extrajudicial (Lei $\mathrm{n}^{\circ}$ 11.441/2007), nos quais os cônjuges se comprometem a realizar um contrato de doação para a prole do casal, normalmente de um imóvel que integra a propriedade comum do casal $^{589}$. A $3^{\text {a }}$ Turma do STJ, no julgamento do REsp 125859, decidiu, por unanimidade, que "a promessa de doação obriga, se não foi feita por liberalidade, mas como condição para o desquite". Por sua vez, a $4^{\text {a }}$ Turma do STJ, por maioria, no julgamento do REsp 30647, entendeu ser inválida a promessa de doação feita em separação judicial, dizendo que "tratando-se de mera liberalidade, uma promessa de doação sem encargo, é ela por

nullo jure cogente, o que se não compadece com o caráter vinculatório inerente à obrigação de fazer, contida numa promessa de doação.

Inexiste, porém, razão para excluir tal promessa, cuja possibilidade jurídica é expressamente admitida pelo direito alemão (BGB, art. 2.301). Ela não contraria qualquer princípio de ordem pública e dispositivo algum a proíbe." MONTEIRO, Washington de Barros. Curso de direito civil: Direito das obrigações. $2^{\mathrm{a}}$ parte: dos contratos em geral, das várias espécies de contrato, dos atos unilaterais, da responsabilidade civil. MONTEIRO, Washington de Barros; MALUF, Carlos Alberto Dabus; SILVA, Regina Beatriz Tavares da. 36. ed. São Paulo: Saraiva, 2009. p. 147-148.

${ }^{587}$ MORAES, Maria Celina Bodin de. Notas sobre a Promessa de Doação. Revista Trimestral de Direito Civil. Rio de Janeiro, n. 21, jan./mar. 2005, p. 17. No mesmo sentido: "pode ela [a promessa de doação] ser formulada, por exemplo, pelos cônjuges, em processo de separação consensual, em benefício dos filhos do casal, executando-se posteriormente a relação jurídica, em caso de inadimplemento, em conformidade com o art. 639 do atual Código de Processo Civil." MONTEIRO, Washington de Barros. Curso de direito civil: Direito das obrigações. $2^{\text {a }}$ parte: dos contratos em geral, das várias espécies de contrato, dos atos unilaterais, da responsabilidade civil. MONTEIRO, Washington de Barros; MALUF, Carlos Alberto Dabus; SILVA, Regina Beatriz Tavares da. 36. ed. São Paulo: Saraiva. 2009. p. 148.

${ }^{588}$ Em sentido contrário, Caio Mário da Silva Pereira sustenta ser inexigível o cumprimento da promessa de doação pura, porque esta representa liberalidade plena. PEREIRA, Caio Mario da Silva. Instituições de direito civil. v. III. Rio de Janeiro, Forense. 2006. p. 257-258.

${ }_{589}$ AZEVEDO, Fábio de Oliveira. Algumas questões de direito civil e de direito processual civil sobre o contrato preliminar. In: HIRONAKA, Giselda Maria Fernandes Novaes; TARTUCE, Flávio (Coord.), Direito contratual. Temas Atuais. São Paulo: Método. 2007. p. 406. 
natureza retratável; enquanto não formalizada a doação; é licito ao promitente-doador arrepender-se".

Diante da divergência de entendimentos entre as duas turmas, a $2^{\mathrm{a}}$ Seção do STJ foi instada a se pronunciar, decidindo no julgamento do EResp 125859, por maioria, que "o acordo celebrado quando do desquite amigável, homologado por sentença, que contém promessa de doação de bens do casal aos filhos, é exigível em ação cominatória". No entanto, no voto vencedor consta a ressalva de que a exigibilidade da promessa de doação é específica para as hipóteses de separação judicial, em que a manifestação de vontade é homologada judicialmente, não alcançando hipóteses em que ela é feita de maneira pura e simples, como ato típico de liberalidade.

Todavia, ousamos respeitosamente discordar da orientação majoritária do STJ, para sustentar que a promessa de doação será sempre válida, pouco importando se é pura e simples ou, ainda, se é específica para o acordo de separação judicial, em benefício dos filhos do casal. Não parece compatível com o paradigma da boa-fé e da eticidade, sobre o qual devem gravitar todas as relações jurídicas obrigacionais, que se permita a alguém se comprometer a celebrar um futuro contrato de doação em proveito de outrem, para mais tarde recusar-se a fazê-lo, ferindo a legítima expectativa da pessoa que acreditou que se tornaria donatária ${ }^{590}$. Assim, admitido o caráter obrigatório das promessas de doação em geral, restará caracterizado o inadimplemento antecipado sempre que o promitente-doador declarar antecipadamente que não irá adimplir ou adotar um comportamento incompatível com o adimplemento.

Verifica-se, assim, que não há impedimento à caracterização de inadimplemento antecipado nos contratos unilaterais, haja vista que o fundamento e o substrato jurídico-axiológico dessa figura não são o sinalagma e a cláusula resolutória tácita, mas sim a proteção da boa-fé, a confiança e a legítima expectativa, que deverão ser tuteladas em qualquer contrato, independentemente da sua classificação ou natureza.

\footnotetext{
${ }^{590}$ AZEVEDO, Fábio de Oliveira. Algumas questões de direito civil e de direito processual civil sobre o contrato preliminar. In: HIRONAKA, Giselda Maria Fernandes Novaes Hironaka; TARTUCE, Flávio (Coord.). Direito contratual. Temas Atuais. São Paulo: Método. 2007. p. 408-409.
} 


\subsubsection{Contratos Relacionais}

Conforme se exporá a seguir, a figura do inadimplemento antecipado se aplica com ainda mais intensidade nos chamados contratos relacionais. Antes disso, todavia, é necessário tecer breves comentários acerca da teoria relacional, que representa uma importante tentativa de renovação da dogmática contratual clássica ${ }^{591}$.

De início, deve ser feita uma associação entre o direito contratual e as estruturas da organização da indústria, da produção e mercado de trocas em um determinado contexto histórico $^{592}$. Neste sentido, por exemplo, o modelo contratual clássico, que tem "como características básicas o fato de [os contratos] serem impessoais, 'presentificadores' ('presentacional'), envolverem uma barganha entre partes instrumentalmente orientadas e requererem o mútuo consentimento das partes" ${ }^{\text {"593 }}$, se alinhou ao modelo econômico dos séculos XVIII e XIX, em que se visava fundamentalmente transações de troca de mercadorias a curto prazo.

Ocorre que, no cenário atual, em que os agentes econômicos cada vez mais celebram contratos associativos para viabilizar a prática de uma atividade econômica e atingir o fim comum por eles buscado, um modelo teórico baseado na contraposição de interesses e em contratos de execução imediata ou de curto prazo se demonstra insuficiente para estimular o fluxo das relações econômicas.

Foi essa constatação que impôs a necessidade de um novo modelo contratual capaz de justificar um cenário fático em que os contratos tendem a ser celebrados por um longo prazo e trazem processos de cooperação interempresariais, modelos de

\footnotetext{
${ }^{591}$ Destaque-se que o objetivo do presente estudo não é esgotar a análise do tema dos contratos relacionais, mas apenas destacar alguns aspectos relevantes para o exame do inadimplemento antecipado. Para um estudo aprofundado, recomenda-se: MACEDO JÚNIOR, Ronaldo Porto. Contratos relacionais e defesa do consumidor. São Paulo: Max Limonad. 1998.

${ }_{592}$ MACEDO JÚNIOR, Ronaldo Porto. Contratos relacionais e defesa do consumidor. São Paulo: Max Limonad. 1998. p. 99.

593 MACEDO JÚNIOR, Ronaldo Porto. Contratos relacionais e defesa do consumidor. São Paulo: Max Limonad. 1998. p. 106.
} 
comportamentos a serem adotados pelos agentes econômicos. Daí ser criada a figura teórica dos contratos relacionais, definidos por Orlando Gomes da seguinte forma:

\begin{abstract}
[...] pode-se afirmar que o contrato relacional tem por características principais a longa duração e a exigência de forte colaboração entre as partes. São relacionais, assim, todos os contratos que, sendo de duração, têm por objeto a colaboração (contratos de sociedade, parcerias, consórcios interempresariais etc.), e, ainda, os que, mesmo não tendo por objeto a colaboração, exigem-na intensa para poder atingir os seus fins, como os contratos de distribuição e franquia. ${ }^{594}$
\end{abstract}

Em linhas gerais, os contratos relacionais podem ser conceituados como aqueles que tendem a ser celebrados pelas partes por um longo prazo; são incompletos, visto que não é possível prever todos os acontecimentos futuros; e trazem processos de cooperação interempresariais e modelos de comportamentos a serem adotados pelos agentes econômicos. ${ }^{595}$.

Por exemplo, os contratos de planos de saúde, de seguros em geral, bancários, de uso de cartão de crédito, previdência privada, trabalhistas, cooperação tecnológica entre empresas, franquia, de transmissão de informações por cabo, de luz, água, telefone, etc., são típicos contratos relacionais.

Os contratos relacionais são contratos de longa duração que visam disciplinar a atuação conjunta de duas ou mais partes para um determinado fim e têm caráter fortemente associativo. Antonio Junqueira de Azevedo assevera que "são relacionais todos os contratos que, sendo de duração, têm por objeto colaboração (sociedade, parcerias, etc.) e, ainda, os que, mesmo não tendo por objeto a colaboração, exigem-na intensa para poder atingir os seus fins, como os de distribuição e franquia"596.

\footnotetext{
${ }^{594}$ GOMES, Orlando. Contratos. Rio de Janeiro: Forense. 2008. p. 99.

595 MACEDO JÚNIOR, Ronaldo Porto. Contratos relacionais no direito brasileiro. Disponível em: <http://www.edisin.com.br/i-ver-usp1.htm>. Acesso em: 10 jul. 2013. No mesmo sentido: "Esse tipo de contrato (p. ex contratos de franquia, de trabalho, de fornecimento entre empresas, contratos previdenciários e contratos bancários) caracteriza-se pela longa duração; pela mutabilidade constante; pelo alto grau de flexibilidade das situações reguladas; pela indeterminação dos termos das relações contratuais; e pelo caráter processual". FERES, Marcos Vinicius Chein; DIAS, João Paulo Torres. Teoria geral dos contratos relacionais: uma análise procedimental. Revista de Direito Privado, ano 8, n. 30, abril-jun 2007, p. 179.

${ }^{596}$ AZEVEDO, Antonio Junqueira. Estudos e Pareceres de Direito Privado. Saraiva, 2004. Natureza Jurídica do contrato de consórcio. Classificação dos atos jurídicos quanto ao número de partes e quanto aos efeitos.
} 
Em razão do caráter contínuo dos contratos relacionais e, dada a mutabilidade do mercado, da tecnologia e dos fenômenos sociais e a impossibilidade das partes regularem precisamente todos os termos da relação contratual, os contratos relacionais tendem a criar relações contínuas e duradouras nas quais os termos dos contratos são cada vez mais abertos, e as cláusulas substantivas são substituídas por cláusulas de regulamentação do processo de renegociação contínua para que a relação contratual possa responder a eventuais mudanças de circunstâncias de forma efetiva.

Com relação ao tema do caráter aberto e da necessidade da renegociação dos contratos relacionais, Ronaldo Porto Macedo Júnior pondera que:

[...] No caso dos contratos relacionais, ao contrário, o planejamento vai assumindo um caráter menos substantivo e mais processual ou constitucional, à medida que passa a regular a forma pela qual a revisão e reformulação do planejamento vai se operar. Neste caso, os termos contratuais passam a definir menos as regras para o fornecimento do produto ou do serviço, e mais as regras processuais que pela própria regulação sobre o fornecimento serão definidas. ${ }^{597}$

A doutrina moderna ressalta que os contratos relacionais envolvem relações complexas e duradouras entre diversas partes, nas quais os vínculos pessoais e de solidariedade, confiança e cooperação são imprescindíveis para que os contratos possam se adequar às mudanças sociais, econômicas e legais que podem ocorrer durante os vários anos de relação contratual. É o que salienta Ronaldo Porto Macedo Júnior:

Tanto a doutrina contratual neoclássica como o pensamento econômico liberal neoclássico fundamentam-se na premissa comum de que as pessoas no mercado agem racionalmente maximizando vantagens individuais. Uma ampla revisão de tais premissas têm sido feito tanto pela bibliografia econômica e sociológica no sentido de reavaliar a importância de relações de confiança, solidariedade e

Os contratos relacionais. Alteração das circunstâncias e onerosidade excessiva. Resolução parcial do contrato. Função social do contrato. RTDC, v. 21, jan/mar 2005, p. 252.

597 MACEDO JÚNIOR, Ronaldo Porto. Contratos relacionais e defesa do consumidor. São Paulo: Max Limonad. 1998. p. 163. Maria Luíza Pereira de Alencar Mayer Feitosa complementa que: “[...] Nos contratos relacionais projeta-se uma lógica diferente, determinada, em regra, pela análise econômica, pelo contingenciamento e pela flexibilidade, formando um continuum processual em cujo interior as partes (em geral, empresas comerciais) são instigadas à renegociação do acordo, ajustado e reajustado regularmente segundo as exigências internas, surgidas do processo econômico, de modo a não comprometer o funcionamento geral da rede de contratos (network contratual) que os agentes são levados a estruturar". FEITOSA, Maria Luíza Pereira de Alencar Mayer. As relações multiformes entre contrato e risco. Revista de Direito Mercantil, Industrial e Financeiro, v. 139. jul-set 2005, p. 115-116. 
cooperação [...]. Tais princípios tendem a se tornar cada vez mais importantes na medida em que os contratos se tornam mais relacionais. Neste sentido, os contratos relacionais aproximam-se mais do ideal de contrato de sociedade do que da compra e venda clássica. ${ }^{598}$

Para a teoria relacional, a boa-fé objetiva tem uma importante função na constituição, na execução e na extinção do contrato, porque imporá um comportamento correto e justo para partes durante toda a relação contratual, assegurando a proteção da confiança e solidariedade, elementos imprescindíveis nos contratos relacionais.

Com efeito, a própria natureza dos contratos relacionais, caracterizada pela necessidade de uma grande colaboração entre as partes ao longo da relação contratual e por uma forte indefinição na sua projeção para o futuro, tendo em vista o caráter aberto dos contratos relacionais, faz com que a aplicação da boa-fé objetiva seja ainda mais intensa nos contratos relacionais. É esse o entendimento de Antônio Junqueira de Azevedo a respeito da questão:

[...] no próprio grupo dos contratos empresariais, é preciso distinguir entre os relacionais - com o conceito já adaptado ao nosso direito, - os não relacionais. $\mathrm{O}$ princípio da boa-fé deve ser mais intensamente considerado nos primeiros, tendo em vista o seu caráter aberto, com forte indefinição na sua projeção para o futuro, impondo, para atingir os seus fins, muita lealdade entre as partes. ${ }^{599}$

O conceito de boa-fé vem, assim, ganhando cada vez mais importância no âmbito dos contratos relacionais, consistindo na principal norma de ligação dos princípios de cooperação, confiança e solidariedade no direito contratual moderno e permitindo pensar o comportamento adequado dos agentes contratuais nos mais diferentes contextos, de modo que a boa-fé funciona como uma verdadeira "norma de calibração" ${ }^{600}$ da teoria contratual relacional.

598 MACEDO JÚNIOR, Ronaldo Porto. Contratos relacionais no direito brasileiro. Disponível em: <http://www.edisin.com.br/i-ver-usp1.htm>. Acesso em: 10 jul. 2013. p. 9.

${ }^{599}$ AZEVEDO, Antonio Junqueira. Estudos e Pareceres de Direito Privado. São Paulo: Saraiva. 2004. Natureza Jurídica do contrato de consórcio. Classificação dos atos jurídicos quanto ao número de partes e quanto aos efeitos. Os contratos relacionais. Alteração das circunstâncias e onerosidade excessiva. Resolução parcial do contrato. Função social do contrato. RTDC, v. 21, jan/mar 2005, p. 253.

${ }^{600}$ FERRAZ JR, Tércio Sampaio. Teoria da norma jurídica, Rio de Janeiro: Editora Forense. 1978. 
A respeito do papel da boa-fé na teoria relacional, cumpre mencionar a seguinte ponderação de Ronaldo Porto Macedo Júnior:

\begin{abstract}
Os elementos que evidenciam a importância da boa-fé dentro da perspectiva relacional podem ser assim sintetizados. Em primeiro lugar, a boa-fé lembra a incompletude dos contratos, os limites da capacidade de previsão humana, os custos e ameaças à solidariedade e as barreiras insuperáveis para a comunicação perfeita e sem ruídos entre as partes. Em segundo lugar, ela enfatiza, valoriza e torna juridicamente protegido o elemento de confiança, sem o qual nenhum contrato pode operar. Em terceiro lugar, ela evidencia a natureza participatória do contrato, que envolve comunidades de significados e práticas sociais, linguagem, normas sociais e elementos de vinculação não promissórios. Por fim, a boa-fé realça o elemento moral das relações contratuais. A boa-fé contratual envolve uma concepção moral de fazer algo corretamente e, neste sentido, reporta-se a uma concepção de Justiça Social, a Justiça enquanto normalidade e equilíbrio. ${ }^{601}$
\end{abstract}

Em razão da aplicação mais intensa do princípio da boa-fé nos contratos relacionais, o comportamento das partes antes, durante e até mesmo depois do cumprimento da prestação devida passa a produzir efeitos jurídicos ainda mais intensos, a ensejar uma série de consequências jurídicas (por exemplo, a caracterização do inadimplemento antecipado, a responsabilidade pós-contratual, o dever de reparar, etc.).

Assim sendo, na medida em que o caráter aberto, associativo e incompleto dos contratos relacionais exige das partes um dever geral de colaboração ainda mais acentuado, a violação antecipada deste dever de colaboração poderá autorizar, com ainda mais força, o reconhecimento do inadimplemento antecipado dos contratos relacionais, fazendo surgir os efeitos daí decorrentes.

Para ilustrar, pode ser mencionado o contrato relacional de cooperação tecnológica celebrado entre duas empresas do ramo farmacêutico para o desenvolvimento de um novo remédio para o tratamento de uma doença rara. Na hipótese de uma das empresas verificar que a outra está lhe ocultando informações relevantes com relação aos progressos das suas pesquisas e testes, estará configurada a violação do dever de colaboração imposto pela boa-fé objetiva, a ensejar o inadimplemento antecipado do contrato.

${ }^{601}$ MACEDO JÚNIOR, Ronaldo Porto. Contratos relacionais no direito brasileiro. Disponível em: $<$ http://www.edisin.com.br/i-ver-usp1.htm>. Acesso em: 10 jul. 2013. p. 10-11. 
Nota-se, portanto, que a violação dos deveres de colaboração, lealdade, solidarismo, eticidade, transparência, etc., impostos pela boa-fé, caracterizará mais facilmente o inadimplemento antecipado dos contratos relacionais, o que é essencial diante do seu caráter aberto, associativo e incompleto.

\subsection{Limites para a aplicação do inadimplemento antecipado}

Embora o instituto do inadimplemento antecipado seja um importante mecanismo de tutela do credor, evitando-se que ele tenha que esperar até o termo do contrato para requerer a sua resolução por inadimplemento, a sua aplicação deve ocorrer com cautela, de maneira que nem todo comportamento do devedor seja apto a gerar a resolução do contrato por inadimplemento antecipado, preservando-se os contratos e a sua função social, conforme preconiza o princípio da conservação dos negócios jurídicos ${ }^{602}$.

Não basta qualquer manifestação de vontade ou comportamento contrário à intenção de adimplir, devendo-se, em qualquer caso, ponderar e balancear os interesses do credor e do devedor, as circunstâncias do caso e as consequências do reconhecimento do inadimplemento antecipado do contrato, a fim de se evitar a adoção de consequências excessivamente onerosas contra o devedor.

Uma leitura contemporânea da figura do inadimplemento antecipado - à luz da função social e dos princípios da solidariedade e eticidade - impõe ao juiz um exame cuidadoso das consequências econômicas, jurídicas e extrapatrimoniais da sua caracterização para o credor, o devedor e para terceiros. Deve-se ter em mente que um contrato está inserido em um contexto muito maior e que o reconhecimento de uma hipótese de inadimplemento antecipado poderá ter grandes impactos não só para as partes contratantes mas também para a sociedade.

${ }^{602}$ MARTINS. Guilherme Magalhães. Inadimplemento antecipado do contrato. Revista Trimestral de Direito Civil, Rio de Janeiro, v. 36, out/dez 2008, p. 85. 
A aplicação do instituto do inadimplemento antecipado deve ser feita de maneira ponderada para evitar um "risco sistêmico" de descumprimento ainda maior de contratos. Por exemplo, no caso da incorporadora imobiliária que está em atraso com relação à construção das unidades habitacionais, o reconhecimento do inadimplemento antecipado para um ou mais dos seus adquirentes - que poderá implicar na resolução do contrato, com a consequente devolução dos valores recebidos e pagamento de indenização por perdas e danos - poderá aumentar o risco da incorporadora efetivamente não entregar as unidades habitacionais para os demais adquirentes.

O instituto do inadimplemento antecipado do contrato também deve encontrar limites nas figuras do abuso do direito, da proibição ao comportamento contraditório (venire contra factum proprium), do adimplemento substancial e do princípio da conservação dos negócios jurídicos a fim de se evitar que qualquer declaração ou comportamento do devedor seja apto a caracterizar o inadimplemento antecipado do contrato.

O inadimplemento antecipado não pode ser utilizado como um instrumento de opressão à disposição do credor, que deverá agir conforme os limites impostos pelo fim econômico e social do seu direito, observar os parâmetros de boa-fé e dos bons costumes e agir pautado pela razoabilidade e proporcionalidade, sob pena de incorrer em abuso de direito. $\mathrm{O}$ instituto do inadimplemento antecipado deve ser aplicado levando em consideração os standards de conduta impostos pelo princípio da boa-fé objetiva, para não servir como um instrumento de pressão para os credores ${ }^{603}$.

A figura da quebra antecipada do contrato também não pode ser utilizada pelo credor como uma "válvula de escape para que, arrependido do contrato celebrado, aproveite-se de conduta duvidosa do devedor para, considerando-o inadimplente, livrar-se da indesejada relação contratual" ${ }^{104}$, o que caracteriza verdadeiro abuso de direito. O instituto deve ser utilizado para proteger o credor nas situações em que restem preenchidos

\footnotetext{
${ }^{603}$ MARTINS. Guilherme Magalhães. Inadimplemento antecipado do contrato. Revista Trimestral de Direito Civil, Rio de Janeiro, v. 36, out/dez 2008, p. 95.

${ }^{604}$ TERRA, Aline de Miranda Valverde. Inadimplemento anterior ao termo. Rio de Janeiro: Renovar. 2009. p. $159-160$.
} 
os seus requisitos fáticos autorizadores, e não como uma justificativa para o rompimento indevido de contratos.

A esse respeito, confira-se o posicionamento de Jelena Vilus ao comentar o artigo 72 da Convention on Contracts for the International Sales of Goods, que trata do inadimplemento antecipado dos contratos:

There are, however, other views according to which such a right may be dangerous since, even if there is a breach, this does not necessarily mean that the contract will not be fulfilled. It is not always easy to provide clear proof of a fundamental breach of contract except in exceptional cases, for instance, bankruptcy of the debtor. In other words, there is the possibility that abuse may arise, especially in cases where the creditor has the opportunity to conclude a contract with other partners under better conditions. ${ }^{605}$

Em qualquer das hipóteses caracterizadoras do inadimplemento antecipado, impõe-se avaliar se o suporte fático objetivo se refere à parte substancial ou ínfima da avença. À luz da teoria do adimplemento substancial, que estabelece um controle de legitimidade dos mecanismos de tutela do credor $^{606}$, entende-se que somente se caracterizará o inadimplemento antecipado quando se vislumbrar que parcela expressiva da prestação, vinculada diretamente ao interesse típico e concreto do credor naquela relação jurídica, não será cumprida na data avençada ${ }^{607}$.

${ }^{605}$ VILUS, JELENA. Provisions common to the obligations of the seller and the buyer. In: International Sale of Goods. Dubrovnik Lectures. Oceana Publications. 1986. p. 244-245. Em tradução livre: "Há, no entanto, outros pontos de vista, segundo o qual esse direito pode ser perigoso, já que, mesmo se houver uma violação, isso não significa necessariamente que o contrato não será cumprido. Nem sempre é fácil fazer prova clara de uma violação fundamental do contrato a não ser em casos excepcionais, por exemplo, a falência do devedor. Em outas palavras, existe a possibilidade de que o abuso pode surgir, especialmente nos casos em que o credor tem a oportunidade de celebrar um contrato com outros parceiros em melhores condições."

606 SCHREIBER, Anderson. A tríplice transformação do adimplemento. Adimplemento substancial, inadimplemento antecipado e outras figuras. Revista Trimestral de Direito Civil, Rio de Janeiro, v. 32, out./dez 2007, p. 21-23.

${ }^{607}$ Nesse sentido, confira-se o posicionamento de Anderson Schreiber: "O atual desafio da doutrina está em fixar parâmetros que permitam ao Poder Judiciário dizer, em cada caso, se o adimplemento afigura-se ou não significativo ou, substancial. [...]

Do exame da doutrina e da jurisprudência comparada podem-se extrair alguns parâmetros que, sem a pretensão de encerrar o debate, têm sido apontados como índices capazes de sugerir a configuração do adimplemento substancial, auxiliando o juiz em seu ofício. Para além da usual comparação entre o valor do bem ou do contrato e de outros índices que possam sugerir 'a manutenção do equilíbrio entre as prestações correspectivas, não chegando o descumprimento parcial a abalar o sinalagma', a tendência tem sido, hoje, de perquirir, em cada caso concreto, a existência de outros remédios capazes de atender ao interesse do credor (e.g., perdas e danos), com efeitos menos gravosos ao devedor - e a eventuais terceiros afetados pela relação obrigacional que a resolução". SCHREIBER, Anderson. A Boa-fé objetiva e o Adimplemento Substancial. 
Essa avaliação tem lugar normalmente quando a declaração de não cumprir ou a impossibilidade da prestação se refere a apenas parcela do contrato, e não a toda a prestação devida. É o caso, por exemplo, da incorporadora que envia comunicado às pessoas que adquiriram unidades habitacionais de um condomínio de prédios informando que certas atrações da área de lazer - como, por exemplo, a churrasqueira e o playground não serão entregues junto com as unidades na data avençada, mas sim com alguns meses de atraso. Nesse caso, não poderá ser admitida a caracterização de hipótese de inadimplemento antecipado, com a aplicação de todos os seus efeitos, cabendo somente uma indenização.

Outro exemplo é a situação em que "B" foi contratado por "A" para construir uma casa que o arquiteto "O" projetou. Durante a construção, "B" informa a "A" que o tipo de janela de vidro especificada no projeto de "O" não está mais disponível no mercado, mas que ele encontrou uma janela bastante semelhante, mas não idêntica. $\mathrm{O}$ descumprimento da obrigação de instalar uma janela de vidro idêntica à constante no projeto de "O" não poderá ensejar o inadimplemento antecipado do contrato celebrado entre "A" e "B" à luz da teoria do inadimplemento substancial.

O inadimplemento antecipado também não é aplicável em casos nos quais a suposta violação atinge apenas deveres laterais pouco significativos, mantendo-se intacto o núcleo obrigacional e subsistindo a possibilidade de cumprimento da obrigação pelo devedor e a utilidade da prestação para o credor. Trata-se de outro caso de aplicação da teoria do adimplemento substancial. É plenamente possível, portanto, que venha a ocorrer o descumprimento de deveres anexos sem que se configure o inadimplemento antecipado $^{608}$.

É o que explica Jorge Cesa Ferreira da Silva: “[...] o caso do descumprimento de deveres laterais pouco significativos ou da concretização de danos extrapatrimoniais

In: HIRONAKA, Giselda Maria Fernandes Novaes; TARTUCE, Flávio (Coord.), Direito Contratual. Temas Atuais. São Paulo: Método. 2007. p. 139-141.

${ }^{608}$ ANDRADE, Luis Tomás Alves de. O Inadimplemento Antecipado do Contrato no Direito Brasileiro. $R$. EMERJ, Rio de Janeiro, v. 14, n. 56, p. 145-172, out-dez. 2011, p. 159. 
vinculados ao contrato, mas não inviabilizadores da prestação futura"609. Nesses casos, também fica ressalvado ao credor o direito de ser indenizado ou ressarcido pelo descumprimento do dever anexo ${ }^{610}$.

A teoria do adimplemento substancial deverá impedir, assim, a caracterização da quebra antecipada do contrato quando não se vislumbrar um inadimplemento de parcela substancial da prestação devida, assim como no âmbito do direito estrangeiro e internacional somente se admite a aplicação dos remédios típicos do inadimplemento quando houver o descumprimento de obrigação fundamental ("fundamental nonperformance" $)^{611}$.

Acrescente-se que é necessário realizar uma ponderação entre o momento em que a relação obrigacional se encontra e as consequências do reconhecimento do inadimplemento antecipado para as partes contratantes, pois, dependendo do estágio de cumprimento da obrigação, o instituto da quebra antecipada pode ser inaplicável. Isso ocorre, por exemplo, quando o devedor já cumpriu parcela substancial da avença, de modo que a aplicação do instituto e das suas consequências jurídicas acabaria por gerar mais prejuízos para as partes do que efetivamente evita-los. ${ }^{612}$ Trata-se de um caso em que a

609 SILVA, Jorge Cesa Ferreira da. A boa-fé e a violação positiva do contrato. Rio de Janeiro: Renovar. 2002. p. 259.

${ }^{610}$ Conforme adverte Luis Tomás de Andrade, é importante destacar que a violação de deveres anexos somente não caracteriza inadimplemento antecipado quando "isso ocorre em relação aos deveres laterais pouco expressivos, em relação aos quais não se mostraria razoável a imputação do inadimplemento antecipado, uma vez que o núcleo do contrato ainda se manteria executável". O descumprimento de deveres laterais expressivos e que interfiram diretamente sobre a prestação devida e a satisfação do interesse do credor, por óbvio, admite a invocação do inadimplemento antecipado. ANDRADE, Luis Tomás Alves de. O Inadimplemento Antecipado do Contrato no Direito Brasileiro. R. EMERJ, Rio de Janeiro, v. 14, n. 56, p. 145-172, out-dez. 2011, p. 160.

${ }^{611}$ A título de exemplo é possível mencionar o artigo 72 da Convention on Contracts for the International Sales of Goods, o artigo 7.3.3 dos princípios UNIDROIT relativos aos Contratos Comerciais Internacionais e o artigo 504 do Draft Common Frame of Reference (DCFR). Nos seus comentários ao art. 72 da Convention on Contracts for the International Sales of Goods, Schlechtriem \& Schwenzer afirmam que "a violação futura deve ser de uma natureza tão substancial, a ponto de privar o credor do que ele tinha direito de esperar, de acordo com o contrato". SCHLECHTRIEM, Peter; SCHWENZER, Ingeborg. Comentários à Convenção das Nações Unidas sobre Contratos de Compra e Venda Internacional de Mercadorias. Coordenação de tradução de GREBER, Eduardo; FRADERA, Vera; PEREIRA, César Guimarães. São Paulo: Editora Revista dos Tribunais. 2014. p. 1.080 .

612 ANDRADE, Luis Tomás Alves de. O Inadimplemento Antecipado do Contrato no Direito Brasileiro. R. EMERJ, Rio de Janeiro, v. 14, n. 56, p. 145-172, out-dez. 2011. p. 159. 
caracterização do inadimplemento antecipado encontra limite na função restritiva da boa-fé objetiva.

A esse respeito, Anelise Becker afirma que o inadimplemento antecipado não pode ser aplicado "quando a realização da prestação a cargo do devedor, já foi iniciada e se encontra de tal como completa que seria impraticável estimar os danos por ele sofridos; ou quando terminar os trabalhos diminuiria os danos do proprietário da obra ou, pelo menos, não os agravaria" ${ }^{\prime 613}$. Em tais circunstâncias, em que o reconhecimento do inadimplemento antecipado traria maiores prejuízos paras as partes, não poderão ser aplicados todos os seus efeitos, de maneira que o contrato não poderá ser resolvido e o credor deverá continuar a cumprir a obrigação que lhe incumbe. Fica ressalvado, todavia, o direito do credor ser indenizado ou ressarcido pelo cumprimento defeituoso ou atraso da prestação.

Nas hipóteses de caso fortuito e força maior, também se deixa de aplicar a teoria do inadimplemento antecipado tendo em vista o rompimento do nexo de causalidade da responsabilidade do devedor pelos danos sofridos pelo credor em decorrência do inadimplemento. Trata-se da aplicação do artigo 393 do Código Civil, segundo o qual "o devedor não responde pelos prejuízos resultantes de caso fortuito ou força maior, se expressamente não se houver por eles responsabilizado".

É assim que se posiciona Raphael Manhães Martins, que afirma que o inadimplemento antecipado não se configurará quando o devedor estiver diante de caso fortuito ou força maior ${ }^{614}$. Aliás, isso nem poderia se dar de outra forma, uma vez que, nessas hipóteses, o inadimplemento antecipado estaria ligado a fatores absolutamente alheios à vontade do devedor, razão pela qual não se mostraria justa a imputação de responsabilidade pelo não cumprimento do contrato.

No entanto, Raphael Manhães Martins corretamente observa que, mesmo diante de uma impossibilidade decorrente de caso fortuito ou força maior, poderá restar

\footnotetext{
${ }^{613}$ BECKER, Anelise. Inadimplemento antecipado do contrato. Revista de Direito do Consumidor, São Paulo: Revista dos Tribunais, n. 12, 1994. p. 74.

${ }^{614}$ MARTINS, Raphael Manhães. Inadimplemento antecipado: perspectiva para a sua aplicação no Direito brasileiro. Revista Forense, Rio de Janeiro, v. 391, ano 103, mai./jun. 2007, p. 214.
} 
caracterizado o inadimplemento antecipado se as partes tiverem expressamente assumido esse risco no contrato, conforme autoriza a parte final do artigo 393 do Código Civil. A esse respeito, o autor pondera que:

\begin{abstract}
Da mesma forma, ainda que ocorra uma situação de impossibilidade, se esta decorrer de caso fortuito ou força maior, não será possível considerar como um inadimplemento antecipado, por força do disposto no art. 393 do CC. Isso, é claro, salvo se o risco por uma dessas situações tenha sido assumido pela parte. Nestes casos, mesmo tendo se materializado o risco de caso fortuito ou força maior, será possível a aplicação do inadimplemento antecipado quando implicar a impossibilidade de cumprir, ou mesmo pelo fato de a parte recusar-se a cumprir, diante da ocorrência de uma dessas situações. ${ }^{615}$
\end{abstract}

Também não há que se falar em configuração de inadimplemento antecipado caso se esteja diante de uma hipótese de excessiva onerosidade superveniente (disciplinada nos artigos 478 a 480 do Código Civil ${ }^{616}$ ). Caso o devedor esteja impedido de realizar os atos preparatórios, os atos de execução, os deveres de conduta ou dos deveres anexos em decorrência de uma situação de onerosidade excessiva superveniente, a qual torna extremamente custoso o cumprimento da prestação devida, entende-se que o credor estará impossibilitado de invocar a teoria do inadimplemento antecipado ${ }^{617}$.

\footnotetext{
${ }^{615}$ MARTINS, Raphael Manhães. Inadimplemento antecipado: perspectiva para a sua aplicação no Direito brasileiro. Revista Forense, Rio de Janeiro, v. 391, ano 103, mai./jun. 2007, p. 214.

616 "Art. 478. Nos contratos de execução continuada ou diferida, se a prestação de uma das partes se tornar excessivamente onerosa, com extrema vantagem para a outra, em virtude de acontecimentos extraordinários e imprevisíveis, poderá o devedor pedir a resolução do contrato. Os efeitos da sentença que a decretar retroagirão à data da citação.”

"Art. 479. A resolução poderá ser evitada, oferecendo-se o réu a modificar eqüitativamente as condições do contrato."

"Art. 480. Se no contrato as obrigações couberem a apenas uma das partes, poderá ela pleitear que a sua prestação seja reduzida, ou alterado o modo de executá-la, a fim de evitar a onerosidade excessiva."

617 Vale mencionar o posicionamento de Ruy Rosado Aguiar Júnior sobre a onerosidade excessiva superveniente: "A onerosidade excessiva é, na verdade, um caso de inexigibilidade de conduta, pois o devedor age voluntariamente contra o dever derivado do contrato, mas o faz em razão dos fatos extraordinários modificativos. Não se trata propriamente de uma exceção, arguida contra a ação de adimplemento, mas de uma defesa direta, que nega definitivamente a possibilidade de o credor deduzir sua pretensão em juízo. Se o credor preferir a ação de resolução, com base no incumprimento do devedor, a defesa deste, fundada na onerosidade excessiva, será igualmente a negação do direito formativo do credor, o que lhe valerá para liberação da responsabilidade pelas perdas e danos, uma vez que tal ação de resolução será julgada parcialmente procedente, pois evidenciado o incumprimento, apenas que justificado pela onerosidade excessiva." AGUIAR JÚNIOR, Ruy Rosado de. Extinção dos contratos por incumprimento do devedor. 2. ed. Rio de Janeiro: AIDE. 1991. p. 158-159.
} 
Isso porque a onerosidade excessiva superveniente ${ }^{618}$ pressupõe um desequilíbrio contratual posterior ao momento da celebração do contrato que tenha sido causado por fatos imprevisíveis e extraordinários (e, obviamente, não provocados pelo próprio devedor $)^{619}$. Assim, como a onerosidade excessiva superveniente decorre de um fato não imputável ao devedor, entendemos que, nesse caso, não está satisfeito o suporte fático para o credor requerer a aplicação do instituto do inadimplemento antecipado. $\mathrm{O}$ devedor não teve uma conduta que o faça perder o benefício do termo contratual.

Ressalte-se que a onerosidade excessiva superveniente apenas impede a caracterização do inadimplemento antecipado se o devedor (i) não estiver em mora quando do acontecimento do fato imprevisível e extraordinário; e (ii) tiver adotado um padrão de comportamento compatível com o princípio da boa-fé objetiva, tomando as medidas possíveis e recomendadas para o cumprimento do contrato mesmo diante da iminência ou da ocorrência do fato imprevisível ou extraordinário ${ }^{620}$.

\footnotetext{
${ }^{618}$ Para se caracterizar uma hipótese de onerosidade excessiva superveniente, é necessário que incorram requisitos de apuração certa, explicitados no artigo 478 do Código Civil: (i) vigência de um contrato de execução diferida ou continuada; (ii) alteração radical das condições econômicas objetivas no momento da execução, em confronto com o ambiente objetivo da celebração; (iii) onerosidade excessiva para um dos contratantes e benefício exagerado para o outro; e (iv) imprevisibilidade daquela modificação. PEREIRA, Caio Mário da Silva. Instituições de Direito Civil. 12. ed. Rio de Janeiro: Forense. 2005. v. 3. p. 166.

${ }^{619}$ Confiram-se os ensinamentos de Serpa Lopes a respeito: "A imprevisão consiste no desequilíbrio das prestações recíprocas, nos contratos de prestações recíprocas ou deferidas, em conseqüência de acontecimentos ulteriores à formação do contrato, independentemente da vontade das partes, de tal forma extraordinários e anormais que impossível se torna prevê-los razoável e antecedentemente. São acontecimentos supervenientes que alteram profundamente a economia do contrato, por tal forma perturbando o seu equilíbrio, como inicialmente estava fixado, que se torna certo que as partes jamais contratariam de pudessem ter podido antever os fatos. Se, em tais circunstâncias, o contrato fosse mantido, redundaria num enriquecimento anormal, em benefício do credor, determinando um empobrecimento da mesma natureza, em relação ao devedor. Conseqüentemente, a imprevisão tende a alterar ou excluir a força obrigatória do contrato.” SERPA LOPES, Miguel Maria de. Curso de direito civil. Atualização de José Serpa Santa Maria. 4. ed. rev. e atual. Rio de Janeiro: Freitas Bastos. 1991. v.3. p. 100.

${ }^{620}$ São essas as lições de Ruy Rosado Aguiar Júnior: "Se a parte já estiver em mora, quando dos fatos extraordinários, não lhe cabe a defesa. $\mathrm{O}$ devedor em mora responde pelos riscos supervenientes, ainda que decorrentes de caso fortuito ou força maior (art. 957, Código Civil). A onerosidade é um aspecto da teoria da superveniência, e nela se afirma o princípio da responsabilidade do devedor moroso pela impossibilidade posterior.

O contratante pode arguir a onerosidade excessiva como defesa, ou em reconvenção, na ação de adimplemento ou na de resolução. Deverá sua alegação ser apreciada à luz da boa-fé, pois o comportamento do devedor, que, p. ex., ainda no prazo para efetivar a prestação deixa de tomar as medidas possíveis e recomendadas para o cumprimento do contrato, uma vez evidenciada a iminência de fatos futuros e extraordinários determinantes da onerosidade, demonstra comportamento contrário aos deveres secundários de conduta." AGUIAR JÚNIOR, Ruy Rosado de. Extinção dos contratos por incumprimento do devedor. 2. ed. Rio de Janeiro: AIDE. 1991. p.156.
} 
Por fim, vale acrescentar que, da mesma forma como não se considera inadimplido o contrato nos casos em que o incumprimento da obrigação não pode ser imputável ao devedor, não se configura o inadimplemento antecipado diante de situações de não imputação dos efeitos do inadimplemento. Nesse sentido, não será possível considerar inadimplido antecipadamente um contrato quando o devedor possuir fundada e legítima justificativa para não realizar atos preparatórios e atos de execução, ou seja, não cumprir o que fora previamente acordado entre as partes ${ }^{621}$.

Como exemplos de casos em que o devedor tem fundada e legítima justificativa para não cumprir a prestação devida também podem ser citados os casos em que: (i) as especificações do contrato não permitem a sua execução (por exemplo, por erro no projeto ou falta de dados, que deveriam ser fornecidos pelo contratante); (ii) são necessárias autorizações e/ou licenças governamentais para continuar executando a obra, as quais são de responsabilidade da outra parte; (iii) entende-se, justificadamente, necessário obter esclarecimentos da contratante, que se recusa ou demora em fornecê-los; (iv) o contratante impõe mudanças substanciais no projeto original de uma obra, sem que haja previsão para tanto no contrato; ou (v) o próprio credor viola um dever de cooperação, decorrente de boa-fé, quando esta cooperação for necessária à realização de sua pretensão $^{622}$.

Em todas as situações mencionadas acima, independentemente do critério de imputação da responsabilidade contratual (objetivo ou subjetivo), o credor não poderá invocar o inadimplemento antecipado porque não há um nexo de causalidade entre o comportamento do devedor e a situação de inadimplemento. É importante verificar, portanto, qual foi a causa da situação de inadimplemento para verificar se ele pode ser imputado ao devedor e, por via de consequência, se o credor poderá requerer o inadimplemento antecipado e a aplicação de todos os seus efeitos em face do devedor.

\footnotetext{
${ }^{621}$ MARTINS, Raphael Manhães. Inadimplemento antecipado: perspectiva para a sua aplicação no Direito brasileiro. Revista Forense, Rio de Janeiro, v. 391, ano 103, mai./jun. 2007, p. 213.

${ }^{622}$ Os exemplos são de MARTINS, Raphael Manhães. Inadimplemento antecipado: perspectiva para a sua aplicação no Direito brasileiro. Revista Forense, Rio de Janeiro, v. 391, ano 103, mai./jun. 2007, p. 214.
} 


\subsection{Inadimplemento antecipado do contrato imputável ao credor}

Como abordado no primeiro capítulo, todas as transformações que a boa-fé objetiva promoveu no campo do direito das obrigações também alteraram profundamente o papel do credor na relação obrigacional. A noção da "obrigação como processo" passou a exigir a cooperação do credor, seja por meio de um comportamento ativo, ou passivo, para viabilizar o adimplemento contratual e a satisfação do interesse das partes.

Partindo dessa premissa, é importante mencionar que a ausência de colaboração do credor no programa obrigacional - seja com relação a deveres principais, secundários ou laterais - pode consistir na principal (em alguns casos, a única) causa do inadimplemento antecipado do contrato.

Imagine-se o caso em que as partes pactuam a construção de uma determinada obra em etapas, sendo que "A" só poderá iniciar a construção da etapa seguinte se "B" aprovar a etapa anterior, mas. "B" se omite ou se recusa injustificadamente a aprovar a etapa anterior. Outro exemplo é o caso em que uma pessoa contrata uma costureira para confeccionar o seu vestido de casamento, mas não comparece nas datas combinadas para prová-lo e fazer os ajustes necessários. Pode-se mencionar também a situação em que o contratante não consegue obter as licenças e autorizações necessárias para a construção de uma fábrica.

Nessas situações em que a recusa ou a impossibilidade do devedor em cumprir a sua obrigação no termo pactuado decorre de um comportamento, culposo ou não, do credor, não há que se falar em mora debitoris, inadimplemento absoluto ou inadimplemento antecipado imputável ao devedor ${ }^{623}$. Logo, o credor não poderá se valer da

${ }^{623}$ RAMELLA, Anteo E. La resolución por incumplimiento. Buenos Aires: Editoral Astrea. 1975. p. 67. 
ação resolutória, da demanda de cumprimento (execução específica) ou pleitear perdas e danos em face do devedor ${ }^{624}$.

Com efeito, é possível aplicar aos casos descritos acima a exceção de contrato não cumprido (exceptio non adimpleti contractus) ${ }^{625}$, prevista no artigo 476 do Código Civil, segundo a qual, "nos contratos bilaterais, nenhum dos contratantes, antes de cumprida a sua obrigação, pode exigir o implemento da do outro".

De acordo com o referido dispositivo legal, nos contratos bilaterais, se uma parte estiver previamente inadimplente em relação às suas obrigações, ela não poderá invocar o inadimplemento do contrato pela recusa da outra em adimplir ${ }^{626}$. A exceção de contrato não cumprido é, pois, "uma causa impeditiva da exigibilidade da prestação por parte daquele que não efetuou a sua, franqueando ao outro uma atitude de expectativa, enquanto aguarda a execução normal do contrato" ${ }^{27}$.

\footnotetext{
${ }^{624}$ Sobre a questão, Ruy Rosado Aguiar Júnior afirma que o credor tem "o dever secundário de colaborar para a plena realização do contrato. Descumprindo-o, com ou sem culpa, impossibilitando a prestação ou recusando a oferta, incorre o credor em mora, o que afasta a do devedor e deixa sem fundamento o seu pedido de resolução". Todavia, o autor observa que "o credor que deixou de cumprir parte insignificante da prestação, cuja falta não justificava o incumprimento da contraparte, não fica privado do direito de resolução. O que entregou o prédio locado, sem pintura prometida, cometeu uma falta, mas pode resolver, se não receber os alugueis, porque a falha do locatário é mais grave, já que está usando o bem. Cuida-se de verificar a prevalência de um adimplemento sobre o outro, atendendo à realidade total do contrato, com os dados objetivos (equivalência entre as prestações) e subjetivos (finalidade e condições pessoais das partes), de acordo com a boa fé". AGUIAR JÚNIOR, Ruy Rosado. Extinção dos contratos por incumprimento do devedor. 2. Ed. Rio de Janeiro: AIDE, 1991. p.166-167.

625 Caio Mário da Silva Pereira afirma que "o contrato bilateral caracteriza-se pela reciprocidade das prestações. Cada uma das partes deve e é credora, simultaneamente. Por isto mesmo, nenhuma delas, sem ter cumprido o que lhe cabe, pode exigir que a outra o faça. A idéia predominante aqui é a da interdependência das prestações (De Page). Daí se origina uma defesa oponível pelo contratante demandado, contra o cocontratante inadimplente, denominada exceptio adimpleti contractus, segundo a qual o demandado recusa a sua prestação, sob o fundamento de não ter aquele que reclama dado o cumprimento à que lhe cabe (Código Civil, art. 476)". PEREIRA, Caio Mario da Silva. Instituições de direito civil. v. III. Rio de Janeiro: Forense. 2006. p. 159.

${ }^{626}$ Sobre o tema, Orlando Gomes afirma que "nos contratos bilaterais, nenhum dos contratantes pode, antes de cumprida sua obrigação, exigir a do outro. Nessa hipótese, tem direito a invocar a exceção de contrato não cumprido. O fundamento desse direito é intuitivo. Visto que a essência dos contratos bilaterais é o sinalagma, isto é, a dependência recíproca de obrigações, nada mais conseqüente que cada qual das partes se recuse a executar o acordo, opondo a exceptio non adimplenti contractus. Se não cumpre a obrigação contraída, dado lhe é não exigir do outro contratante que cumpra a sua". GOMES, Orlando. Contratos. Rio de Janeiro: Forense. 2008. p. 109.

${ }^{627}$ PEREIRA, Caio Mario da Silva. Instituições de direito civil. v. III. Rio de Janeiro: Forense. 2006. p. 159.
} 
No mesmo sentido, o artigo 7.1.2 dos princípios UNIDROIT relativos aos Contratos Comerciais Internacionais estabelece que "uma parte não pode valer-se do inadimplemento da parte contrária na medida em que tal inadimplemento tenha sido provocado por ação ou omissão própria ou por outro evento por cuja superveniência tenha se responsabilizado". Em comentários ao referido artigo, João Baptista Villela afirma que "quando o artigo é aplicável, [...] a contraparte não terá direito à extinção do contrato por inadimplemento" ${ }^{628}$.

Desta feita, aplicando-se a exceção de contrato não cumprido (exceptio non adimpleti contractus) prevista no artigo 476 do Código Civil, entende-se que o credor que previamente descumpriu um dever obrigacional (que abrange deveres principais, secundários e anexos), não poderá invocar o inadimplemento antecipado e os seus efeitos $^{629}$.

Todavia, a nosso ver, um grave descumprimento, pelo credor, do dever de cooperação, não se restringe à aplicação da exceção de contrato não cumprido, facultando ao devedor o uso de remédios jurídicos como a consignação em pagamento ou até mesmo a resolução do contrato. Conforme sustentamos no primeiro capítulo, se o credor descumpre o seu dever de cooperar com o programa obrigacional, inclusive quanto aos deveres laterais, verifica-se uma situação de mora accipiendi; por sua vez, se esse descumprimento tornar impossível ou extremamente oneroso, por parte do devedor, a entrega da prestação devida, terá havido inadimplemento absoluto por fato imputável ao credor.

Aplicando essas conclusões para o tema do inadimplemento antecipado, podemos afirmar que, se o credor descumprir o seu dever de cooperar, provocando um

\footnotetext{
628 VILLELA, João Baptista et al. Princípios UNIDROIT relativos aos Contratos Comerciais Internacionais/2004 [versão em língua portuguesa]. São Paulo: Quartier Latin. 2009. p. 206.

629 VILLELA, João Baptista et al. Princípios UNIDROIT relativos aos Contratos Comerciais Internacionais/2004 [versão em língua portuguesa]. São Paulo: Quartier Latin. 2009. p. 207. No mesmo sentido: "o devedor, acionado por resolução, pode alegar que o credor autor não cumpriu com a sua contraprestação. Se o autor da ação é o único inadimplente, não há discutir: a ação improcede. Se ambas as partes não cumpriram, estão em mora o que deveria cumprir antes." AGUIAR JÚNIOR, Ruy Rosado de. Extinção dos contratos por incumprimento do devedor. 2. Ed. Rio de Janeiro: AIDE. 1991. p.166-167.
} 
inadimplemento antecipado, isso poderá acarretar (i) uma situação de mora accipiendi, se o adimplemento ainda for possível e útil, na qual o devedor permanecerá vinculado ao cumprimento da obrigação, mas incidirão os efeitos da mora do credor previstos no artigo 400 do Código Civil ${ }^{630}$; ou (ii) uma situação de inadimplemento absoluto por fato imputável ao credor, se o adimplemento for impossível ou inútil, excluindo-se a responsabilidade do devedor nos moldes do artigo 393 do Código Civil, e liberando-o do vínculo obrigacional.

Nesses casos, para que o devedor não fique eternamente vinculado à uma relação obrigacional cuja situação de inadimplemento antecipado ele não deu causa, ele poderá ajuizar uma demanda de cumprimento ou uma ação de resolução contra o credor, a depender do caso concreto, sendo sempre cabível o pedido de indenização por perdas e danos.

Sendo uma hipótese de mora accipiendi, em que a sua prestação pode estar eventualmente a depender da ação do credor, o devedor poderá ajuizar uma demanda de cumprimento, com fundamento nos artigos 461 e 461-A do Código de Processo Civil, pois não é exigível que fique o devedor indefinidamente à espera do credor. Por sua vez, caso esteja caracterizada uma situação de inadimplemento absoluto por fato imputável ao credor, o devedor poderá propor uma ação de resolução, para se desligar do contrato ${ }^{631}$.

Este também é o posicionamento de Ruy Rosado Aguiar Júnior a respeito do tema, conforme se verifica abaixo:

\begin{abstract}
Demonstrando o devedor da obrigação principal que a deixou de prestar pelo incumprimento do credor, poderá liberar-se do contrato através de ação resolutiva, desde que a falha o tenha impossibilitado ou tornado especialmente gravoso o cumprimento da prestação que lhe incumbia. Do mesmo modo, e pelos mesmos critérios com que se avalia o descumprimento do devedor, assim também, mutatis mutandis, examina-se o comportamento do credor. [...] Se a
\end{abstract}

\footnotetext{
630 "Art. 400. A mora do credor subtrai o devedor isento de dolo à responsabilidade pela conservação da coisa, obriga o credor a ressarcir as despesas empregadas em conservá-la, e sujeita-o a recebê-la pela estimação mais favorável ao devedor, se o seu valor oscilar entre o dia estabelecido para o pagamento e o da sua efetivação".

${ }^{631}$ No terceiro capítulo da presente dissertação serão analisados os aspectos gerais da ação de resolução e da demanda de cumprimento.
} 
parte que está disposta ao cumprimento do contrato não tem ação para exigir o comportamento favorável do credor tem, irrecusavelmente, o direito de desfazer a relação inviabilizada pelo credor. ${ }^{632}$

Essa análise sobre as consequências do descumprimento, pelo credor, do dever de colaboração é essencial no estudo do inadimplemento antecipado do contrato, pois permite concluir que o devedor não restará prejudicado na hipótese de o credor se omitir em seu dever de cooperar e acarretar uma situação de quebra antecipada.

\subsection{Há obrigatoriedade de se invocar o inadimplemento antecipado?}

O reconhecimento de que o inadimplemento anterior ao termo se fundamenta no inadimplemento da prestação devida permite, como será abordado no próximo capítulo, atribuir-lhe todos os efeitos das categorias clássicas de inadimplemento (mora e inadimplemento antecipado) - perdas e danos, resolução do contrato e, inclusive, a execução específica -, que podem ser produzidos imediatamente em virtude da perda do benefício do termo pelo devedor.

Assim, se por um lado, a doutrina moderna admite que é um direito do credor invocar a caracterização do inadimplemento antecipado quando satisfeitos os seus requisitos, é de se indagar se o credor também tem o dever de agir diante da recusa antecipada do devedor em adimplir, mitigando os seus danos, ou se ele pode quedar-se inerte aguardando o advento do termo contratual para, daí sim, tomar as medidas necessárias.

Para responder a essa indagação faz-se necessário examinar brevemente a doutrina inglesa da "mitigation of losses". De acordo com juristas ingleses, o credor que se sentir lesado por algum comportamento do devedor terá o dever legal ${ }^{633}$ de agir de modo a

${ }^{632}$ AGUIAR JÚNIOR, Ruy Rosado de. Extinção dos contratos por incumprimento do devedor. 2. ed. Rio de Janeiro: AIDE. 1991. p.163-164.

${ }^{633}$ Daniel Pires Novais Dias adverte que "o duty to mitigate the loss não corresponde a um dever (do credor de mitigar a própria perda). A expressão em inglês é equívoca porque induz à compreensão de que se trata de um dever sem que o seja, e a doutrina chama atenção para isso. No sistema jurídico da common law, o duty to mitigate the loss corresponde a uma norma que, conjuntamente com outras, determinam o valor da indenização da vítima de um dano contratual ou extracontratual. No sistema de imputação de danos da 
não agravar a sua perda ou o dano provocado pela contraparte. Caso o credor venha a atuar de maneira desidiosa e negligente e deixe de tomar as medidas cabíveis para mitigar as perdas, a doutrina da "mitigation of losses" entende que o devedor faltoso poderá pedir a redução das perdas e dos danos, em proporção idêntica ao montante que poderia ter sido evitado pelo credor $^{634}$.

Contudo, parcela da doutrina ${ }^{635}$ critica esse entendimento, uma vez que, mesmo em tal hipótese, ainda subsistiria para o devedor a possibilidade de retratar o seu repúdio à realização da prestação. Afirma-se que, em virtude da continuidade na aceitação do cumprimento da obrigação pelo credor, e também pelo aumento dos danos a transcorrer no tempo, haveria um estímulo para o devedor se retratar e voltar a adimplir. Os críticos da doutrina da "mitigation of losses" se baseiam na "preferência, especialmente no sistema romano-germânico, em manter o contrato sempre que possível”, ou seja, no princípio da conservação dos negócios jurídicos ${ }^{636}$.

common law, parte-se do princípio de que se deve indenizar todo o dano em alguma medida decorrente do delito ou do inadimplemento contratual. Diante de indenizações absurdamente elevadas que uma orientação como essa levaria, ao longo do tempo e por meio de decisões judiciais, casuisticamente foram sendo criados limites para ela, como, por exemplo, o de que o ofensor não deve indenizar danos que não poderia prever à época da contratação ou delito (remoneteness), ou os danos decorrentes da intervenção de causa estranha que rompa o nexo de causalidade (intervening cause), ou então os danos que a vítima poderia ter evitado mediante a ação de medidas razoáveis (duty to mitigate the loss). Tratam-se, assim, de pequenas regras, ou 'filtros' de imputação, que são confrontados com a totalidade de danos decorrentes do ilícito para se chegar ao valor devido da indenização reparatória (compensatory damages)". DIAS, Daniel Pires Novais. $O$ duty to mitigate the loss no Direito civil brasileiro e o encargo de evitar o próprio dano. p. 10. Disponível em: <http://www.revistas.unifacs.br/index.php/redu/article/view/1894>. Acesso em: 02 jun. 2013.

${ }^{634}$ ANDRADE, Luis Tomás Alves de. O Inadimplemento Antecipado do Contrato no Direito Brasileiro. $R$. EMERJ, Rio de Janeiro, v. 14, n. 56, p. 145-172, out-dez. 2011, p. 147. No mesmo sentido, Christian Sahb Batista Lopes afirma que "[...] se as pessoas resolveram desenvolver um projeto conjuntamente, usando a via contractual, a cooperação norteará não apenas a identificação das partes, suas tratativas, o cumprimento do contrato e a fase pós-contratual - conforme identificado anteriormente - como também o inadimplemento. Se aquele projeto conjunto não deu certo, por qualquer motivo, fazendo com que uma das contratantes descumpra suas obrigações, a outra deverá, não obstante, cooperar para que a frustração do projeto cause o menor prejuízo possível. A redução dos danos beneficiará não apenas a outra parte, mas, como visto no Capítulo III, favorecerá toda a economia contractual e evitará o desperdício de recursos econômicos que são socialmente relevantes". LOPES. Christian Sahb Batista. Mitigação dos prejuízos no direito contratual. São Paulo: Saraiva. 2013. p. 161.

${ }^{635}$ WASHOFSKY, Leonard. A. Contracts - Anticipatory Breach - Specific Performance. Tulane Law Review, v. XXXIII, 1959, p. 233.

636 BECKER, Anelise. Inadimplemento antecipado do contrato. Revista de Direito do Consumidor, São Paulo: Revista dos Tribunais, n. 12, 1994, p. 74. 
Apesar das críticas, o fato é que, em 1980, com a ratificação da Convention on Contracts for the International Sales of Goods (Convenção de Viena Sobre Venda Internacional de Mercadoria), a doutrina da "mitigation of losses" veio a ser positivada em diversos países do sistema da civil law, conforme se observa da redação do seu artigo 77: "a party who relies on a breach of contract must take such measures as are reasonable in the circumstances to mitigate the loss, including loss of profit, resulting from breach. If he fails to take such measures, the party in breach may claim a reduction in the damages in the amount by which the loss should have been mitigated."637

Os princípios UNIDROIT relativos aos Contratos Comerciais Internacionais também se orientam no mesmo sentido: “Artigo 7.4.8(1). A parte inadimplente não é responsável por danos sofridos pela parte prejudicada na medida em que esses danos poderiam ter sido reduzidos com a adoção de medidas razoáveis por parte desta." A respeito do referido princípio, João Baptista Villela comenta que o objetivo desse artigo é "evitar que a parte prejudicada adote uma postura passiva e aguarde ser indenizada por danos que poderiam ter sido evitados ou reduzidos". ${ }^{638} \mathrm{O}$ autor complementa afirmando que qualquer dano que a parte prejudicada poderia ter evitado tomando medidas razoáveis não será indenizado pela parte inadimplente, posto que isso não seria razoável do ponto de vista econômico.

Confiram-se dois exemplos do dever de mitigar danos formulados por João Baptista Villela que são bastante ilustrativos:

\footnotetext{
${ }^{637}$ Em tradução livre: "uma parte que se baseia no inadimplemento contratual deve tomar as medidas razoáveis conforme as circunstâncias para mitigar as perdas e danos, inclusive perda de lucro, resultante do inadimplemento. Caso falhe em tomar tais medidas, a parte inadimplente poderá reivindicar uma redução na indenização no montante pelo qual a perda deveria ter sido mitigada." Em comentários sobre o referido dispositivo, Schlechtriem \& Schwenzer afirmam que "o art. 77 adota o princípio, já contido no art. 84 da ULIS, qual seja, o de que a parte que possui direito à indenização por perdas e danos deve mitigar os próprios prejuízos. O dever que recai sobre a parte lesada, no sentido de tomar as medidas possíveis e apropriadas a fim de evitar a ocorrência de prejuízos ou mitigar a sua extensão é uma expressão do princípio geral da boafé no comércio internacional". SCHLECHTRIEM, Peter; SCHWENZER, Ingeborg. Comentários à Convenção das Nações Unidas sobre Contratos de Compra e Venda Internacional de Mercadorias. Coordenação de tradução de Eduardo Grebler, Vera Fradera, César Guimarães Pereira. São Paulo: Editora Revista dos Tribunais. 2014. p. 1.149.

638 VILLELA, João Baptista et al. Princípios UNIDROIT Relativos aos Contratos Comerciais Internacionais/2004 [versão em língua portuguesa]. São Paulo: Quartier Latin. 2009. p. 259.
} 
1. Em 2 de maio, A pede a B, uma agência de viagens, para reservar um quarto de hotel em Paris para $1^{\circ}$ de junho, pelo preço de 200,00 euros. Em 15 de maio, A descobre que B não fez a reserva. A espera, entretanto, até 25 de maio antes de fazer outra reserva e só consegue achar um quarto pelo preço de 300,00 euros, ao passo que as acomodações poderiam ter sido garantidas por 250,00 euros se A tivesse agido já em 15 de maio. A pode reaver apenas 50,00 euros de B.

2. A, uma companhia a quem B confiou a construção de uma fábrica, repentinamente interrompe seus trabalhos quando o projeto se aproxima de seu fim. B procura outra companhia para terminar a construção do terreno, cujas condições deterioram-se em razão do mau tempo. B não pode reaver compensação pela deterioração, vez que essa é atribuível a sua falha de requerer medidas provisórias de proteção. ${ }^{639}$

A obra Principles, definitions and model rules of european private law, em que consta um esboço de Código Civil a ser adotado nos países que compõem a União Europeia - Draft Common Frame of Reference (DCFR) - também reconhece o duty to mitigate the loss, nos seguintes termos: "the debtor is not liable for the loss suffered by the creditor to the extent that the creditor contributed to the non-performance or its effects." 640

A doutrina brasileira tem se manifestado favoravelmente à recepção do duty to mitigate the $\operatorname{loss}^{641}$. Apesar de a doutrina da mitigação das perdas não ter sido prevista em norma expressa no nosso ordenamento ${ }^{642}$, ela passou a ser vista pela doutrina como decorrência do princípio da boa-fé objetiva ${ }^{643}$. Segundo Christian Sahb Batista Lopes,

639 VILLELA, João Baptista et al. Princípios UNIDROIT relativos aos Contratos Comerciais Internacionais/2004 [versão em língua portuguesa]. São Paulo: Quartier Latin. 2009. p. 260.

${ }^{640}$ VON BAR, Christian, CLIVE, Eric. Principles, Definitions and Mode, Rules of European Private Law. Draft Common Frame of Reference (DCRF). Full Edition. v. I. Sellier. p. 934. Em tradução livre: "o devedor não é responsável pelo prejuízo sofrido pelo credor na medida em que o credor contribuiu para o inadimplemento ou seus efeitos."

641 TARTUCE, Flávio. A boa-fé e a mitigação do prejuízo pelo credor. Esboço do tema e primeira abordagem. Março de 2005. Disponível em: 〈www.flaviotartuce.adv.br/secoes/artigos/Tartuce duty.doc〉. Acesso em: 30 jun. 2013. PEIXOTO, Alessandra Cristina Tufvesson. Responsabilidade extracontratual Algumas considerações sobre a participação da vítima na quantificação da indenização . Revista da Emerj, v.11, n.44, 2008.

642 Não obstante o ordenamento jurídico brasileiro não conter dispositivo que imponha expressa e genericamente ao credor o dever de mitigar seus danos, é possível identificar ao menos três artigos do Código Civil que refletem, em situações específicas, a preocupação do legislador com o agravamento de danos. Trata-se do artigo 430, que impõe ao proponente o dever de comunicar imediatamente ao aceitante o recebimento tardio da aceitação, por circunstância imprevista, sob pena de responder por perdas e danos; do artigo 769, pelo qual o segurado é obrigado a comunicar ao segurador, logo que saiba, todo incidente suscetível de agravar consideravelmente o risco coberto, sob pena de perder o direito à garantia, se provar que silenciou de má-fé; e do artigo 771, segundo o qual o segurado deverá informar sobre o sinistro ao segurados logo que o saiba e tomará todas as consequências para minorar as suas consequências, sob pena de perder o direito à indenização.

${ }^{643}$ Sobre o tema, importante lembrar a doutrina de Alessandra Cristina Tufvesson Peixoto: "2. DUTY TO MITIGATE THE LOSS. Vista a relevância da vítima para o estabelecimento da indenização adequada, trato 
autor de obra específica sobre o assunto, “a integração da cláusula geral da boa-fé objetiva com valores e finalidades adotados pela ordem jurídica nacional impõe a adoção da norma de mitigação no direito brasileiro" 644 .

Entende-se que "o duty to mitigate the loss poderia ser considerado um dever acessório, derivado do princípio da boa-fé objetiva, pois nosso legislador, com o apoio da doutrina anterior ao atual Código, adota uma concepção cooperativa de contrato" ${ }^{\text {645 }}$. O duty to mitigate é visto como uma concretização da noção de cooperação imposta pela boafé, uma vez que impõe a uma das partes conduta voltada a evitar a oneração da prestação da outra. Na mesma direção aprovou-se, na III Jornada de Direito Civil, o Enunciado ${ }^{\circ}$ 169, segundo o qual "o princípio da boa-fé objetiva deve levar o credor a evitar o agravamento do próprio prejuízo".

A teoria do duty to mitigate the loss foi aceita pela doutrina brasileira para solucionar situações em que o credor mantém-se inerte diante da produção ou agravamento do próprio prejuízo decorrente do inadimplemento do contrato. Trata-se de solução apresentada para "um problema de responsabilidade civil contratual, ou seja, um problema de imputação de danos que o credor inadimplido poderia ter evitado sofrer ou mesmo minimizado sua extensão quando já inicialmente configurado"646.

De maneira geral, a doutrina pátria aponta que os pressupostos necessários à caracterização do dever de mitigar o dano são os seguintes: (i) inadimplemento contratual;

de instituto que vem sendo desenvolvido no direito estrangeiro e que começa a ser estudado no direito brasileiro. Trata-se do duty to mitigate the loss, ou mitigação do prejuízo pelo próprio credor. O fundamento para esse dever está diretamente ligado ao dever de boa-fé que deve existir entre os contratantes e entres os indivíduos, em geral. Tem-se como conceito de boa-fé o dever de agir, nas relações sociais, de acordo com certos padrões mínimos de conduta socialmente recomendados, de lealdade, correção ou lisura, aos quais correspondem expectativas legítimas das pessoas." PEIXOTO, Alessandra Cristina Tufvesson. Responsabilidade extracontratual - Algumas considerações sobre a participação da vítima na quantificação da indenização. Revista da Emerj, v. 11, n. 44, 2008, p. 135-136.

${ }^{644}$ LOPES. Christian Sahb Batista. Mitigação dos prejuízos no direito contratual. São Paulo: Saraiva. 2013. p. 163.

${ }^{645}$ FRADERA, Véra Maria Jacob de. Pode o Credor ser Instado a Diminuir o Próprio Prejuízo? Revista Trimestral de Direito Civil, Rio de Janeiro, n. 19, jul./set. 2004, p. 116.

${ }^{646}$ DIAS, Daniel Pires Novais. O duty to mitigate the loss no Direito civil brasileiro e o encargo de evitar o próprio dano. p. 13. Disponível em: <http://www.revistas.unifacs.br/index.php/redu/article/view/1894>. Acesso em: 02 jun. 2013. 
(ii) existência de um dano imputável à parte inadimplente; e (iii) a possibilidade de o credor conter a repercussão desse dano, se agir de acordo com a diligência ordinária ${ }^{647}$.

A jurisprudência brasileira também já se posicionou no sentido de que o duty to mitigate the loss foi acolhido no direito pátrio como uma decorrência dos deveres anexos impostos pela boa-fé objetiva e que as partes contratantes devem tomar as medidas necessárias e possíveis para que os danos não sejam agravados, como se observa do trecho do acórdão do Superior Tribunal de Justiça abaixo transcrito:

\begin{abstract}
Assim, a boa-fé objetiva afigura-se como standard ético-jurídico a ser observado pelos contratantes em todas as fases contratuais. Ou seja, durante as diversas etapas do contrato, a conduta das partes deve ser pautada pela probidade, cooperação e lealdade.

Destarte, a boa-fé objetiva é fonte de obrigação que permeia a conduta das partes a influir na maneira em que exercitam os seus direitos, bem como no modo em que se relacionam entre si. Neste rumo, a relação obrigacional deve ser desenvolvida com o escopo de se preservarem os direitos dos contratantes na consecução dos fins avençados, sem que a atuação das partes infrinja os preceitos éticos insertos no ordenamento jurídico.

Com esse entendimento, avulta-se o dever de mitigar o próprio prejuízo, ou, no direito alienígena, duty to mitigate the loss: as partes contratantes da obrigação devem tomar as medidas necessárias e possíveis para que o dano não seja agravado. Desse modo, a parte a que a perda aproveita não pode permanecer deliberadamente inerte diante do dano, pois a sua inércia imporá gravame desnecessário e evitável ao patrimônio da outra, circunstância que infringe os deveres de cooperação e lealdade. ${ }^{648}$
\end{abstract}

Parcela da doutrina defende que o duty to mitigate the loss também deveria ser aplicado em casos de inadimplemento antecipado, em que o devedor declara que não irá adimplir ou que o seu comportamento revela isso, para evitar um agravamento dos danos a serem sofridos pelas partes. Com relação ao dever de mitigar os danos na hipótese de inadimplemento antecipado, Fortunato Azulay assevera que:

Esta orientação jurisprudencial tem particular aplicação e importância nos casos de repúdio antecipado do contrato. A ruptura antes do termo pode ter várias causas, alheias à vontade do devedor, embora lhe possam ser imputadas e gerar danos às vezes irreparáveis ou de reflexos sociais e trabalhistas bem graves. É

\footnotetext{
${ }^{647}$ ZANETTI, Cristiano de Souza. A Mitigação do Dano e Alocação da Responsabilidade. Revista Brasileira de Arbitragem, $\mathrm{n}^{\mathrm{o}} 35$, jul/set 2012, p. 31 .

${ }^{648}$ STJ, Recurso Especial $n^{\circ}$ 758.518, $3^{\mathrm{a}}$ Turma, Rel. Ministro Vasco Della Giustina, j. 17.06.2010. Disponível em: <http://www.stj.jus.br/SCON/>. Acesso em: 20 maio 2013.
} 
por isso uma necessidade prevenir, reduzir ou tentar minimizar os danos, em vez de assistir passivamente ao nascimento e progressão da lesão. ${ }^{649}$

Estamos de acordo com essa parcela da doutrina. Com efeito, os pressupostos necessários à caracterização do duty to mitigate the loss podem ser constatados no inadimplemento antecipado do contrato, a saber: (i) a inexecução contratual, ainda que antes do termo pactuado entre as partes; (ii) o inadimplemento do contrato por ato ou fato imputável à parte inadimplente; e (iii) e a possibilidade de o credor agir para conter a repercussão dos danos sofridos em decorrência da quebra antecipada do contrato.

Seria muita incongruência considerar que a inércia do credor frente ao comportamento do devedor que conduzisse ao inadimplemento antecipado não configurasse afronta ao dever de probidade. A nosso ver, só se pode considerar probo e honesto o credor que - ao tomar conhecimento do inadimplemento antecipado - realiza desde logo os atos necessários e recomendados para minorar o prejuízo que lhe foi causado. A inércia do credor acarretará o agravamento dos danos causados pelo devedor, não sendo possível imputar ao devedor responsabilidade por este incremento dos danos, o qual deveria ser suportado pelo próprio credor.

Para contextualizar a aplicação do duty to mitigate the loss ao inadimplemento antecipado, reproduza-se o seguinte exemplo trazido pela doutrina ${ }^{650}$ : determinada companhia de aviação teria encomendado três aeronaves para serem entregues em dois anos da contratação. Passados dois meses, o fabricante de aviões declara expressamente

\footnotetext{
${ }^{649}$ AZULAY, Fortunato. Do inadimplemento antecipado do contrato. Rio de Janeiro: Editora Brasília/Rio. 1977. p. 53. No mesmo sentido: Robert E. Scott e Jody S. Kraus afirmam: "the doctrine of anticipatory repudiation, then, might serve to extend the duty of mitigation to a period before the time for performance has expired. Because it potentially enables the parties to avoid wasteful actions taken in reliance on performance when subsequent events lead one or both parties to believe performance has become unlikely or impossible, it brings actual contracts closer to the ideal contract, which would require parties to make all cost-effective adjustments to events occurring after formation." SCOTT, Robert E. and KRAUS, Jody S. Contract law and theory. 4th ed. LexisNexis. 2007. p. 816. Em tradução livre: "a doutrina do inadimplemento antecipado poderia, então, servir para estender o dever de mitigar para um período anterior ao prazo do termo contratual. Isso porque o instituto potencialmente permite que as partes evitem tomar ações desnecessárias ao cumprimento quando eventos subsequentes levam uma ou ambas as partes a acreditarem que o cumprimento se tornou improvável ou impossível, trazendo, assim, contratos reais mais próximos ao contrato ideal, o que exigiria que as partes a realizassem ajustes efetivos de custos para os eventos que ocorrerem após a formação."

${ }^{650}$ LABOURIAU, Miguel. Algumas considerações sobre o inadimplemento antecipado no direito brasileiro. Revista Trimestral de Direito Civil, v. 42, abril/junho 2010, Padma, Rio de Janeiro, p. 114-115.
} 
não poder realizar a prestação. Nesse caso, é plenamente justificável que a companhia busque os meios resolutórios em tempo hábil e extinga o contrato com base na figura do inadimplemento antecipado. Isso porque, caso a companhia permaneça inerte e aguarde o advento do termo contratual para tomar alguma providência, os danos que the serão causados alcançarão proporções muito maiores e talvez até irreparáveis ${ }^{651}$.

Entende-se que a possibilidade de invocar o inadimplemento antecipado transcende o aspecto do direito, para se tornar também um dever imposto ao credor. A configuração do inadimplemento antecipado impõe ao credor o dever de mitigação dos danos, a exemplo do duty to mitigate the loss da common law, pelo qual a parte que invoca o descumprimento contratual tem o dever de tomar, assim que possível, todas as medidas razoáveis para limitar o dano. Uma vez configurado o inadimplemento antecipado, cuja ocorrência é de conhecimento do credor, ele tem o dever de adotar imediatamente as medidas cabíveis para não permitir o aumento dos seus danos e, consequentemente, não agravar a situação do devedor inadimplente.

Caminhando para a mesma conclusão, Anelise Becker afirma que:

\begin{abstract}
Considerar o contrato desde logo violado deixa de constituir-se num direito (que pode ser exercido ou não) para transmutar-se em dever, sob pena de configurarse abuso no seu não exercício, face ao prejuízo que inflige ao contratante, ainda que este, por atos, declarações ou por manter-se inerte haja violado o contrato.

Fundamentalmente, portanto, é a doctrine of mitigation que determina a possibilidade da quebra antecipada do contrato: a parte, mesmo lesada pela violação do contrato, deve agir de forma a não agravar a perda ou dano da contraparte. Se o contratante lesado pela recusa em adimplir da contraparte fosse obrigado (e, em certos casos, se tal lhe fosse permitido) a manter o contrato, ou seja, a cumprir com sua parte no advento do termo, mesmo sabendo que não receberá a contraprestação, a indenização que seria exigida do devedor inadimplente seria maior, porque relativa ao preço de todo o contrato, do que aquela que teria exigido ao considera-lo como desde logo rompido, sem ter que, portanto, implementar a sua prestação. ${ }^{652}$
\end{abstract}

\footnotetext{
${ }^{651}$ Em 2004, Véra Maria Jacob de Fradera publicou artigo intitulado Pode o credor ser instado a diminuir o próprio prejuízo?, expondo que em diversos sistemas jurídicos internacionais o credor, em face do inadimplemento do contrato, encontra-se adstrito a adotar medidas tendentes a minimizar as próprias perdas decorrentes do inadimplemento, sob pena de ter a sua indenização reduzida em proporção equivalente ao montante de danos que poderiam ter sido evitados. FRADERA, Véra Maria Jacob de. Pode o Credor ser Instado a Diminuir o Próprio Prejuízo? Revista Trimestral de Direito Civil, Rio de Janeiro, n. 19, jul./set. 2004, p. 109-119.

${ }^{652}$ BECKER, Anelise. Inadimplemento antecipado do contrato. Revista de Direito do Consumidor, São Paulo: Revista dos Tribunais, n. 12, 1994. p. 74.
} 
Como se verá adiante, a inobservância do dever de mitigar danos terá repercussão importante no cálculo do montante indenizatório a que o credor fará jus em caso de inadimplemento antecipado. Isso porque, demonstrada a violação ao dever de mitigar danos, caberá ao juiz reduzir o montante indenizatório, eximindo o devedor da responsabilidade pelos danos causados e agravados em virtude do comportamento do credor. É assim que se posiciona Fortunato Azulay:

\begin{abstract}
A harmonia social e o interesse coletivo sobrelevam o individual, motivo por que a parte que vem sendo lesada pela pré-inadimplência do outro contratante deverá providenciar pelos meios legais a seu alcance a não-extensão do dano. Tal entendimento já resultava do art. 254, al. 2, do BGB, em virtude do qual o tribunal pode recusar ou diminuir a reparação devida ao lesado se este omitiu de avisar o devedor do perigo de um dano particularmente elevado, que este não conhecia nem tinha meios de conhecer; ou se se omitiu de prevenir ou reduzir o dano. ${ }^{653}$
\end{abstract}

Por fim, cumpre observar que o duty to mitigate the loss não poderá impor que o credor tome medidas para mitigar os danos que lhe consumam tempo, dinheiro ou recursos excessivos, que não fossem adotadas pelo homem médio em uma determinada situação de inadimplemento antecipado. É nesse sentido que João Baptista Villela assevera que "evidentemente, não se pode exigir que uma parte que já tenha sofrido as consequências do inadimplemento do contrato também tome medidas que consumam tempo ou dinheiro" ${ }^{\circ 54}$.

O dever de mitigar os danos deve ser aplicado com parcimônia e pautado pelos princípios da proporcionalidade e da razoabilidade, para que não se transfira ao credor o

653 AZULAY, Fortunato. Do inadimplemento antecipado do contrato. Rio de Janeiro: Editora Brasília/Rio. 1977. p. 52.

654 VILLELA, João Baptista et al. Princípios UNIDROIT relativos aos Contratos Comerciais Internacionais/2004 [versão em língua portuguesa]. São Paulo: Quartier Latin. 2009. p. 259-260. No mesmo sentido: "o art. 77 [da Convention on Contracts for the International Sales of Goods] impõe à parte detentora de direito à indenização que tome as medidas razoáveis a fim de mitigar as perdas possivelmente esperadas, nas circunstâncias em que é considerado o princípio da boa-fé. Para se determinar quais medidas são razoáveis, deve-se primeiramente, levar em consideração as práticas entre as partes, bem como os usos do comércio internacional (art. 9). Em todos os outros aspectos, o ponto de referência é a conduta de uma pessoa razoável, na mesma posição e sob as mesmas circunstâncias da parte lesada (art. 8(2)). O promissário não está obrigado a tomar medidas envolvendo custos extraordinários e desproporcionalmente elevados." SCHLECHTRIEM, Peter; SCHWENZER, Ingeborg. Comentários à Convenção das Nações Unidas sobre Contratos de Compra e Venda Internacional de Mercadorias. Coordenação de tradução de Eduardo Grebler, Vera Fradera, César Guimarães Pereira. São Paulo: Editora Revista dos Tribunais. 2014. p. 1.152. 
ônus de sempre agir no lugar do devedor quando este declarar ou manifestar pelo seu comportamento que o contrato será inadimplido antecipadamente. Conforme adverte Cristiano de Souza Zanetti, “o chamado 'dever de mitigar o dano' encontra-se novamente em evidência no século XXI. O desafio, agora, é manejá-lo de maneira criteriosa, o que exigirá, cada vez e sempre, o emprego atento do conceito de razoabilidade ao caso com que se deparará o profissional encarregado de interpretá-lo segundo as regras do Direito" $^{, 655}$.

Caberá ao juiz, diante das particularidades do caso concreto (por exemplo: risco de agravamento do dano, situação econômico-financeira do credor, grau de recursos materiais e humanos necessários para evitar o aumento dos danos, etc.), analisar com cautela quais medidas razoavelmente se poderia esperar que o credor tivesse tomado para evitar o agravamento dos danos em uma situação de inadimplemento antecipado do contrato. Feita essa análise, se se caracterizar que o credor se quedou inerte quando deveria ter agido, o montante indenizatório deverá ser reduzido proporcionalmente à omissão do credor. Deverá, obviamente, haver um nexo de causalidade adequado entre a inércia do credor quanto ao seu dever de mitigar os danos e o agravamento dos danos, cabendo ao devedor o ônus de provar isso.

${ }^{655}$ ZANETTI, Cristiano de Souza. A Mitigação do Dano e Alocação da Responsabilidade. Revista Brasileira de Arbitragem, $\mathrm{n}^{\circ}$ 35, jul/set 2012, p. 36. 


\section{EFEITOS DO INADIMPLEMENTO ANTECIPADO DO CONTRATO}

\subsection{Generalidades sobre os efeitos do inadimplemento antecipado do contrato}

Depois de estabelecidos os contornos gerais do inadimplemento antecipado no ordenamento jurídico brasileiro e estudados os seus fundamentos e limites, tem-se como passo final investigar quais são os efeitos atribuíveis ao inadimplemento antecipado do contrato.

Os efeitos do inadimplemento antecipado variam conforme o fundamento a que se atribui o instituto; de acordo com o fundamento indicado, os efeitos podem ser mais ou menos amplos ${ }^{656}$. Conclui-se, assim, que a correta identificação da natureza jurídica do instituto é fundamental, para não limitar os efeitos produzidos pelo inadimplemento antecipado e não restringir os meios de tutela que podem ser utilizados pelo credor para a defesa do seu direito.

Como exposto no segundo capítulo, entendemos que o inadimplemento antecipado é uma situação ordinária de inadimplemento que, conforme o caso concreto, configurar-se-ia como mora ou como inadimplemento absoluto, a depender da possibilidade de cumprimento da prestação (na acepção técnico-jurídica do termo “possibilidade") e da permanência de utilidade da prestação para o credor.

Nessa visão, se o devedor descumpre um dever obrigacional (principal, secundário ou lateral), acarretando o inadimplemento antecipado do contrato, configura-se

\footnotetext{
656 Por exemplo, os autores que identificam no inadimplemento antecipado uma situação de préinadimplência e a equiparam às hipóteses de vencimento antecipado da dívida, atribuem àquela os efeitos destas. Por consequência, confere-se ao credor "o direito de ingressar com a ação competente para exigir a mantença do contrato com a consequente exigibilidade da prestação ou a sua rescisão com perdas e danos". AZULAY, Fortunato. Do inadimplemento antecipado do contrato. Rio de Janeiro: Editora Brasília/Rio. 1977. p. 115. Por outro lado, aqueles que enquadram o inadimplemento antecipado como uma hipótese de "violação positiva do contrato" reconhecem ao credor direito imediato à resolução do contrato e perdas e danos, mas não à execução específica, cuja admissibilidade, segundo se afirma, estaria subordinada ao advento do termo. DUARTE, Adriana Dardengo. A quebra do contrato por repúdio antecipado no direito brasileiro: proposta de aplicação de uma teoria. Dissertação apresentada ao curso de mestrado da Universidade Federal de Minas Gerais, 2006.
} 
(i) inadimplemento absoluto, se a prestação se tornar impossível de ser adimplida ou inútil para o credor; ou (ii) mora, nos casos em que a inobservância do dever de conduta ensejar apenas o retardamento da prestação, ou o cumprimento da prestação em desacordo com o tempo, modo e lugar pactuados, sem lhe retirar a utilidade para o credor.

$\mathrm{O}$ reconhecimento de que o inadimplemento antecipado se fundamenta no inadimplemento da prestação devida permite atribuir-lhe todos os efeitos das categorias clássicas do inadimplemento (inadimplemento absoluto e mora) - inclusive, a demanda de cumprimento -, que podem ser produzidos imediatamente, em virtude da perda do benefício do termo pelo devedor ${ }^{657}$.

Qualquer que seja o seu suporte fático, o primeiro efeito do inadimplemento antecipado reside na imposição, ao devedor, do dever de indenizar os danos causados ${ }^{658}$, conforme dispõe o artigo 389 do Código Civil $^{659}$. Os demais efeitos dependem da possibilidade de o credor receber a prestação devida. Configurado o inadimplemento absoluto, confere-se ao credor duas opções: ajuizar ação visando à resolução contratual, ou ao cumprimento do contrato, se preferir mantê-lo (artigo 475 do Código Civil ${ }^{660}$ ). Por outro lado, configurada a mora do devedor, abre-se ao credor apenas esta última alternativa.

\footnotetext{
657 TERRA, Aline de Miranda Valverde. Inadimplemento anterior ao termo. Rio de Janeiro: Renovar. 2009. p. 243. No mesmo sentido, Nelson Rosenvald afirma que: "o dispositivo [art. 477 do Código Civil] tangencia a chamada quebra antecipada do contrato, ou inadimplemento antecipado. Consiste na evidência de um dos contratantes implicitamente demonstrar, por meio de sua situação patrimonial, que descumprirá futuramente a prestação que lhe incumbe. Ou seja, a prestação a ser inadimplida ainda não é exigível pelo credor, mas provavelmente não será realizada ao seu tempo. O rompimento antecipado poderá ser pleiteado caso o contratante fragilizado não obtenha as novas garantias que lhe são exigidas. Poderá o credor, imediatamente, ajuizar ação de resolução com pedido de indenização ou executar a prestação da contraparte antes do prazo previsto, mediante a tutela específica das obrigações de dar, fazer ou não fazer (art. 461 do CPC)." ROSENVALD, Nelson. Código Civil comentado. PELUSO, Cezar (Coord.). Barueri/SP: Manoele. 2007. p. 372-373.

${ }^{658}$ Judith Martins-Costa afirma que "o pagamento das perdas e danos é efeito da obrigação de indenização, que nasce com o inadimplemento imputável. Seu escopo é, segundo fórmula clássica, o de 'recolocar a vítima na situação em que ela se encontraria se o prejuízo não tivesse sido produzido"”. MARTINS-COSTA, Judith. Comentários ao novo Código Civil: do inadimplemento das obrigações. v. V. tomo 2. Rio de Janeiro: Forense. 2003. p. 323.

659 “Art. 389. Não cumprida a obrigação, responde o devedor por perdas e danos, mais juros e atualização monetária segundo índices oficiais regularmente estabelecidos, e honorários advocatícios.”

660 “Art. 475. A parte lesada pelo inadimplemento pode pedir a resolução do contrato, se não preferir exigirlhe o cumprimento, cabendo, em qualquer dos casos, a indenização por perdas e danos."
} 
Importante observar que os efeitos do inadimplemento antecipado se subordinam às peculiaridades do caso concreto. Deve-se permitir ao juiz, diante do caso que lhe é apresentado e à luz da boa-fé objetiva, sopesar os interesses em jogo a fim de verificar a legitimidade do mecanismo de tutela requerido pelo credor em face do inadimplemento do devedor, especialmente no que se refere à resolução contratual, que é medida extrema ${ }^{661}$.

Insta, portanto, examinar cada uma das possibilidades colocadas à disposição do credor diante do inadimplemento antecipado do contrato.

\subsection{Perdas e danos}

Tanto no inadimplemento absoluto quanto na mora, a principal consequência prevista para o inadimplemento (em sentido amplo) consiste na obrigação de indenizar ${ }^{662} \mathrm{o}$ prejuízo causado ao credor. Conforme observa Antunes Varella, "o não cumprimento (inadimplemento ou inadimplência do devedor) da obrigação tem, assim, como principal consequência, a possibilidade de o credor exigir do faltoso o cumprimento judicial da prestação debitória, acrescida do valor dos danos que esse facto ilícito lhe causou"663.

A parte prejudicada pelo inadimplemento pode requerer que a indenização por perdas e danos seja aplicada como medida jurídica exclusiva (por exemplo, danos pelo atraso no caso de adimplemento tardio ou adimplemento defeituoso aceito pela parte prejudicada) ou em conjunto com outras medidas jurídicas ${ }^{664}$. Assim, além do pedido de

${ }^{661}$ TERRA, Aline de Miranda Valverde. Inadimplemento anterior ao termo. Rio de Janeiro: Renovar. 2009. p. 245.

${ }^{662}$ Consoante destaca Araken de Assis, a indenização por perdas e danos não é efeito da resolução do contrato, mas do inadimplemento, razão pela qual também é cabível na demanda de cumprimento. Confirase: "seja como for, a indenização representa direito autônomo. É uma sanção, baseada no ilícito, e provoca a necessidade de investigação da culpa, a teor do art. 392 do CC-02, quiçá criando ao aplicador desavisado a ilusão de que toda demanda resolutória gravita em torno de tal parcela da causa petendi." ASSIS, Araken de. Resolução do contrato por inadimplemento. 4. ed. rev. e atual. São Paulo: Editora Revista dos Tribunais. 2004. p. 149.

${ }^{663}$ VARELA, João de Mattos Antunes. Das obrigações em geral. Coimbra: Almedina. 1970. p. 758.

${ }^{664}$ Neste sentido, os princípios UNIDROIT relativos aos Contratos Comerciais Internacionais preveem que: "qualquer inadimplemento dá à parte prejudicada o direito à indenização por perdas e danos, seja em caráter exclusivo, seja em conjunto com outras medidas jurídicas, exceto quando o inadimplemento seja dispensado segundo estes Princípios." (artigo 7.4.1) 
indenização, a parte poderá pleitear cumulativamente ${ }^{665}$ a resolução ou o cumprimento do contrato, a depender do caso concreto ${ }^{666}$.

É importante mencionar que a indenização a ser paga pela parte que provocou o inadimplemento deverá abranger tanto o dano emergente (o que a parte efetivamente perdeu) quanto o lucro cessante (o que a parte razoavelmente deixou de ganhar), consoante a previsão dos artigos $402^{667}$ e $403^{668}$ do Código Civil, de modo a permitir a mais ampla e completa reparação dos prejuízos causados pelo inadimplemento ${ }^{669}$.

Como averba Agostinho Alvim, em ensinamento ainda atual:

[...] se, como dizem os civilistas, para a verificação cabal do dano, devemos ter em vista o patrimônio daquele que o sofreu, tal como estaria se não existira o dano, bem se vê desde logo, a necessidade de levar em conta não somente o desfalque, mas aquilo que não entrou ou não entrará para este patrimônio, em virtude de certo fato danoso. Assim que, o dano, em toda a sua extensão, há de abranger aquilo que efetivamente se perdeu e aquilo que se deixou de lucrar. ${ }^{670}$

A indenização deverá contemplar todos os danos decorrentes da conduta do devedor que deu causa ao inadimplemento, abrangendo tanto os interesses negativos ${ }^{671}$

\footnotetext{
665 Araken de Assis afirma que “[...] se ao lado do retorno ao estado anterior, o parceiro almeja obter indenização, cabe pedi-la cumulativamente ao pedido resolutório. É exemplo de cumulação facultativa de ações, sob a forma de cúmulo sucessivo de pedidos." ASSIS, Araken de. Resolução do contrato por inadimplemento. 4. ed. rev. e atual. São Paulo: Editora Revista dos Tribunais. 2004. p. 145.

666 Judith Martins-Costa observa que "as perdas e danos podem ter um caráter substitutivo ao cumprimento da obrigação principal (indenização pelo equivalente pecuniário, que cumulará as perdas e danos moratórios e compensatórios) ou servirão apenas para reparar os danos que ainda ficaram, em razão da mora (perdas e danos moratórios)". MARTINS-COSTA, Judith. Comentários ao novo Código Civil: do inadimplemento das obrigações. v. V. tomo 2. Rio de Janeiro: Forense. 2003. p. 323.

667 “Art. 402. Salvo as exceções expressamente previstas em lei, as perdas e danos devidas ao credor abrangem, além do que ele efetivamente perdeu, o que razoavelmente deixou de lucrar."

668 “Art. 403. Ainda que a inexecução resulte de dolo do devedor, as perdas e danos só incluem os prejuízos efetivos e os lucros cessantes por efeito dela direto e imediato, sem prejuízo do disposto na lei processual."

${ }^{669}$ Sobre o assunto, julgou o Superior Tribunal de Justiça que "a inexecução do contrato pelo promitentevendedor que não entrega o imóvel na data acarreta, além do dano emergente, figurado nos valores das parcelas pagas pelo promitente-comprador, lucros cessantes a título de alugueres que poderia o imóvel ter rendido se tivesse sido entregue na data contratada". (STJ, AgRg no Resp 1.049.894/RJ, 3ª Turma, Rel. Min. Vasco Della Giustiana, DJe 26.10.2010)

${ }^{670}$ ALVIM, Agostinho. Da inexecução das obrigações e suas consequências. 3. ed. atual. Rio de Janeiro: Editora Jurídica e Universitária Ltda. 1949. p. 173.

${ }^{671}$ Segundo Judith Martins-Costa "o interesse negativo aponta para a situação em que o credor se encontraria se não tivesse celebrado o contrato, ou entrado em negociações que se viram injustamente frustradas, seja pelo recesso injustificado de uma das partes, seja pela não-dação de informações que teriam sido relevantes para formar o consenso contratual, seja pelo não-cumprimento de promessas feitas na fase pré-contratual que
} 
(prejuízos sofridos em virtude da conclusão do contrato) quanto os interesses positivos ${ }^{672}$ (situação em que a parte se encontraria caso o contrato tivesse sido cumprido) da parte prejudicada, consoante observa Ruy Rosado Aguiar Júnior:

\begin{abstract}
A composição dos danos pode compreender interesses negativos e positivos. $\mathrm{O}$ interesse negativo é o "dano derivado da confiança", conseqüente ao fato de ter a parte confiado no contrato, para cuja celebração e cumprimento pode ter efetuado despesas e assumido obrigações, preterindo outras alternativas [...]. A indenização pelo interesse negativo há de repor o lesado na situação em que estaria, hoje, não tivesse contado com a eficiência do contrato. $\mathrm{O}$ interesse positivo é o interesse de cumprimento; corresponde ao aumento que o patrimônio do credor teria experimentado se o contrato tivesse sido cumprido. É o acréscimo que o contratante, caso fosse cumprido, auferiria com o valor da prestação, descontado o valor da contraprestação, e mais a vantagem decorrente da disponibilidade desse acréscimo, desde o dia previsto para o cumprimento até o dia da indenização. ${ }^{673}$
\end{abstract}

Impõe-se sublinhar que somente o déficit patrimonial que decorra direta e exclusivamente da conduta da parte faltosa pode ser encarado como prejuízo ressarcível ${ }^{674}$. Essa imediatividade e exclusividade causal não se verifica quando o dano não tem como única origem o descumprimento do contrato, pressupondo outros elementos coadjuvantes e originais que diluem a relação de causalidade. Em outros termos, indenizam-se apenas os prejuízos reais e concretos, jamais ganhos hipotéticos, decorrentes diretamente do inadimplemento contratual ${ }^{675}$.

geraram a justa expectativa do credor, etc.". MARTINS-COSTA, Judith. Comentários ao novo Código Civil: do inadimplemento das obrigações. v. V. tomo 2. Rio de Janeiro: Forense. 2003. p. 329-330).

${ }^{672}$ Segundo Judith Martins-Costa, "o interesse positivo, ou 'interesse de cumprimento' ou, ainda, 'dano positivo', é o que resultaria para o credor, do cumprimento exato do contrato. Assim sendo, a indenização do interesse positivo destina-se a colocar o lesado na situação em que se encontraria se o contrato fosse exatamente cumprido, reconduzindo-se aos prejuízos que decorrem do não-cumprimento definitivo do contrato, ou do cumprimento tardio ou defeituoso". MARTINS-COSTA, Judith. Comentários ao novo Código Civil: do inadimplemento das obrigações. v. V. tomo 2. Rio de Janeiro: Forense. 2003. p. 329.

${ }^{673}$ AGUIAR JÚNIOR, Ruy Rosado de. Extinção dos contratos por incumprimento do devedor. 2. ed. Rio de Janeiro: AIDE. 1991. p. 263. Em sentido contrário, Araken de Assis entende que o Código Civil brasileiro só contempla o interesse negativo. ASSIS, Araken de. Resolução do contrato por inadimplemento. 4. ed. rev. e atual. São Paulo: Editora Revista dos Tribunais. 2004. p. 146.

${ }^{674}$ A esse respeito, Judith Martins-Costa afirma que "[...] o art. 403 fixa certos limites à indenização: esta não pode abranger senão as perdas efetivas e os lucros que o credor deixou de realizar como consequência direta e imediata da inexecução. Resta, assim, afastado da indenização o damnum remotum bem como o dano meramente hipotético ou incerto". MARTINS-COSTA, Judith. Comentários ao novo Código Civil: do inadimplemento das obrigações. v. V. tomo 2. Rio de Janeiro: Forense. 2003. p. 337.

${ }^{675}$ Uma hipótese na qual se discute a "certeza de dano" é a teoria da perda de uma chance, sobre a qual se recomenda a leitura da seguinte obra: SAVI, Sergio. Responsabilidade civil por perda de uma chance. São Paulo: Atlas. 2006. 
Ademais, levando em consideração que no direito brasileiro vigora o princípio da reparação integral (artigo 944 do Código Civil ${ }^{676}$ ), o contratante lesado excepcionalmente terá direito à compensação do dano moral provocado pelo descumprimento, desde que reste comprovado que o inadimplemento lesou algum direito da personalidade naquele caso específico ${ }^{677}$.

Assim, qualquer que seja a solução adotada pelo credor (resolução do contrato ou cumprimento), sempre lhe será dado demandar a reparação pelos prejuízos causados pelo inadimplemento antecipado provocado pelo devedor. A indenização deverá contemplar todos os danos patrimoniais e extrapatrimoniais decorrentes diretamente da conduta do devedor que deu causa ao inadimplemento antecipado do contrato, abrangendo os danos emergentes e os lucros cessantes, assim como os interesses negativos e os interesses positivos da parte prejudicada pelo descumprimento ${ }^{678}$.

A título de exemplo, pode-se mencionar a situação em que a empresa " $A$ " pretende adquirir a totalidade das ações da sociedade " $\mathrm{X}$ " (subsidiária integral), controlada pela empresa "B". Nesse caso, as empresas celebraram um pré-contrato de compra e venda de ações, sem cláusula de arrependimento, definindo todos os seus termos e obrigações e estabelecendo um preço de compra que variaria entre $\mathrm{R} \$ 20.000 .000,00$ (vinte milhões) a $\mathrm{R} \$$ 50.000.000,00 (cinquenta milhões), a depender das conclusões de um relatório de auditoria a ser preparado e entregue em 90 (noventa) dias por uma grande empresa de auditoria contratada de comum acordo entre as partes.

\footnotetext{
676 “Art. 944. A indenização mede-se pela extensão do dano.”

${ }^{677}$ Ilustrativa dessa possibilidade é a decisão do Superior Tribunal de Justiça no sentido de que "conquanto geralmente nos contratos o mero inadimplemento não seja causa para ocorrência de danos morais, a jurisprudência desta Corte vem reconhecendo o direito ao ressarcimento dos danos morais advindos da injusta recusa de cobertura de seguro saúde, pois tal fato agrava a situação de aflição psicológica e de angústia no espírito do segurado, uma vez que, ao pedir a autorização da seguradora, já se encontra em situação de dor, de abalo psicológico e com a saúde debilitada". (STJ, AgRg no Resp 1.194.379/MS, $3^{\text {a }}$ Turma, Rel. Min. Sidnei Beneti, DJe 17.09.2010)

${ }^{678}$ Neste sentido, os princípios UNIDROIT relativos aos Contratos Comerciais Internacionais preveem que: “(1) A parte prejudicada tem direito ao ressarcimento integral pelos danos sofridos em razão do inadimplemento. Tais danos incluem tanto as perdas efetivamente sofridas quanto as vantagens que se deixaram de obter, levados em consideração quaisquer ganhos que a parte prejudicada haja obtido ao evitar gastos e danos. (2) Tais danos podem ser de natureza não pecuniária e incluem, por exemplo, o sofrimento físico ou moral" (artigo 7.4.2).
} 
No entanto, pouco mais de um mês após a assinatura do pré-contrato, a empresa "A" descobre que "B" alienou a totalidade das suas ações na sociedade "X" para um terceiro, o que caracteriza uma situação de inadimplemento antecipado. Nessa situação, além de pleitear a resolução do contrato, a empresa "A" poderá requerer a condenação de "B" ao pagamento de indenização a título de perdas e danos. A empresa "A" poderá pleitear o ressarcimento de todas as despesas incorridas na negociação e com a celebração do pré-contrato (exemplo: honorários de advogado, despesas com a realização da auditoria, passagens aéreas e estadias em hotéis dos seus representantes, etc.), além de todos os lucros que razoavelmente deixou de ganhar (o que, nesse caso específico, parece ser de difícil comprovação diante da vedação à indenização por danos hipotéticos).

É importante mencionar que o credor prejudicado pelo inadimplemento antecipado poderá pleitear a indenização pelos danos sofridos e requerer as demais medidas imediatamente, sem ter que esperar o transcurso do termo da obrigação inadimplida. A nosso ver, violaria a boa-fé objetiva exigir que o credor aguardasse o decurso do termo para poder pleitear a indenização, afinal foi o próprio devedor que provocou o inadimplemento antecipado, não podendo valer-se do benefício do termo para retardar o ressarcimento dos prejuízos que provocou ${ }^{679}$.

A imposição ao devedor do dever de reparar os danos não costuma suscitar maior controvérsia na doutrina, pois os autores geralmente admitem essa consequência. Contém, então, destacar algumas peculiaridades a serem consideradas quando da quantificação da indenização decorrente da quebra antecipada do contrato.

A quantificação do dano deverá se pautar pelas peculiaridades do caso concreto, considerando-se os danos emergentes e os lucros cessantes sofridos pela parte

\footnotetext{
${ }^{679}$ Neste mesmo sentido, Raphael Manhães Martins afirma que "este é o primeiro reflexo da configuração do inadimplemento antecipado. Afinal, o devedor que agiu de maneira desidiosa no cumprimento da obrigação ou recusa-se a cumpri-la não pode valer-se do benefício do termo para retardar o ressarcimento dos prejuízos que causou. Note-se que o reconhecimento desse dever de indenizar, trata, em última análise, de reduzir as perdas que a vítima do inadimplemento teve, seja evitando fazer novos gastos naquela relação, seja permitindo que ela tenha novamente recursos para contratar terceiros para concluir a execução do contrato". MARTINS, Raphael Manhães. Inadimplemento antecipado: perspectiva para a sua aplicação no direito brasileiro. Revista Forense, Rio de Janeiro, v. 391, ano 103, mai./jun. 2007, p. 220-221.
} 
lesada, bem como os seus interesses positivos e negativos. Como forma de auxiliar na obtenção do quantum indenizatório, Aline Terra aponta alguns elementos balizadores, tais como a publicidade conferida à declaração do devedor de não adimplir, o momento da configuração do inadimplemento antecipado nas obrigações a termo, além das medidas adotadas pelo credor para reduzir os danos ${ }^{680}$.

Com efeito, as circunstâncias relevadoras da situação de inadimplemento antecipado e o comportamento das partes contratantes assumem especial relevância na quantificação da indenização. Tratando-se de declaração de não querer ou de não poder adimplir, por exemplo, o prejuízo do credor normalmente dependerá da clareza e da maior ou menor publicidade conferida à manifestação do devedor ${ }^{681}$.

Caso o devedor declare de maneira transparente que não quer ou que não conseguirá adimplir no tempo, modo e lugar pactuados, fazendo com que isso chegue ao conhecimento do credor, maiores são as chances dele tomar as medidas necessárias para a proteção do seu direito de crédito e, consequentemente, diminuir o seu prejuízo. A boa-fé do devedor ao declarar, com clareza e publicidade, que inadimplirá a obrigação deverá ser prestigiada no momento da fixação do quantum indenizatório.

Também assume especial importância, sobretudo nas obrigações a termo essencial, o momento em que o inadimplemento resta configurado, a permitir, ou não, que o credor possa tomar alguma providência para satisfazer a prestação inadimplida. Assim, por exemplo, se uma empreiteira contratada para construir um prédio que sediará um grande evento esportivo, comunicar com seis meses de antecedência que não conseguirá entregá-lo na data pactuada, o contratante poderá contratar outra empreiteira para realizar parte da obra e acelerar a sua construção. Da mesma forma, o cantor que comunica que não irá se apresentar em uma determinada casa de shows causará menores prejuízos ao seu contratante se informá-lo com dois meses de antecedência, do que se fizer isso às vésperas

${ }^{680}$ TERRA, Aline de Miranda Valverde. Inadimplemento anterior ao termo. Rio de Janeiro: Renovar. 2009. p. 247.

681 TERRA, Aline de Miranda Valverde. Inadimplemento anterior ao termo. Rio de Janeiro: Renovar. 2009. p. 247. 
do espetáculo, quando não será mais possível sequer contratar outro músico para substituílo.

É de se recordar, igualmente, a incidência da teoria de mitigação dos danos (doctrine of mitigation). De acordo com a referida teoria, o credor que deixa de usar dos meios razoáveis para mitigar ou, pelo menos, não aumentar os danos que o devedor deverá ser condenado a pagar, não pode recobrar o equivalente àqueles danos evitáveis ${ }^{682}$. Assim, as ações e omissões praticadas pelo credor que sejam capazes de agravar os danos já sofridos não poderão remontar ao quantum indenizatório, pois o devedor não pode responder pelos danos causados pelo próprio credor $^{683}$. Ademais, todas as reduções de dano promovidas pelo credor devem ser abatidas do montante da indenização, porquanto a vítima deve ser indenizada, em regra, pelos danos efetivamente sofridos, sob pena de lhe proporcionar enriquecimento ilícito.

Com relação ao dever de mitigar os danos, Ruy Rosado Aguiar Júnior assevera que:

[...] deve ser lembrada a doutrina da mitigação (doctrine of mitigation), porquanto o credor deve colaborar, apesar da inexecução do contrato, de sorte que não agrave, pela sua ação ou pela sua omissão, o resultado danoso decorrente do incumprimento: "o lesado deve tomar todas as providências razoáveis para mitigar o dano e não pode pretender o ressarcimento da perda que teria podido evitar, mas que não evitou, por injustificada ação ou omissão. Essa doutrina dirigida para a avaliação do ressarcimento atua, também, na avaliação do prejuízo ao contrato resultante do incumprimento, tendo em vista a sua definição como sendo um incumprimento grave para o fim de resolução. Se a gravidade desse incumprimento decorreu da ação ou da omissão concorrente do credor, tal acréscimo não deve ser levado em consideração". ${ }^{6}{ }^{\circ}$

Imagine-se, por exemplo, uma empresa especializada na produção de pneus que contrata um seringueiro da Amazônia para que lhe entregue uma determinada

${ }^{682}$ AZULAY, Fortunato. Do inadimplemento antecipado do contrato. Rio de Janeiro: Editora Brasília/Rio. 1977. p. 120.

${ }^{683}$ Neste sentido, os princípios UNIDROIT relativos aos Contratos Comerciais Internacionais preveem que: “(1) A parte inadimplente não é responsável pela parte prejudicada na medida em que esses danos poderiam ter sido reduzidos com a adoção de medidas razoáveis por parte desta. (2) A parte prejudicada tem direito a reaver quaisquer despesas que tenha razoavelmente realizado na tentativa de reduzir os danos." (artigo 7.4.8) ${ }^{684}$ AGUIAR JÚNIOR, Ruy Rosado de. Extinção dos contratos por incumprimento do devedor. 2. Ed. Rio de Janeiro: AIDE. 1991. p.136. 
quantidade de látex para que possa produzir os pneus a que se comprometeu a vender para uma indústria automobilística. Se de duas semanas antes do termo ajustado para a entrega do látex, o seringueiro declarar que não adimplirá a sua prestação, a empresa especializada na produção de pneus, diante do inadimplemento antecipado, deve buscar outros fornecedores para minimizar seus danos. Caso ela se quede inerte, os danos decorrentes da sua omissão deverão ser abatidos do quantum indenizatório.

Diante do exposto, conclui-se que a parte prejudicada pelo inadimplemento antecipado fará jus ao recebimento de uma indenização pelas perdas e danos dele decorrentes, cujo quantum será fixado pelo juiz levando em conta as circunstâncias em que se deu o inadimplemento e o comportamento das partes contratantes à luz da boa-fé objetiva, especialmente com base nos critérios expostos acima. No entanto, além do ressarcimento das perdas e danos, sempre devido, o inadimplemento antecipado autoriza o credor a resolver o contrato ou pleitear o seu cumprimento, conforme a hipótese versada. É o que se passará a analisar a seguir.

\subsection{Resolução da relação contratual}

O inadimplemento absoluto confere ao credor o direito de requerer a resolução ${ }^{685}$ do contrato, extinguindo-se a relação jurídica mantida entre as partes, com a indenização dos danos que haja sofrido (artigo 389 do Código Civil) ${ }^{686}$. É o que dispõe o

\footnotetext{
${ }^{685}$ Para fins do presente trabalho, adotamos o conceito de resolução de Ruy Rosado de Aguiar Júnior: “a resolução é modo de extinção de relação obrigacional estabelecida em contrato bilateral, com retirada de sua eficácia pelo exercício do direito formativo extintivo, do qual é titular o credor não inadimplente, fundado no incumprimento definitivo e imputável do devedor. Excepcionalmente, a resolução pode ser de iniciativa deste, decorrer de incumprimento não imputável ou resultar de modificação das circunstâncias, invocável por ambas as partes." AGUIAR JÚNIOR, Ruy Rosado de. Extinção dos contratos por incumprimento do devedor. 2. ed. Rio de Janeiro: AIDE. 1991. p. 77). Araken de Assis também tem orientação semelhante: "o direito à resolução consiste no desfazimento da relação contratual, por decorrência de evento superveniente, ou seja, inadimplemento imputável, e busca a volta ao status quo. É um direito formativo extintivo e, porque dissolve o contrato, constitui exceção notória ao princípio da estabilidade do vínculo em virtude de fato adventício ao seu aperfeiçoamento." ASSIS, Araken de. Resolução do contrato por inadimplemento. 4. ed. rev. e atual. São Paulo: Editora Revista dos Tribunais. 2004. p. 77.

${ }^{686}$ Embora não seja objeto do presente estudo, é importante mencionar que, de acordo com a doutrina majoritária, são pressupostos para a resolução do contrato: (i) existência de um contrato bilateral ou sinalagmático, (ii) não inadimplência do credor que pleiteia a resolução do contrato; e (iii) que se esteja diante de uma hipótese de inadimplemento absoluto. Nesse sentido: AGUIAR JÚNIOR, Ruy Rosado de. Extinção dos contratos por incumprimento do devedor. 2. ed. Rio de Janeiro: AIDE. 1991. p. 87; GOMES, Orlando. Contratos. Rio de Janeiro: Forense. 2008. p. 84-85. Em sentido contrário, Araken de Assis entende
} 
artigo 475 do Código Civil: "a parte lesada pelo inadimplemento pode pedir a resolução do contrato, se não preferir exigir-lhe o cumprimento, cabendo, em qualquer dos casos, indenização por perdas e danos.",687

A resolução do contrato afigura-se como o exercício do direito formativo extintivo $^{688}$ franqueado ao credor diante do inadimplemento absoluto perpetrado pelo devedor $^{689}$, provocando alterações na esfera da eficácia do negócio jurídico: a extinção do contrato pela resolução tem o condão de promover o retorno das partes ao estado anterior à contratação, operando efeitos retroativos ${ }^{690}$.

Nas palavras de Pontes de Miranda, a resolução contratual é um "como se": como se o contrato nunca tivesse existido. Isso porque tal espécie extintiva, ao desconstituir o vínculo que ligava as partes contratantes, age para que as partes retornem ao estado das coisas existente antes da conclusão do contrato. Daí se afirmar que a

que a bilateralidade não é um requisito necessário para a resolução: “é um engano comum a automática conclusão de a técnica legislativa limitar ao contrato bilateral o domínio do instituto." Afirma que "a resolução supõe a interdependência de prestações" e que "o campo operativo da resolução se revela menor que o do inadimplemento das obrigações no contrato bilateral, pois nem todas se colocam em função recíproca, e, ao mesmo tempo, maior do que esta categoria abstrata, porque em outras avenças, unilaterais na aparência, se convencionou a resolução ou se criou, ainda que em parte acessória ou lateral, a bilateral, de resto imprescindível à aplicabilidade da resolução". ASSIS, Araken de. Resolução do Contrato por Inadimplemento. 4. ed. rev. e atual. São Paulo: Editora Revista dos Tribunais. 2004. p. 21 e p. 32.

${ }^{687}$ De acordo com a leitura clássica de Antunes Varela, se algum dos contratantes deixar de cumprir a prestação por fato que lhe seja imputável (ou porque a prestação se tornou impossível ou porque, com a demora do devedor, ela perdeu interesse para o credor), pode o outro requerer a resolução do contrato, extinguindo-se a relação obrigacional, com a indenização dos danos que haja sofrido. VARELA, João de Mattos Antunes. Das obrigações em geral. Coimbra: Almedina. 1970, p. 145.

${ }^{688}$ A esse respeito, Ruy Rosado de Aguiar Júnior afirma que "o exercício do direito formativo de resolução tem a função de extinguir a relação obrigacional e, com isso, liberar o credor da sua prestação [...]. Como a extinção atua para os dois lados, ela importa na liberação também do devedor. A extinção opera com retroatividade e normalmente traz consigo a necessidade de recomposição da situação assim como era antes, através da restituição e da reparação dos danos". AGUIAR JÚNIOR, Ruy Rosado de. Extinção dos contratos por incumprimento do devedor. 2. ed. Rio de Janeiro: AIDE. 1991. p. 47.

${ }^{689}$ Gabriel Rocha Furtado afirma que "[...] será pertinente resolver a relação contratual - em meio a outros casos - sempre que diante da mora do devedor a sua prestação não sirva mais ao alcance e concretização dos efeitos essenciais que sejam a causa do negócio; sempre, enfim, que esteja frustrada a finalidade do contrato". FURTADO, Gabriel Rocha. Mora e inadimplemento substancial. São Paulo: Atlas. 2014. p. 58.

${ }^{690}$ Ruy Rosado de Aguiar Júnior afirma que "além dos fatos supervenientes que extinguem a relação obrigacional, dando-lhe eficácia por algum modo de cumprimento, com ou sem satisfação do credor, ainda há os que surgem depois de celebrado o contrato e atingem a relação, retirando-lhe a eficácia. Esses atos, de destruição ou frustração da expectativa da plena realização do fim expresso no contrato, distinguem-se dos anteriores pela nota da ineficácia e entre eles se encontra a resolução. São fatos supervenientes que atuam no plano da simples ineficácia (resolução, revogação, distrato, denúncia, extinção ipso jure, arrependimento, prescrição)". AGUIAR JÚNIOR, Ruy Rosado de. Extinção dos contratos por incumprimento do devedor. 2. ed. Rio de Janeiro: AIDE. 1991. p.19. 
resolução do contrato faz com que se tenha "o negócio jurídico concluído como se concluído não tivesse sido"691.

O efeito retroativo da resolução, embora não seja previsto expressamente no artigo 475 do Código Civil, é indissociável do desfazimento dos vínculos obrigacionais, haja vista que é da essência da resolução a indenidade patrimonial do credor lesado. Daí a razão do emprego analógico do disposto no artigo 182 do Código Civil para regular as consequências da dissolução contratual ${ }^{692}$.

Assim, verificada qualquer das hipóteses de inadimplemento antecipado ${ }^{693}$ que sejam submetidas à égide do inadimplemento absoluto, a parte prejudicada poderá optar entre a resolução do contrato (extinção da relação jurídica e retorno das partes ao status $q u o^{694}$ ) e a indenização correspondente à prestação inadimplida, sendo-lhe sempre devida indenização por perdas e danos, nos termos do artigo 475 do Código Civil.

É indubitável que o inadimplemento antecipado confere ao credor o direito de resolver o contrato, afinal, não é admissível que, após uma das partes inadimplir antecipadamente a obrigação, acarretando a impossibilidade ou inutilidade da prestação

${ }^{691}$ PONTES DE MIRANDA, Francisco Cavalcanti. Tratado de direito privado. tomo XXV. São Paulo: Editora Revista dos Tribunais. p. 393.

${ }^{692}$ A esse respeito, Araken de Assis esclarece que "corolário natural e óbvio da extinção, assim produzida, consiste no retorno dos parceiros às posições ocupadas antes da contratação. É o que determina o art. 182 do CC-02 relativo à ação de nulidade, mas aplicável analogicamente ao remédio resolutivo, quando dispõe: 'restituir-se-ão as partes ao estado, em que antes dele se achavam, e não sendo possível restituí-las, serão indenizadas pelo equivalente"'. ASSIS, Araken de. Resolução do contrato por inadimplemento. 4. ed. rev. e atual. São Paulo: Editora Revista dos Tribunais. 2004. p. 260. Deliberando sobre hipótese específica, mas que denota a eficácia retroativa da resolução, o Superior Tribunal de Justiça afirmou que "a resolução do negócio jurídico firmado entre as partes implica a restituição dos contratantes ao estado anterior, consubstanciando, pois, mera consequência do desfazimento do contrato, a reintegração do bem ao arrendante e a restituição, ao arrendatário, dos valores pagos a título de VRG”. (STJ, AgRg no AI 864.576/SP, $4^{\text {a }}$ Turma, Rel. Min, Hélio Quaglia Barbosa, DJU 06.08.2007)

${ }^{693}$ Em virtude disso, se o devedor retarda ou omite ato necessário à execução da prestação devida, ou viola qualquer dever obrigacional, de modo a tornar impossível a prestação ou a impedir o seu cumprimento no termo ajustado, acarretando sua inutilidade para o sujeito ativo, o credor estará autorizado a resolver o contrato.

${ }^{694}$ Neste sentido: “corolário natural e óbvio da extinção, assim produzida, consiste no retorno dos parceiros às posições ocupadas antes da contratação. É o que delimita o art. 182 do CC-02 relativo à ação de nulidade, mas aplicável analogicamente ao remédio resolutivo, quando dispõe: restituir-se-ão as partes ao estado, em que antes dele se achavam, e não sendo possível restituí-las, serão indenizadas pelo equivalente". ASSIS, Araken de. Resolução do contrato por inadimplemento. 4. ed. rev. e atual. São Paulo: Editora Revista dos Tribunais. 2004. p. 145-146. 
devida, a outra ainda seja obrigada a agir como se tal fato não houvesse ocorrido e, portanto, cumprir o que fora avençado ${ }^{695}$.

É essa a orientação adotada por Cristiano de Sousa Zanetti, ao tratar do tema do inadimplemento antecipado:

[...] caso o descumprimento da obrigação principal seja certo, a parte lesada pode pleitear a resolução da relação jurídica contratual, bem como o pagamento das perdas e danos, exatamente conforme o previsto no art. 475 do Código Civil. A solução é a mesma se não forem observados deveres secundários, desde que essenciais ao cumprimento da prestação principal. Não custa recordar, porém, que a resolução não encontra lugar se o descumprimento for de pequena monta. ${ }^{696}$

Nesse sentido, a Convention on Contracts for the International Sales of Goods (Convenção de Viena Sobre Venda Internacional de Mercadoria), ao tratar do inadimplemento antecipado, prevê que "se antes da data do adimplemento tornar-se evidente que uma das partes incorrerá em violação essencial do contrato, poderá a outra parte declarar a rescisão" (artigo 72).

Os princípios UNIDROIT relativos aos Contratos Comerciais Internacionais também contêm previsão de que "uma parte poderá extinguir o contrato se, anteriormente ao termo de sua execução, resulta claro que haverá inadimplemento essencial pela outra parte" (artigo 7.3.3). Como se observa, a tendência no direito internacional é autorizar a resolução do contrato caso se configure uma hipótese de quebra antecipada.

\footnotetext{
695 Neste mesmo sentido, Raphael Manhães Martins afirma que "de nada adiantaria o direito de ser indenizado pelos prejuízos s o inadimplido ainda permanecesse obrigado a cumprir com a parte que lhe caberia no contrato. Surge como corolário necessário, portanto, que, em caso de inadimplemento antecipado, confira-se ao credor a possibilidade de acionar o mecanismo da resolução do contrato, conforme estabelecido no art. 475 do CC". MARTINS, Raphael Manhães. Inadimplemento antecipado: perspectiva para a sua aplicação no direito brasileiro. Revista Forense, Rio de Janeiro, v. 391, ano 103, mai./jun. 2007, p. 221.

696 ZANETTI, Cristiano de Souza. Inadimplemento Antecipado da Obrigação Contratual. In: CELLI JUNIOR, Umberto; BASSO, Maristela; AMARAL JÚNIOR, Alberto do (Coord). Arbitragem e comércio internacional: estudos em homenagem a Luiz Olavo Baptista. São Paulo: Quartier Latin. 2013. p. 324. Com a mesma orientação: "em nosso direito, seria curial a aplicação da doutrina do anticipatory breach através do art. 1092 do Código Civil (cláusula resolutiva tácita) quando o estado caracterizado de insolvência do devedor demonstrasse a quase, senão total, impossibilidade do cumprimento da prestação. Seria facultado ao credor, não só o direito de desobrigar-se do cumprimento da prestação que lhe caberia, como de demandar perdas e danos." AZULAY, Fortunato. Do inadimplemento antecipado do contrato. Rio de Janeiro: Editora Brasília/Rio. 1977. p. 115.
} 
Vale mencionar que a resolução pode ser classificada, quanto à fonte, em legal ou convencional ${ }^{697}$. A resolução legal é aquela que decorre da lei e se fundamenta na cláusula resolutiva tácita, que, segundo a doutrina, figuraria em todo contrato bilateral, em virtude da qual uma das partes pode exigir a resolução do contrato em razão do inadimplemento da outra ${ }^{698}$. A resolução convencional, por sua vez, é proveniente de cláusula resolutória expressa inserida no texto do contrato ou em instrumento anexo.

A importância desta classificação reside no fato de que, nos termos do artigo 474 do Código Civil ${ }^{699}$, a resolução do contrato com base na cláusula resolutiva tácita depende de sentença judicial que a declare e estabeleça os seus efeitos ${ }^{700}$; ao passo que, na cláusula resolutiva expressa, deixando o contratante de cumprir a obrigação na forma e no tempo ajustado, o contrato resolve-se automaticamente, sem necessidade de interpelação judicial $^{701}$.

Assim, considerando que o fundamento para a resolução nas hipóteses de inadimplemento antecipado também se encontra na cláusula resolutiva tácita ${ }^{702}$, salvo se as partes pactuarem cláusula resolutiva expressa, é necessária sentença judicial que declare que a parte está inadimplente e o contrato está resolvido, nos termos do artigo 474 do Código Civil. Na ação judicial, o juiz, chamado a examinar o inadimplemento antecipado,

\footnotetext{
${ }^{697}$ AGUIAR JÚNIOR, Ruy Rosado de. Extinção dos contratos por incumprimento do devedor. 2. ed. Rio de Janeiro: AIDE. 1991. p. 52.

${ }^{698}$ Caio Mário da Silva Pereira afirma que "os códigos modernos, no desenvolvimento da idéia, instituem o princípio que se denomina cláusula resolutiva tácita, imaginando-se que, em todo contrato bilateral, a sua inexecução por uma das partes tem como consequência facultar à outra promover a sua resolução, se não preferir a alternativa de reclamar a prestação, muito embora não tenham sido ajustadas estas consequências". PEREIRA, Caio Mario da Silva. Instituições de direito civil. v. III. Rio de Janeiro: Forense. 2006. p. 155.

699 “Art. 474. A cláusula resolutiva expressa opera de pleno direito; a tácita depende de interpelação judicial."

${ }^{700}$ Segundo Ruy Rosado de Aguiar Júnior, "a necessidade da intervenção judicial para a resolução do negócio dá à sentença a natureza constitutiva negativa e somente através dela é que se exerce e materializa o direito formativo do credor, pois é a sentença que resolve a obrigação. Nesse sistema, a atividade do juiz não se limita a declarar a resolução já acontecida por manifestação da vontade do credor, cumprindo-lhe verificar a presença dos pressupostos do direito formativo". AGUIAR JÚNIOR, Ruy Rosado de. Extinção dos contratos por incumprimento do devedor. 2. ed. Rio de Janeiro: AIDE. 1991. p. 55.

${ }^{701}$ PEREIRA, Caio Mario da Silva. Instituições de direito civil. v. III. Rio de Janeiro: Forense. 2006. p. 156158.

${ }^{702}$ AZULAY, Fortunato. Do inadimplemento antecipado do contrato. Rio de Janeiro: Editora Brasília/Rio. 1977. p. 53. No mesmo sentido: "o fundamento para a resolução também nas hipóteses de inadimplemento anterior ao termo se encontra na cláusula resolutiva tácita. Daí porque se exige a declaração judicial de que a parte está, de fato, inadimplente, e que, por isso, o contrato está resolvido.” TERRA, Aline de Miranda Valverde. Inadimplemento anterior ao termo. Rio de Janeiro: Renovar. 2009. p. 249.
} 
não se limita a declarar a existência do direito; ele desfaz o contrato e elimina os seus efeitos, retornando as partes ao status quo ${ }^{703}$.

Nessa demanda cabe ao credor o ônus de provar que o devedor inadimpliu o contrato antecipadamente, tornando a prestação devida impossível ou inútil, para pleitear a sua resolução. Isso porque, na pendência do termo, presume-se a inexigibilidade da prestação e, em tese, não haveria que se falar, ainda, em inadimplemento ${ }^{704}$. Desta feita, compete ao credor provar na ação judicial que o comportamento do devedor, por ação ou omissão, impossibilitou o cumprimento da prestação devida ou a tornou inútil.

É importante mencionar que a resolução opera no âmbito dos contratos bilaterais, nos quais o credor também está vinculado ao cumprimento de uma prestação. Assim, caso sobrevenha o inadimplemento antecipado sem que o credor tenha cumprido a sua prestação, ele pode se valer da "exceção de inseguridade" prevista no artigo 477 do Código Civil para suspender a sua prestação, antes mesmo do reconhecimento judicial do inadimplemento antecipado e da consequente resolução do contrato.

No entanto, a simples suspensão da prestação pode colocar o credor em situação de desvantagem se, ao final do processo judicial, não restar comprovado o inadimplemento antecipado do contrato. Nessa hipótese, o credor poderá ser considerado inadimplente caso a sua prestação, já sendo devida, não tenha sido adimplida em razão da referida suspensão (o que poderá acarretar uma situação de mora accipiendi ou de inadimplemento absoluto por fato imputável ao credor).

Portanto, caso sobrevenha o inadimplemento antecipado sem que o credor tenha cumprido a sua prestação, é fundamental que o credor deposite judicialmente a sua

\footnotetext{
${ }^{703}$ Confiram-se as lições de Ruy Rosado de Aguiar Júnior a respeito: “A necessidade de intervenção judicial para a resolução do negócio dá à sentença a natureza constitutiva negativa e somente com ela é que se materializa o direito formativo do credor, pois é a sentença que resolve a obrigação. Segundo esse sistema, a atividade do juiz não se limita a declarar a resolução já acontecida por manifestação da vontade do credor; mais que isso, cumpre-lhe verificar a presença dos pressupostos do direito formativo." AGUIAR JÚNIOR, Ruy Rosado de. Extinção dos contratos por incumprimento do devedor. 2. ed. Rio de Janeiro: AIDE. 1991. p. 56.

${ }^{704}$ TERRA, Aline de Miranda Valverde. Inadimplemento anterior ao termo. Rio de Janeiro: Renovar. 2009. p. 250.
} 
prestação antes de requerer a resolução do contrato, evitando-se a alegação de inadimplemento por sua parte. É a advertência formulada por Aline Terra:

\begin{abstract}
Sendo assim, o credor, diante de um provável inadimplemento anterior ao termo do devedor, e a fim de se resguardar de eventual alegação da contraparte de inadimplemento contratual, não deve simplesmente suspender sua pretensão, mas depositá-la judicialmente, por meio de medida cautelar inominada, até que o inadimplemento anterior ao termo seja reconhecido pelo juízo. ${ }^{705}$
\end{abstract}

Cumpre ponderar que, embora o instituto do inadimplemento antecipado vise simplificar a resolução contratual, evitando-se que o credor tenha que esperar até o termo do contrato para requerer a sua resolução por inadimplemento, a sua aplicação deve ocorrer com cautela, de maneira que nem toda declaração ou comportamento do devedor seja apto a gerar a resolução do contrato por inadimplemento antecipado, preservando-se os contratos e a sua função social, conforme preconiza o princípio da conservação dos negócios jurídicos ${ }^{706}$.

É necessário analisar com cuidado o comportamento do devedor, a satisfação dos requisitos para a configuração da quebra antecipada, bem como discutir qual é a consequência jurídica mais adequada para as partes e eventualmente terceiros interessados, se a resolução ou a propositura de uma ação de execução específica.

Em princípio, a resolução do contrato, por ser a medida mais drástica, deveria ser a consequência jurídica excepcional, sendo aplicável somente para os casos mais graves e incontornáveis, nos quais o inadimplemento antecipado tornou a prestação devida impossível ou inútil para o credor ${ }^{707}$.

705 TERRA, Aline de Miranda Valverde. Inadimplemento anterior ao termo. Rio de Janeiro: Renovar. 2009. p. 251.

${ }^{706}$ MARTINS. Guilherme Magalhães. Inadimplemento antecipado do contrato. Revista Trimestral de Direito Civil, Rio de Janeiro, v. 36, out/dez 2008, p. 85.

${ }^{707}$ A esse respeito, Gabriel Rocha Furtado afirma que "[...]) a resolução constitui medida extrema de extinção da relação contratual, colocando-se em direção antagônica ao fim inicialmente previsto e desejado pelas partes de que as obrigações fossem adimplidas e satisfeitos os respectivos credores. Daí se tratar de caminho excepcional no desenvolvimento da relação contratual, sendo admitida apenas nos casos previstos em lei e em que haja interesse legítimo e merecedor de tutela de quem a pleiteia”. FURTADO, Gabriel Rocha. Mora e inadimplemento substancial. São Paulo: Atlas. 2014. p. 23. 
Por sua vez, sempre que a prestação for ainda possível e útil, sendo este último juízo feito objetivamente, o direito preferirá que as partes contratantes busquem a execução específica da obrigação. Afinal, o adimplemento é o meio extintivo ideal da relação contratual, por ser dentre todas as hipóteses extintivas a que mais inteiramente satisfaz os interesses do credor.

Acrescente-se que a pretensão de resolução contratual deve passar por um cuidadoso processo de filtragem: muito embora o inadimplemento antecipado crie para a parte prejudicada o direito de resolução, seu exercício deve passar por uma análise do merecimento da tutela ${ }^{708}$, verificando-se a legitimidade do pleito do credor e a solução mais justa e adequada ao caso concreto à luz do princípio da boa-fé objetiva, da função social do contrato e dos novos paradigmas constitucionais ${ }^{709}$.

A teoria do adimplemento substancial não permite a resolução do vínculo contratual se houver cumprimento significativo, expressivo da prestação devida ${ }^{710}$. A referida teoria limita o exercício da resolução contratual sempre que, de um lado, houver um incumprimento insignificante das obrigações assumidas e, de outro lado, o

\footnotetext{
${ }^{708}$ Segundo Pietro Perlingieri, "não basta que o ato seja lícito, mas é necessário que ele, mesmo quando típico, seja merecedor de tutela naquele contexto particular (em consideração daqueles sujeitos, daquele momento, daquela cláusula acrescida, etc.)". PERLINGIERI, Pietro. $O$ direito civil na legalidade constitucional. Trad. de Maria Cristina De Cicco. Rio de Janeiro: Renovar. 2008. p. 370.

${ }^{709}$ Neste ponto, Gabriel Rocha Furtado assevera que, "sendo a resolução do contrato meio não satisfativo de extinção da relação jurídica formada entre os contratantes, a afastar por isso o processo obrigacional do seu curso (inicialmente planejado com vistas ao adimplemento), é preciso que o seu direito reflita um interesse merecedor de tutela por parte do credor. Na hipótese resolutória motivada pelo inadimplemento absoluto que é o objeto da presente investigação -, o interesse do credor que se diz frustrado não pode ser analisado isoladamente, devendo harmonizar-se com todos os interesses envolvidos no contrato e objetivamente sintetizados na função negocial - inclusive os do devedor e, numa perspectiva mais ampla e profunda, os sociais”. FURTADO, Gabriel Rocha. Mora e inadimplemento substancial. São Paulo: Atlas. 2014. p. 37. Em sentido semelhante: "[...]) a exigência de sentença judicial permite adequado controle na escolha efetuada pelo credor em utilizar-se da via resolutiva, onde joga importante papel (até hoje inaplicado, em nosso meio, convenientemente) o princípio da boa-fé e suas derivações, com o fim de cercear o uso incorreto do direito de extinção." AGUIAR JÚNIOR, Ruy Rosado de. Extinção dos contratos por incumprimento do devedor. 2. ed. Rio de Janeiro: AIDE. 1991. p. 51.

${ }^{710}$ Gustavo Tepedino afirma que a teoria do adimplemento substancial "veda ao credor o exercício do direito de rescisão do contrato, ainda quando a norma contratual ou legal a preveja, se a prestação pactuada foi substancialmente satisfeita pelo devedor". TEPEDINO, Gustavo; BARBOZA, Heloisa Helena; MORAES, Maria Celina Bodin de. Código Civil interpretado conforme a Constituição da República. v. I, 2. ed. rev. e atual. Rio de Janeiro: Renovar. 2007. p. 697.
} 
descumprimento de um dever obrigacional não alterar o sinalagma do contrato, a sua finalidade econômico-social, o interesse do credor e o resultado útil programado ${ }^{711}$.

Ademais, a função restritiva da boa-fé objetiva impõe que o direito à resolução não pode ser exercido arbitrariamente, assim como todas as situações jurídicas subjetivas, mas apenas dentro dos limites funcionais que justificam sua previsão pelo ordenamento jurídico e a tornam merecedora de tutela ${ }^{712}$.

Daí concluir-se que, no atual estágio do direito obrigacional, o direito de resolver antecipadamente o contrato deve ser aplicado com cautela, verificando o comportamento das partes à luz da boa-fé objetiva e se a prestação devida se tornou impossível ou inútil para o credor.

\subsection{Demanda de Cumprimento}

Configurado o inadimplemento absoluto ou a mora, o credor pode, imediatamente, ajuizar ação visando ao cumprimento da obrigação. Nas palavras de Araken de Assis, a demanda de cumprimento "representa o exercício da pretensão à prestação, através do qual o contratante lesado reclama in natura ou pelo equivalente pecuniário, e terá natureza condenatória ou executiva"713.

Nos casos em que o inadimplemento antecipado configurar-se como inadimplemento absoluto, caberá ao credor pleitear a resolução do contrato ou exigir o cumprimento da obrigação por meio da tutela pelo equivalente, nos termos do artigo 475

\footnotetext{
${ }^{711}$ Sobre a questão, Cristiano de Souza Zanetti afirma que se deve " $[\ldots .$.$] prestar máxima atenção a eventual$ cláusula resolutiva expressa. De acordo com o art. 474 do Código Civil, a inserção da referida cláusula serve precisamente para que a parte possa dar por resolvida a relação, caso reste verificado o inadimplemento nela previsto. Não há necessidade, por conseguinte, de discutir a relevância da obrigação contratual descumprida, dado que as partes já terão reputado suficiente para pôr fim ao negócio. De nada importa que, sob o ponto de vista de terceiro, o descumprimento possa ser considerado de maior ou menor importância". ZANETTI, Cristiano de Souza. Inadimplemento Antecipado da Obrigação Contratual. In: CELLI JUNIOR, Umberto; BASSO, Maristela; AMARAL JÚNIOR, Alberto do (Coord). Arbitragem e comércio internacional: estudos em homenagem a Luiz Olavo Baptista. São Paulo: Quartier Latin. 2013. p. 325.

${ }_{712}^{712}$ FURTADO, Gabriel Rocha. Mora e inadimplemento substancial. São Paulo: Atlas. 2014. p. 44.

${ }^{713}$ ASSIS, Araken de. Resolução do contrato por inadimplemento. 4. ed. rev. e atual. São Paulo: Editora Revista dos Tribunais. 2004. p. 36.
} 
do Código Civil. Vale destacar que somente é possível a execução através da tutela pelo equivalente, uma vez que o inadimplemento absoluto destitui a utilidade da prestação, seja pela impossibilidade de cumprimento da prestação, seja pela perda do interesse do credor. Haverá tutela ressarcitória pelo valor equivalente à prestação devida.

Nos casos em que o inadimplemento antecipado enquadrar-se como mora, será permitido ao credor dar cumprimento ao contrato. Para atingir tal objetivo, surge o mecanismo da tutela específica ${ }^{714}$, que busca dar ao credor exatamente aquilo que ele obteria se o devedor tivesse cumprido espontaneamente a obrigação que lhe cabia. Esta é a disciplina conferida pelos artigos 461 e 461-A do Código de Processo Civil, segundo os quais o juiz poderá estabelecer prazo para que o devedor cumpra a prestação devida, cabendo-lhe fixar multa diária, entre outras medidas, como forma de coação indireta sobre o devedor.

De acordo com a redação do artigo 461 do Código de Processo Civil, "na ação que tenha por objeto o cumprimento da obrigação de fazer ou não fazer, o juiz concederá a tutela específica da obrigação ou, se procedente o pedido, determinará providências que assegurem o resultado prático equivalente ao do cumprimento". Esse dispositivo legal, trazido pela reforma legislativa de 1994, veio deixar clara a opção do legislador de privilegiar a tutela específica da obrigação de fazer ou de não fazer, seja ela legal ou contratual, fungível ou infungível ${ }^{715}$.

Nas palavras de Fredie Didier, o artigo 461 do Código de Processo Civil prevê o que "passou a ser chamado de princípio da primazia da tutela específica das obrigações

\footnotetext{
${ }^{714}$ Fredie Didier afirma que "a importância de distinguir entre inadimplemento absoluto e inadimplemento relativo está em que, se o objeto da prestação for um fazer, não fazer ou dar coisa distinta de dinheiro e ainda houver possibilidade/utilidade de cumprimento da prestação, o credor tem o direito subjetivo a que esse cumprimento se dê de forma específica (art. 461, CPC). Em outras palavras, pode ele, credor, manejar execução buscando alcançar o próprio fazer, não fazer ou a coisa pretendida. Assim, somente o inadimplemento absoluto ou a vontade do credor podem dar ensejo à conversão dessas prestações em perdas e danos (art. 461, $\S 1^{\circ}$, CPC).” DIDIER JR., Fredie; CUNHA, Leonardo Carneiro da; BRAGA, Paula Sarno; OLIVEIRA, Rafael Alexandria de. Curso de Direito Processual Civil 5. 6. ed. Salvador: Editora JusPodivm. 2014. p. 92.

${ }^{715}$ Importante observar que a modificação do art. 461 do CPC pela Lei ${ }^{\circ} 10.444 / 2002$ estendeu às obrigações de dar coisa distinta de dinheiro a mesma forma de efetivação das obrigações de fazer e não fazer, concedendo ao magistrado um poder geral de impor a medida coercitiva que mais se adequasse à tutela do bem da vida em disputa.
} 
de fazer e de não fazer, segundo o qual se deve buscar dar ao credor tudo aquilo e exatamente aquilo que ele obteria se o devedor tivesse cumprido espontaneamente a obrigação que lhe cabia" 716 .

Verifica-se que, no sistema atual, a regra é a tutela específica ${ }^{717}$; a obrigação imposta ao devedor somente será convertida em obrigação pecuniária (i) se o credor optar por esta conversão; ou (ii) se não for possível a obtenção da tutela específica ou do resultado prático equivalente, nos termos do artigo 461, § $1^{\circ}$, do Código de Processo Civil $^{718}$.

Assim, nas situações concretas em que o inadimplemento antecipado enquadrar-se como mora, o juiz pode e deve compelir o devedor de obrigação de fazer, não fazer e dar coisa certa a cumpri-la mediante a cominação de multa (astreinte), que deverá incidir até o integral cumprimento da obrigação, ou outras medidas coativas, consoante autorizam os artigos 461 e 461-A do Código de Processo Civil.

Para ilustrar, pode-se cogitar do caso em que um determinado clube de futebol contratou um jogador, que deveria se apresentar para a comissão técnica do time dentro de 30 (trinta) dias; todavia, antes desse prazo, o agente do jogador anuncia para a imprensa que ele decidiu romper o contrato e assinar com outro time. Diante dessa situação de inadimplemento antecipado, o clube de futebol preterido poderá ajuizar demanda de

716 DIDIER JR., Fredie; CUNHA, Leonardo Carneiro da; BRAGA, Paula Sarno; OLIVEIRA, Rafael Alexandria de. Curso de Direito Processual Civil 5. 6. ed. Salvador: Editora JusPodivm. 2014. p. 425.

${ }_{717}$ Paulo Lôbo afirma que "a evolução do direito brasileiro, diferentemente do que prevaleceu até recentemente, aponta para remeter a indenização por perdas e danos, em virtude do inadimplemento da obrigação de fazer, para a última opção. Nesse sentido são o Código de Defesa do Consumidor e o Código de Processo Civil, para que o juiz priorize a execução específica, ou a obtenção do resultado prático correspondente, reforçando-se não propriamente a posição do credor, mas o interesse merecedor de tutela veiculado por tais espécies de obrigações”. LÔBO, Paulo. Direito civil: obrigações. 3. ed. São Paulo: Saraiva. 2013. p. 107.

${ }^{718}$ A respeito da questão, Gustavo Tepedino afirma que "o CC, sem se afastar dessa tendência, sobretudo quando interpretado sistematicamente, prevê a conversão das obrigações de fazer em perdas e danos, em casos em que, numa ponderação previa dos valores em cotejo, não convém a execução específica; seja em favor da dignidade da pessoa humana, preservando-se - a despeito da tendência acima indicada - a inviolabilidade da esfera pessoal do devedor para fins de execução de um dever patrimonial; seja para a preservação de interesses de terceiros de boa-fé; seja pela dificuldade que, em certas hipóteses poderia representar a execução coativa, em sacrifício da celeridade de uma prestação jurisdicional compensatória". TEPEDINO, Gustavo; SCHREIBER, Anderson. In: AZEVEDO, Álvaro Villaça (Coord.). Código Civil comentado: direito das obrigações. São Paulo: Atlas. 2008. p. 518. 
cumprimento requerendo que o jogador se apresente imediatamente para a sua comissão técnica, sob pena de incidência de multa diária.

Vale também mencionar a situação hipotética em que "A", empresa sediada na Rússia, contrata "B", agricultor residente no Brasil, para lhe entregar 10.000 (dez mil) sacas de grãos de café em certa data, as quais devem ser remetidas por navio com um prazo de antecedência de dez dias para que possa chegar no seu destino dentro do prazo pactuado. Caso a empresa "A" constate que "B" não remeteu a mercadoria com a antecedência mínima de dez dias, poderá ajuizar demanda de cumprimento requerendo que “B” despache por navio, imediatamente, as 10.000 (dez mil) sacas de grãos de café, sob pena da incidência de multa diária.

Nas obrigações que demandem a realização de atos preparatórios, como a obtenção de alguma licença ou autorização governamental, ou a realização de alguma obra específica e prévia, é possível vislumbrar a execução específica para determinar que o devedor pratique tais atos no prazo estabelecido pelo juiz, sob pena da incidência de multa cominatória e demais medidas coercitivas previstas em lei, para viabilizar o cumprimento da prestação devida no termo pactuado.

Finalmente, é possível a aplicação dos artigos $249^{719}$ e $251^{720}$ do Código Civil, para os casos de inadimplemento antecipado. Assim, ocorrendo o inadimplemento, o credor poderá contratar com terceiros a realização da prestação devida, cabendo ao devedor original reembolsar os valores despendidos com a contratação do terceiro e arcar com os prejuízos decorrentes de tal medida, como, por exemplo, o custo da contratação em caráter emergencial, ou mesmo, os custos com a negociação e elaboração do novo contrato.

\footnotetext{
719 “Art. 249. Se o fato puder ser executado por terceiro, será livre ao credor mandá-lo executar à custa do devedor, havendo recusa ou mora deste, sem prejuízo da indenização cabível.

Parágrafo único. Em caso de urgência, pode o credor, independentemente de autorização judicial, executar ou mandar executar o fato, sendo depois ressarcido."

720 “Art. 251. Praticado pelo devedor o ato, a cuja abstenção se obrigara, o credor pode exigir dele que o desfaça, sob pena de se desfazer à sua custa, ressarcindo o culpado perdas e danos.

Parágrafo único. Em caso de urgência, poderá o credor desfazer ou mandar desfazer, independentemente de autorização judicial, sem prejuízo do ressarcimento devido.”
} 
Frise-se que não haverá nenhum óbice para a imediata propositura da demanda de cumprimento, uma vez que o termo contratual é desconsiderado em razão da conduta do devedor que acarretou o inadimplemento antecipado do contrato. A perda do benefício do termo implica na imediata exigibilidade da obrigação, o que autoriza a demanda de cumprimento $^{721}$.

Assim, demonstrado o inadimplemento absoluto ou a mora, impõe-se que o juiz determine ao devedor a execução da prestação devida (ou a prestação que lhe seja equivalente, conforme o caso) imediatamente, tendo em vista a desconsideração do termo. Obviamente, se a execução da prestação demandar certo lapso de tempo, o juiz deve conceder ao devedor prazo compatível com o vulto e a complexidade da prestação. Aplicase, portanto, a regra geral a respeito do tempo do pagamento, descrita por Orosimbo Nonato:

\begin{abstract}
Entretanto, o imediato pagamento nas obrigações sem prazo deve ser entendido em termos e constitui princípio suscetível de temperamentos e mitigações. (...) O rigor do princípio - in omnibus obligationis in quibus dies non ponitur die praesenti debetur - é atemperado por exceções impostas da necessidade e por equidade, a que a lei se acurva. Eis por que Alves Moreira o enuncia por esta forma: a prestação terá de ser feita quando o credor a exigir, salvo o lapso de tempo dependente da natureza do contrato. ${ }^{722}$
\end{abstract}

Pense-se, por exemplo, na compra de um equipamento médico importado, em que o vendedor se compromete a importá-lo e a entregá-lo ao comprador em quatro meses, afirmando que nesse prazo se incluem as licenças e autorizações governamentais necessárias para introduzir o equipamento licitamente no Brasil. Se, ao final do segundo

721 Neste sentido: "na demanda de cumprimento decorrente de inadimplemento anterior ao termo, por sua vez, embora, de fato, ainda não se tenha verificado o termo, a já configurada violação da prestação devida importa a perda de merecimento de tutela do benefício conferido ao devedor, a tornar a prestação desde logo exigível. Além de já existir o crédito e o débito, existe também a pretensão ao seu recebimento, a autorizar o ajuizamento de demanda com vistas ao cumprimento imediato da prestação". TERRA, Aline de Miranda Valverde. Inadimplemento anterior ao termo. Rio de Janeiro: Renovar. 2009. p. 252. Vale mencionar a ponderação realizada por Raphael Manhães Martins, que, se olvidando da funcionalização do termo e da consequente perda do benefício por ele conferido, indica que a pendência do termo surge como entrave para a execução específica: “[...] deve ser reconhecido, entretanto, que a execução específica sofre limitações, pelo fato de não haver ainda o vencimento antecipado da dívida, demandando do intérprete (e, principalmente, do juiz) uma certa parcimônia em sua aplicação". MARTINS, Raphael Manhães. Inadimplemento antecipado: perspectiva para a sua aplicação no Direito brasileiro. Revista Forense, Rio de Janeiro, v. 391, ano 103, mai./jun. 2007, p. 186.

${ }^{722}$ NONATO, Orosimbo. Curso de Obrigações. v. I. Rio de Janeiro: Forense. 1959. p. 264. 
mês, o importador informa ao credor que não entregará o equipamento, o prazo concedido à importadora perde a sua razão de existir, e a prestação passa a ser, imediatamente, exigível. Configura-se, então, apenas a mora do devedor, já que a prestação conserva o seu interesse e a sua utilidade para o credor. Diante de tal situação, o comprador pode ajuizar demanda de cumprimento a fim de exigir que a importadora lhe forneça o equipamento de imediato. Nesse caso, o juiz deverá conceder prazo para a execução da prestação compatível com o necessário para a sua importação e, após o decurso desse prazo, incidirá a multa cominatória.

\subsection{Efeitos do risco de descumprimento (“exceção de inseguridade")}

$\mathrm{O}$ risco de descumprimento, que não se confunde com o inadimplemento antecipado, por se tratar apenas de probabilidade (alta probabilidade), e não de configuração de inadimplemento (probabilidade próxima à certeza), acarreta efeitos diversos daqueles anteriormente examinados. Embora o objeto da presente dissertação seja o exame do inadimplemento antecipado, é importante analisar os efeitos do risco de inadimplemento para melhor diferenciar os institutos e as suas consequências jurídicas.

Como analisado nos capítulos anteriores, o termo representa o momento em que a prestação devida deve ser entregue e, portanto, em regra, o momento a partir do qual o credor pode exigir a prestação. Todavia, isso não significa que o credor não possa proteger seu direito de crédito diante de uma situação que coloque em grave risco o adimplemento da obrigação. Apesar de ainda inexigível, o crédito já existe, motivo pelo qual o ordenamento coloca à disposição do credor mecanismos de tutela ${ }^{723}$.

O ordenamento jurídico permite que o credor pratique os atos conservatórios necessários para impedir a perda ou deterioração do seu direito. É o que se extraí da leitura combinada dos artigos 130 e 135 do Código Civil ${ }^{724}$. Isso porque o termo não atinge a

\footnotetext{
723 TERRA, Aline de Miranda Valverde. Inadimplemento anterior ao termo. Rio de Janeiro: Renovar. 2009. p. 256

724 “Art. 130. Ao titular do direito eventual, nos casos de condição suspensiva ou resolutiva, é permitido praticar os atos destinados a conservá-lo."
} 
existência da obrigação, mas apenas a sua execução (plano da eficácia). Assim, enquanto a obrigação não se torna exigível, o credor poderá praticar os atos de conservação do seu direito $^{725}$.

Diante do risco de descumprimento provocado pela deterioração da situação patrimonial do devedor ou do comportamento do devedor (conforme visão ampliativa que adotamos) capaz de, com alta probabilidade, comprometer ou tornar duvidosa a prestação à qual se obrigou, o artigo 477 Código Civil possibilita ao credor, nos contratos bilaterais ou sinalagmáticos, se valer da "exceção de inseguridade", suspendendo a prestação que lhe incumbe até que o devedor satisfaça a sua contraprestação ou dê garantia bastante para satisfazê-la ${ }^{726}$.

Frise-se que é necessário apurar, diante da situação concreta, se é um caso de inadimplemento antecipado ou de risco de descumprimento (conforme critérios definidos no capítulo 2), para se identificar qual é a consequência jurídica adequada. Em princípio, a resolução ficaria reservada àqueles casos em que o cumprimento da obrigação no vencimento futuro se afigurasse, com probabilidade próxima à certeza, impossível ou extremamente difícil. Nesta hipótese, o inadimplemento antecipado conferiria ao credor a possibilidade de resolver o contrato com fundamento no artigo 475 do Código Civil, podendo o interessado, ainda, optar pela execução específica da obrigação, nos termos dos artigos 461 e 461-A do Código de Processo Civil.

Por sua vez, nas situações de risco de descumprimento, em que há uma alta probabilidade de inadimplemento pelo devedor, seriam aplicáveis as consequências jurídicas previstas no artigo 477 do Código Civil, as quais têm a vantagem de substituir a

“Art. 135. Ao termo inicial e final aplicam-se, no que couber, as disposições relativas à condição suspensiva e resolutiva."

${ }^{725}$ NONATO, Orosimbo. Curso de obrigações. v. I. Rio de Janeiro: Forense. 1959. p. 257.

${ }^{726}$ Conforme destaca Pontes de Miranda, no atual artigo 477 do Código Civil não se trata de "pretensão à prestação antecipada (em relação à do outro figurante) ou à caução. Trata-se de exceção. Ao outro figurante é que cabe escolher entre prestar antecipadamente (= ao mesmo tempo em que teria que prestar antes), ou dar caução". E conclui: "se a caução não pode ser prestada, nem há meios para o credor adimplir, o devedor, que teria de prestar antes, tem de esperar que se vença a dívida do outro figurante, para poder pedir a resolução por inadimplemento". MIRANDA, Pontes de. Tratado de direito privado. t. XXVI, Rio de Janeiro: Editor Borsoi. 1959. p. 109-110. 
resolução por um remédio menos severo e mais compatível com a situação de incerteza que pende sobre o cumprimento da obrigação, autorizando o contratante a recusar-se à prestação que lhe compete, até que a outra parte satisfaça a que lhe incumbe ou dê garantia bastante para fazê-la.

Esse também é o posicionamento adotado por Anderson Schreiber, consoante se verifica abaixo:

[...] A resolução ficaria, deste modo, reservada àqueles casos em que o cumprimento da obrigação no vencimento futuro se afigurasse, desde já, impossível (e.g., construção do hospital em quinze dias); enquanto que, na mera improbabilidade do cumprimento (construção do hospital em seis meses), o efeito seria a não resolução, mas a aplicação, por analogia, do disposto no art. 477 do Código Civil. ${ }^{727}$

Saliente-se, todavia, que a adoção da medida prevista no artigo 477 do Código Civil exige a precisa configuração do risco de descumprimento, haja vista que a suspensão da prestação em contratos bilaterais é medida extremamente dura para a outra parte. Sendo assim, é possível que a suspensão acabe por inviabilizar o adimplemento pela contraparte. É o que aconteceria, por exemplo, se todos os adquirentes de unidades autônomas de empreendimento em construção resolvessem suspender o pagamento de suas prestações, em razão de um risco não comprovado de descumprimento.

A nosso ver, à luz da função social do contrato e do princípio da boa-fé objetiva, o reconhecimento da possibilidade de suspensão da prestação não se subordina apenas à configuração do risco de descumprimento, mas depende de uma ponderação dos interesses envolvidos na relação obrigacional e das consequências do reconhecimento (ou não) do risco de descumprimento para as partes e para terceiros.

\subsection{Cláusula Penal}

727 SCHREIBER, Anderson. A tríplice transformação do adimplemento. Adimplemento substancial, inadimplemento antecipado e outras figuras. Revista Trimestral de Direito Civil, Rio de Janeiro, v. 32, out./dez 2007, p. 13. 
A cláusula penal consiste em um pacto acessório pelo qual as partes fixam previamente a indenização devida em caso de descumprimento total da obrigação (cláusula penal compensatória) ou, ainda, em caso de descumprimento de determinada cláusula do contrato ou de mora (cláusula penal moratória) ${ }^{728}$. No contrato, não há cláusula penal sem acordo ou consentimento das partes ${ }^{729}$.

Trata-se de uma obrigação acessória que objetiva garantir o cumprimento da obrigação, bem como fixar, antecipadamente, o valor das perdas e danos para a hipótese de inadimplemento. De acordo com a melhor doutrina ${ }^{730}$, a cláusula penal tem basicamente duas finalidades: (i) funciona como uma coerção, para intimidar o devedor a cumprir a sua prestação, sob pena de ter que arcar com essa obrigação acessória; e (ii) prefixa as perdas e danos no caso de inadimplemento da obrigação ${ }^{731}$.

Destaca-se a importância da cláusula penal como instrumento de segurança das relações obrigacionais na sociedade moderna, reforçando o vínculo contratual, especialmente nos momentos de crise econômica, nos quais cresce o temor de inadimplência dos contratos. Nas palavras de Arnaldo Rizzardo, "quanto maiores as instabilidades de uma economia e mais fortes as crises que assolam os povos, ou menos evoluída a consciência moral das pessoas, geralmente mais cresce a inadimplência das

\footnotetext{
728 Neste sentido, o seguinte dispositivo do Código Civil: “Art. 409. A cláusula penal estipulada conjuntamente com a obrigação, ou em ato posterior, pode referir-se à inexecução completa da obrigação, à de alguma cláusula especial ou simplesmente à mora". Segundo Carlos Roberto Gonçalves: "cláusula penal é obrigação acessória, pela qual se estipula pena ou multa destinada a evitar o inadimplemento da principal, ou o retardamento do seu cumprimento. É também denominada pena convencional ou multa contratual. Adaptase aos contratos em geral e pode ser inserida, também, em negócios jurídicos unilaterais, como o testamento, para compelir, por exemplo, o herdeiro a cumprir fielmente o legado" (GONÇALVES, Carlos Roberto. Direito civil brasileiro, vol. 2: teoria geral das obrigações. 8. ed. São Paulo: Saraiva, 2011. p. 411).

${ }^{729}$ LÔBO, Paulo. Direito civil: obrigações. 3. ed. São Paulo: Saraiva, 2013. p. 267. Importante observar que o Superior Tribunal de Justiça já decidiu que "a cláusula penal contida nos contratos bilaterais, onerosos e comutativos deve aplicar-se para ambos os contratantes indistintamente, ainda que redigida apenas em favor de uma das partes” (STJ, REsp 1119740, Rel. Min, Massami Uyeda, j. 27.09.2011).

${ }^{730}$ PEREIRA, Caio Mário da Silva. Instituições de Direito Civil. vol. II. 20. ed. Rio de Janeiro: Forense, 2005. p. 145-146.

${ }^{731}$ A respeito da questão, Gustavo Tepedino afirma que “(...) os fundamentos da cláusula penal, a despeito da discussão doutrinária sobre sua finalidade precípua, são o de servir de instrumento de pré-fixação das perdas e danos e, simultaneamente, elemento de reforço do liame contratual" (TEPEDINO, Gustavo. BARBOZA, Heloisa Helena. MORAES, Maria Celina Bodin de. Código Civil Interpretado Conforme a Constituição da República. Vol. I, 2. ed. rev. e atual., Rio de Janeiro: Renovar, 2007. p. 749).
} 
obrigações, ensejando mecanismos de defesa e proteção dos direitos e créditos emanados das convenções e contratos", 732

A cláusula penal é classificada em moratória ou compensatória de acordo com aquilo com que mantém relação. A cláusula penal moratória é estipulada para desestimular o devedor de incorrer em mora ou para evitar que deixe de cumprir determinada cláusula especial. Por exemplo, em uma promessa de compra e venda de um apartamento, é estipulada multa para o caso de atraso na entrega.

Já a cláusula penal compensatória é prevista para servir como indenização no caso de total inadimplemento da obrigação principal (adimplemento absoluto). Funciona como uma prefixação das perdas e danos. A convenção do contrato que prevê a cláusula penal pressupõe a existência do prejuízo decorrente do inadimplemento e prefixa o seu valor. Assim, basta ao credor demonstrar o inadimplemento, ficando dispensado da prova do prejuízo $^{733}$. Por exemplo, em um contrato para que um cantor faça um show no réveillon, é estipulada uma multa de cem mil reais caso ele não se apresente.

A importância da distinção entre ambas as espécies se dá na medida em que, dependendo do tipo de cláusula penal, os efeitos que irão gerar serão distintos. A cláusula penal moratória é cumulativa ${ }^{734}$, ou seja, o credor poderá exigir o cumprimento da obrigação principal, a multa contratualmente estipulada e, ainda, a indenização correspondente às perdas e danos decorrentes da mora ${ }^{735}$. Exemplo: o promitente comprador, no caso de atraso na entrega do imóvel adquirido, tem direito a exigir, além do

\footnotetext{
${ }^{732}$ RIZZARDO, Arnaldo. Direito das obrigações. Rio de Janeiro: Forense, 1999. p. 251.

733 Caio Mário da Silva Pereira afirma que "o efeito fundamental da pena convencional, e que pode ser assinalado como determinação cardeal, é a sua exigibilidade pleno iure (Código Civil de 2002, art. 408), no sentido de que independe da indagação se o credor foi o não prejudicado pela inexecução do obrigado" (PEREIRA, Caio Mário da Silva. Instituições de Direito Civil. vol. II. 20. ed. Rio de Janeiro: Forense, 2005. p. 156).

734 “Art. 411. Quando se estipular a cláusula penal para o caso de mora, ou em segurança especial de outra cláusula determinada, terá o credor o arbítrio de exigir a satisfação da pena cominada, juntamente com o desempenho da obrigação principal".

${ }^{735}$ Neste sentido, o Superior Tribunal de Justiça afirmou que "o promitente comprador, em caso de atraso na entrega do imóvel adquirido pode pleitear, por isso, além da multa moratória expressamente estabelecida no contrato, também o cumprimento, mesmo que tardio da obrigação e ainda a indenização correspondente aos lucros cessantes pela não fruição do imóvel durante o período da mora da promitente vendedora" (STJ, REsp 1.355.554-RJ, Rel. Min. Sidnei Beneti, j. 6/12/2012).
} 
cumprimento da obrigação e do pagamento do valor da cláusula penal moratória, a indenização correspondente aos lucros cessantes pela não fruição do imóvel durante o período da mora. (ex: se o adquirente comprovar que adquiriu o apartamento para alugálo).

A cláusula penal compensatória, por sua vez, não é cumulativa. Assim, haverá uma alternativa para o credor: exigir o cumprimento da obrigação principal ou apenas o valor da cláusula penal ${ }^{736}$. Como regra geral não é possível a cumulação da cláusula penal com pedido de indenização, porque a cláusula penal compensatória já substituiu a indenização pelas perdas e danos ${ }^{737}$. No entanto, se no contrato estiver expressamente prevista esta possibilidade de cumulação, a multa funciona como valor mínimo de indenização, cabendo ao credor provar o prejuízo excedente para fazer jus à indenização complementar $^{738}$ (artigo 416, parágrafo único, do Código Civil ${ }^{739}$ ).

Para a cláusula penal (moratória ou compensatória) se tornar eficaz, o artigo 408 do Código Civil ${ }^{740}$ estabelece que basta a materialidade do inadimplemento ou a configuração da mora do devedor. Vale mencionar que o legislador incluiu, no referido dispositivo, a expressão "culposamente", o que poderia sugerir a imposição de um requisito subjetivo para a incidência da cláusula penal. Tal conclusão, contudo, deve ser afastada interpretativamente, "em homenagem à coerência do sistema"741.

\footnotetext{
736 “Art. 410. Quando se estipular a cláusula penal para o caso de total inadimplemento da obrigação, esta converter-se-á em alternativa a benefício do credor".

${ }^{737}$ Vale mencionar o polêmico enunciado 430 da V Jornada de Direito Civil sobre a aplicação do artigo 416, $\S$ único, do Código Civil, aos contratos de adesão: "No contrato de adesão, o prejuízo comprovado do aderente que exceder ao previsto na cláusula penal compensatória poderá ser exigido pelo credor, independentemente de convenção".

${ }^{738}$ Sobre a questão, o Tribunal de Justiça do Estado de São Paulo decidiu que, "ainda que o prejuízo exceda ao previsto na cláusula penal [compensatória], não pode o credor exigir indenização suplementar se assim não tiver sido convencionado." (TJSP, Apelação n $n^{\circ}$ 0023528-84.2005.8.26.0100, 29ª Câmara de Direito Privado, j. 07.03.2012).

739 “Art. 416. Para exigir a pena convencional, não é necessário que o credor alegue prejuízo.

Parágrafo único. Ainda que o prejuízo exceda ao previsto na cláusula penal, não pode o credor exigir indenização suplementar se assim não foi convencionado. Se o tiver sido, a pena vale como mínimo da indenização, competindo ao credor provar o prejuízo excedente".

740 "Art. 408. Incorre de pleno direito o devedor na cláusula penal, desde que, culposamente, deixe de cumprir a obrigação ou se constitua em mora".

${ }^{741}$ TEPEDINO, Gustavo. BARBOZA, Heloisa Helena. MORAES, Maria Celina Bodin de. Código Civil Interpretado Conforme a Constituição da República. Vol. I, 2. ed. rev. e atual., Rio de Janeiro: Renovar, 2007. p. 750.
} 
Conforme expusemos no primeiro capítulo, a culpa não é mais considerada o fundamento (único) do inadimplemento e da responsabilidade contratual, mas sim o nexo de imputação, que pode ser subjetivo ou objetivo, a depender da relação jurídica em concreto. Assim, melhor seria dizer que a cláusula penal é eficaz desde que caracterizada uma situação de inadimplemento imputável ao devedor.

Analisadas suscintamente as principais características da cláusula penal, não observamos óbices à exigibilidade das cláusulas penais em caso de inadimplemento antecipado $^{742}$. Como analisado no segundo capítulo, o inadimplemento antecipado é uma situação ordinária de inadimplemento da prestação devida que, conforme o caso concreto, enquadrar-se-ia como mora ou como inadimplemento absoluto. Daí concluir-se que a quebra antecipada permite a atribuição de todos os efeitos das categorias clássicas do inadimplemento (inadimplemento absoluto e mora), que podem ser produzidos imediatamente, em virtude da perda do benefício do termo pelo devedor.

O inadimplemento antecipado autoriza, assim, o credor a pedir a aplicação de eventual cláusula penal compensatória ou moratória prevista no contrato ou instrumento apartado celebrado entre as partes, conforme se trate de inadimplemento absoluto ou mora, independentemente do decurso do termo.

De acordo com a doutrina, o devedor incorre de pleno direito na cláusula penal quando a prestação for a prazo e houver inadimplemento no termo avençado e, não havendo sido estipulado prazo, o credor deverá constituir o devedor em mora por meio de interpelação judicial ou extrajudicial (artigo 397 do Código Civil), somente a partir de quando poderá ser cobrada a multa ${ }^{743}$. Assim, também no inadimplemento antecipado, em que o credor pretenderá cobrar a cláusula penal antes do transcurso do termo, ele deverá interpelar judicial ou extrajudicialmente o devedor para a cláusula penal tornar-se exigível.

\footnotetext{
742 TERRA, Aline de Miranda Valverde. Inadimplemento anterior ao termo. Rio de Janeiro: Renovar, 2009. p. 245 , nota 449 .

${ }^{743}$ PEREIRA, Caio Mário da Silva. Instituições de Direito Civil. vol. II. 20. ed. Rio de Janeiro: Forense, 2005. p. 104.
} 
É importante discutir a possibilidade de alteração do valor da cláusula penal no caso de inadimplemento antecipado. Em linhas gerais, o artigo 413 do Código Civil ${ }^{744}$ autoriza que o juiz reduza equitativamente o valor da cláusula penal se ele for manifestamente elevado e desproporcional ao descumprimento da obrigação, ou se a prestação foi cumprida parcialmente. Não obstante o legislador ter utilizado no mencionado artigo o termo "obrigação principal", relacionando-o, assim, com a cláusula penal compensatória, a doutrina também tem o aplicado para a redução de cláusula penal moratória $^{745}$.

Prevalece que o artigo 413 do Código Civil é matéria de ordem pública, o que autoriza a redução do valor da cláusula penal de ofício pelo magistrado ${ }^{746}$ e impede que as partes renunciem à possibilidade de redução do seu quantum se ocorrer qualquer das hipóteses previstas no artigo ${ }^{747}$. Face aos novos princípios norteadores da teoria contratual, como a boa-fé objetiva e a função social, não se pode admitir uma mera faculdade do juiz de aplicar ou não a norma em caso de excessiva desproporção da pena convencional, bem que as partes pudessem afastar a sua redutibilidade ${ }^{748}$.

Assim, também em uma situação de inadimplemento antecipado, o juiz deverá avaliar se não é o caso de reduzir equitativamente o quantum da cláusula penal diante de um cumprimento parcial das obrigações ou de uma cláusula penal manifestamente desproporcional, levando em consideração o momento do iter obrigacional em que restou

\footnotetext{
744 “Art. 413. A penalidade deve ser reduzida equitativamente pelo juiz se a obrigação principal tiver sido cumprida em parte, ou se o montante da penalidade for manifestamente excessivo, tendo-se em vista a natureza e a finalidade do negócio".

${ }^{745}$ LÔBO, Paulo. Direito civil: obrigações. 3. ed. São Paulo: Saraiva, 2013. p. 273. TEPEDINO, Gustavo. BARBOZA, Heloisa Helena. MORAES, Maria Celina Bodin de. Código Civil Interpretado Conforme a Constituição da República. Vol. I, 2. ed. rev. e atual., Rio de Janeiro: Renovar, 2007. p. 760.

${ }^{746}$ Neste sentido, confira-se o enunciado no 356 da IV Jornada de Direito Civil: "Nas hipóteses previstas no art. 413 do CC, o juiz deverá reduzir a cláusula penal de ofício". Carlos Roberto Gonçalves também entende que "a disposição é de ordem pública, podendo a redução ser determinada de oficio pelo magistrado" e "o art. 413 do novo Código Civil não dispõe que a penalidade 'poderá', mas sim que 'deve' ser reduzida pelo magistrado, nas hipóteses mencionadas” (GONÇALVES, Carlos Roberto. Direito civil brasileiro, vol. 2: teoria geral das obrigações. 8. ed. São Paulo: Saraiva, 2011. p. 414-415).

${ }^{747}$ Enunciado $\mathrm{n}^{\mathrm{o}} 355$ da IV Jornada de Direito Civil: "Não podem as partes renunciar à possibilidade de redução da cláusula penal se ocorrer qualquer das hipóteses previstas no art. 413 do CC, por se tratar de preceito de ordem pública".

${ }_{748}$ De acordo com o Superior Tribunal de Justiça, “a redução da cláusula penal preserva a função social do contrato na medida em que afasta o desequilíbrio contratual e seu uso como instrumento de enriquecimento sem causa" (STJ, REsp 1.212.159-SP, Rel. Min. Paulo de Tarso Sanseverino, j. 19.06.2012).
} 
caracterizado o inadimplemento, quais obrigações foram cumpridas pelo devedor, a gravidade da infração, o grau de culpa do devedor no descumprimento, as vantagens que para esse resultem do inadimplemento, o interesse do credor na prestação, a situação econômica das partes, a boa-fé dos contratantes, as características do contrato, entre outros fatores.

\subsection{Prescrição}

Questão tormentosa que permeia as discussões sobre o inadimplemento antecipado é a determinação do prazo prescricional. A ação corrosiva do tempo está presente nas relações jurídicas, e tem como consectário o instituto da prescrição ${ }^{749}$. Ao titular do direito subjetivo não é dado valer-se da sua pretensão ad infinitum, prejudicando a estabilidade das relações jurídicas. A prescrição surge, assim, como meio idôneo a preservar a segurança jurídica das relações.

A despeito das várias teorias debatidas pelos doutrinadores sobre a natureza jurídica da prescrição, atualmente prevalece a de que a "prescrição é um fenômeno que torna ineficaz a pretensão, ou seja, a possibilidade de o credor exigir do devedor o cumprimento de uma prestação de dar, fazer e não fazer" ${ }^{\text {"750 }}$. Em outras palavras, a prescrição deve ser compreendida como a extinção da pretensão ${ }^{751}$ surgida da violação a um direito subjetivo, decorrente da inércia do titular daquele direito. Esta parece ser a melhor interpretação a ser extraída do artigo 189 do Código Civil ${ }^{752}$.

\footnotetext{
${ }^{749}$ Sobre o tema da prescrição, recomenda-se a leitura de FILHO, Agnelo Amorim. Critério Científico para Distinguir a Prescrição da Decadência e para Identificar ações Imprescritíveis. Revista dos Tribunais, n. 744, 1997, p. 725-750.

${ }^{750}$ SIMÃO, José Fernando. Prescrição e decadência: início dos prazos. São Paulo: Atlas. 2013. p. 193.

${ }^{751}$ Com relação ao significado da palavra pretensão, confira-se: “[...] o conceito de pretensão, consoante o artigo 189 do Código Civil, deve ser definido como um poder de exigir o cumprimento da prestação pelas vias judiciais, ou, nas palavras de PONTES DE MIRANDA, 'pretensão é a posição subjetiva de poder exigir de outrem alguma prestação positiva ou negativa'. Esse poder de exigir, na dicção do texto normativo, pressupõe a violação do direito, do que resulta que a pretensão reclama, como antecedente lógico, que o sujeito passivo deixe de fazer o eu devia ou que faça o que não devia”. MARINANGELO, Rafael. Aspectos Relevantes da Prescrição e Decadência e o Novo Código Civil. In: NANNI, Giovanni Ettore (Coord.). Temas relevantes do direito civil contemporâneo: reflexões sobre os cinco anos do Código Civil. São Paulo: Atlas. 2008. p. 268-269.

752 “Art. 189. Violado o direito, nasce para o titular a pretensão, a qual se extingue, pela prescrição, nos prazos a que aludem os arts. 205 e 206."
} 


\section{Nas preciosas lições de Caio Mário da Silva Pereira:}

Para conceituar a prescrição, o Código partiu da idéia de pretensão. Foi a dogmática alemã que lhe deu origem. O titular de um direito subjetivo recebe da ordem jurídica o poder de exercê-lo, e normalmente o exerce, sem obstáculo ou oposição de quem quer. Se, entretanto, num dado momento, ocorre a sua violação por outrem, nasce para o titular uma pretensão exigível judicialmente Anspruch. O sujeito não conserva indefinidamente a faculdade de intentar um procedimento judicial defensivo de seu direito. A lei, ao mesmo tempo em que o reconhece, estabelece que a pretensão deve ser exigida em determinado prazo, sob pena de perecer. Pela prescrição, extingue-se a pretensão, nos prazos que a lei a estabelece (art. 189 do Código Civil de 2002). ${ }^{753}$

Assim, verificada a violação a um direito subjetivo, surgirá ao titular daquele direito a pretensão de exigir juridicamente a sua observância, restrito o exercício da pretensão, porém, a um prazo estipulado legalmente ${ }^{754}$. Ou seja, caso o credor permaneça inerte durante determinado lapso temporal, a lei determina o perecimento da pretensão de exigibilidade $^{755}$.

Com efeito, o inadimplemento antecipado do contrato implica em uma patente violação ao direito subjetivo do credor de receber a prestação no tempo, modo e lugar pactuados. Desta forma, diante do inadimplemento antecipado, o credor poderá, imediatamente (sem aguardar o decurso do termo), se valer da pretensão de exigibilidade,

\footnotetext{
${ }^{753}$ PEREIRA, Caio Mário da Silva. Instituições de direito civil. v. I. 21. ed. Rio de Janeiro: Forense. 2005. p. 682-683.

${ }^{754}$ Neste sentido: “[...] sendo assim, a redação do art. 189 explicita que, para a ocorrência da prescrição, deverá existir um direito e que, em sendo violado, surgirá uma pretensão para o seu titular, a qual, não sendo exercida dentro de um prazo determinado, desencadeará o fenômeno da prescrição." TEPEDINO, Gustavo. BARBOZA, Heloisa Helena. MORAES, Maria Celina Bodin de. Código Civil interpretado conforme a Constituição da República. v. I, 2. ed. rev. e atual. Rio de Janeiro: Renovar. 2007. p. 350.

${ }^{755}$ Confira-se: “[...] a prescrição ocorrerá, pois sempre que atendidos os seguintes pressupostos necessários: (a) exista o direito material da parte a uma prestação, negativa ou positiva, a ser cumprida; (b) ocorra a violação desse direito, configurando inadimplemento; (c) surja a pretensão, nascendo o poder de exigir a prestação pelas vias judiciais; e (d) o titular mantenha-se inerte, deixando de exercitar a pretensão durante o prazo extintivo fixado em lei." MARINANGELO, Rafael. Aspectos Relevantes da Prescrição e Decadência e o Novo Código Civil. In: NANNI, Giovanni Ettore (Coord.). Temas relevantes do direito civil contemporâneo: reflexões sobre os cinco anos do Código Civil. São Paulo: Atlas. 2008. p. 270. No mesmo sentido, "[...] para apurar a prescrição requer-se o consenso de dois elementos essenciais: o tempo e a inércia do titular. Não basta o decurso do lapsus temporis. Pode ele ser mais ou menos prolongado, sem que provoque a extinção da exigibilidade do direito. Ocorre, muitas vezes, que a não utilização deste é mesmo a forma de o exercer. Para que se consume a prescrição é mister que o decurso do prazo esteja aliado à inatividade do sujeito, em face da violação de um direito subjetivo. Esta, conjugada com a inércia do titular, implica a cessação da relação jurídica e extinção da pretensão". PEREIRA, Caio Mário da Silva. Instituições de direito civil. v. I. 21. ed. Rio de Janeiro: Forense. 2005. p. 683.
} 
buscando a resolução ou o cumprimento do contrato, bem como perdas e danos, sendo que o exercício dessa pretensão ficará sujeito à prescrição.

É importante destacar que o termo não é impeditivo para o surgimento da pretensão do credor em uma situação de inadimplemento antecipado e que o artigo 199, II, do Código Civil, que estabelece que não corre a prescrição "não estando vencido o prazo" não é óbice para a fluência do prazo prescricional.

Como expusemos no segundo capítulo, o termo ajustado em benefício do devedor ou de ambas as partes importa em inexigibilidade temporária da prestação, razão pela qual não começa a fluir o respectivo prazo de prescrição ${ }^{756}$. No entanto, em uma análise funcional do termo, concluímos que, se restar demonstrado que o termo não serve mais para permitir que o devedor cumpra a sua prestação, por fato que lhe seja imputável, impõe-se a perda do benefício do termo, e a prestação se torna, desde logo, exigível. Assim, surge a pretensão do credor e começa a fluir o prazo de prescrição.

Cumpre indagar, neste ponto, qual o prazo de prescrição a ser observado nos casos de inadimplemento antecipado. Parece-nos que o prazo de prescrição aplicável para o credor pleitear a resolução ou o cumprimento do contrato, bem como o ressarcimento pelas perdas e danos, em caso de inadimplemento antecipado, é o mesmo previsto pelo ordenamento jurídico para as hipóteses de mora ou de inadimplemento absoluto ${ }^{757}$, qual seja, o prazo estipulado no artigo $206, \S 3^{\circ}$, V, do Código Civil, que estabelece o prazo de três anos para a pretensão de "reparação civil".

\footnotetext{
${ }^{756}$ Confira-se: “[...] quando ainda não foi atingido o prazo estipulado para o adimplemento de uma obrigação, não poderá, igualmente, o titular do direito exigir o seu cumprimento, razão pela qual também não poderá, consequentemente iniciar a contagem do respectivo prazo prescricional. É o que dispõe o art. 199, II." TEPEDINO, Gustavo; BARBOZA, Heloisa Helena; MORAES, Maria Celina Bodin de. Código Civil interpretado conforme a Constituição da República. v. I. 2. ed. rev. e atual. Rio de Janeiro: Renovar. 2007. p. 379.

757 A esse respeito, Ruy Rosado Aguiar Júnior assevera que "se o direito resolução não é passível de prescrição, por inconciliável com sua natureza jurídica, nem de preclusão, por ausência de previsão legal, é preciso observar que o direito de crédito pode ter sua pretensão encoberta pela prescrição (prescrição de ação pessoal). Nesse caso, ensina PONTES DE MIRANDA, na sua precisão inexcedível: 'se o credor não mais podia cobrar, não mais pode pedir a resolução ou a resilição por inadimplemento porque o réu não em mais a obrigação de prestar, embora deva. Não há prescrição; há encobrimento do elemento, inadimplemento, necessário ao suporte fático da resolução ou da resilição. Portanto, o direito de resolução se extingue por efeito da prescrição da pretensão creditícia"”. AGUIAR JR., RUY ROSADO. Extinção dos contratos por incumprimento do devedor (resolução). Rio de Janeiro: Aide, 1991. p. 34.
} 
Filiamo-nos à orientação doutrinária segundo a qual o legislador, com a expressão "reparação civil", abrangeu em um único dispositivo as pretensões de reparação em responsabilidade contratual e aquiliana, sendo "importante notar que o dispositivo tem incidência tanto na responsabilidade civil contratual como extracontratual, haja vista a dicção ampla do preceito" ${ }^{\text {758 }}$. Nesta esteira, o Superior Tribunal de Justiça já se manifestou no sentido de que, "nas ações de reparação de dano por ilícito contratual, o prazo prescricional é de 3 (três) anos, nos termos do art. 206, § $3^{\circ}, \mathrm{V}$, do Código Civil de $2002^{, 759}$.

Ressalte-se que a aplicação do prazo trienal aos casos de inadimplemento contratual não é pacífica, havendo inclusive julgados dissonantes do próprio Superior Tribunal de Justiça ${ }^{760}$, que já decidiu pela aplicação do prazo decenal previsto no artigo 205 do Código Civil. Reiteramos, todavia, nosso entendimento pela aplicação do prazo prescricional de três anos, em razão do inadimplemento contratual ensejar reparação civil, nos termos do artigo 389 do Código Civil ${ }^{761}$.

Há, ainda, outra questão a ser abordada no que tange à prescrição no inadimplemento antecipado: a determinação do dies a quo do prazo prescricional. Precisar o momento do início da contagem do prazo prescricional em matéria de inadimplemento antecipado é tarefa árdua, sobre a qual a doutrina não tem se debruçado. Teceremos breves comentários sobre o tema, para apresentar o problema, o qual merecerá ser aprofundado em outra sede.

\footnotetext{
758 TEPEDINO, Gustavo; BARBOZA, Heloisa Helena; MORAES, Maria Celina Bodin de. Código Civil interpretado conforme a Constituição da República. v. I. 2. ed. rev. e atual. Rio de Janeiro: Renovar. 2007. p. 407. Neste sentido, o enunciado 419 da V Jornada de Direito Civil: "Art. 206, § 3 $3^{\circ}$, V: O prazo prescricional de três anos para a pretensão de reparação civil aplica-se tanto à responsabilidade contratual quanto à responsabilidade extracontratual."

${ }^{759}$ STJ, AgRg no Ag n ${ }^{\circ}$ 1085156-RJ, Rel. Min. Arnaldo Esteves Lima, j. 03.03.2009.

${ }_{760}$ Para ilustrar, confira-se: STJ, AgRg no REsp 1411828, Rel. Min. Nancy Andrighi, j. 07/08/2014; STJ, Resp 633.174-RJ, Rel. Min. Nancy Andrighi, j. 02.12.2004.

761 "Art. 389. Não cumprida a obrigação, responde o devedor por perdas e danos, mais juros e atualização monetária segundo índices oficiais regularmente estabelecidos, e honorários advocatícios."
} 
Sedimentou-se o entendimento de que o termo inicial da contagem dos prazos de prescrição seria o surgimento da pretensão, por trazer consigo a exigibilidade do direito subjetivo $^{762}$. Chegou-se, inclusive, a afirmar no Enunciado 14 da I Jornada de Direito Civil que "o início do prazo prescricional ocorre com o surgimento da pretensão, que decorre da exigibilidade do direito subjetivo" ${ }^{, 763}$. Exemplificando: em se tratando do direito subjetivo de crédito, o prazo prescricional se iniciaria com o não pagamento da dívida na data do seu vencimento.

Em matéria de responsabilidade contratual, o prazo prescricional para o credor pleitear a resolução ou o cumprimento do contrato, bem como o ressarcimento pelas perdas e danos, se iniciaria na data do inadimplemento, quando surge a pretensão do credor, pouco importando que ele conheça ou não o fato de o devedor ter descumprido o contrato $^{764}$. A respeito da questão, confiram-se as lições de José Fernando Simão:

\begin{abstract}
Se o credor conhece ou não o fato de o devedor ter descumprido a avença firmada, isto não reflete no início do prazo prescricional. Em realidade, na hipótese de inadimplemento da obrigação contratual, a lei presume que o credor terá a diligência de cuidar de seu maior interesse: o adimplemento contratual. Nas lições de Clóvis do Couto e Silva, o adimplemento é a finalidade da obrigação e, portanto, o adimplemento atrai, polariza. A conclusão a que se chega é a de que para o ordenamento não é relevante o fato de o credor desconhecer o inadimplemento contratual do devedor. Se desconhece, deveria conhecer por uma questão de diligência com a execução do contrato.

$\mathrm{Na}$ obrigação contratual, o valor segurança se revela evidente. Os prazos se iniciam com a violação, tenha o credor ciência ou não do inadimplemento. Alegar que não sabia que o descumprimento ocorrera, significa, em última
\end{abstract}

\footnotetext{
${ }^{762}$ FARIAS, Cristiano Chaves de; ROSENVALD, Nelson. Curso de direito civil 1. 11 $1^{\mathrm{a}}$. Ed. Salvador: Editora JusPodivm. 2013. p. 748.

${ }^{763}$ Existe também a tese da actio nata, adotada pela jurisprudência para os casos de responsabilidade extracontratual, segundo a qual o início da fluência do prazo prescricional deve ocorrer não da violação, em si, a um direito subjetivo, mas sim do conhecimento da violação ou lesão ao direito subjetivo pelo seu respectivo titular. Neste sentido, a súmula $\mathrm{n}^{\circ} 278$ do Superior Tribunal de Justiça: “[...] o termo inicial do prazo prescricional, na ação de indenização, é a data em que o segurado teve ciência inequívoca da incapacidade laboral." Confira-se o seguinte precedente: "[...] segundo a orientação jurisprudencial do Superior Tribunal de Justiça, o termo inicial do prazo prescricional das ações indenizatórias, em observância ao princípio da actio nata, é a data em que a lesão e os seus efeitos são constatados." (STJ, AgRg no Resp 1.248.981, Rel. Min. Mauro Campbell, j. 06.09.2012)

${ }^{764}$ Neste sentido, o seguinte precedente do Superior Tribunal de Justiça: "Na responsabilidade contratual, em regra, o termo inicial da contagem dos prazos de prescrição encontra-se na lesão ao direito, da qual decorre o nascimento da pretensão, que traz em seu bojo a possibilidade de exigência do direito subjetivo violado, nos termos do disposto no art. 189 do Código Civil, consagrando a tese da actio nata no ordenamento jurídico pátrio.” (STJ, REsp 1354348, Rel. Ministro Luis Felipe Salomão, j. 26.08.2014)
} 
análise, que o credor não se preocupou com a execução do contrato, ou seja, que ele foi descuidado. 765

Esse posicionamento, todavia, não é de simples transposição para o inadimplemento antecipado, dadas as suas peculiaridades, em especial a circunstância de se considerar que o devedor está inadimplente antes mesmo do decurso do termo contratual, que geralmente é o dies a quo para o início da contagem do prazo prescricional $^{766}$. Na tentativa de estabelecer o momento de início da contagem do prazo prescricional em matéria de inadimplemento antecipado, analisaremos algumas situações.

Com relação ao inadimplemento antecipado oriundo de manifestação expressa do devedor de não adimplir, estipular o início do prazo de prescrição não suscita grandes dúvidas. A manifestação do devedor dá-se em momento certo e preciso, e é neste que se configurará a violação do contrato e surgirá a pretensão do credor, iniciando-se a partir de então o prazo prescricional. Como exemplo, pode-se mencionar o caso da costureira contratada para confeccionar um vestido de noiva, que envia um e-mail para a sua cliente informando que não conseguirá prepará-lo para a data do casamento em virtude de problemas pessoais. Nesse caso, a violação do contrato e o início do prazo de prescrição ocorrem no dia do envio do e-mail pela costureira.

Quando o comportamento do devedor resultar em perda do objeto da prestação (hipótese de impossibilidade superveniente do cumprimento da prestação), o prazo terá fluência a partir do perecimento do objeto. Imagine-se a situação em que uma empresa que realiza cruzeiros internacionais encomenda um navio para ser construído e entregue no prazo de um ano. Se no décimo mês o galpão no qual estava sendo construído o navio vier a se incendiar por culpa do contratado, a destruição do navio corresponderá à perda do

\footnotetext{
${ }^{765}$ SIMÃO, José Fernando. Prescrição e decadência: início dos prazos. São Paulo: Atlas. 2013. p. 212.

${ }^{766}$ Vale conferir a explicação de José Fernando Simão: “[...] sendo a obrigação positiva (dar ou fazer), líquida (certa quanto à existência e determinada quanto ao valor) e com data de vencimento, ocorrendo a mora ou inadimplemento absoluto, inicia-se a pretensão e, com ela, a prescrição. É a data do vencimento o marco inicial da pretensão e da prescrição. Em exemplo simples, se o aluguel mensal de $\mathrm{R} \$ 1.000,00$ deve ser pago no dia 10 de cada mês, caso o inquilino não o pague, a mora se inicia no dia seguinte. Houve violação com o simples fato de não haver pagamento." SIMÃO, José Fernando. Prescrição e decadência: início dos prazos. São Paulo: Atlas. 2013. p. 211.
} 
objeto da prestação e consequentemente violação ao direito creditório. É a partir desse instante que deverá correr o prazo de prescrição.

A dificuldade em se estabelecer o dies a quo do prazo prescricional está nos casos de inadimplemento antecipado derivado do comportamento do devedor, que indique, com probabilidade próxima à certeza, que ele não adimplirá no tempo, modo e lugar avençados. Pense-se em uma compra e venda de unidade habitacional, a ser concluída em dois anos. Sabemos que uma inércia prolongada das obras poderá ensejar o inadimplemento antecipado. Como determinar, porém, o momento exato em que se configurou o inadimplemento antecipado? Esse exemplo demonstra que a fixação do termo inicial do prazo prescricional é extremamente complicada nos casos em que o inadimplemento antecipado decorre de uma manifestação tácita de não adimplir.

Uma definição casuística do dies a quo do prazo prescricional nos casos de inadimplemento antecipado provocado pelo comportamento do devedor poderia ensejar insegurança jurídica e injustiça, descumprindo as principais finalidades do instituto da prescrição $^{767}$. Isso porque, em muitos casos, não seria possível precisar o momento exato do inadimplemento, a dificuldade na fixação do termo inicial abriria espaço para muitos questionamentos e poderia permitir que o devedor se valesse de sua própria inadimplência para obter vantagem indevida, alegando que o inadimplemento antecipado se caracterizou em momento anterior somente para fulminar a pretensão do credor, o que afronta a boa-fé objetiva.

Por esses motivos, entendemos que, para essas situações de manifestação tácita de não adimplir, a prescrição somente começa a fluir a partir do termo contratual. Ou seja, pouco importa se o inadimplemento se deu antes do advento do termo, o prazo prescricional continua a fluir a partir do vencimento programado no contrato nas hipóteses em que a quebra antecipada decorrer do comportamento do devedor, que indicar, com

\footnotetext{
${ }^{767}$ Vale conferir os ensinamentos de José Fernando Simão: “[...] a interpretação quanto ao início da contagem dos prazos não passa por excluir segurança jurídica aplicando-se o valor da justiça, nem ao se fazer o inverso. A tese que se defende é a de que, apesar da dificuldade de aplicação da justiça (Serge-Christophe Kolm), é possível conciliar justiça e segurança sem apresentar um valor como preferível ao outro (Mario Losano)." SIMÃO, José Fernando. Prescrição e decadência: início dos prazos. São Paulo: Atlas. 2013. p. 204.
} 
probabilidade próxima à certeza, que ele não adimplirá no tempo, modo e lugar avençados.

Vale mencionar que a doutrina ${ }^{768}$ e a jurisprudência ${ }^{769}$ norte-americanas se orientam no sentido de que o início do prazo prescricional ocorre no dia do vencimento da obrigação para esses casos de inadimplemento antecipado decorrentes do comportamento do devedor.

Ademais, o Superior Tribunal de Justiça já decidiu de maneira semelhante, aplicando o mesmo raciocínio aos casos de vencimento antecipado da dívida, tendo afirmado que, "mesmo diante do vencimento antecipado da dívida, subsiste inalterado o termo inicial do prazo de prescrição - no caso, o dia do vencimento da última parcela", anotando que "a ninguém é admitido valer-se da própria torpeza. Ora, entender em favor da antecipação do prazo em questão beneficiaria o próprio devedor que criou o óbice para o recebimento do crédito",770.

\footnotetext{
${ }^{768}$ Neste sentido: "an anticipatory breach does not accelerate when the statute of limitations begins to run, but rather gives the nonbreaching party an option to sue immediately (...). The nonbreaching party is entitled to wait until performance is due" (KANE, Robert F., REZ, Donald G. California Pretrial Practice \& Forms. Volume 1. James Publishing. p. 3-37). Em tradução livre: "o inadimplemento antecipado não acelera quando o prazo prescricional começa a correr, mas dá à parte adimplente uma opção de imediatamente processar (...). A parte adimplente tem o direito de esperar até que o cumprimento é exigível." Fortunato Azulay afirma que: "sobre o repúdio antecipado ao cumprimento do contrato, CORBIN refere um precedente [norte-americano] no qual se firmou a regra de que o prazo de prescrição começa a correr do dia do vencimento da obrigação, pouco importando que a resilição se verifique antes" (AZULAY, Fortunato. Do inadimplemento Antecipado do Contrato. Rio de Janeiro: Editora Brasília/Rio, 1977. p. 135).

${ }^{769}$ Para ilustrar, vale mencionar o precedente Franconia Associates v. United States, 240 F.3d 1358, 1363-64 (Fed. Cir. 2001), no qual se decidiu que: "an anticipatory repudiation occurs when an obligor communicates to an obligee that the obligor will commit a breach in the future. Restatement (Second) of Contracts $\$ 250$ (a) (1981). In such a situation, the normal rule is that the statute of limitations begins to run from the date of performance specified in the contract unless the obligee elects to sue earlier for anticipatory breach". Em tradução livre: "o inadimplemento antecipado ocorre quando um devedor comunica ao credor que o devedor cometerá um inadimplemento no futuro. Reprodução (Second) of Contracts § 250(a) (1981). Em tal situação, a regra geral é que o prazo prescricional começa a correr da data da execução especificada no contrato, salvo se o credor decidir processar antes do termo por inadimplemento antecipado."

${ }^{770}$ STJ, REsp 1247168/RS, Rel. Min. Mauro Campbell Marques, j. 17.05.2001. Vale acrescentar ainda que "o vencimento antecipado do contrato não antecipa o termo inicial da prescrição da ação de execução em favor dos inadimplentes, que deram causa à rescisão" (AgRg no REsp 80268/RS, Rel. Min. Aldir Passarinho Junior, j. 28.01.2006). "O vencimento antecipado não altera o termo inicial do prazo quinquenal de prescrição para a cobrança de dívida fundada em contrato bancário." (STJ, AgRg no AREsp 261422 / RS, Rel. Ministra Maria Isabel Gallotti, j. 15.10.2013). "O vencimento antecipado das obrigações contraídas não altera o termo inicial para a contagem do prazo prescricional da ação cambial, que se conta do vencimento do título, tal como inscrito na cártula.” STJ, AgRg no Ag 138175 / PR, Rel. Ministro João Otávio de Noronha, j. 25.06.2013). No mesmo sentido: TJSP, Apelação n. ${ }^{\circ}$ 0184482-65.2009.8.26.0100, Rel. João Camilo de
} 
Acrescente-se que, muito embora o prazo de prescrição somente comece a fluir após o advento do termo nos casos de manifestação tácita de não adimplir, caso comprovado que o credor tinha efetivo conhecimento da situação de inadimplemento antecipado e nada fez para impedir o agravamento da situação do devedor, será aplicada a teoria do duty to mitigate de loss (dever de mitigar os prejuízos), o que ensejará uma redução do quantum indenizatório devido ao credor.

Em síntese, diante de uma situação de inadimplemento antecipado, o credor poderá, imediatamente, se valer da pretensão de exigibilidade, ficando sujeito ao prazo prescricional de três anos, com os seguintes termos iniciais: (i) na manifestação expressa de não adimplir, o prazo prescricional começa a fluir a partir da emissão e envio da declaração; (ii) na perda do objeto da prestação, o prazo terá fluência a partir do perecimento do objeto; e (iii) na manifestação tácita de não adimplir, a prescrição somente começa a fluir a partir do termo contratual.

\subsection{O inadimplemento antecipado na jurisprudência brasileira}

Além da crescente aceitação do instituto perante a doutrina brasileira, o inadimplemento antecipado do contrato também vem sendo reconhecido e aplicado pelos Tribunais do país. Apesar de ainda serem relativamente poucos os precedentes que expressamente a mencionam, a quebra antecipada já foi proclamada em diferentes Tribunais de Justiça dos Estados e, inclusive, no Superior Tribunal de Justiça. Analisar-seão alguns precedentes interesses que aplicaram o instituto na jurisprudência brasileira.

\subsubsection{Atraso na entrega de unidade de apartamento}

Almeida Prado Costa, j. 24.11.2014; TJSP, Apelação n. ${ }^{\circ}$ 0000799-29.2014.8.26.0042, Rel. Des. Gilberto dos Santos, j. 13/11/2014; TJSP, Apelação no 0035348-39.2011.8.26.0602, Rel. Des. Sérgio Shimura, j. $04 / 11 / 2014$ 
Um dos casos mais recorrentes de aplicação de inadimplemento antecipado na jurisprudência brasileira é o de atraso na entrega de unidades de apartamento ${ }^{771}$. Para ilustrar, será brevemente analisado o acórdão prolatado pelo Superior Tribunal de Justiça no julgamento do Recurso Especial $\mathrm{n}^{\circ}$ 309.626, de relatoria do Ministro Ruy Rosado Aguiar $^{772}$.

No acórdão em comento, o autor ajuizou demanda contra uma construtora para resolver contrato de promessa de compra e venda de uma unidade de apartamento, que seria construído pela ré, mas cujas obras ainda não tinham sido iniciadas apesar do tempo decorrido.

As partes contrataram a compra e venda de um apartamento a ser construído pela empresa ré, com entrega prevista para novembro de 1999. Como em julho de 1998 as obras ainda não estavam iniciadas, a que se aliaram a outras circunstâncias que confirmavam a ideia de que o prédio não seria construído (por exemplo, a notória situação de insolvência da construtora), o promissário comprador promoveu ação de resolução do contrato, com pedido de devolução do que despendeu durante dois anos.

Diante dos fatos delineados pelas instâncias inferiores, o Ministro Ruy Rosado Aguiar entendeu que o caso configurava uma hipótese de inadimplemento antecipado, sob o fundamento de que a construtora tomou atitude claramente contrária à avença ao não iniciar as obras após dois anos da celebração do contrato (faltando menos de um ano para o termo), demonstrando firmemente que não cumpriria o contrato. Assim, o Ministro concluiu que "evidenciado que a construtora não cumprirá o contrato, o promissário comprador pode pedir a extinção da avença e a devolução das importâncias que pagou".

\footnotetext{
771 TJSP, Apelação no 4001612-76.2012.8.26.0100, Rel. Des. Edson Luiz de Queiroz, j. 17.09.2014; TJSP, Apelação $\mathrm{n}^{\circ}$ 994.03.110649-1, Rel. Desembargador Piva Rodrigues, j. 09.03.2010; TJRJ, Apelação $\mathrm{n}^{\circ}$ 0117017-71.2008.8.19.0001, Rel. Des. Célia Maria Vidal Meliga Pessoa, j. 07.01.2011; TJRJ, Agravo ${ }^{\circ}$ 0004042-10.2011.8.19.0000, Rel. Des. Odete Knaack de Souza, j. 27.04.2011; TJDF, Apelação no 000151885.2002.807.00001, Rel. Hermenegildo Gonçalves, j. 13.05.2002.

${ }^{772}$ STJ, Recurso Especial no 309.626, Rel. Ministro Ruy Rosado Aguiar, j. 07.06.2001.
} 
O Ministro ressaltou em seu acórdão que é perfeitamente cabível o imediato ${ }^{773}$ pedido de resolução do contrato em um caso de quebra antecipada e que, com o atendimento do pedido, cumpre ao magistrado determinar a restituição das partes à situação anterior, o que significa, no exemplo, a necessidade de deferir o pedido de devolução das importâncias pagas pelo promissário comprador, enquanto confiou no contrato.

Frisou, ainda, que a cláusula de decaimento estipulada no contrato, com a perda em favor da construtora do que despendera o autor, não tem validade nos casos em que "o comprador sai do contrato por impossibilidade relativa de continuar cumprindo com as prestações mensais; com muito mais razão na hipótese sob exame, em que se está atribuindo à ré a culpa pelo inadimplemento".

Como se observa, o Ministro Ruy Rosado Aguiar reconheceu, de maneira explicita, a configuração da quebra antecipada do contrato em razão do comportamento concludente do devedor em sentido contrário ao cumprimento, admitindo a resolução do contrato e determinando as demais medidas pertinentes antes do advento do termo ${ }^{774}$.

\subsubsection{Prestação de serviços educacionais - curso de mestrado no exterior}

O Tribunal de Justiça de São Paulo ${ }^{775}$ julgou interessante caso em que uma aluna ajuizou uma ação contra uma instituição de ensino requerendo a resolução de contrato de prestação de serviços educacionais, cujo objeto consistia na realização de um curso de mestrado no exterior.

\footnotetext{
${ }^{773}$ Inclusive, consta do relatório que no acórdão recorrido foi consignado que "diante dos fatos antecipados, não pode a recorrente querer que o comprador só mova a demanda em julho de 2010, quando da prorrogação do prazo de carência para a entrega prevista no acordo, pois não é razoável que o apelado espere o esgotamento deste interregno para propor a ação, se há fundado e irrefutável receio de descumprimento da obrigação contratual, pela mora injustificada da outra contratante".

774 Para ilustrar, segue a ementa de um acórdão do TJSP no mesmo sentido: "COMPROMISSO DE COMPRA E VENDA DE IMÓVEL - Ação de resolução do contrato e devolução das quantias pagas Sentença de improcedência - Inconformismo - Acolhimento - Aplicação da teoria do inadimplemento antecipado - Examinando-se as condutas praticadas pela ré, é possível afirmar que, inevitavelmente, as obras não estariam prontas no tempo convencionado, fato apenas corroborado pela notícia de que até os dias atuais a construção do imóvel não foi concluída - Improcedência da ação reconvencional - Recurso provido." (TJSP, Apelação n ${ }^{\circ}$ 994.03.110649-1, Rel. Desembargador Piva Rodrigues, j. 09.03.2010).

775 TJSP, Apelação nº 0202518-53.2012.8.26.0100, Rel. Edgard Rosa, j. 20.03.2014.
} 
$\mathrm{Na}$ situação concreta, após celebrar o contrato de prestação de serviços educacionais e pagar a integralidade da sua contraprestação, a aluna viajou até a Itália pouco tempo antes do início das aulas do curso de mestrado, mas lá foi informada por representantes da instituição de ensino de que, em razão do reduzido número de alunos então inscritos, haveria a possibilidade de cancelamento do curso ou de seu deslocamento para outra cidade ou universidade. $O$ teor das comunicações enviadas pela instituição de ensino fez com que a aluna desistisse do curso de mestrado já pago.

Na oportunidade, a instituição de ensino se valeu de cláusula prevista no contrato celebrado entre as partes, segundo a qual "o Instituto Europeo di Design se reserva ao direito de cancelar os cursos de Mestrado, dentro de um mês da data prevista de início. Os alunos matriculados serão informados através de comunicado escrito e todas as taxas já pagas serão reembolsadas, sem nenhum custo adicional".

O Desembargador Edgard Rosa, relator do acórdão, reconheceu a existência de relação de consumo entre a instituição de ensino e a autora, por ser a última destinatária final dos serviços educacionais prestados, e declarou a nulidade da referida cláusula contratual, que se mostrou manifestamente abusiva, pois, ao permitir o cancelamento do curso por mera conveniência da instituição, admite que o fornecedor unilateralmente modifique o contrato de prestação de serviços educacionais.

Diante desta situação, o Tribunal de Justiça de São Paulo concluiu ter ocorrido o inadimplemento antecipado da obrigação por parte da instituição de ensino, tendo em vista que ela, valendo-se de previsão manifestamente abusiva, incutiu na consumidora concreto temor de que o curso escolhido não seria ministrado, o que culminou no seu inadimplemento antes do termo contratual. Segundo consta do acórdão, "restou claro que a desistência do curso pela autora se deu pela ameaça concreta de seu cancelamento, mostrando-se irrelevante a alegação da ré de que o curso somente se iniciaria meses depois de extinta a avença entre as partes". 
Assim, o Tribunal declarou a resolução do contrato e determinou que a instituição de ensino indenizasse a aluna pelos danos materiais (devolução da taxa de matrícula, mensalidades pagas, valores atinentes ao seguro viagem contratado, às passagens aéreas adquiridas, despesas com hotel) e danos morais decorrentes do inadimplemento verificado.

\subsubsection{Plantio de cana de açúcar}

O Tribunal de Justiça de São Paulo ${ }^{776}$ apreciou caso em que o autor propôs ação de rescisão contratual em face de uma destilaria, aduzindo, em síntese, que, em 17.07.2008, celebrou contrato de venda e compra de cana de açúcar com cláusula de exclusividade, pactuando que forneceria à ré a totalidade da cana produzida em suas propriedades rurais nas safras de 2008 até 2013, sendo que a destilaria deveria colhê-la e adquiri-la; a destilaria passou a inadimplir a sua obrigação de pagamento da safra a partir de maio de 2010 e não efetuou a colheita da safra 2010/2011; e que o autor corre o risco de ver sua lavoura de 2012 perecer e amargar enormes prejuízos financeiros, diante da inércia da destilaria.

No caso, o Tribunal concluiu que o inadimplemento da destilaria quanto à obrigação de pagar as safras da cana de açúcar colhidas, aliado à deliberação social da destilaria de interromper o exercício da sua atividade por seis anos e à inércia na resposta à notificação premonitória enviada pelo autor determinando conduta positiva quanto à colheita da safra pendente, autorizaram a configuração do inadimplemento antecipado, com a produção de efeitos imediatos. Segundo consta no acórdão, é “irrazoável exigir do credor aguardar o recebimento de eventual indenização contratada caso não fosse realizada a colheita, em função da exclusividade".

Assim, o Tribunal julgou parcialmente procedente a demanda, para resolver o contrato de venda e compra de cana de açúcar celebrado entre as partes e condenar a

\footnotetext{
${ }^{776}$ TJSP, Apelação no 0005278-49.2010.8.26.0319, Rel. Hamid Bdine, j. 01.10.2014.
} 
destilaria ao pagamento das parcelas pendentes de pagamento e da multa estipulada no contrato (a qual foi reduzida equitativamente em virtude do adimplemento parcial).

\subsubsection{Contrato de compra e venda de quotas e fundo de comércio}

O Tribunal de Justiça de São Paulo ${ }^{777}$ julgou caso em que as partes celebraram contrato de compra e venda de fundo de comércio e de alienação de quotas sociais pelo valor de $\mathrm{R} \$ 50.000,00$ (cinquenta mil reais), que seriam pagos em parcelas de $\mathrm{R} \$ 1.000,00$ (mil reais). Acordaram as partes, ainda, que os adquirentes assumiriam a responsabilidade por dívidas trabalhistas referentes a dois empregados, bem como por três empréstimos. Ocorre que os compradores, embora tenham realizado alteração do contrato social perante a Junta Comercial, deixaram de pagar não somente as parcelas do preço, como também não quitaram as dívidas assumidas junto a terceiros, tanto que o vendedor sofreu negativações em seu nome. Os vendedores exigiram, assim, o pagamento imediato de todas as parcelas estipuladas no contrato e indenização por danos materiais e morais.

Segundo entendeu o Tribunal, tendo em vista que à época do ajuizamento da demanda os compradores já haviam inadimplido sete parcelas do preço e no curso do processo não pagaram as subsequentes, os compradores não assumiram as dívidas dos empréstimos, não pagaram os aluguéis do imóvel em que se situava o estabelecimento e alienaram os bens do fundo do comércio, "já se pode cogitar de um inadimplemento antecipado por parte dos réus, sem que seja necessário antes aguardar o vencimento de cada uma das parcelas pactuadas".

O Tribunal reconheceu, portanto, o inadimplemento antecipado do contrato, admitindo o vencimento antecipado de todas as parcelas do preço e condenando os compradores ao pagamento do preço pactuado no contrato de compra e venda. O Tribunal determinou, ainda, que o autor teria o direito de se voltar em regresso contra os compradores (i) caso viesse a ser atingido por ações e execuções trabalhistas; e (ii) caso fosse condenado ao pagamento dos valores dos empréstimos feitos junto às instituições

\footnotetext{
${ }^{777}$ TJSP, Apelação nº 0013213-07.2012.8.26.0664, Rel. Francisco Loureiro, j. 05.12.2013.
} 
financeiras. Esse acórdão é um interessante exemplo de tutela específica em caso de inadimplemento antecipado.

\subsubsection{Contrato de compra e venda de mercadorias e licença gratuita de marca}

O Tribunal de Justiça de São Paulo ${ }^{778}$ julgou caso em que as partes firmaram contrato de venda e compra de mercadorias e de licença gratuita da marca "Andorinha Ferramentas Ltda.”. Pelo ajuste, a autora assumiu a obrigação de comprar mobiliário e o estoque da ré, que se comprometeu a entregá-lo livre e desembaraçado de quaisquer ônus, além de ter sido negociado o licenciamento da marca, que passaria a ser usada de forma exclusiva pela autora. Sucede que, após a formalização do contrato, a autora descobriu que, alguns meses antes, dois filhos de ambos os sócios da ré constituíram sociedade para a qual deram a denominação social de "Andorinha Comercial Ltda." e que tinha objeto social semelhante ao da ré. A autora requereu, portanto, a resolução do contrato e o retorno das partes ao status quo.

O Desembargador Carlos Alberto Garbi entendeu que a constituição de nova sociedade pelos filhos dos sócios da ré, poucos meses antes do negócio envolvendo a marca "Andorinha", sociedade que recebeu o mesmo nome que seria objeto de negociação poucos meses depois, e com objetos sociais muito semelhantes aos da ré, demonstra que houve má-fé preordenada, caracterizadora da concorrência desleal.

Segundo consta do acórdão, "emerge do quadro dos autos que os sócios da ré não pretendiam deixar o mercado", "buscavam apenas alienar o estabelecimento comercial e a marca, porquanto a empresa tinha pendências financeiras" e que "os sócios da ré continuariam a explorar idêntica mercancia por intermédio da sociedade constituída em nome de seus filhos".

No entender do Tribunal, houve concorrência desleal, que, por si só, já seria causa suficiente para o desfazimento do negócio, e restou caracterizado o inadimplemento

\footnotetext{
${ }^{778}$ TJSP, Apelação no 9136513-12.2006.8.26.0000, Rel. Des. Carlos Alberto Garbi, j. 04.10.2011.
} 
antecipado do contrato, sob a justificativa de que "a constituição da nova sociedade poucos meses antes da alienação do fundo de comércio e da marca para a autora demonstrou, como já se disse, preordenação dos atos dos sócios da ré ao descumprimento da obrigação, o que caracteriza o inadimplemento antecipado do ajuste".

O Tribunal concluiu, assim, que o contrato firmado entre as partes foi descumprido pela ré. Diante disso, julgou procedente o pedido da autora para declarar resolvido o contrato firmado entre as partes, determinando o retorno das partes ao estado anterior ao ajuste, devendo a autora devolver à ré as mercadorias recebidas e o valor daquelas que vendeu, e a ré, por sua vez, devolver à autora os valores recebidos pelo negócio.

\subsubsection{Síntese conclusiva}

Diante desse breve panorama jurisprudencial, é possível confirmar a amplitude que o inadimplemento antecipado vem ganhando perante os Tribunais do país. No entanto, até o presente momento, a maioria dos casos de aplicação do instituto pelos Tribunais se restringe ao comportamento concludente do devedor, voltado especificamente para casos de construção com prazo certo. Ainda assim, esse cenário comprova, invariavelmente, a aceitação do instituto pelo direito brasileiro. 


\section{CONCLUSÃO}

O direito das obrigações, assim como qualquer outro ramo do Direito, sofre os influxos e conforma a sociedade em cada período histórico, fazendo com que o jurista tenha que criar e reler os seus instrumentos e institutos para conferir conteúdo normativo a tal realidade e promover as modificações que se fizerem necessárias.

As transformações sociais e econômicas verificadas a partir da segunda metade do século XIX (acentuado desnivelamento social, crises econômicas, massificação das relações, etc) fizeram com que a doutrina começasse a defender uma "revisão axiológica" do direito das obrigações, de maneira que as relações privadas também devessem se preocupar com as noções de cunho valorativo, como a eticidade e a solidariedade.

$\mathrm{Na}$ esteira desse movimento, promulga-se no Brasil a Constituição Federal de 1988, preocupada com a criação de uma sociedade mais justa, livre e solidária, com vida digna para todos; e o Código Civil de 2002, com um "sistema aberto em que as cláusulas gerais permitissem ao juiz uma permanente criação e recriação do direito civil"779 e com novos princípios contratuais (boa-fé objetiva, equilíbrio econômico do contrato e função social do contrato), que realçam a exigência de que as relações privadas devem se preocupar com as ideias de eticidade e solidariedade.

Embora o "tecido normativo das obrigações [se tenha] mantido imune a qualquer projeto de reforma, não merecendo mais que alterações tímidas da parte do legislador" ${ }^{780}$, o jurista poderá e deverá realizar uma releitura do regramento, dos conceitos e institutos do direito das obrigações, valendo-se das normas constitucionais e das cláusulas gerais previstas no Código Civil de 2002, especialmente a boa-fé objetiva, para permitir que esse campo do direito civil esteja apto a solucionar os conflitos atualmente existentes na sociedade.

\footnotetext{
${ }^{779}$ SIMÃO, José Fernando. Prescrição e decadência: início dos prazos. São Paulo: Atlas, 2013. p. 276.

780 SCHREIBER, Anderson. A Boa-fé objetiva e o Adimplemento Substancial. In: HIRONAKA, Giselda Maria Fernandes Novaes; TARTUCE, Flávio (Coord.). Direito contratual. Temas Atuais. São Paulo: Método. 2007. p. 128.
} 
Sob essa perspectiva, buscou-se empreender estudo crítico a respeito do inadimplemento e, em particular, do inadimplemento antecipado do contrato, a partir do qual se extraíram algumas conclusões, paulatinamente já referidas ao longo deste estudo. A fim de melhor sistematizá-las, passa-se, então, a elencar aquelas que assumem maior relevância para o tema proposto.

1. Apesar de assistir razão a Araken de Assis ao asseverar que "a figura se ressente de previsão legislativa explícita, equiparando o inadimplemento antecipado ao absoluto, ou de autorização inequívoca ao credor para ignorar o termo",781, entendemos que é possível extrair a disciplina do instituto em exame da atual sistemática obrigacional prevista no Código Civil de 2002.

A precisa compreensão do tema se subordina, todavia, à releitura de alguns conceitos e institutos clássicos à luz da atual concepção dinâmica, finalística e funcionalizada de relação obrigacional, fortemente influenciada pelo princípio da boa-fé objetiva. Neste sentido, convém destacar os seguintes pontos:

a concepção tradicional de obrigação, consubstanciada na ideia de uma submissão do devedor ao credor, vem sendo paulatinamente abandonada em favor de um novo conceito de relação obrigacional, composto por direitos e deveres recíprocos das partes, que convergem para a consecução de um escopo comum;

a obrigação passa a ser vista como um processo (concepção dinâmica), no qual ambas as partes - e não apenas o devedor - devem cooperar para atingir uma finalidade, que é o adimplemento contratual e a satisfação dos interesses das partes contratantes;

(iii) o conteúdo da relação obrigacional deixa de ser resultado apenas da vontade das partes e passa a ser determinado também pela boa-fé objetiva, que impõe às partes deveres anexos de conduta dirigidos à satisfação dos interesses envolvidos na

\footnotetext{
${ }^{781}$ ASSIS, Araken de. Resolução do Contrato por Inadimplemento. $4^{\circ}$ ed. São Paulo: Revista dos Tribunais. 2004. p. 109.
} 
relação obrigacional;

a execução da prestação principal, por si só, passa a não ser considerada capaz de atender ao interesse objetivo e concreto do credor. Somente o comportamento do devedor dirigido concomitantemente à execução da prestação principal, bem como dos deveres de conduta anexos impostos pela boa-fé objetiva, permitirá a plena satisfação do interesse do credor e o atingimento do resultado útil programado. Nesse sentido, passa-se a entender a prestação como uma prestação satisfativa;

(v) o alargamento do objeto da obrigação impõe a superação da tradicional concepção de adimplemento, segundo a qual este se perfaz com o simples cumprimento da prestação principal. Atualmente, o adimplemento não se subordina apenas à execução da prestação principal, mas depende, também, da efetiva produção do resultado útil programado e da satisfação do interesse do credor;

(vi) examinado o adimplemento sob essa noção complexa e funcional, verifica-se uma profunda transformação de diversos aspectos do adimplemento, entre os quais o temporal (momento de verificação do adimplemento), o conceitual (condições para verificação do adimplemento) e consequencial (efeitos que decorrem do adimplemento);

(vii) o adimplemento assume uma perspectiva temporal, consistindo em um processo dinâmico dentro do qual o devedor deve executar uma série de atos e observar inúmeros deveres (principais, secundários e anexos) necessários ao adimplemento no tempo, lugar e forma acordados. O adimplemento não se restringe ao momento em que a prestação deve estar cumprida, mas se desdobra ao longo de todo o iter obrigacional;

(viii) diante da percepção de que o direito obrigacional assumiu aspecto dinâmico e de que o adimplemento não se restringe ao momento em que a prestação deve estar cumprida, mas se desdobra ao longo de toda a relação obrigacional, a doutrina moderna começou a sustentar que a infringência de deveres de conduta e de deveres laterais pode configurar um inadimplemento antecipado do contrato; 
(ix) a ampliação do conceito de adimplemento implica, na mesma medida, no alargamento da noção de inadimplemento. Nessa visão, o inadimplemento poderá ser ocasionado não só pela quebra dos deveres de prestação, mas também pela violação dos deveres anexos antes, durante e depois da celebração do negócio jurídico. A violação de quaisquer deveres conduz ao não cumprimento da prestação devida e, consequentemente, ao inadimplemento (em sentido amplo). Agora, se a violação a um dever obrigacional (principal, secundário ou anexo) acarreta a mora ou o inadimplemento absoluto (espécies de inadimplemento), isto é uma questão que apenas se responde à luz do caso concreto. O descumprimento de quaisquer deveres configurará inadimplemento absoluto, se a prestação devida se tornar impossível ou inútil para o credor; ou mora, desde que o seu cumprimento se afigure possível ao devedor e útil ao credor.

2. Em linhas gerais, o inadimplemento antecipado da obrigação pode ser conceituado como o inadimplemento que ocorre quando uma das partes da relação obrigacional, antes do termo contratual ou do momento em que deveria executar uma determinada prestação, declara que não quer ou não pretende cumprir a obrigação ou coloca-se em posição que torne impossível ou inútil o cumprimento da obrigação no prazo avençado entre as partes.

Extraem-se da definição acima os principais elementos do instituto do inadimplemento antecipado: (i) ele consiste em uma forma de inadimplemento; (ii) ocorre, necessariamente, antes do termo contratual; (iii) esta forma de inadimplemento pode manifestar-se seja por uma renúncia (expressa ou tácita) ao cumprimento da obrigação, ou pelo fato do obrigado colocar-se em posição que torna o adimplemento impossível; e (iv) ele deve ser provocado por ato ou fato imputável ao devedor.

3. A exata configuração do inadimplemento antecipado é imprescindível, sob pena de se adotar contra o devedor medida mais rigorosa do que aquela que seja a legítima consequência do seu comportamento. Portanto, deve-se examinar com rigor seus suportes fáticos objetivos, quais sejam:

(i) manifestação expressa do devedor de não querer 
adimplir, na qual o devedor declara explicitamente que não cumprirá a prestação, por não querer ou não poder fazê-lo, de modo a não satisfazer o interesse do credor. Destaque-se que não é qualquer declaração que poderá caracterizar inadimplemento antecipado; tal declaração deve ser séria, dotada de certeza e definitividade e livre de quaisquer vícios de consentimento;

(ii) manifestação tácita do devedor de não querer adimplir, que se verifica nas situações nas quais o devedor se comporta no sentido oposto ao do adimplemento, ou seja, nas situações em que é possível inferir da conduta do devedor que ele não pretende cumprir a sua obrigação. O pressuposto para a caracterização dessa hipótese de inadimplemento antecipado é a probabilidade próxima à certeza da intenção de não adimplir, exteriorizada por meio de conduta do devedor incompatível com o padrão de comportamento de quem pretende cumprir a prestação devida;

(iii) manifestação do devedor no sentido de não poder adimplir, que ocorre nas situações em que o comportamento do devedor, comissivo ou omissivo, impossibilite desde logo a prestação. Diferentemente das outras hipóteses, a impossibilidade de cumprir a prestação antes do termo contratual caracteriza-se não pelo elemento subjetivo (vontade de não adimplir), mas pelo elemento objetivo: o fato de o devedor, por ato próprio, criar situação que impossibilitará a entrega da prestação devida.

4. No inadimplemento antecipado, assim como acontece no inadimplemento que se configura após o advento do termo, basta um nexo de imputação, que pode ser subjetivo ou objetivo, não sendo necessária sempre e necessariamente a culpa do devedor. O tipo de nexo de imputação necessário para ensejar a responsabilidade contratual dependerá da relação obrigacional específica, da legislação e das cláusulas contratuais. 
5. O instituto objeto do presente estudo se aplica:

(i) às relações obrigacionais, isto é, àquelas relações caracterizadas pela patrimonialidade da prestação; excluem-se de sua incidência as relações existenciais;

(ii) às obrigações com termo fixado em benefício do devedor ou de ambas as partes;

(iii) tanto aos contratos bilaterais quanto aos unilaterais, haja vista que o instituto não se relaciona necessariamente à manutenção do sinalagma;

(iv) aos contratos relacionais, que exigem das partes um dever geral de colaboração ainda mais acentuado, sendo um campo especial de aplicação do instituto do inadimplemento antecipado.

6. Qualquer que seja o suporte fático do inadimplemento antecipado, a violação de qualquer dever obrigacional abalará a prestação devida e obstruirá o caminho em direção ao resultado útil programado, o que caracteriza situação de inadimplemento (em sentido lado).

Assim, é possível qualificar o inadimplemento antecipado como uma situação ordinária de inadimplemento, que pode culminar em inadimplemento absoluto ou mora, a depender da possibilidade de cumprimento da prestação (na acepção técnico-jurídica da palavra) e da permanência de utilidade da prestação para o credor após o advento do termo.

Se o devedor descumpre um dever obrigacional (principal, secundário ou lateral), acarretando o inadimplemento antecipado do contrato, configura-se (i) inadimplemento absoluto, se a prestação se tornar impossível de ser adimplida ou inútil para o credor; ou (ii) mora, nos casos em que a inobservância do dever de conduta ensejar apenas o retardamento da prestação, ou o cumprimento da prestação em desacordo com o tempo, modo e lugar pactuados, sem lhe retirar a utilidade para o credor.

7. O reconhecimento de que o inadimplemento antecipado se fundamenta no inadimplemento da prestação devida permite atribuir-lhe todos os efeitos das categorias 
clássicas do inadimplemento (inadimplemento absoluto e mora), inclusive a tutela específica e a exigibilidade da cláusula penal, que podem ser produzidas imediatamente, em virtude da perda do benefício do termo pelo devedor.

Independentemente do seu suporte fático, o primeiro efeito do inadimplemento antecipado reside na imposição, ao devedor, do dever de indenizar os danos causados, nos termos do artigo 389 do Código Civil. É importante lembrar que a configuração do inadimplemento antecipado impõe ao credor o dever de mitigação dos danos, a exemplo do duty to mitigate the loss da common law, pelo qual a parte que invoca o descumprimento contratual tem o dever de tomar, assim que possível, todas as medidas razoáveis para limitar o dano. A inobservância do dever de mitigar danos terá repercussão importante no cálculo do montante indenizatório a que o credor fará jus em caso de inadimplemento antecipado.

Os demais efeitos do inadimplemento antecipado dependem da possibilidade de o credor receber a prestação devida. Configurado o inadimplemento absoluto, conferem-se ao credor duas opções: ajuizar ação visando à resolução contratual, ou ao cumprimento do contrato, se preferir mantê-lo (artigo 475 do Código Civil). Por outro lado, configurada a mora do devedor, abre-se ao credor apenas esta última alternativa.

8. Como analisado, uma situação de inadimplemento antecipado permite ao credor se valer, imediatamente, da pretensão de exigibilidade, ficando sujeito ao prazo prescricional de três anos, com os seguintes termos iniciais: (i) na manifestação expressa de não adimplir, o prazo prescricional começa a fluir a partir da data da declaração; (ii) na perda do objeto da prestação, o prazo terá fluência a partir do perecimento do objeto; e (iii) na manifestação tácita de não adimplir, a prescrição somente começa a fluir a partir do termo contratual.

9. O inadimplemento antecipado não pode ser confundido com a figura do risco de descumprimento, que enseja consequências jurídicas diversas. $\mathrm{O}$ inadimplemento antecipado exige uma probabilidade próxima da certeza de que o credor não desejará ou conseguirá adimplir a prestação no termo contratual; o risco de descumprimento se aplica 
àquelas situações em que o devedor - por seu comportamento ou pela deterioração do seu patrimônio - torna duvidosa, com um alto de grau de probabilidade, a entrega da prestação devida no momento, modo e lugar pactuado entre as partes.

Em princípio, a resolução do contrato ficaria reservada àqueles casos em que o cumprimento da obrigação no vencimento futuro se afigurasse, com probabilidade próxima à certeza, impossível ou extremamente difícil. Nesta hipótese, o inadimplemento antecipado conferiria ao credor a possibilidade de resolver o contrato com fundamento no artigo 475 do Código Civil, podendo o interessado, ainda, optar pela execução específica da obrigação, nos termos dos artigos 461 e 461-A do Código de Processo Civil. Por sua vez, nas situações de risco de descumprimento, seriam aplicáveis as consequências jurídicas previstas no artigo 477 do Código Civil, as quais autorizam o contratante a recusar-se à prestação que lhe compete, até que a outra parte satisfaça a que lhe incumbe ou dê garantia bastante para fazê-la.

10. A noção da "obrigação como processo" passou a exigir a cooperação do credor, seja por meio de um comportamento ativo, ou passivo, para viabilizar o adimplemento contratual e a satisfação do interesse das partes. A ausência de colaboração do credor no programa obrigacional - seja com relação a deveres principais, secundários ou laterais - pode consistir na principal causa do inadimplemento antecipado do contrato.

Se o credor descumprir o seu dever de cooperar, provocando uma situação de inadimplemento antecipado, isso poderá acarretar (i) uma situação de mora accipiendi, se o adimplemento ainda for possível e útil, na qual o devedor permanecerá vinculado ao cumprimento da obrigação, mas incidirão os efeitos da mora do credor previstos no artigo 400 do Código Civil; ou (ii) uma situação de inadimplemento absoluto por fato imputável ao credor, se o adimplemento for impossível ou inútil, excluindo-se a responsabilidade do devedor nos moldes do artigo 393 do Código Civil, e liberando-o do vínculo obrigacional.

Para que o devedor não fique eternamente vinculado a uma relação obrigacional a cuja situação de inadimplemento antecipado ele não deu causa, ele poderá ajuizar uma demanda de cumprimento ou uma ação de resolução contra o credor, a 
depender do caso concreto, sendo sempre cabível o pedido de indenização por perdas e danos.

11. Vale mencionar que, embora o instituto do inadimplemento antecipado vise simplificar a resolução contratual, evitando-se que o credor tenha que esperar até o termo do contrato para requerer as medidas pertinentes, a sua aplicação deve ocorrer com cautela. O instituto em estudo deve encontrar limites nas figuras do abuso do direito, da proibição ao comportamento contraditório (venire contra factum proprium), do adimplemento substancial, do princípio da conservação dos negócios jurídicos e da função social dos contratos, a fim de se evitar que qualquer declaração ou comportamento do devedor seja apto a caracterizar o inadimplemento antecipado do contrato.

12. A análise de diversos casos concretos trazidos ao longo do texto procurou evidenciar o suporte fático objetivo do inadimplemento antecipado, os efeitos do seu reconhecimento e os seus limites, para contribuir para o seu estudo acadêmico e para a sua maior aplicação pelos Tribunais brasileiros. 


\section{BIBLIOGRAFIA}

AGUIAR JR., Ruy Rosado. Extinção dos contratos por incumprimento do devedor (resolução). Rio de Janeiro: Aide. 1991.

AGUIAR JÚNIOR, Ruy Rosado de. Cláusulas abusivas no Código do Consumidor. In: MARQUES, Cláudia Lima (Coord.). Estudos sobre a proteção do consumidor no Brasil e no Mercosul. Livraria. Editora do Advogado.

ALMEIDA COSTA, Mário Júlio. Direito das obrigações. 9. ed. Coimbra: Almedina. 2001 .

ALVES, Jones Figueirêdo. A teoria do adimplemento substancial ("substancial performance") do negócio jurídico como elemento impediente ao direito de resolução do contrato. In: DELGADO, Mário Luiz; ALVES, Jones Figueirêdo (Coord.). Questões controvertidas no direito das obrigações e dos contratos. Série Grandes Temas de Direito Privado. v. 4. São Paulo: Editora Método. 2005.

ALVES, José Carlos Moreira Alves. Direito romano. 14. ed. Rio de Janeiro: Editora Forense. 2007.

ALVIM, Agostinho. Da inexecução das obrigações e suas consequências. 3. ed. atual. Rio de Janeiro: Editora Jurídica e Universitária Ltda. 1949.

AMORIM FILHO, Agnelo. Critério Científico para Distinguir a Prescrição da Decadência e para Identificar ações Imprescritíveis. Revista dos Tribunais, n. 744, 1997.

ANDRADE, Luis Tomás Alves de. O Inadimplemento Antecipado do Contrato no Direito Brasileiro. R. EMERJ, Rio de Janeiro, v. 14, n. 56, p. 145-172, out-dez. 2011.

ASSIS, Araken de. Resolução do contrato por inadimplemento. 4. ed. rev. e atual. São Paulo: Editora Revista dos Tribunais. 2004. 
ATIYAH, P. S.. An introduction to the law of contract. Third Edition. Clarendon Law Series. Oxford: Oxford University Press. 1981.

AZEVEDO, Álvaro Villaça. Teoria geral das obrigações: responsabilidade civil. 10. ed. São Paulo: Atlas. 2004.

AZEVEDO, Antonio Junqueira de. Insuficiências, deficiências e desatualização do projeto de Código Civil na questão da boa-fé objetiva nos contratos, $R T, 775 / 11$.

AZEVEDO, Antonio Junqueira. Negócio jurídico e declaração negocial: noções gerais e formação de declaração negocial. Tese apresentada para obtenção de título de professor titular da Universidade de Direito do Largo São Francisco. São Paulo. 1986.

AZEVEDO, Fábio de Oliveira. Algumas questões de direito civil e de direito processual civil sobre o contrato preliminar. In: HIRONAKA, Giselda Maria Fernandes Novaes; TARTUCE, Flávio (Coord.). Direito contratual. Temas Atuais. São Paulo: Método. 2007.

AZULAY, Fortunato. Do inadimplemento antecipado do contrato. Rio de Janeiro: Editora Brasília/Rio. 1977.

BAREA, Margarita. BECKER, Anelise. A doutrina do adimplemento substancial no direito brasileiro e em perspectiva comparativista. Revista da Faculdade de Direito UFRGS, v. 9, Porto Alegre, Universidade Federal do Rio Grande do Sul, nov. 1993.

BAREA, Margarita. La imposibilidad de cumplir los contratos. LAEL: Dykinson. 2000.

BECKER, Anelise. Inadimplemento antecipado do contrato. Revista de Direito do Consumidor, São Paulo: Revista dos Tribunais, n. 12, 1994.

BEVILAQUA, Clovis. Direito das obrigações. Campinas: Red Livros. 2000. 
BUSSATA, Eduardo Luiz. Resolução dos contratos e teoria do adimplemento substancial. São Paulo: Saraiva. 2007.

CALIXTO, Marcelo Junqueira. Reflexões em torno do conceito de obrigação, seus elementos e suas fontes. In: TEPEDINO, Gustavo (Coord.). Obrigações: estudos na perspectiva civil-constitucional. Rio de Janeiro: Renovar. 2005.

CARVALHO SANTOS, J. M. de. Código Civil brasileiro interpretado. v. XII, 8. ed, Rio de Janeiro: Livraria Freita Bastos. 1963.

CATALAN, Marcos Jorge. Descumprimento contratual. Curitiba: Juruá. 2005.

CATALAN, Marcos Jorge. Reflexões sobre o inadimplemento inexato da obrigação no direito contratual. In: HIRONAKA, Giselda Maria Fernandes Novaes; TARTUCE, Flávio (Coord.). Direito Contratual. Temas Atuais. São Paulo: Método. 2007.

CHAVES, Antonio. Tratado de direito civil. v. 2. tomo 1. São Paulo: Revista dos Tribunais. 1982.

CORBIN, Arthur Linton. Corbin on Contracts. New Haven: West Publishing Co. 1952.

COSTA, Judith Martins. A boa-fé no direito privado. São Paulo: Ed. Revista dos Tribunais.

COSTA, Judith Martins. O fenômeno da supracontratualidade e o princípio do equilíbrio: inadimplemento de deveres de proteção (violação positiva do contrato) e deslealdade contratual em operação de descruzamento acionário. Revista Trimestral de Direito Civil, Rio de Janeiro, n. 26, abr./jun. 2006.

COSTA, Judith Martins. Sistema e cláusula geral: a boa-fé objetiva no processo obrigacional. Tese (doutorado). Faculdade de Direito. São Paulo: USP. 1996. 
DIAS, Daniel Pires Novais. $O$ duty to mitigate the loss no direito civil brasileiro e o encargo de evitar o próprio dano. Disponível em: $<$ http://www.revistas.unifacs.br/index.php/redu/article/view/1894>. Acesso em: 02 jun. 2013.

DIDIER JR., Fredie; CUNHA, Leonardo Carneiro da; BRAGA, Paula Sarno; OLIVEIRA, Rafael Alexandria de. Curso de direito processual civil 5. 6. ed. Salvador: Editora JusPodivm. 2014.

DIEZ-PICAZO, Luis; GULLON, Antonio. Sistema de derecho civil. v. II. Editorial Tecnos: Madrid. 1978.

DUARTE, Adriana Dardengo. A quebra do contrato por repúdio antecipado no direito brasileiro: proposta de aplicação de uma teoria. Dissertação apresentada ao curso de mestrado da Universidade Federal de Minas Gerais. 2006.

FACCHINI NETO, Eugênio. A revitalização do direito privado brasileiro a partir do Código de Defesa do Consumidor. In: LOTUFO, Renan; MARTINS, Fernando Rodrigues (Coord.). 20 anos do Código de Defesa do Consumidor: conquistas, desafios e perspectivas. São Paulo: Saraiva. 2011.

FACHIN, Luiz Edson. Teoria crítica do direito civil à luz do novo Código Civil brasileiro. 2. ed. rev. e atual. Rio de Janeiro: Renovar. 2003.

FARIAS, Cristiano Chaves de; ROSENVALD, Nelson. Curso de direito civil 1. 11. ed. Salvador: Editora JusPodivm. 2013.

FONSECA, Arnoldo Medeiros da. Caso fortuito e teoria da imprevisão. 3. ed. Rio de Janeiro: Forense. 1958. p. 147-148.

FRADERA, Véra Jacob de. A quebra positiva do contrato. Porto Alegre: Ajuris. v. 44. p. 150. nov. 1988. 
FRADERA, Véra Maria Jacob de Fradera. O Conceito de Inadimplemento Fundamental do Contrato no Artigo 25 da Lei Fundamental do Contrato no Artigo 25 da Lei Internacional sobre Vendas, da Convenção de Viena de 1980. Direito, Estado e Sociedade, Rio de Janeiro, n. 9, ago./dez. 1996.

FRADERA, Véra Maria Jacob de. Pode o Credor ser Instado a Diminuir o Próprio Prejuízo? Revista Trimestral de Direito Civil, Rio de Janeiro, n. 19, jul./set. 2004.

FURTADO, Gabriel Rocha. Mora e inadimplemento substancial. São Paulo: Atlas. 2014.

GODOY, Claudio Luiz Bueno de. Função social do contrato: os novos paradigmas contratuais. São Paulo: Saraiva. 2004.

GODOY, Claudio Luiz Bueno de. Responsabilidade civil pelo risco da atividade: uma cláusula geral no Código Civil de 2002. 2. ed. São Paulo: Saraiva. 2010.

GODOY, Claudio Luiz Bueno de. Vícios do produto e do serviço. In: LOTUFO, Renan; MARTINS, Fernando Rodrigues (Coord.). 20 anos do Código de Defesa do Consumidor: conquistas, desafios e perspectivas. São Paulo: Saraiva. 2011.

GOMES, Orlando. Contratos. Rio de Janeiro: Forense. 2008.

GOMES, Orlando. Obrigações. 16. ed. rev., atual. e aum., de acordo com o Código Civil de 2002, por Edvaldo Brito. Rio de Janeiro: Forense. 2005.

GONÇALVES, Carlos Roberto. Direito civil brasileiro. v. 2. Teoria geral das obrigações. 8. ed. São Paulo: Saraiva. 2011.

GONÇALVES, Carlos Roberto. Direito civil brasileiro. v. 3. Contratos e atos unilaterais. 9. Ed. São Paulo: Saraiva. 2012. 
HIRONAKA, Giselda Maria Fernandes Novaes; TARTUCE, Flavio. O princípio da autonomia privada e o direito contratual clássico. In: HIRONAKA, Giselda Maria Fernandes Novaes; TARTUCE, Flávio (Coord.). Direito Contratual. Temas Atuais. São Paulo: Método. 2007.

HIRONAKA, Giselda Maria Fernandes Novaes. Direito das obrigações: o caráter de permanência dos seus institutos, as alterações produzidas pela lei civil brasileira de 2002 e a tutela das futuras gerações. In: DELGADO, Mário Luiz; ALVES, Jones Figueirêdo (Coord.). Série Grandes Temas de Direito Privado. v. 4. São Paulo: Editora Método. 2005.

HIRONAKA, Giselda Mari Fernandes Novaes. Responsabilidade pressuposta. Belo Horizonte: Del Rey, 2005.

KONDER, Carlos Nelson; RENTERÍA, Pablo. A funcionalização das relações obrigacionais: interesse do credor e patrimonialidade da prestação. In: TEPEDINO, Gustavo; FACHIN, Luiz Edson (Org.). Diálogos sobre direito civil. v. II, Rio de Janeiro: Renovar. 2007.

LABOURIAU, Miguel. Algumas considerações sobre o inadimplemento antecipado no direito brasileiro. Revista Trimestral de Direito Civil, v. 42, abr./jun. 2010, Padma, Rio de Janeiro.

LACERDA DE ALMEIDA, Francisco de Paula. Obrigações. 2. ed. Rio de Janeiro: Revista dos Tribunais. 1916.

LARENZ, Karl. Derecho de obligaciones. Trad. de Jaime Santos Briz. t. 1. Madrid: Editorial Revista de Derecho Privado. 1958.

LEAL, Adisson. Violação Positiva dos Contratos. In: ANDRIGHI, Fátima Nancy (Coord.). Responsabilidade civil e inadimplemento no direito brasileiro. São Paulo: Atlas. 2014.

LÔBO, Paulo. Direito civil: obrigações. 3. ed. São Paulo: Saraiva. 2013. 
LUNARDI, Fabrício Castagna. A teoria do abuso de direito e as novas formas de inadimplemento das obrigações: perspectivas atuais à luz da constitucionalização do direito civil. In: ANDRIGHI, Fátima Nancy (Coord.). Responsabilidade civil e inadimplemento no direito brasileiro. São Paulo: Atlas. 2014.

MARINANGELO, Rafael. Aspectos Relevantes da Prescrição e Decadência e o Novo Código Civil. In: NANNI, Giovanni Ettore (Coord.). Temas relevantes do direito civil contemporâneo: reflexões sobre os cinco anos do Código Civil. São Paulo: Atlas. 2008.

MARQUES, Cláudia Lima. Contratos no Código de Defesa do Consumidor. São Paulo: Ed. Revista dos Tribunais, 3. ed.. $2^{\mathrm{a}}$ tiragem.

MARTINEZ, Pedro Romano. Da cessação do contrato. 2. ed. Coimbra: Almedina. 2006.

MARTINS, Raphael Manhães. Inadimplemento antecipado: perspectiva para a sua aplicação no Direito brasileiro. Revista Forense, Rio de Janeiro, v. 391, ano 103, mai./jun. 2007.

MARTINS. Guilherme Magalhães. Inadimplemento antecipado do contrato. Revista Trimestral de Direito Civil, Rio de Janeiro, v. 36, out/dez 2008.

MARTINS-COSTA, Judith. A recepção do incumprimento antecipado no direito brasileiro: configurações e limites. Revista dos Tribunais, v. 885.

MARTINS-COSTA, Judith. Comentários ao novo Código Civil. Rio de Janeiro: Forense. 2004.

MENEZES CORDEIRO, António. Da boa fé no direito civil. Coimbra: Almedina. 2011.

MENEZES CORDEIRO, António. Direito das obrigações. v. I. reimp. 1980. Lisboa: Associação Acadêmica da Faculdade de Direito de Lisboa. 2001. 
MIRANDA, Pontes de. Tratado de direito privado. t. XXVI. Rio de Janeiro: Editor Borsoi. 1959.

MONTEIRO, Washington de Barros. Curso de direito civil. Direito das obrigações. $2^{\mathrm{a}}$ parte: dos contratos em geral, das várias espécies de contrato, dos atos unilaterais, da responsabilidade civil. MONTEIRO, Washington de Barros; MALUF, Carlos Alberto Dabus; SILVA, Regina Beatriz Tavares. 36. ed. São Paulo: Saraiva. 2009.

MORAES, Maria Celina Bodin de. Notas sobre a Promessa de Doação. Revista Trimestral de Direito Civil. Rio de Janeiro, n. 21, jan./mar. 2005.

MOSCO, Luigi. La risoluzione del contrato per inadempimento. Eugenio Jovene: Napoli. 1950.

MOTTA PINTO, Carlos Alberto da. Cessão de contrato. São Paulo: Saraiva. 1985.

NANNI, Giovanni Ettore. O dever de cooperação nas relações obrigacionais à luz do princípio constitucional da solidariedade. In: NANNI, Giovanni Ettore (Coord.). Temas relevantes do direito civil contemporâneo: reflexões sobre os cinco anos do Código Civil. São Paulo: Atlas. 2008.

NEIRA, Lilian C. San Martín. Sobre la naturaleza jurídica de la 'cooperación' del acreedor al cumplimiento de la obligación. La posición dinámica del acreedor en la relación obligatoria, como sujeto no sólo de derechos, sino también de cargas y deberes. Revista de Derecho Privado, $\mathrm{n}^{\mathrm{o}}$ 21, p. 208-282, Julio-Diciembre, 2011. Disponível em: <http://ssrn.com/abstract=1964700. p. 289.L〉. Acesso em: 10 nov. 2014.

NERY JUNIOR, Nelson. Contratos no Código Civil - Apontamentos gerais. In: FRANCIULLI NETTO, Domingos; MENDES, Gilmar Ferreira; MARTINS FILHO, Ives Gandra da Silva (Coord.). O novo Código Civil: estudos em homenagem ao Professor Miguel Reale. São Paulo: LTr. 2003. 
NEVES, José Roberto de Castro. As Garantias do Cumprimento da Obrigação. Revista da EMERJ, v. 11, n 44, 2008.

NEVES, José Roberto de Castro. O Direito das obrigações. Rio de Janeiro: GZ. 2008.

NICOLAU, Gustavo Rene. Implicações Práticas da boa-fé objetiva. In: HIRONAKA, Giselda Maria Fernandes Novaes; TARTUCE, Flávio (Coord.). Direito contratual. Temas Atuais. São Paulo: Método. 2007.

NICOLÒ, Rosario. Adempimento (diritto civile). Enciclopedia del diritto. v. I. Varese: Giuffrè.

NONATO, Orosimbo. Curso de obrigações. v. I. Rio de Janeiro: Forense. 1959.

NORONHA, Fernando. Direito das obrigações. v. I. São Paulo: Saraiva. 2013.

NORONHA, Fernando. O direito dos contratos e os princípios fundamentais: autonomia privada, boa-fé, justiça contratual. São Paulo: Saraiva. 1994.

OLIVEIRA, James Eduardo de. Inadimplemento relativo e inadimplemento absoluto. In: ANDRIGHI, Fátima Nancy (Coord.). Responsabilidade civil e inadimplemento no direito brasileiro. São Paulo: Atlas. 2014.

OLIVEIRA, Ubirajara Mach de. Quebra positiva do contrato. Revista de Direito do Consumidor. v. 25, jan. 1998.

PEIXOTO, Alessandra Cristina Tufvesson. Responsabilidade extracontratual - Algumas considerações sobre a participação da vítima na quantificação da indenização. Revista da Emerj, v.11, n. 44, 2008. 
PEREIRA JUNIOR, Jessé Torres. Comentários à Lei de Licitações e Contratações da Administração Pública. 7. ed. atual e ampl. Rio de Janeiro: Renovar. 2007.

PEREIRA, Caio Mário da Silva. Instituições de Direito Civil. v. I. 21. ed. Rio de Janeiro: Forense. 2005.

PEREIRA, Caio Mário da Silva. Instituições de Direito Civil. vol. II. 20. ed. Rio de Janeiro: Forense, 2005.

PEREIRA, Caio Mario da Silva. Instituições de Direito Civil. v. III. Rio de Janeiro: Forense. 2006.

PERLINGIERI, PIETRO. O direito civil na legalidade constitucional. Trad. de Maria Cristina De Cicco. Rio de Janeiro: Renovar. 2008.

PERLINGIERI. Il fenomeno dell'estinzione nelle obbligazioni. Napoli: ESI. 2004.

PERLINGIERI. Manuale di diritto civile. Napoli: ESI. 1997.

PIZARRO, Ramón Daniel; VALLESPINOS, Carlos Gustavo. Instituciones de derecho privado. Obligaciones 2. Buenos Aires: Editorial Hammurabi SRL. 1999.

PONTES DE MIRANDA, Francisco Cavalcanti. Tratado de direito privado. tomo XXIII. São Paulo: Editora Revista dos Tribunais.

RAMELLA, Anteo E. La Resolución por Incumplimiento. Editoral Astrea: Buenos Aires, 1975 .

RODRIGUES, Silvio. Direito civil. v. 2. 30. ed. São Paulo: Saraiva. 2002.

ROPPO, Enzo. O contrato. Trad. de Ana Coimbra e M. Januário C. Gomes. Coimbra: Livraria Almedina. 1988. 
ROSENVALD, Nelson. Código Civil Comentado. PELUSO, Cezar (Coord.). Manoele: Barueri, SP. 2007.

SALLES, Raquel Bellini de Oliveira Salles. O desequilíbrio da relação obrigacional e a revisão dos contratos no Código de Defesa do Consumidor: para um cotejo com o Código Civil. In: TEPEDINO, Gustavo (Coord.). Obrigações: estudos na perspectiva civilconstitucional. Rio de Janeiro: Renovar. 2005.

SAVI, Sérgio. Inadimplemento das Obrigações, Mora e Perdas e Danos. In: TEPEDINO, Gustavo (Coord.). Obrigações: estudos na perspectiva civil-constitucional. Rio de Janeiro: Renovar. 2005.

SCHLABENDORFF, Adriana. A reconstrução do direito contratual: o valor social do contrato. Tese de Mestrado. Junho de 2004.

SCHREIBER, Anderson. A Boa-fé objetiva e o Adimplemento Substancial. In: HIRONAKA, Giselda Maria Fernandes Novaes; TARTUCE, Flávio (Coord.). Direito Contratual. Temas Atuais. São Paulo: Método. 2007.

SCHREIBER, Anderson. A tríplice transformação do adimplemento. Adimplemento substancial, inadimplemento antecipado e outras figuras. Revista Trimestral de Direito Civil. Rio de Janeiro, v. 32, out./dez 2007.

SCHREIBER, Anderson. Novos paradigmas da responsabilidade civil. São Paulo: Atlas. 2007.

SERPA LOPES, Miguel Maria de. Curso de direito civil. Atualização de José Serpa Santa Maria. 4. ed. rev. e atual. Rio de Janeiro: Freitas Bastos. 1991. v.3.

SERPA LOPES, Miguel Maria. Exceções substanciais: exceção de contrato não cumprido (exceptio non adimpleti contractus). Rio de Janeiro: Freitas Bastos. 1959. 
SILVA, Clóvis do Couto e. A obrigação como processo. Rio de Janeiro: Editora FGV. 2006

SILVA, Clóvis do Couto e. O Princípio da Boa-fé no Direito Brasileiro e no Direito Português. CAETANO, Marcello et al. Estudos de direito civil brasileiro e português (I Jornada luso-brasileira de direito civil). São Paulo: Revista dos Tribunais. 1980. p. 47.

SILVA, De Plácido e. Vocabulário Jurídico. 26. ed. Rio de Janeiro: Editora Forense. 2005.

SILVA, João Calvão da. Cumprimento e sanção pecuniária compulsória. Coimbra: Livraria dos Advogados Editora. 1987.

SILVA, Jorge Cesa Ferreira da. A boa-fé e a violação positiva do contrato. Rio de Janeiro: Renovar. 2002.

SILVA, Jorge Cesa Ferreira da. Adimplemento e extinção das obrigações. São Paulo: Editora Revista dos Tribunais. 2007.

SILVA, Jorge Cesa Ferreira da. Inadimplemento das obrigações. São Paulo: Editora Revista dos Tribunais. 2007.

SIMÃO, José Fernando. Prescrição e decadência: início dos prazos. São Paulo: Atlas. 2013

SOMBRA, Thiago Luís Santos. Adimplemento contratual e colaboração do credor. São Paulo: Saraiva. 2011.

SCHLECHTRIEM, Peter; SCHWENZER, Ingeborg. Comentários à Convenção das Nações Unidas sobre Contratos de Compra e Venda Internacional de Mercadorias. Coordenação de tradução de Eduardo Grebler, Vera Fradera, César Guimarães Pereira. São Paulo: Editora Revista dos Tribunais. 2014. 
STAUB, Hermann. Le violazioni positive del contrato. Tradução de Giovanni Varanese. Napoli: ESI. 2001.

SZTAJN, Rachel. Externalidades e custos de transação: a redistribuição de direitos no Código Civil. Revista de Direito Mercantil, Industrial, Econômico e Financeiro, São Paulo, v. 43, n. 133, p. 7-31, jan./mar. 2004.

TARTUCE, Flávio. A boa-fé e a mitigação do prejuízo pelo credor. Esboço do tema e primeira abordagem. Março de 2005. Disponível em: 〈www.flaviotartuce.adv.br/secoes/artigos/Tartuce_duty.doc $>$. Acesso em: 30 jun. 2013.

TELLES, Inocêncio Galvão. Direito das obrigações. 4. ed. Lisboa: Coimbra Ed. 1982.

TEPEDINO, Gustavo; SCHREIBER, Anderson. A Boa-fé Objetiva no Código de Defesa do Consumidor e no Novo Código Civil. In: TEPEDINO, Gustavo. Obrigações: estudos na perspectiva civil-constitucional. Rio de Janeiro: Renovar. 2005.

TEPEDINO, Gustavo; BARBOZA, Heloisa Helena; MORAES, Maria Celina Bodin de. Código Civil interpretado conforme a Constituição da República. v. I, 2. ed. rev. e atual. Rio de Janeiro: Renovar. 2007.

TEPEDINO, Gustavo; SCHREIBER, Anderson. In: AZEVEDO, Álvaro Villaça (Coord.). Código Civil comentado: direito das obrigações. São Paulo: Atlas. 2008.

TEPEDINO, Gustavo. Novos princípios contratuais e teoria da confiança: a exegese da cláusula to the best knowledge of the sellers. Temas de direito civil. Rio de Janeiro: Renovar. 2006. t. II.

TERRA, Aline de Miranda Valverde. Inadimplemento anterior ao termo. Rio de Janeiro: Renovar. 2009. 
THEODORO JUNIOR, Humberto. A reforma da execução do título extrajudicial: Lei ${ }^{\circ}$ 11.382, de 06 de dezembro de 2006. Rio de Janeiro: Forense. 2007.

TRABUCCHI, Alberto. Istituzioni di Diritto Civile. Trentesima nona edizione aggiornata com le riforme e la giurisprudenza.Pádua: Cedam. 1999.

TREVISAN, Marco Antonio. Responsabilidade civil pós-contratual. Revista de Direito Privado, v. 2, p. 259. out/2011.

VARELA, João de Mattos Antunes. Das obrigações em geral. Coimbra: Almedina. 1970.

VILLELA, João Baptista et al. Princípios UNIDROIT relativos aos Contratos Comerciais Internacionais/2004 [versão em língua portuguesa]. São Paulo: Quartier Latin. 2009.

VILLELA, João Baptista. Sanção por inadimplemento contratual antecipado: subsídios para uma teoria intersistemática das obrigações. Belo Horizonte. 1966.

VILUS, JELENA. Provisions common to the obligations of the seller and the buyer. In: International Sale of Goods. Dubrovnik Lectures. Oceana Publications. 1986.

WASHOFSKY, Leonard. A. Contracts - Anticipatory Breach - Specific Performance. Tulane Law Review, v. XXXIII, 1959.

ZANETTI, Cristiano de Souza. Exceção de Contrato não Cumprido. In: MORRIS, Amanda Zoe; BARROSO, Lucas Abreu (Coord.). Direito dos contratos. Orientação de Giselda M. F. Novaes Hironaka. São Paulo: Editora Revista dos Tribunais. 2008.

ZANETTI, Cristiano de Souza. Inadimplemento Antecipado da Obrigação Contratual. In: CELLI JUNIOR, Umberto; BASSO, Maristela; AMARAL JÚNIOR, Alberto do (Coord). Arbitragem e comércio internacional: estudos em homenagem a Luiz Olavo Baptista. São Paulo: Quartier Latin. 2013. 
ZANETTI, Cristiano de Souza. A Mitigação do Dano e Alocação da Responsabilidade. Revista Brasileira de Arbitragem, nº 35, jul/set 2012. 